to

\title{
Synthesis of Trans-Isotactic Poly(Norbornene)s Through Living Ring-Opening Metathesis Polymerization Initiated by Group VI Imido Alkylidene N- Heterocyclic Carbene Complexes
}

Mathis J. Benedikter, Roman Schowner, Iris Elser, Philipp Werner, Katharina Herz, Laura

Stöhr, Dominik A. Imbrich, Gergely M. Nagy, Dongren Wang, Michael R. Buchmeiser*

\section{Experimental Details}

\section{Initiator Synthesis}

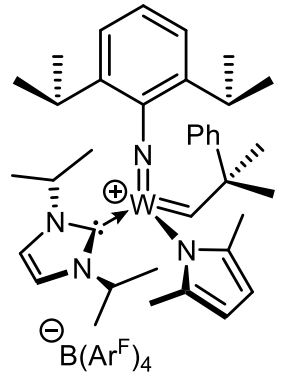

17

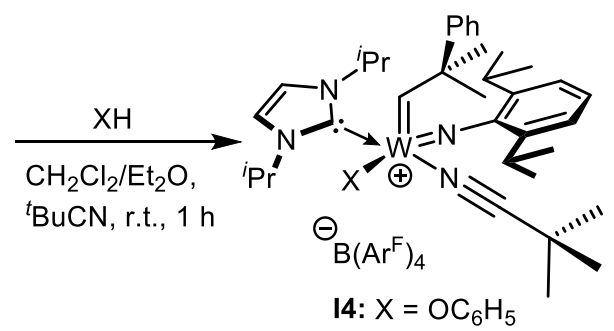

15: $\mathrm{X}=\mathrm{OC}\left(\mathrm{CF}_{3}\right)_{3}$

Scheme S 1: Synthesis route for initiators $\mathbf{I 4}$ and $\mathbf{I 5 .}$

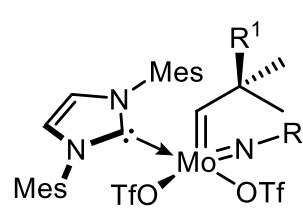

18: $\mathrm{R}=2-{ }^{t} \mathrm{BuC}_{6} \mathrm{H}_{4} ; \mathrm{R}^{1}=\mathrm{Ph}$ 19: $\mathrm{R}=2,6-\mathrm{Me}_{2} \mathrm{C}_{6} \mathrm{H}_{3} ; \mathrm{R}^{1}=\mathrm{Ph}$ I10: $\mathrm{R}=3,5-\mathrm{Me}_{2} \mathrm{C}_{6} \mathrm{H}_{3} ; \mathrm{R}^{1}=\mathrm{Ph}$ I11: $\mathrm{R}=2,6-\mathrm{Cl}_{2} \mathrm{C}_{6} \mathrm{H}_{3} ; \mathrm{R}^{1}=\mathrm{Me}$ I12: $\mathrm{R}=2-\mathrm{CF}_{3} \mathrm{C}_{6} \mathrm{H}_{4} ; \mathrm{R}^{1}=\mathrm{Ph}$ I13: $\mathrm{R}={ }^{t} \mathrm{Bu} ; \mathrm{R}^{1}=\mathrm{Ph}$ I14: $\mathrm{R}=\mathrm{Ad} ; \mathrm{R}^{1}=\mathrm{Ph}$

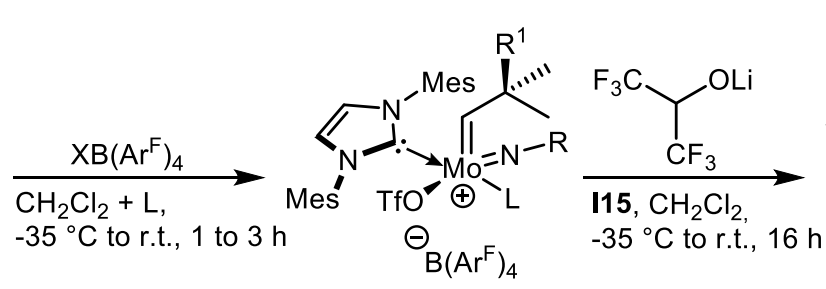
I15: $\mathrm{R}=2{ }^{-}{ }^{-} \mathrm{BuC}_{6} \mathrm{H}_{4} ; \mathrm{R}^{1}=\mathrm{Ph} ; \mathrm{L}=$ none; $\mathrm{X}=\mathrm{Na}$ I15-MeCN: $\mathrm{R}=2-{ }^{t} \mathrm{BuC}_{6} \mathrm{H}_{4} ; \mathrm{R}^{1}=\mathrm{Ph} ; \mathrm{L}=\mathrm{MeCN} ; \mathrm{X}=\mathrm{Na}$ I16: $\mathrm{R}=2,6-\mathrm{Me}_{2} \mathrm{C}_{6} \mathrm{H}_{3} ; \mathrm{R}^{1}=\mathrm{Ph} ; \mathrm{L}=\mathrm{MeCN} ; \mathrm{X}=\mathrm{Na}$

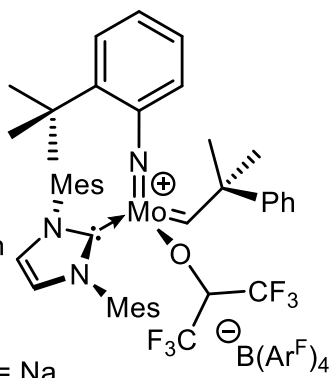
I17: $\mathrm{R}=3,5-\mathrm{Me}_{2} \mathrm{C}_{6} \mathrm{H}_{3} ; \mathrm{R}^{1}=\mathrm{Ph} ; \mathrm{L}=\mathrm{MeCN} ; \mathrm{X}=\mathrm{Na}$ 118: $R=2,6-\mathrm{Cl}_{2} \mathrm{C}_{6} \mathrm{H}_{3} ; \mathrm{R}^{1}=\mathrm{Me} ; \mathrm{L}=$ none; $X=\mathrm{Na}$ I19: $\mathrm{R}=2-\mathrm{CF}_{3} \mathrm{C}_{6} \mathrm{H}_{4} ; \mathrm{R}^{1}=\mathrm{Ph} ; \mathrm{L}=$ none; $\mathrm{X}=\mathrm{TI}$ I20: $\mathrm{R}={ }^{t} \mathrm{Bu} ; \mathrm{R}^{1}=\mathrm{Ph} ; \mathrm{L}=\mathrm{MeCN} ; \mathrm{X}=\mathrm{Na}$

Scheme S 2: Synthesis route for initiators $\mathbf{1 8}$ to $\mathbf{I 2 1 .}$ 

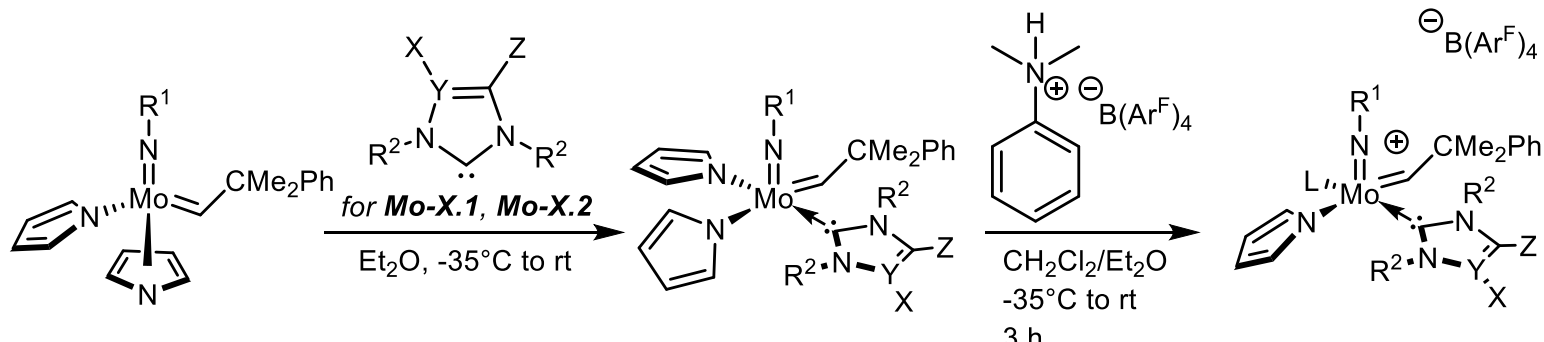
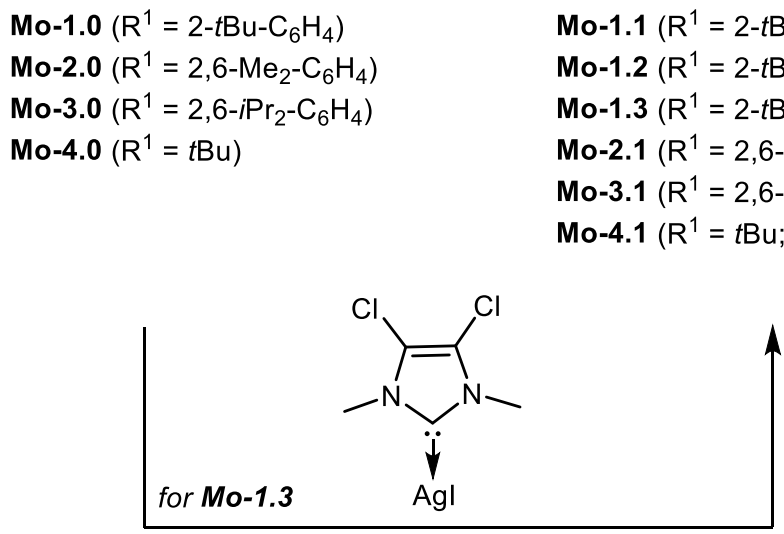

$\mathrm{CH}_{2} \mathrm{Cl}_{2},-35^{\circ} \mathrm{C}$ to rt

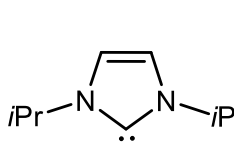

NHC-1<smiles></smiles>

NHC-2<smiles>CN1CN(C)C(Cl)=C1Cl</smiles>

NHC-3

\begin{abstract}
$124\left(\mathrm{R}^{1}=2-\mathrm{tBu}^{-\mathrm{C}_{6}} \mathrm{H}_{4} ; \mathrm{NHC}-1\right)$ $126\left(\mathrm{R}^{1}=2-\mathrm{tBu}^{-\mathrm{C}_{6}} \mathrm{H}_{4} ; \mathrm{NHC}-2\right)$ $127\left(\mathrm{R}^{1}=2-\mathrm{tBu}^{-\mathrm{C}_{6}} \mathrm{H}_{4} ; \mathrm{NHC}-3\right)$ $122\left(\mathrm{R}^{1}=2,6-\mathrm{Me}_{2}-\mathrm{C}_{6} \mathrm{H}_{3} ; \mathrm{NHC}-1\right)$ I25 $\left(\mathrm{R}^{1}=2,6-\mathrm{Prr}_{2}-\mathrm{C}_{6} \mathrm{H}_{3} ; \mathrm{NHC}-\mathbf{1}\right)$ I23 $\left(\mathrm{R}^{1}=t \mathrm{Bu} ;\right.$ NHC-1)
\end{abstract}

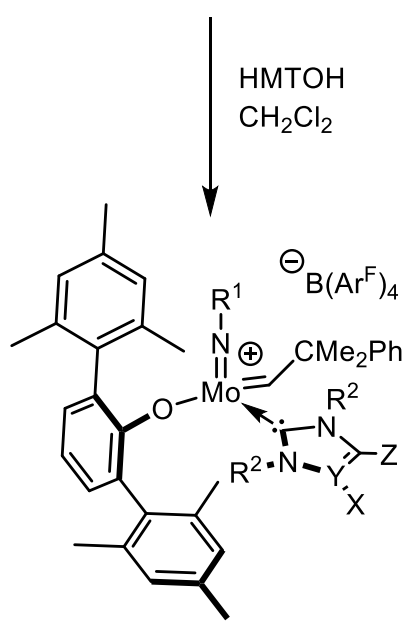

$128\left(\mathrm{R}^{1}=2-t \mathrm{Bu}-\mathrm{C}_{6} \mathrm{H}_{4} ; \mathrm{NHC}-1\right)$

I29 $\left(\mathrm{R}^{1}=2,6-\mathrm{Me}_{2}-\mathrm{C}_{6} \mathrm{H}_{3} ;\right.$ NHC-1 $)$

Scheme S 3: Synthesis route for Initiators $\mathbf{I 2 2}$ to $\mathbf{I 2 9 .}$

General Information: Unless stated otherwise, all reactions were performed under inert gas atmosphere $\left(\mathrm{N}_{2}\right)$, either in a glove box (LabMaster 130, MBraun, Garching, Germany) or with standard Schlenk techniques. Dichloromethane, diethyl ether, toluene, pentane and tetrahydrofuran were dried by a solvent purification system (SPS, MBraun). NMR measurements were recorded on a Bruker Avance III 400. Chemical shifts are reported in ppm relative to the solvent signal; coupling constants are listed in Hz. Starting materials and reagents were purchased from Merck (Munich, Germany), Alfa Aesar (Karlsruhe, Germany), or ABCR (Karlsruhe, Germany) and were used as received unless stated otherwise. $\mathrm{Mo}(\mathrm{NR})\left(\mathrm{CHCMe}_{2} \mathrm{Ph}\right)(\mathrm{OTf})_{2}(\mathrm{DME})$ complexes $^{[1]}$ (DME = 1,2-dimethoxyethane, $\mathrm{R}=2$ - $t \mathrm{Bu}-\mathrm{C}_{6} \mathrm{H}_{4}, 2,6-\mathrm{Pr}_{2}-\mathrm{C}_{6} \mathrm{H}_{3}, 2,6-\mathrm{Me}_{2}-\mathrm{C}_{6} \mathrm{H}_{3}, t \mathrm{Bu}, \mathrm{Ad}$ ), 
$\mathrm{NHC} 1^{[2]}, \mathbf{N H C} 2^{[3]}, \mathrm{NHC} 3 \times\left. A g\right|^{[4]}, 1^{[5]}$ and $2^{[6]}$ were synthesized according to published procedures.

$\left.\left[\mathrm{W}\left(\mathrm{N}-2,6-{ }^{i} \mathrm{Pr}_{2} \mathrm{C}_{6} \mathrm{H}_{3}\right)\left(5^{i} \mathrm{Pr}\right)\left(\mathrm{CHCMe}_{2} \mathrm{Ph}\right)\left(\mathrm{OC}_{6} \mathrm{H}_{5}\right)\right)\left({ }^{t} \mathrm{BuCN}\right)\right]\left[\mathrm{B}\left(\mathrm{Ar}^{\mathrm{F}}\right)_{4}\right]$ (14): A solution of phenol (1.8 mg, $0.02 \mathrm{mmol}, 1$ eq.) in diethyl ether $(2 \mathrm{~mL})$ was added to a solution of $\left.\left[\mathrm{W}\left(\mathrm{N}-2,6^{-}{ }^{-} \mathrm{Pr}_{2} \mathrm{Ph}\right)\left(5^{\mathrm{P} P r}\right)\left(\mathrm{CHCMe}_{2} \mathrm{Ph}\right)\left(\mathrm{Me}_{2} \mathrm{Pyr}\right)\right)\right]\left[\mathrm{B}\left(\mathrm{Ar}^{\mathrm{F}}\right)_{4}\right](\mathbf{I 7}, 30 \mathrm{mg}, 0.02 \mathrm{mmol}, 1$ eq. $)$ in $\mathrm{CH}_{2} \mathrm{Cl}_{2}(4 \mathrm{~mL})$. After stirring for ten minutes at room temperature, five drops of pivalonitrile were added to the solution and the reaction was stirred for one hour at room temperature. The solvent was evaporated in vacuo and the residue was triturated with $n$-pentane. The resulting solid was recrystallized from a mixture of diethyl ether and $n$-pentane to yield pale yellow crystals. Yield: $18.2 \mathrm{mg}, 0.01 \mathrm{mmol}, 58 \%$. ${ }^{1} \mathrm{H}-\mathrm{NMR}$ (CDCl $3,400 \mathrm{MHz}): \delta 13.61$ (s, $0.07 \mathrm{H}$, anti), 12.30 (s, $0.93 \mathrm{H}$, syn), 7.75 (s, 8H), 7.55 $(\mathrm{s}, 4 \mathrm{H}), 7.52-7.45(\mathrm{~m}, 2 \mathrm{H}), 7.41\left(\mathrm{t},{ }^{3} \mathrm{~J}_{\mathrm{HH}}=7.8 \mathrm{~Hz}, 2 \mathrm{H}\right), 7.37-7.24(\mathrm{~m}, 3 \mathrm{H}), 7.20(\mathrm{~s}$, $3 \mathrm{H}), 7.04(\mathrm{~s}, 2 \mathrm{H}), 6.92\left(\mathrm{t},{ }^{3} \mathrm{~J}_{\mathrm{HH}}=7.4 \mathrm{~Hz}, 1 \mathrm{H}\right), 6.67\left(\mathrm{~d}, 3^{3} \underline{\mathrm{HH}}=7.6 \mathrm{~Hz}, 2 \mathrm{H}\right), 4.34$ (hept, $\left.{ }^{3} \mathrm{~J}_{\underline{\mathrm{HH}}}=6.7 \mathrm{~Hz}, 2 \mathrm{H}\right), 3.54$ (hept, $\left.{ }^{3} \mathrm{~J}_{\mathrm{HH}}=7.0 \mathrm{~Hz}, 2 \mathrm{H}\right), 1.94(\mathrm{~s}, 3 \mathrm{H}), 1.74(\mathrm{~s}, 3 \mathrm{H}), 1.36$ (d, $\left.{ }^{3} J_{\underline{H H}}=6.8 \mathrm{~Hz}, 6 \mathrm{H}\right), 1.19\left(\mathrm{~d},{ }^{3} \mathrm{~J}_{\mathrm{HH}}=6.7 \mathrm{~Hz}, 6 \mathrm{H}\right), 1.07(\mathrm{~s}, 9 \mathrm{H}), 0.99\left(\mathrm{~d},{ }^{3} J_{\underline{H H}}=6.6 \mathrm{~Hz}\right.$, $6 \mathrm{H}), 0.84\left(\mathrm{~d},{ }^{3} \mathrm{~J}_{\mathrm{HH}}=6.8 \mathrm{~Hz}, 6 \mathrm{H}\right) .{ }^{19} \mathrm{~F}-\mathrm{NMR}\left(\mathrm{CDCl}_{3}, 376 \mathrm{MHz}\right): \delta-62.34 .{ }^{13} \mathrm{C}-\mathrm{NMR}$ (CDCl $3,101 \mathrm{MHz}): \delta 297.34,185.82,163.28,161.89$ (q, J = 49.8 Hz), 149.89, 147.84, $144.48,134.98,130.11,129.09,129.07\left(q q,{ }^{2} J_{C F}=31.9 \mathrm{~Hz},{ }^{3} J_{C B}=3.1 \mathrm{~Hz}\right), 128.12$, 127.22, 125.74, $124.73\left(\mathrm{q},{ }^{1} \mathrm{~J}_{\mathrm{CF}}=272.5 \mathrm{~Hz}\right), 123.66,121.59,118.53,118.37,117.63$, 54.36, 54.01, 32.16, 30.06, 28.58, 26.87, 24.39, 23.95, 23.55, 22.70. Elemental analysis (\%) calcd. $\mathrm{C}_{74} \mathrm{H}_{71} \mathrm{BF}_{24} \mathrm{~N}_{4} \mathrm{OW}$ : C 52.81, H 4.25, N 3.33; found: C 52.71, H 4.367, N 3.38 .

$\left.\left[\mathrm{W}\left(\mathrm{N}-2,6^{-}{ }^{-} \mathrm{Pr}_{2} \mathrm{C}_{6} \mathrm{H}_{3}\right)\left(5^{\mathrm{i}} \mathrm{Pr}\right)\left(\mathrm{CHCMe}_{2} \mathrm{Ph}\right)\left(\mathrm{OC}\left(\mathrm{CF}_{3}\right)_{3}\right)\right)\left({ }^{\mathrm{B}} \mathrm{BuCN}\right)\right]\left[\mathrm{B}\left(\mathrm{Ar}^{\mathrm{F}}\right)_{4}\right] \quad(\mathrm{I5}): \quad$ The compound was prepared analogously to compound 14 employing nonafluoro-tert- 
butanol (4.5 mg, $0.02 \mathrm{mmol}, 1$ eq.). Yield: $28.9 \mathrm{mg}, 0.02 \mathrm{mmol}, 90 \%$ \% ${ }^{1} \mathrm{H}-\mathrm{NMR}$ $\left(\mathrm{CD}_{2} \mathrm{Cl}_{2}, 400 \mathrm{MHz}\right): \delta 12.53(\mathrm{~s}, 1 \mathrm{H}), 7.72$ (brs, 8H), $7.56(\mathrm{~s}, 4 \mathrm{H}), 7.43(\mathrm{~d}, J=4.3 \mathrm{~Hz}$, 4H), $7.33(\mathrm{~m}, 1 \mathrm{H}), 7.22(\mathrm{~s}, 3 \mathrm{H}), 7.13(\mathrm{~s}, 2 \mathrm{H}), 4.08(\mathrm{~m}, 2 \mathrm{H}), 3.55-3.36(\mathrm{~m}, 2 \mathrm{H}), 1.90$ (s, 3H), $1.69(\mathrm{~s}, 3 \mathrm{H}), 1.45(\mathrm{~s}, 9 \mathrm{H}), 1.39(\mathrm{~d}, J=5.2 \mathrm{~Hz}, 6 \mathrm{H}), 1.31(\mathrm{~m}, 6 \mathrm{H}), 1.06(\mathrm{~m}, 6 \mathrm{H})$, $0.76(\mathrm{~m}, 6 \mathrm{H}) .{ }^{19} \mathrm{~F}-\mathrm{NMR}\left(\mathrm{CD}_{2} \mathrm{Cl}_{2}, 376 \mathrm{MHz}\right):-62.8\left(\mathrm{CF}_{3}\right),-73.5 \mathrm{ppm} .{ }^{13} \mathrm{C}-\mathrm{NMR}\left(\mathrm{CD}_{2} \mathrm{Cl}_{2}\right.$, $101 \mathrm{MHz}): \delta 298.5,185.9,162.4,149.9,147.6,146.8,145.8,137.3,135.4,129.8$, $129.5,129.3,127.9,126.6,125.9,123.9,123.8,121.1,119.4,118.0,86.2,66.3,55.2$, 55.0, 34.7, 32.1, 30.7, 29.9, 29.5, 27.6, 24.4, 23.9, 23.1, 22.9, 14.4. Elemental analysis (\%) calcd. $\mathrm{C}_{72} \mathrm{H}_{66} \mathrm{BF}_{33} \mathrm{~N}_{4} \mathrm{OW}$ : C 47.39, H 3.65, N 3.07; found: C 47.39, H 3.837, N 3.09.

$\left[\mathrm{Mo}\left(\mathrm{N}-2-{ }^{\mathrm{t}} \mathrm{BuC}_{6} \mathrm{H}_{4}\right)(5 \mathrm{Mes})\left(\mathrm{CHCMe}_{2} \mathrm{Ph}\right)(\mathrm{OTf})\right]\left[\mathrm{B}\left(\mathrm{Ar}^{\mathrm{F}}\right)_{4}\right]$ (I15): A cold solution $\left(-35^{\circ} \mathrm{C}\right)$ of $\mathrm{NaB}\left(\mathrm{Ar}^{\mathrm{F}}\right)_{4}(0.19 \mathrm{~g}, 0.22 \mathrm{mmol}, 1 \mathrm{eq})$ in diethyl ether $(3 \mathrm{~mL})$ was slowly added to a cold solution of $\mathrm{Mo}\left(\mathrm{N}-2{ }^{-} \mathrm{BuPh}\right)(5 \mathrm{Mes})\left(\mathrm{CHCMe}_{2} \mathrm{Ph}\right)(\mathrm{OTf})_{2}(\mathbf{I 8}, 0.21 \mathrm{~g}, 0.22 \mathrm{mmol}$, 1 eq. $)$ in $\mathrm{CH}_{2} \mathrm{Cl}_{2}(3 \mathrm{~mL})$. The solution was stirred at room temperature for three hours and the solvent was evaporated. The residue was dissolved in $\mathrm{CH}_{2} \mathrm{Cl}_{2}$ and filtered through a pad of celite. The product was recrystallized from a mixture of $\mathrm{CH}_{2} \mathrm{Cl}_{2}$, diethyl ether and $n$-pentane. Yield: $0.27 \mathrm{~g}, 0.16 \mathrm{mmol}, 73 \% .{ }^{1} \mathrm{H}-\mathrm{NMR}\left(\mathrm{CDCl}_{3}, 400 \mathrm{MHz}\right): \delta 12.83$ (s, 1H), $7.72(\mathrm{~s}, 8 \mathrm{H}), 7.52(\mathrm{~s}, 4 \mathrm{H}), 7.32(\mathrm{~s}, 4 \mathrm{H}), 7.22-7.08(\mathrm{~m}, 4 \mathrm{H}), 7.07-7.01(\mathrm{~m}, 1 \mathrm{H})$, $6.97-6.91(\mathrm{~m}, 2 \mathrm{H}), 6.89(\mathrm{~s}, 2 \mathrm{H}), 6.75(\mathrm{~s}, 2 \mathrm{H}), 2.20(\mathrm{~s}, 6 \mathrm{H}), 2.02(\mathrm{~s}, 6 \mathrm{H}), 1.92(\mathrm{~s}, 6 \mathrm{H})$, $1.55(\mathrm{~s}, 3 \mathrm{H}), 1.20(\mathrm{~s}, 3 \mathrm{H}), 1.15(\mathrm{~s}, 9 \mathrm{H}) .{ }^{19} \mathrm{~F}-\mathrm{NMR}\left(\mathrm{CDCl}_{3}, 376 \mathrm{MHz}\right): \delta-62.40\left(\mathrm{CF}_{3}\right),-$ $73.73\left(\mathrm{CF}_{3} \mathrm{SO}_{3}\right) .{ }^{13} \mathrm{C}-\mathrm{NMR} \quad\left(\mathrm{CDCl}_{3}, \quad 101 \mathrm{MHz}\right): \quad \delta \quad 320.9, \quad 179.5,161.9$ (q, $\left.{ }^{1} J_{\mathrm{BC}}=49.8 \mathrm{~Hz}\right), 154.2,149.5,144.6,142.0,135.0,134.7,134.5,133.2,131.8,130.8$, $130.5,129.0\left(q q,{ }^{2} J_{C F}=34.2 \mathrm{~Hz},{ }^{3} J_{C B}=2.9 \mathrm{~Hz}\right), 128.9,127.7,127.0,126.6,126.1$, 125.6, $124.7\left(q,{ }^{1} J_{\mathrm{CF}}=272.7 \mathrm{~Hz}\right), 117.6,59.6,35.8,31.6,30.4,28.5,21.0,18.0,17.8$. Elemental analysis (\%) calcd. $\mathrm{C}_{74} \mathrm{H}_{63} \mathrm{BF}_{27} \mathrm{MoN}_{3} \mathrm{O}_{4} \mathrm{~S}$ : C 51.97, H 3.71, N 2.46; found: C 51.72, H 3.76, N 2.59. 
[Mo(N-2- $\left.\left.{ }^{\mathrm{B}} \mathrm{BuC}_{6} \mathrm{H}_{4}\right)(5 \mathrm{Mes})\left(\mathrm{CHCMe}_{2} \mathrm{Ph}\right)(\mathrm{MeCN})(\mathrm{OTf})\right]\left[\mathrm{B}\left(\mathrm{ArF}_{4}\right)_{4}\right]$ (I15-MeCN): Complex I15 (0.05 g, $0.03 \mathrm{mmol})$ was dissolved in $\mathrm{CH}_{2} \mathrm{Cl}_{2}(4 \mathrm{~mL})$ and acetonitrile $(0.5 \mathrm{~mL})$ was slowly added. The reaction was stirred at room temperature for three hours and the solvent was removed in vacuo. The product was crystallized from a mixture of $\mathrm{CH}_{2} \mathrm{Cl}_{2}$ and $n$-pentane. Yield: $0.03 \mathrm{~g}, 0.02 \mathrm{mmol}, 73 \%$. ${ }^{1} \mathrm{H}-\mathrm{NMR}\left(\mathrm{CD}_{2} \mathrm{Cl}_{2}, 400 \mathrm{MHz}\right): \delta 13.64$ (s, $\left.1 \mathrm{H}, \mathrm{CHCMe}_{2} \mathrm{Ph},{ }^{1} \mathrm{~J}_{\mathrm{CH}}=123.1 \mathrm{~Hz}\right), 7.72(\mathrm{br} \mathrm{s}, 8 \mathrm{H}), 7.56(\mathrm{~s}, 4 \mathrm{H}), 7.40-7.32(\mathrm{~m}, 2 \mathrm{H})$, 7.29 (s, 2H), 7.27-7.13 (m, 5H), 7.10-7.02 (m, 4H), 6.84 (br s, 2H), 2.29 (s, 6H), 2.20 (s, 6H), 2.01-1.85 (m, 9H), 1.69 (s, 3H), $1.11(\mathrm{~s}, 9 \mathrm{H}), 0.83$ (s, 3H); ${ }^{19} \mathrm{~F}-\mathrm{NMR}\left(\mathrm{CD}_{2} \mathrm{Cl}_{2}\right.$, $376 \mathbf{M H z}$ ): $\delta-62.86\left(\mathrm{~s}, 24 \mathrm{~F}, \mathrm{CF}_{3}\right),-76.18\left(\mathrm{~s}, 3 \mathrm{~F}, \mathrm{CF}_{3} \mathrm{SO}_{3}\right) ;{ }^{13} \mathrm{C}-\mathrm{NMR}\left(\mathrm{CD}_{2} \mathrm{Cl}_{2}\right.$, $101 \mathrm{MHz}$ ): $\delta 327.1$ ( $\mathrm{CHCMe}_{2} \mathrm{Ph}$ ), 181.7 ( $\left.\mathrm{C}_{\mathrm{NHC}}\right), 162.9$ (q, ${ }^{1} \mathrm{~J}_{\mathrm{BC}}=50.1 \mathrm{~Hz}, \mathrm{~B}(\mathrm{ArF})$ ), 153.6, 148.8, 143.6, 141.6, 136.0, 135.8, 135.2, 134.9, 134.3, 131.5, 130.7, 130.4, $129.7,129.4,129.1,129.0,128.8,127.5,127.2,126.6,126.4,123.6,120.9,119.6$ (q, $\left.\mathrm{CF}_{3} \mathrm{SO}_{3}, J=317.9 \mathrm{~Hz}\right), 117.8,59.8,36.1,30.9,29.3,29.0,21.1,18.5,3.3$. Elemental analysis (\%) calcd. $\mathrm{C}_{76} \mathrm{H}_{64} \mathrm{BF}_{27} \mathrm{MoN}_{4} \mathrm{O}_{3} \mathrm{~S}$ : C 52.67, H 3.72, N 3.23; found: C 52.73, H $3.77, \mathrm{~N} 3.36$.

[Mo(N-3,5-Me $\left.\left.{ }_{2} \mathrm{C}_{6} \mathrm{H}_{3}\right)(5 \mathrm{Mes})\left(\mathrm{CHCMe}_{2} \mathrm{Ph}\right)(\mathrm{MeCN})(\mathrm{OTf})\right]\left[\mathrm{B}\left(\mathrm{ArF}_{4}\right)_{4}\right.$ (117): A cold solution $\left(-35^{\circ} \mathrm{C}\right)$ of $\mathrm{Mo}\left(\mathrm{N}-3,5-\mathrm{Me}_{2} \mathrm{C}_{6} \mathrm{H}_{3}\right)(5 \mathrm{Mes})\left(\mathrm{CHCMe}_{2} \mathrm{Ph}\right)(\mathrm{OTf})_{2} \quad($ I10, $0.05 \mathrm{~g}, 0.05 \mathrm{mmol}$, 1 eq.) in $\mathrm{CH}_{2} \mathrm{Cl}_{2}(2 \mathrm{~mL})$ and a few drops of $\mathrm{MeCN}$ was added to a cold suspension of $\mathrm{NaB}\left(\mathrm{Ar}^{\mathrm{F}}\right)_{4}(0.05 \mathrm{~g}, 0.05 \mathrm{mmol}, 1 \mathrm{eq})$ in $\mathrm{CH}_{2} \mathrm{Cl}_{2}(2 \mathrm{~mL})$. The resulting suspension was stirred at room temperature for 30 minutes and the solvent was evaporated. The residue was taken up in $\mathrm{CH}_{2} \mathrm{Cl}_{2}$, filtered through a pad of celite, the solvent was removed again and the residue triturated with $n$-pentane to yield a yellow solid. Yield: $70 \mathrm{mg}, 0.04 \mathrm{mmol} 76 \%$. ${ }^{1} \mathrm{H}$ NMR $\left(\mathrm{CDCl}_{3}, 400 \mathrm{MHz}\right): \delta 13.43$ (s, 1H), 7.69 (s, 8H), $7.50(\mathrm{~s}, 4 \mathrm{H}), 7.24-7.14(\mathrm{~m}, 5 \mathrm{H}), 7.08-7.02(\mathrm{~m}, 3 \mathrm{H}), 7.00(\mathrm{~s}, 1 \mathrm{H}), 6.89(\mathrm{~s}, 2 \mathrm{H}), 6.73$ (s, 2H), $6.55(\mathrm{~s}, 2 \mathrm{H}), 2.22(\mathrm{~s}, 12 \mathrm{H}), 2.02(\mathrm{~s}, 6 \mathrm{H}), 1.99(\mathrm{~s}, 6 \mathrm{H}), 1.80(\mathrm{~s}, 6 \mathrm{H}), 1.15(\mathrm{~s}, 3 \mathrm{H})$. 
${ }^{19} \mathrm{~F} \mathrm{NMR}\left(\mathrm{CDCl}_{3}, 376 \mathrm{MHz}\right): \delta 62.41$ (s, 24F), $76.04\left(\mathrm{~s}, \mathrm{CF}_{3} \mathrm{SO}_{3}\right) .{ }^{13} \mathrm{C} \mathrm{NMR}\left(\mathrm{CDCl}_{3}\right.$, $101 \mathrm{MHz}$ ): $\delta 329.83,183.64,161.83\left(\mathrm{q},{ }^{1} \mathrm{~J}_{\mathrm{BC}}=49.8 \mathrm{~Hz}\right), 153.34,144.54,143.09$, $140.97,138.82,135.72,134.94,134.71,133.62,133.44,130.50,130.00,129.86$, 129.02 (qq, ${ }^{2} J_{C F}=31.8 \mathrm{~Hz},{ }^{3} J_{C B}=2.8 \mathrm{~Hz}$ ), 128.71, 127.02, 126.11, 126.02, 125.52 , $124.69\left(\mathrm{q},{ }^{1} \mathrm{~J}_{\mathrm{CF}}=272.4 \mathrm{~Hz}\right), 117.60,56.14,29.95,29.20,21.04,18.00,17.95,17.01$. Elemental analysis (\%) calcd. $\mathrm{C}_{74} \mathrm{H}_{64} \mathrm{BF}_{27} \mathrm{MoN}_{4} \mathrm{O}_{3} \mathrm{~S}$ : C, 52.00; $\mathrm{H}, 3.77 ; \mathrm{N}, 3.28$; found: C, 51.96; H, 3.946; N, 3.50.

$\left[\mathrm{Mo}\left(\mathrm{N}-2,6-\mathrm{Cl}_{2} \mathrm{C}_{6} \mathrm{H}_{3}\right)(5 \mathrm{Mes})\left(\mathrm{CHCMe}{ }_{2} \mathrm{Ph}\right)(\mathrm{OTf})\right]\left[\mathrm{B}(\mathrm{Ar})_{4}\right]$ (118): A cold solution $\left(-35^{\circ} \mathrm{C}\right)$ of $\mathrm{Mo}\left(\mathrm{N}-2,6-\mathrm{Cl}_{2} \mathrm{Ph}\right)(5 \mathrm{Mes})\left(\mathrm{CHCMe}_{2} \mathrm{Ph}\right)(\mathrm{OTf})_{2}(\mathrm{I11}, 0.20 \mathrm{~g}, 0.22 \mathrm{mmol}, 1$ eq. $)$ in $\mathrm{CH}_{2} \mathrm{Cl}_{2}$ (3 mL) was added to a cold suspension of $\mathrm{NaB}\left(\mathrm{Ar}^{\mathrm{F}}\right)_{4}(0.19 \mathrm{~g}, 0.22 \mathrm{mmol}, 1 \mathrm{eq}) \mathrm{CH}_{2} \mathrm{Cl}_{2}$ $(3 \mathrm{~mL})$. The resulting suspension was stirred at room temperature for three hours, filtered through a pad of celite and the solvent was evaporated. The product was recrystallized from a mixture of $\mathrm{CH}_{2} \mathrm{Cl}_{2}$, diethyl ether and $n$-pentane. Yield: $0.28 \mathrm{~g}$, $0.17 \mathrm{mmol}, 79$ \%. ${ }^{1} \mathrm{H}-\mathrm{NMR}\left(\mathrm{CDCl}_{3}, 400 \mathrm{MHz}\right): \delta 12.59$ (s, 1H), $7.72(\mathrm{~s}, 8 \mathrm{H}), 7.52$ (s, 4H), $7.39(\mathrm{~s}, 2 \mathrm{H}), 7.30-7.15(\mathrm{~m}, 3 \mathrm{H}), 6.97(\mathrm{~s}, 2 \mathrm{H}), 6.82(\mathrm{~s}, 2 \mathrm{H}), 2.20(\mathrm{~s}, 6 \mathrm{H}), 2.02(\mathrm{~s}$, 12H), 1.08 (s, 9H) ppm. ${ }^{19} \mathrm{~F}-\mathrm{NMR}\left(\mathrm{CDCl}_{3}, 376 \mathrm{MHz}\right): \delta-62.41\left(\mathrm{CF}_{3}\right),-73.72\left(\mathrm{CF}_{3} \mathrm{SO}_{3}\right)$. ${ }^{13} \mathrm{C}-\mathrm{NMR}\left(\mathrm{CDCl}_{3}, 101 \mathrm{MHz}\right): \delta 328.9,181.8,161.9$ (q, J = 49.8 Hz), 149.4, 142.1, 129.0 (qq, ${ }^{2} J_{C F}=31.0 \mathrm{~Hz},{ }^{3} J_{C B}=2.5 \mathrm{~Hz}$ ), 128.6, $126.1,124.7$ (q, ${ }^{1} J_{C F}=272.5 \mathrm{~Hz}$ ), 117.6, 51.9, 30.1, 21.1, 18.1, 17.8. Elemental analysis (\%) calcd. $\mathrm{C}_{65} \mathrm{H}_{49} \mathrm{BCl}_{2} \mathrm{~F}_{27} \mathrm{MoN}_{3} \mathrm{O}_{3} \mathrm{~S}: \mathrm{C}$ 47.52, H 3.01, N 2.56; found: C 47.39, H 3.220, N 2.78.

$\left[\mathrm{Mo}\left(\mathrm{N}-2-\mathrm{CF}_{3}-\mathrm{C}_{6} \mathrm{H}_{4}\right)\left(\mathrm{CHCMe}_{2} \mathrm{Ph}\right)(\mathrm{IMes})(\mathrm{OTf})\right]\left[\mathrm{B}\left(\mathrm{Ar}^{\mathrm{F}}\right)_{4}\right]$

(I19):

$\mathrm{Mo}\left(\mathrm{N}-2-\mathrm{CF}_{3}-\right.$ $\left.\mathrm{C}_{6} \mathrm{H}_{4}\right)\left(\mathrm{CHCMe}_{2} \mathrm{Ph}\right)(\mathrm{IMes})(\mathrm{OTf})_{2} \cdot \mathrm{CH}_{2} \mathrm{Cl}_{2}(\mathbf{I 1 2}, 287 \mathrm{mg}, 0.267 \mathrm{mmol})$ was dissolved in 7 $\mathrm{mL} \mathrm{CH} \mathrm{Cl}_{2}$ and cooled to $-35^{\circ} \mathrm{C}$. Solid $\mathrm{TIB}\left(\mathrm{ArF}^{\mathrm{F}}\right)_{4} \cdot \mathrm{CH}_{2} \mathrm{Cl}_{2}(308 \mathrm{mg}, 0.267 \mathrm{mmol})$ was added. The mixture was stirred at room temperature for $30 \mathrm{~min}$. Then, the mixture was 
cooled and filtered over celite. The filtrate was reduced to dryness leaving a yellow oil. The oily residue was dissolved in $2 \mathrm{~mL} \mathrm{CH}_{2} \mathrm{Cl}_{2}$ and filtered over celite again. The solvent was removed in vacuo affording the product as a bright yellow foam (Yield: 432 mg, 95\%). ${ }^{1} \mathrm{H}$ NMR (400 MHz, $\left.\mathrm{CDCl}_{3}\right): \delta 12.65$ (br s, 1H), 7.70 (br m, 8H), 7.51 (br s, 4H), $7.50(\mathrm{~m}, 1 \mathrm{H}), 7.46(\mathrm{~m}, 1 \mathrm{H}), 7.40(\mathrm{~m}, 1 \mathrm{H}), 7.33(\mathrm{~s}, 2 \mathrm{H}), 7.17(\mathrm{~m}, 2 \mathrm{H}), 7.11(\mathrm{~m}, 2 \mathrm{H})$, $7.05(\mathrm{~m}, 2 \mathrm{H}), 6.88\left(\mathrm{~d},{ }^{3} \mathrm{~J}_{\mathrm{HH}}=7.3 \mathrm{~Hz}, 1 \mathrm{H}\right), 6.82(\mathrm{~s}, 2 \mathrm{H}), 6.64(\mathrm{~s}, 2 \mathrm{H}), 2.15(\mathrm{~s}, 6 \mathrm{H}), 1.92$ (s, 6H), 1.91 (s, 6H), 1.52 (s, 3H), $1.42(\mathrm{~s}, 3 \mathrm{H}) .{ }^{19} \mathrm{~F} \mathrm{NMR} \mathrm{(376} \mathrm{MHz,} \mathrm{CDCl} 3$ ): $\delta-59.91$ (s, $\mathrm{CF}_{3}$-Imido), -62.40 (B(ArF) 4 ), -73.88 (OTf). ${ }^{13} \mathrm{C} \mathrm{NMR} \mathrm{(101} \mathrm{MHz,} \mathrm{CDCl}_{3}$ ): $\delta 324.3$, 180.7, $161.6\left(m, B(A r F)_{4}\right), 150.0,144.7,141.9,134.9\left(m, B(A r F)_{4}\right), 134.4,133.8,133.5$, 131.9, 131.1, 130.8, 130.6, 130.0, $129.2\left(\mathrm{~m}, \mathrm{~B}(\mathrm{ArF})_{4}\right), 129.1,127.8,126.7,126.3$, 126.1, 126.0, 123.3, 120.6, 117.6 (m, B(ArF) $\left.)_{4}\right), 58.9,31.1,29.1,21.1,17.8$ (Mes-Me), 17.7. Elemental analysis (\%) calcd. for $\mathrm{C}_{71} \mathrm{H}_{52} \mathrm{BF}_{30} \mathrm{MoN}_{3} \mathrm{O}_{3} \mathrm{~S}$ : C 50.05; H 3.08; N 2.47. Found: C 49.97; H 3.38; N 2.57.

$\left[\mathrm{Mo}\left(\mathrm{N}-{ }^{\mathrm{t}} \mathrm{Bu}\right)(5 \mathrm{Mes})\left(\mathrm{CHCMe}_{2} \mathrm{Ph}\right)(\mathrm{MeCN})_{2}(\mathrm{OTf})\right]\left[\mathrm{B}\left(\mathrm{Ar}^{\mathrm{F}}\right)_{4}\right](\mathbf{2 0})$ : A cold solution $\left(-35^{\circ} \mathrm{C}\right)$ of $\mathrm{Mo}\left(\mathrm{N}-{ }^{-} \mathrm{Bu}\right)(5 \mathrm{Mes})\left(\mathrm{CHCMe}_{2} \mathrm{Ph}\right)(\mathrm{OTf})_{2}(0.15 \mathrm{~g}, 0.17 \mathrm{mmol}, 1$ eq. $)$ in $\mathrm{CH}_{2} \mathrm{Cl}_{2}(4 \mathrm{~mL})$ was added to a cold suspension of $\mathrm{NaB}\left(\mathrm{Ar}^{\mathrm{F}}\right)_{4}(0.15 \mathrm{~g}, 0.17 \mathrm{mmol}, 1 \mathrm{eq})$ in $\mathrm{CH}_{2} \mathrm{Cl}_{2}$ $(3 \mathrm{~mL})$ and a few drops of $\mathrm{MeCN}$. The reaction was stirred for one hour at room temperature and filtered through a pad of celite. The solvent was removed in vacuo and the residue was co-evaporated with $n$-pentane to yield a yellow foam. Yield: $0.26 \mathrm{~g}$, $0.16 \mathrm{mmol}, 97 \%$. ${ }^{1} \mathrm{H}$ NMR $\left(\mathrm{CDCl}_{3}, 400 \mathrm{MHz}\right) \delta 14.34(\mathrm{~s}, 1 \mathrm{H}), 7.91-7.83(\mathrm{~m}, 8 \mathrm{H})$, $7.70(\mathrm{~s}, 4 \mathrm{H}), 7.48-7.40(\mathrm{~m}, 2 \mathrm{H}), 7.37-7.29(\mathrm{~m}, 3 \mathrm{H}), 7.15(\mathrm{~s}, 4 \mathrm{H}), 2.45(\mathrm{~s}, 6 \mathrm{H}), 2.33$ (s, 6H), $2.23(\mathrm{~s}, 6 \mathrm{H}), 1.99(\mathrm{~s}, 6 \mathrm{H}), 1.88(\mathrm{~s}, 3 \mathrm{H}), 1.37(\mathrm{~s}, 9 \mathrm{H}), 0.91(\mathrm{~s}, 3 \mathrm{H}) .{ }^{19} \mathrm{~F}$ NMR $\left(\mathrm{CDCl}_{3}, 376 \mathrm{MHz}\right) \delta-62.36,-76.99 .{ }^{13} \mathrm{C} \mathrm{NMR}\left(\mathrm{CDCl}_{3}, 101 \mathrm{MHz}\right) \delta 335.3,181.6,161.8$ $\left(q,{ }^{1} J_{B C}=49.8 \mathrm{~Hz}\right), 145.3,141.3,136.2,135.9,135.5,134.9,130.3,130.0,129.0$ (qq, $\left.{ }^{2} J_{C F}=32.4 \mathrm{~Hz},{ }^{3} J_{C B}=2.8 \mathrm{~Hz}\right), 128.6,126.7,126.3,124.7\left(q,{ }^{1} J_{C F}=272.4 \mathrm{~Hz}\right), 117.6$, 
54.8, 30.0, 29.4, 28.1, 21.0, 18.3, 18.0, 2.6.. Elemental analysis (\%) calcd. $\mathrm{C}_{72} \mathrm{H}_{63} \mathrm{BF}_{27} \mathrm{MoN}_{5} \mathrm{O}_{3} \mathrm{~S}: \mathrm{C}, 50.91 ; \mathrm{H}, 3.74 ; \mathrm{N}, 4.12$; found $\mathrm{C}, 50.81 ; \mathrm{H}, 4.038 ; \mathrm{N}, 3.76$.

\section{$\left[\mathrm{Mo}\left(\mathrm{N}-2-{ }^{\mathrm{t}} \mathrm{BuC}_{6} \mathrm{H}_{4}\right)(5 \mathrm{Mes})\left(\mathrm{CHCMe}_{2} \mathrm{Ph}\right)\left(\mathrm{OCH}\left(\mathrm{CF}_{3}\right)_{2}\right)\right]\left[\mathrm{B}\left(\mathrm{Ar}^{\mathrm{F}}\right)_{4}\right]$}

Lithiumhexafluoroisopropoxide $(0.05 \mathrm{~g}, 0.26 \mathrm{mmol}, 1.5 \mathrm{eq}$.) was added to a cold ($\left.35^{\circ} \mathrm{C}\right)$ solution of $\left[\mathrm{Mo}\left(\mathrm{N}-2{ }^{\mathrm{t}} \mathrm{BuPh}\right)(5 \mathrm{Mes})\left(\mathrm{CHCMe}_{2} \mathrm{Ph}\right)(\mathrm{OTf})\right]\left[\mathrm{B}\left(\mathrm{ArF}^{\mathrm{F}}\right)_{4}\right] \quad(\mathbf{I 1 5}, 0.30 \mathrm{~g}$, $0.18 \mathrm{mmol}, 1$ eq.) in $\mathrm{CH}_{2} \mathrm{Cl}_{2}$. After stirring the reaction mixture at room temperature for 16 hours, the suspension was filtered through a pad of celite. The product was crystallized from a mixture of $\mathrm{CH}_{2} \mathrm{Cl}_{2}$, diethyl ether and n-pentane. Yield: $0.22 \mathrm{~g}$, $0.13 \mathrm{mmol}, 73 \%$. ${ }^{1} \mathrm{H}-\mathrm{NMR}\left(\mathrm{CD}_{2} \mathrm{Cl}_{2}, 400 \mathrm{MHz}\right): \delta 12.28\left(\mathrm{~s}, 1 \mathrm{H},{ }^{1} \mathrm{~J}_{\mathrm{CH}}=120 \mathrm{~Hz}\right.$, $\mathrm{CHCMe}_{2} \mathrm{Ph}$ ), 7.73 (br s, 8H), 7.56 (s, 4H), 7.49 (s, 2H), 7.32-7.27 (m, 2H), 7.22-7.16 (m, 3H), 7.13-7.08 (m, 1H), 7.04-7.00 (m, 2H), 6.92-6.87 (m, 5H), 4.50 (hept., $1 \mathrm{H}$, $J=5,9 \mathrm{~Hz}), 2.20(\mathrm{~s}, 6 \mathrm{H}), 2.06(\mathrm{~s}, 6 \mathrm{H}), 1.98(\mathrm{~s}, 6 \mathrm{H}), 1.46(\mathrm{~s}, 3 \mathrm{H}), 1.26(\mathrm{~s}, 3 \mathrm{H}), 1.14(\mathrm{~s}$, 9H). ${ }^{19} \mathrm{~F}-\mathrm{NMR}\left(\mathrm{CD}_{2} \mathrm{Cl}_{2}, 376 \mathrm{MHz}\right): \delta-62.89\left(\mathrm{~s}, 24 \mathrm{~F}, \mathrm{CF}_{3}\right),-74.12\left(\mathrm{~m}, 3 \mathrm{~F}, \mathrm{CHCF}_{3}\right)$, $74.53\left(\mathrm{~m}, 3 \mathrm{~F}, \mathrm{CHCF}_{3}\right) .{ }^{13} \mathrm{C}-\mathrm{NMR}\left(\mathrm{CD}_{2} \mathrm{Cl}_{2}, 101 \mathrm{MHz}\right): \delta 309.2,179.6,162.4$ (q, $\left.{ }^{1} J_{B C}=49.9 \mathrm{~Hz}\right), 156.0,148.6,146.6,142.6,135.4,135.1,134.8,134.7,134.0,131.7$, 131.2, 131.1, 129.5 (qq, ${ }^{2} J_{C F}=34.9 \mathrm{~Hz},{ }^{3} J_{C B}=2.8 \mathrm{~Hz}$ ), 127.8, 127.6, 127.0, 126.1, $125.2\left(\mathrm{q},{ }^{1} \mathrm{~J}_{\mathrm{CF}}=271.8 \mathrm{~Hz}\right), 118.1,78.7\left(\mathrm{hept},{ }^{2} \mathrm{~J}_{\mathrm{CF}}=33.3 \mathrm{~Hz}\right), 58.6,36.0,32.1,30.5$, 30.3, 21.3, 18.2, 18.0. Elemental analysis (\%) calcd. $\mathrm{C}_{75} \mathrm{H}_{61} \mathrm{BF}_{30} \mathrm{MoN}_{3} \mathrm{O}_{2}: \mathrm{C} 53.08, \mathrm{H}$ 3.62, N 2.48; found: C 53.35, H 3.99, N 2.61.

Synthesis of Mo-1.0: $\mathrm{Mo}\left(\mathrm{N}-2-\mathrm{tBuC}_{6} \mathrm{H}_{4}\right)\left(\mathrm{CHCMe}_{2} \mathrm{Ph}\right)(\mathrm{OTf})_{2}$ (DME) (1000 mg, $1.3 \mathrm{mmol}$ ) was suspended in diethyl ether $(20 \mathrm{~mL})$ and cooled to $-35^{\circ} \mathrm{C}$. Lithium pyrrolide (191 mg, $2.6 \mathrm{mmol}$ ) was added and the reaction was stirred for one hour at room temperature. The solvent was removed in vacuo and the residue was extracted with $\mathrm{CH}_{2} \mathrm{Cl}_{2}$. The resulting suspension was filtered through a pad of Celite and the 
solvent was removed again. The residue was stirred with pentane until crystallization commenced. Filtration yielded Mo-1.0 as yellow crystals in $64 \%$ yield. ${ }^{1} \mathbf{H}$ NMR (400 MHz, $\left.\mathrm{CD}_{2} \mathrm{Cl}_{2}\right): \delta 13.05(\mathrm{~s}, 1 \mathrm{H})^{*}, 7.37-7.20(\mathrm{~m}, 5 \mathrm{H}), 7.17\left(\mathrm{t},{ }^{3} \mathrm{JHH}=7.7 \mathrm{~Hz}, 1 \mathrm{H}\right)$, $7.08\left(\mathrm{t},{ }^{3} \mathrm{JHH}_{\mathrm{HH}}=8.3 \mathrm{~Hz}, 1 \mathrm{H}\right), 6.96\left(\mathrm{t},{ }^{3} \mathrm{~J}_{\mathrm{HH}}=7.0 \mathrm{~Hz}, 1 \mathrm{H}\right), 6.62\left(\mathrm{~d},{ }^{3} \mathrm{~J}_{\mathrm{HH}}=7.9 \mathrm{~Hz}, 1 \mathrm{H}\right), 6.35$ (s, 4H), $6.13(\mathrm{~s}, 4 \mathrm{H}), 1.57(\mathrm{~s}, 6 \mathrm{H}), 1.23(\mathrm{~s}, 9 \mathrm{H}) .{ }^{13} \mathrm{C}$ NMR (101 MHz, $\left.\mathrm{CD}_{2} \mathrm{Cl}_{2}\right)^{*}: \delta 154.7$, $148.5,146.3,134.1,128.9,128.4,127.1,126.7,126.2,109.0,57.6,35.9,31.0,30.8$. Elemental analysis (\%) calcd. for $\mathrm{C}_{28} \mathrm{H}_{33} \mathrm{MoN}_{3}$ : C 66.26, $\mathrm{H}$ 6.55, N 8.28; found: $\mathrm{C} 65.85$, $\mathrm{H} 6.545, \mathrm{~N}$ 8.16. *Determination of syn- or anti-configuration was not possible due to the broad signals. ${ }^{* *}$ The alkylidene carbon signal was not visible although $100 \mathrm{mg}$ of catalyst were used for ${ }^{13} \mathrm{C}$ NMR spectroscopy since all signals were very broad, most probably due to fast exchange of the coordination modes of the pyrrolide ligand.

Synthesis of Mo-3.0: $\mathrm{Mo}\left(\mathrm{N}-2,6-{ }^{-} \mathrm{Pr}_{2} \mathrm{C}_{6} \mathrm{H}_{3}\right)\left(\mathrm{CHCMe}_{2} \mathrm{Ph}\right)(\mathrm{OTf})_{2}$ (DME) $(1110 \mathrm{mg}$, $1.4 \mathrm{mmol})$ was suspended in diethylether $(25 \mathrm{~mL})$ and cooled to $-35^{\circ} \mathrm{C}$. Lithium pyrrolide (205 mg, $2.8 \mathrm{mmol}$ ) was added and the reaction was stirred for two hours at room temperature. The solvent was removed in vacuo and the residue was extracted with toluene $(30 \mathrm{~mL})$. The resulting suspension was filtered through a pad of Celite and the solvent was removed again. The residue was stirred with pentane $(20 \mathrm{~mL})$ at room temperature until crystallization commenced. Filtration yielded Mo-3.0 as yellow crystals in $81 \%$ yield. $\left.{ }^{1} \mathrm{H} \mathrm{NMR} \mathrm{(400} \mathrm{MHz,} \mathrm{CDCl}_{3}\right): \delta 13.12(\mathrm{~s}, 1 \mathrm{H}), 7.37-7.27(\mathrm{~m}, 4 \mathrm{H})$, $7.27-7.20(\mathrm{~m}, 1 \mathrm{H}), 7.10(\mathrm{dd}, J=8.4,7.0 \mathrm{~Hz}, 1 \mathrm{H}), 6.99(\mathrm{~d}, J=7.3 \mathrm{~Hz}, 2 \mathrm{H}), 6.23(\mathrm{~s}$, 4H), $6.10(\mathrm{~s}, 4 \mathrm{H}), 3.12(\mathrm{~s}, 2 \mathrm{H}), 1.49(\mathrm{~s}, 6 \mathrm{H}), 0.93(\mathrm{~d}, J=6.8 \mathrm{~Hz}, 12 \mathrm{H}) .{ }^{13} \mathrm{C}$ NMR (101 MHz, $\left.\mathrm{CDCl}_{3}\right): \delta 304.4,151.8,149.3,147.9,132.7,128.5,128.1,126.4,126.4$, 123.3, 108.0, 57.5, 30.5, 27.7, 24.3. Elemental analysis (\%) calcd. for $\mathrm{C}_{30} \mathrm{H}_{37} \mathrm{MoN}_{3}$ : C 67.28, H 6.96, N 7.85; found: C 67.60, H 7.293, N 7.55. 
Synthesis of Mo-1.1: Mo-1.0 (467.2 mg, $0.9 \mathrm{mmol})$ was dissolved in diethyl ether and cooled to $-35^{\circ} \mathrm{C}$. A solution of 1,3-diisopropylimidazol-2-ylidene (140 mg, $0.9 \mathrm{mmol}$ ) in diethyl ether at $-35^{\circ} \mathrm{C}$ was added to the solution of Mo-1.0. After 30 minutes a yellow precipitate formed. After two hours the solid was filtered off and recrystallized from a mixture of $\mathrm{CH}_{2} \mathrm{Cl}_{2}$, diethyl ether and pentane. Mo-1.1 was isolated in the form of yellow crystals in 93\% yield. Mo-1.1 can also be used as received from the reaction mixture without recrystallization. ${ }^{1} \mathrm{H}$ NMR $\left(\mathbf{4 0 0} \mathbf{M H z}, \mathrm{CDCl}_{3}\right): \delta 13.87(\mathrm{~s}$, $\left.1 \mathrm{H},{ }^{1} \mathrm{~J}_{\mathrm{CH}}=123.7 \mathrm{~Hz}, \mathrm{syn}\right), 7.40(\mathrm{br} \mathrm{s}, 2 \mathrm{H}), 7.24(\mathrm{~s}, 1 \mathrm{H}), 7.12-7.05(\mathrm{~m}, 5 \mathrm{H}), 6.96$ (br s, $2 \mathrm{H}), 6.87\left(\mathrm{t},{ }^{3} \mathrm{~J}_{\mathrm{HH}}=7.2 \mathrm{~Hz}, 1 \mathrm{H}\right), 6.79\left(\mathrm{t},{ }^{3} \mathrm{~J}_{\mathrm{HH}}=7.5 \mathrm{~Hz}, 1 \mathrm{H}\right), 6.52-6.50(\mathrm{~m}, 3 \mathrm{H}), 6.41(\mathrm{~s}$, 2H), 6.29 (br s, 2H), 4.40-4.34 (m, 2H), $2.04(\mathrm{~s}, 3 \mathrm{H}), 1.62(\mathrm{~s}, 3 \mathrm{H}), 1.52(\mathrm{~s}, 9 \mathrm{H}), 0.89$ (d, $\left.{ }^{3} \mathrm{HHH}_{\mathrm{HH}}=6.7 \mathrm{~Hz}, 6 \mathrm{H}\right), 0.67\left(\mathrm{~d},{ }^{3} \mathrm{JHH}_{\mathrm{HH}}=6.6 \mathrm{~Hz}, 6 \mathrm{H}\right) .{ }^{13} \mathrm{C} \mathrm{NMR}\left(101 \mathrm{MHz}, \mathrm{CDCl}_{3}\right): \delta 299.72$, $185.9,153.5,147.7,145.8,131.0,131.0,128.7,126.5,126.2,125.8,118.1,107.1$, $107.2,56.3,53.9,35.2,32.9,30.4,29.5,23.1,23.0$.

Synthesis of Mo-1.2: Mo-1.0 (195 mg, $0.4 \mathrm{mmol}$ ) was dissolved in diethyl ether and a solution of 1,3,4-triphenyl-1,2,4-triazol-5-ylidene $(174.7 \mathrm{mg}, 0.4 \mathrm{mmol})$ in diethyl ether was added at $-35^{\circ} \mathrm{C}$. The solution was stirred for four hours and reduced until a saturated solution was reached. Then, the solution was layered with pentane and crystallized at $-35^{\circ} \mathrm{C}$ to give Mo-1.2 in $62 \%$ yield. Mo-1.2 co-crystallizes with one molecule of diethyl ether. For elemental analysis crystallized Mo-1.2 $\times \mathrm{Et}_{2} \mathrm{O}$ was dissolved in dichloromethane and the solution was evaporated to dryness to remove diethyl ether. ${ }^{1} \mathrm{H}$ NMR $\left(\mathbf{4 0 0} \mathbf{~ M H z}, \mathbf{C D C l}_{3}\right): \delta 13.87(\mathrm{br} \mathrm{s}, 0.5 \mathrm{H})^{*}, 13.41$ (br s, 0.5H), 7.80 (br s, 1H), 7.44-7.41 (m, 1H), 7.34-7.27 (m, 6H), 7.24-7.12 (m, 7H), 7.07-6.99 (m, 6H), 6.54-6.26 (br s, 5H), 6.18-6.14 (m, 3H), 6.05-5.97 (m, 3H), 1.59 (s, 3H), 0.93-0.77 (br s, 12H). ${ }^{13} \mathrm{C}$ NMR (101 MHz, $\left.\mathrm{CDCl}_{3}\right): \delta 310.12,309.15,192.8,191.5,155.9,153.8$, 148.3, 146.5, 140.6, 140.0, 136.6, 135.9, 132.0 (br s), 131.8 (br s), 131.6 (br s), 131.4 
(br s), 130.6 (br s), 130.2 (br s), 130.0 (br s), 129.7, 129.3, 128.7, 126.7 (br s), 126.4, 126.0 , 125.0 (br s), 122.9, 109.2, 108.4, 107.0, 66.2 (Et $2 \mathrm{O}), 56.6$ (br s), 35.2, 32.1, 31.9, 30.9, $15.7\left(\mathrm{Et}_{2} \mathrm{O}\right)$. Elemental analysis (\%) calcd. for $\mathrm{C}_{49} \mathrm{H}_{51} \mathrm{MoN}_{6}$ : C 71.78, H 6.27, N 10.25; found: C 71.52, H 6.276, N 9.93. * Mo-1.2 was isolated as mixture of two isomers (1/1), however, determination of syn- or anti-configuration was impossible due to the broad resonances. The sum of the integrals of both isomers was set to one in the ${ }^{1} \mathrm{H}$ NMR spectrum. Most probably the isomers differ in the coordination mode of the pyrrolide ligands and constantly interchange, thereby explaining the broad signals in both the ${ }^{1} \mathrm{H}$ and ${ }^{13} \mathrm{C}$ NMR spectrum.

Synthesis of Mo-1.3: Mo-1.0 (400 mg, $0.8 \mathrm{mmol}$ ) was dissolved in $\mathrm{CH}_{2} \mathrm{Cl}_{2}$ and 4,5$\mathrm{Cl}_{2}$-1,3-Me - -imidazol-2-ylidene $\mathrm{Agl}$ (315 $\mathrm{mg}, 0.8 \mathrm{mmol}$ ) was added as a solid under exclusion of light. The resulting suspension was stirred for six hours and then filtered over Celite ${ }^{\circledR}$ to remove Agl. All volatiles were removed, and the resulting brownish residue was treated with pentane and diethyl ether until a yellow solid was obtained. This solid was recrystallized from a mixture of $\mathrm{CH}_{2} \mathrm{Cl}_{2}$, diethyl ether and pentane to yield Mo-1.3 in 57\% yield as yellow crystals. ${ }^{1} \mathbf{H}$ NMR $\left(400 \mathbf{M H z}, \mathrm{CD}_{2} \mathrm{Cl}_{2}\right): \delta 13.62(\mathrm{~s}$, $1 \mathrm{H},{ }^{1} \mathrm{~J}_{\mathrm{CH}}=120.7 \mathrm{~Hz}$, syn), 7.44- 7.41 (m, 2H), 7.37-7.35 (m, 1H), 7.31-7.27 (m, 2H), 7.23-7.21 (m, 1H), 7.16-7.07 (m, 3H), 6.79-6.76 (m, 1H), 6.59 (br s, 2H), 6.05 (br s, 2H), 5.99 (br s, 2H), 5,90 (br s, 2H), $3.10(\mathrm{~s}, 6 \mathrm{H}), 1.95$ (s, 3H), $1.78(\mathrm{~s}, 3 \mathrm{H}), 1.24(\mathrm{~s}$, 9H). ${ }^{13} \mathrm{C}$ NMR (101 MHz, $\left.\mathrm{CD}_{2} \mathrm{Cl}_{2}\right): \delta 306.1,306.0,189.9,154.6,147.6,146.0,131.9$, $131.5,131.2,129.5,129.3,129.2,127.2,127.2,127.0,126.8,126.7,126.6,119.0$, $108.3,107.6,57.03,36.8,35.6,31.1,30.8,30.5,30.4$.

Synthesis of Mo-2.1: $\mathrm{Mo}\left(\mathrm{N}-2,6-\mathrm{Me}_{2} \mathrm{C}_{6} \mathrm{H}_{3}\right)\left(\mathrm{CHCMe}_{2} \mathrm{Ph}\right)(\mathrm{OTf})_{2}$ (DME) (497 mg, $0.68 \mathrm{mmol}$ ) was suspended in diethyl ether $(10 \mathrm{~mL})$ and lithium pyrrolide $(99 \mathrm{mg}$, $1.36 \mathrm{mmol}$ ) was added. The mixture was stirred for one hour at room temperature. 
Then, a solution of 1,3-diisopropylimidazol-2-ylidene $(103 \mathrm{mg}, 0.68 \mathrm{mmol})$ in diethyl ether $(5 \mathrm{~mL})$ was added. The reaction mixture was stirred for three hours at room temperature and the solvent was removed in vacuo. The residue was extracted with toluene $(20 \mathrm{~mL})$. The suspension was filtered through Celite and the filtrate was concentrated to dryness. The residue was treated with diethyl ether, resulting in a yellow precipitate. The precipitate was filtered off and crystallized from a mixture of dichloromethane, diethyl ether and pentane to afford Mo-2.1 in $75 \%$ yield. ${ }^{1} \mathbf{H}$ NMR (400 MHz, $\left.\mathrm{CD}_{2} \mathrm{Cl}_{2}\right): \delta 13.59(\mathrm{~s}, 1 \mathrm{H}), 7.50-7.45(\mathrm{~m}, 2 \mathrm{H}), 7.35-7.29(\mathrm{~m}, 2 \mathrm{H}), 7.24-$ $7.18(\mathrm{~m}, 1 \mathrm{H}), 7.11(\mathrm{~s}, 2 \mathrm{H}), 6.93(\mathrm{~s}, 3 \mathrm{H}), 6.71(\mathrm{t}, J=1.8 \mathrm{~Hz}, 2 \mathrm{H}), 6.16(\mathrm{t}, J=1.8 \mathrm{~Hz}$, 2H), $5.83-5.78(\mathrm{~m}, 4 \mathrm{H}), 4.22\left(\right.$ hept, $\left.{ }^{3} \mathrm{~J}_{\mathrm{HH}}=6.7 \mathrm{~Hz}, 2 \mathrm{H}\right), 1.93(\mathrm{~s}, 3 \mathrm{H}), 1.89(\mathrm{~s}, 6 \mathrm{H}), 1.62$ (s, 3H), $0.99\left(\mathrm{~d},{ }^{3} \mathrm{H}_{\mathrm{HH}}=6.7 \mathrm{~Hz}, 6 \mathrm{H}\right), 0.91\left(\mathrm{~d},{ }^{3} \mathrm{JHH}_{\mathrm{HH}}=6.7 \mathrm{~Hz}, 6 \mathrm{H}\right) \cdot{ }^{13} \mathrm{C} \mathbf{~ N M R}(101 \mathrm{MHz}$, $\left.\mathrm{CD}_{2} \mathrm{Cl}_{2}\right): \delta 299.1,299.0,185.4,153.5,148.3,136.2,131.0,130.9,129.1,128.7,126.9$, 126.4, 126.3, 118.6, 107.7, 107.3, 55.1, 32.4, 29.2, 23.3, 22.8, 18.4. Elemental analysis (\%) calcd. for $\mathrm{C}_{35} \mathrm{H}_{45} \mathrm{MoN}_{5}$ : C 66.54, H 7.18, N 11.09; found: C 66.49, H 7.148, N 11.05 .

Synthesis of Mo-3.1: Mo-3.0 (400 mg, $0.75 \mathrm{mmol}$ ) was dissolved in diethyl ether and cooled to $-35^{\circ} \mathrm{C}$. A cold $\left(-35^{\circ} \mathrm{C}\right)$ solution of 1,3-diisopropylimidazol-2-ylidene (114 $\mathrm{mg}, 0.755 \mathrm{mmol})$ in diethyl ether $(4 \mathrm{~mL})$ was added, resulting in the formation of a yellow precipitate. The suspension was stirred at room temperature for one hour and filtered. The solid was washed with diethyl ether to afford Mo-3.1 in $80 \%$ yield. ${ }^{1} \mathrm{H}$ NMR (400 MHz, $\left.\mathrm{CDCl}_{3}\right): \delta 13.55(\mathrm{~s}, 1 \mathrm{H}), 7.49-7.42(\mathrm{~m}, 2 \mathrm{H}), 7.32\left(\mathrm{t},{ }^{3} \mathrm{~J}_{\mathrm{HH}}=7.7 \mathrm{~Hz}, 2 \mathrm{H}\right)$, $7.26-7.18(\mathrm{~m}, 1 \mathrm{H}), 7.11-7.01(\mathrm{~m}, 5 \mathrm{H}), 6.68(\mathrm{t}, J=1.8 \mathrm{~Hz}, 2 \mathrm{H}), 6.23(\mathrm{t}, J=1.8 \mathrm{~Hz}$, 2H), $5.95(\mathrm{~s}, 4 \mathrm{H}), 4.29$ (hept, ${ }^{3} \mathrm{~J}_{\mathrm{HH}}=6.7 \mathrm{~Hz}, 2 \mathrm{H}$ ), 3.30 (hept, ${ }^{3} \mathrm{JHH}_{\mathrm{HH}}=6.8 \mathrm{~Hz}, 2 \mathrm{H}$ ), 2.07 $(\mathrm{s}, 3 \mathrm{H}), 1.67(\mathrm{~s}, 3 \mathrm{H}), 1.15\left(\mathrm{~d},{ }^{3} \mathrm{~J}_{\mathrm{HH}}=6.8 \mathrm{~Hz}, 6 \mathrm{H}\right), 1.07\left(\mathrm{~d},{ }^{3} \mathrm{~J}_{\mathrm{HH}}=6.7 \mathrm{~Hz}, 6 \mathrm{H}\right), 0.78(\mathrm{~d}$, $\left.{ }^{3} J_{\mathrm{HH}}=6.6 \mathrm{~Hz}, 6 \mathrm{H}\right), 0.62\left(\mathrm{~d},{ }^{3} \mathrm{H}_{\mathrm{HH}}=6.7 \mathrm{~Hz}, 6 \mathrm{H}\right) .{ }^{13} \mathrm{C} \mathrm{NMR}\left(101 \mathrm{MHz}, \mathrm{CDCl}_{3}\right): \delta 298.5$, 
$185.8,149.9,148.3,147.1,131.1,130.8,128.7,127.0,126.4,125.8,123.8,118.3$, $107.5,106.8,54.0,54.0,32.6,28.8,27.7,24.8,24.7,23.2,22.9$. Elemental analysis (\%) calcd. for $\mathrm{C}_{39} \mathrm{H}_{53} \mathrm{MoN}_{5}$ : C 68.10, H 7.77, N 10.18; found: C 67.93, H 7.738, N 10.10.

Synthesis of Mo-4.1: $\mathrm{Mo}(\mathrm{N}-\mathrm{tBu})\left(\mathrm{CHCMe}_{2} \mathrm{Ph}\right)(\mathrm{OTf})_{2}(\mathrm{DME})(500 \mathrm{mg}, 0.73 \mathrm{mmol})$ was dissolved in diethyl ether $(15 \mathrm{~mL})$ and lithium pyrrolide $(106 \mathrm{mg}, 1.45 \mathrm{mmol})$ was added. The resulting suspension was stirred at room temperature for one hour. A solution of 1,3-diisopropylimidazol-2-ylidene $(111 \mathrm{mg}, 0.73 \mathrm{mmol})$ in diethyl ether $(5 \mathrm{~mL})$ was added and the reaction mixture was stirred for two more hours. The solvent was removed in vacuo, the resulting residue was extracted with toluene $(2 \times 15 \mathrm{~mL})$ and filtered over Celite to remove lithium pyrrolide. The filtrate was concentrated to dryness and the residue was treated with diethyl ether to afford a light yellow solid. [Mo-4.1] was isolated in $54 \%$ yield. ${ }^{1} \mathrm{H}$ NMR (400 MHz, $\left.\mathbf{C D C l}_{3}\right): \delta 13.14(\mathrm{~s}, 1 \mathrm{H}), 7.36-7.30(\mathrm{~m}$, 2H), $7.26-7.21(\mathrm{~m}, 2 \mathrm{H}), 7.18-7.13(\mathrm{~m}, 1 \mathrm{H}), 7.00(\mathrm{~s}, 2 \mathrm{H}), 6.74(\mathrm{t}, J=1.8 \mathrm{~Hz}, 2 \mathrm{H})$, $6.22(\mathrm{t}, J=1.8 \mathrm{~Hz}, 2 \mathrm{H}), 5.91(\mathrm{t}, J=1.8 \mathrm{~Hz}, 2 \mathrm{H}), 5.82(\mathrm{t}, J=1.8 \mathrm{~Hz}, 2 \mathrm{H}), 4.31$ (brs, 2H), $2.12(\mathrm{~s}, 3 \mathrm{H}), 1.57(\mathrm{~s}, 3 \mathrm{H}), 1.50(\mathrm{~s}, 3 \mathrm{H}), 1.38(\mathrm{~s}, 9 \mathrm{H}), 1.09-0.31(\mathrm{~m}, 9 \mathrm{H}) .{ }^{13} \mathrm{C}$ NMR (101 MHz, $\left.\mathrm{CDCl}_{3}\right): \delta 298.3,184.9,147.9,132.7,129.2,128.5,126.3,125.8,117.8$, $106.9,106.8,71.3,52.0,31.7,31.2,30.7,22.7$. Elemental analysis (\%) calcd. for $\mathrm{C}_{31} \mathrm{H}_{45} \mathrm{MoN}_{5}$ : C 63.79, H 7.77, N 12.00; found: C 63.78, H 7.762, N 12.01.

Synthesis of I24: Mo-1.1 (20 mg, $0.03 \mathrm{mmol}$ ) was dissolved in $\mathrm{CH}_{2} \mathrm{Cl}_{2}$ and cooled to $-35^{\circ} \mathrm{C}$. A solution of $\mathrm{N}, \mathrm{N}$-dimethyl anilinium $\mathrm{B}\left(\mathrm{Ar}^{\mathrm{F}}\right)_{4}(31 \mathrm{mg}, 0.03 \mathrm{mmol})$ in diethyl ether at $-35^{\circ} \mathrm{C}$ was added dropwise. After three hours the solvent was removed and the resulting residue was washed with pentane to remove the aniline and the pyrrole side products. $\mathbf{1 2 4}$ was isolated as yellow solid foam in quantitative yield. $\mathbf{2 4}$ can also be crystallized from a mixture of $\mathrm{CH}_{2} \mathrm{Cl}_{2}$, diethyl ether and pentane to yield light yellow crystals. ${ }^{1} \mathrm{H}$ NMR $\left(400 \mathrm{MHz}, \mathrm{CD}_{2} \mathrm{Cl}_{2}\right): \delta 14.05\left(\mathrm{~s}, 1 \mathrm{H},{ }^{1} \mathrm{~J}_{\mathrm{CH}}=127.3 \mathrm{~Hz}\right.$, syn), $7.74(\mathrm{br} \mathrm{s}$, 
8H), 7.58 (br s, 4H), 7.41- 7.31 (m, 9H), 7.26- 7.22 (m, 2H), 7.11- $7.07(\mathrm{~m}, 1 \mathrm{H}), 6.95-$ $6.93(\mathrm{~m}, 1 \mathrm{H}), 6.59(\mathrm{~s}, 2 \mathrm{H}), 4.18(\mathrm{~s}, 4 \mathrm{H}), 1.72(\mathrm{~s}, 3 \mathrm{H}), 1.70(\mathrm{~s}, 3 \mathrm{H}), 1.25\left(\mathrm{~d},{ }^{3} \mathrm{~J}_{\mathrm{HH}}=6.4 \mathrm{~Hz}\right.$, $6 \mathrm{H}), 1.1\left(\mathrm{~d},{ }^{3} \mathrm{~J}_{\mathrm{HH}}=6.4 \mathrm{~Hz}, 6 \mathrm{H}\right) .{ }^{13} \mathrm{C}$ NMR $\left(101 \mathrm{MHz}, \mathbf{C}_{6} \mathrm{D}_{6}\right): \delta 328.8,328.56,169.2$, $162.3\left(\mathrm{q},{ }^{1} \mathrm{~J}_{\mathrm{CB}}=49.8 \mathrm{~Hz}, \mathrm{C}_{\text {ipso }}, \mathrm{B}\left(\mathrm{Ar}^{\mathrm{F}}\right)_{4}\right), 153.7,147.3,145.5,135.4\left(\mathrm{~B}\left(\mathrm{ArF}^{\mathrm{F}}\right)_{4}\right), 129.8$, $129.5\left(m^{*}, \mathrm{~B}\left(\mathrm{Ar}^{\mathrm{F}}\right)_{4}\right), 129.5,128.9,127.6,127.4,127.3,126.5,126.3,123.8,122.0$, 121.1, $118.1\left(\mathrm{~m}, \mathrm{~B}\left(\mathrm{Ar}^{\mathrm{F}}\right)_{4}\right), 116.9,113.1,61.8,40.9,36.4,32.6,30.3,30.2,23.9$. * Expected: qq, not resolved. Elemental analysis (\%) calcd. for $\mathrm{C}_{65} \mathrm{H}_{57} \mathrm{BF}_{24} \mathrm{MoN}_{4}$ : C 53.59, H 3.94, N 3.85; found: C 53.59, H 4.235, N 3.83.

Synthesis of I26: Mo-1.2 (135.2 mg, $0.2 \mathrm{mmol}$ ) was dissolved in $\mathrm{CH}_{2} \mathrm{Cl}_{2}$ and cooled to $-35^{\circ} \mathrm{C} . \mathrm{N}, \mathrm{N}$-Dimethyl anilinium $\mathrm{B}\left(\mathrm{Ar}^{\mathrm{F}}\right)_{4}(174.7 \mathrm{mg}, 0.2 \mathrm{mmol})$ was dissolved in diethyl ether and cooled to $-35^{\circ} \mathrm{C}$. The $\mathrm{N}, \mathrm{N}$-dimethyl anilinium $\mathrm{B}\left(\mathrm{Ar} \mathrm{F}_{4}\right)_{4}$ solution was slowly dropped to the solution of the precursor complex and the resulting mixture was stirred at room temperature for three hours. The solvent was removed, the resulting residue was washed with pentane to remove $\mathrm{N}, \mathrm{N}$-dimethyl aniline and pyrrole, again dried and then crystallized from a mixture of $\mathrm{CH}_{2} \mathrm{Cl}_{2}$, diethyl ether and pentane to yield light yellow crystals of $\mathbf{I 2 6}$ in $87 \%$ yield. ${ }^{1} \mathrm{H}$ NMR $\left(\mathbf{4 0 0} \mathbf{~ M H z}, \mathbf{C D C l}_{3}\right): \delta 13.67(\mathrm{br} \mathrm{s}, 1 \mathrm{H}$, $\mathrm{Mo}=\mathrm{CH})^{\star}$, 7.71-7.67 (m, 12H), 7.52-7.51 (m, 5H), 7.46-7.40 (m, 7H), 7.31-7.27 (m, 2H), 7.23-7.17 (m, 5H), 7.11-7.08 (m, 2H), 7.02-7.00 (m, 3H), 6.96-6.94 (m, 2H), 5.79 (br s, 2H), 1.51 (s, 3H), $1.11(\mathrm{~s}, 9 \mathrm{H}), 0.82(\mathrm{~s}, 3 \mathrm{H}) .{ }^{13} \mathrm{C}$ NMR (101 MHz, $\left.\mathrm{C}_{6} \mathrm{D}_{6}\right): \delta 338.1,180.3$, $162.3\left(q,{ }^{1} J_{C B}=49.8 \mathrm{~Hz}, C_{\text {ipso }} B\left(\operatorname{Ar}^{F}\right)_{4}\right), 157.4,153.9,147.9,145.8,139.3,135.6,135.4$, 132.6, 130.8, 130.0, 129.6, 129.5, 129.2, 129.0, 128.4, 127.6, 127.4, 127.1, 126.2, $125.2\left(\mathrm{q},{ }^{1} \mathrm{~J}_{\mathrm{CF}}=272.4 \mathrm{~Hz}, \mathrm{CF}_{3} \mathrm{~B}\left(\mathrm{Ar}^{\mathrm{F}}\right)_{4}\right), 123.6,118.1\left(\mathrm{~B}\left(\mathrm{ArF}^{\mathrm{F}}\right)_{4}\right), 112.0,61.7,36.1,32.1$, 30.2, 29.1. Elemental analysis (\%) calcd. for $\mathrm{C}_{76} \mathrm{H}_{56} \mathrm{BF}_{24} \mathrm{MoN}_{5}$ : C 56.98, H 3.52, N 4.37; found: C 56.90, H 3.831, N 4.18. * Determination of syn- or anti-configuration was impossible due to the broad resonance. 
Synthesis of I27: Mo-1.3 (111.4 mg, $0.2 \mathrm{mmol})$ was dissolved in $\mathrm{CH}_{2} \mathrm{Cl}_{2}(5 \mathrm{~mL})$, cooled to $-35^{\circ} \mathrm{C}$ and a chilled $\left(35^{\circ} \mathrm{C}\right)$ solution of $\mathrm{N}, \mathrm{N}$-dimethylanilinium $\mathrm{B}\left(\mathrm{Ar}^{\mathrm{F}}\right)_{4}$ etherate (175.5 mg, $0.2 \mathrm{mmol}$ ) in a mixture of $\mathrm{CH}_{2} \mathrm{Cl}_{2}$ and diethyl ether was added dropwise. The mixture was stirred for three hours at room temperature. The volatiles were removed in vacuo and the resulting residue was washed with pen-tane $(3 \times 5 \mathrm{~mL})$ to afford a dark yellow solid. This solid was recrystallized from a mixture of $\mathrm{CH}_{2} \mathrm{Cl}_{2}$, diethyl ether and pentane to afford [Mo 1.3][B(ArF)4] in $61 \%$ yield. ${ }^{1} \mathbf{H}$ NMR (400 MHz, $\left.\mathrm{CDCl}_{3}\right): \delta 14.04(\mathrm{~s}, 1 \mathrm{H}), 7.76(\mathrm{br} \mathrm{s}, 1 \mathrm{H}), 7.70(\mathrm{~s}, 8 \mathrm{H}), 7.52$ (s, 4H), 7.39 (d, $\left.{ }^{3} J_{\mathrm{HH}}=8.0 \mathrm{~Hz}, 1 \mathrm{H}\right), 7.25\left(\mathrm{~d},{ }^{3} \mathrm{~J}_{\mathrm{HH}}=10.0 \mathrm{~Hz}, 6 \mathrm{H}\right), 7.14\left(\mathrm{t},{ }^{3} \mathrm{~J}_{\mathrm{HH}}=7.6 \mathrm{~Hz}, 1 \mathrm{H}\right), 7.08-6.88$ (m, 2H), 6.56 (br s, 1H), 6.45 (br s, 1H), $3.22(\mathrm{~s}, 6 \mathrm{H}), 1.70(\mathrm{~s}, 3 \mathrm{H}), 1.62(\mathrm{~s}, 3 \mathrm{H}), 1.45$ (s, 9H). ${ }^{19} \mathrm{~F}$ NMR (376 $\left.\mathrm{MHz}, \mathrm{CDCl}_{3}\right) \delta-62.33 .{ }^{13} \mathrm{C}$ NMR (101 $\left.\mathbf{M H z}, \mathrm{CDCl}_{3}\right): \delta 333.3$, 173.0, $161.8\left(\mathrm{q},{ }^{1} \mathrm{~J}_{\mathrm{CB}}=49.8 \mathrm{~Hz}, \mathrm{C}_{\text {ipso }}, \mathrm{B}\left(\mathrm{Ar}^{\mathrm{F}}\right)_{4}\right), 153.4,145.3,145.1,135.0\left(\mathrm{~B}\left(\mathrm{Ar}^{\mathrm{F}}\right)_{4}\right)_{\text {, }}$ 133.2, 129.8, 129.2, $129.0\left(q q,{ }^{2} J_{C F}=31.3 \mathrm{~Hz},{ }^{3} J_{\mathrm{CB}}=3.1 \mathrm{~Hz}, \mathrm{~B}\left(\mathrm{Ar}^{\mathrm{F}}\right)_{4}\right), 127.6,127.4$, 127.3, 124.7 $\left(\mathrm{q},{ }^{2} \mathrm{~J}_{C F}=272.8 \mathrm{~Hz}, \mathrm{CF}_{3} \mathrm{~B}\left(\mathrm{Ar}^{\mathrm{F}}\right)_{4}\right), 121.8,117.6\left(\mathrm{~B}\left(\mathrm{Ar}^{\mathrm{F}}\right)_{4}\right), 62.5,37.4,36.1$, 30.3, 30.0, 29.9. Elemental analysis (\%) calcd. for $\mathrm{C}_{61} \mathrm{H}_{47} \mathrm{BCl}_{2} \mathrm{~F}_{24} \mathrm{MoN}_{4}: \mathrm{C} 49.85, \mathrm{H}$ 3.22, N 3.81; found: C 49.84, H 3.541, N 3.70.

Synthesis of I22: Mo-2.1 (300 mg, $0.48 \mathrm{mmol}$ ) was dissolved in $\mathrm{CH}_{2} \mathrm{Cl}_{2}$ and cooled to $-35^{\circ} \mathrm{C}$. A cold $\left(-35^{\circ} \mathrm{C}\right)$ solution of $\mathrm{N}, \mathrm{N}$-dimethylanilinium $\mathrm{B}\left(\mathrm{Ar}^{\mathrm{F}}\right)_{4}(468 \mathrm{mg}, 0.48 \mathrm{mmol})$ in diethyl ether $(5 \mathrm{~mL})$ was added. The solution was stirred at room temperature for two hours and the solvent was removed in vacuo. The residue was treated with npentane. The resulting precipitate was filtered off and crystallized from a mixture of dichloromethane, diethyl ether and pentane to afford $\mathbf{I 2 2}$ in $72 \%$ yield. ${ }^{1} \mathbf{H}$ NMR (400 MHz, $\left.\mathrm{CD}_{2} \mathrm{Cl}_{2}\right): \delta 13.84(\mathrm{~s}, 1 \mathrm{H}), 7.75(\mathrm{~s}, 8 \mathrm{H}), 7.58(\mathrm{~s}, 4 \mathrm{H}), 7.42-7.26(\mathrm{~m}, 8 \mathrm{H})$, $7.19-7.13(\mathrm{~m}, 1 \mathrm{H}), 7.09(\mathrm{dd}, J=8.6,6.4 \mathrm{~Hz}, 1 \mathrm{H}), 7.05-7.00(\mathrm{~m}, 2 \mathrm{H}), 6.57(\mathrm{~s}, 2 \mathrm{H})$, 4.12 (br s, 2H), 2.10 (s, 6H), 1.68 (s, 3H), 1.63 (s, 3H), 1.28 (br s, 6H), 1.15 (d, J = 6.6 
$\mathrm{Hz}, 6 \mathrm{H}) .{ }^{19} \mathrm{~F}$ NMR (376 MHz, $\left.\mathrm{CD}_{2} \mathrm{Cl}_{2}\right) \delta-62.76 .{ }^{13} \mathrm{C}$ NMR (101 MHz, $\mathrm{CD}_{2} \mathrm{Cl}_{2}$ ): $\delta 327.0$, 326.8, 169.8, $162.3\left(\mathrm{q},{ }^{1} J_{C B}=49.8 \mathrm{~Hz}, \mathrm{C}_{\text {ipso }} \mathrm{B}\left(\mathrm{Ar}^{\mathrm{F}}\right)_{4}\right), 153.2,147.4,135.7,135.4$ $\left(\mathrm{B}\left(\mathrm{Ar}^{\mathrm{F}}\right)_{4}\right), 129.5\left(\mathrm{qq},{ }^{2} J_{C F}=34.3 \mathrm{~Hz},{ }^{3} J_{\mathrm{CB}}=2.8 \mathrm{~Hz}, \mathrm{~B}\left(\mathrm{Ar}^{\mathrm{F}}\right)_{4}\right), 129.4,129.3,128.8,128.2$, 127.4, 126.4, $125.2\left(\mathrm{q},{ }^{1} J_{C F}=272.6 \mathrm{~Hz}, \mathrm{CF}_{3} \mathrm{~B}\left(\mathrm{Ar}^{\mathrm{F}}\right)_{4}\right), 121.8,118.3-117.9\left(\mathrm{~B}\left(\mathrm{Ar}^{\mathrm{F}}\right)_{4}\right)$, $110.0,59.8,55.0,31.0,29.7,23.6$, 19.8. Elemental analysis (\%) calcd. for $\mathrm{C}_{63} \mathrm{H}_{53} \mathrm{BF}_{24} \mathrm{MoN}_{4}$ : C 52.96, H 3.74, N 3.92; found: C 52.95, H 3.797, N 3.94.

Synthesis of I25: Mo-3.1 (250 mg, $0.36 \mathrm{mmol}$ ) was dissolved in $\mathrm{CH}_{2} \mathrm{Cl}_{2}$ and cooled to $-35^{\circ} \mathrm{C}$. Then, $0.2 \mathrm{~mL}$ of acetonitrile and a cold $\left(-35^{\circ} \mathrm{C}\right)$ solution of $\mathrm{N}, \mathrm{N}$ dimethylanilinium $\mathrm{B}\left(\mathrm{Ar}^{\mathrm{F}}\right)_{4}(385 \mathrm{mg}, 0.36 \mathrm{mmol})$ in diethyl ether $(5 \mathrm{~mL})$ was added. The solution was stirred for one hour at room temperature. Then, the solvent was removed in vacuo and the residue was triturated twice with pentane. The resulting yellow solid was dried and crystallized from a mixture of dichloromethane, diethyl ether and npentane to provide $\mathbf{I 2 5}$ in $83 \%$ yield. The compound shows broad resonances in the ${ }^{1} \mathrm{H}$ NMR spectrum, most probably due to an equilibrium between bound and dissociated acetonitrile. Therefore, one equivalent of tris(pentafluorophenyl)borane (BCF) was added for ${ }^{1} \mathrm{H}-\mathrm{NMR}$ measurements. This resulted in well-resolved signals in the ${ }^{1} \mathrm{H}$ NMR spectrum. ${ }^{1} \mathrm{H}$ NMR (400 $\left.\mathbf{~ M H z}, \mathbf{C D C l}_{3}\right): \delta 13.53(\mathrm{~s}, 1 \mathrm{H}), 7.71(\mathrm{~s}, 8 \mathrm{H}), 7.52$ $(\mathrm{s}, 4 \mathrm{H}), 7.43-7.23(\mathrm{~m}, 8 \mathrm{H}), 7.21(\mathrm{~s}, 2 \mathrm{H}), 7.13\left(\mathrm{~d},{ }^{3} \mathrm{~J}_{\mathrm{HH}}=7.8 \mathrm{~Hz}, 2 \mathrm{H}\right), 6.47(\mathrm{~s}, 2 \mathrm{H}), 4.15$ (brs, 2H), 3.31 (hept, $\left.{ }^{3} J_{H H}=6.8 \mathrm{~Hz}, 2 \mathrm{H}\right), 1.76\left(\mathrm{~d},{ }^{3} J_{\mathrm{HH}}=8.6 \mathrm{~Hz}, 6 \mathrm{H}\right), 1.27$ (d, $\left.{ }^{3} J_{\mathrm{HH}}=6.8 \mathrm{~Hz}, 6 \mathrm{H}\right), 1.23\left(\mathrm{~d},{ }^{3} \mathrm{~J}_{\mathrm{HH}}=6.7 \mathrm{~Hz}, 6 \mathrm{H}\right), 0.93\left(\mathrm{~d},{ }^{3} \mathrm{~J}_{\mathrm{HH}}=6.6 \mathrm{~Hz}, 6 \mathrm{H}\right), 0.87(\mathrm{~s}$, 6H). ${ }^{19} \mathrm{~F}$ NMR (376 MHz, $\mathrm{CD}_{2} \mathrm{Cl}_{2}$ ): $\delta-62.75 .{ }^{13} \mathrm{C}$ NMR (101 $\mathbf{M H z}, \mathrm{CD}_{2} \mathrm{Cl}_{2}$ ): $\delta 319.7$, 179.7, $162.2\left(\mathrm{q},{ }^{1} \mathrm{~J}_{\mathrm{CB}}=49.7 \mathrm{~Hz}, \mathrm{C}_{\mathrm{ipso}}, \mathrm{B}\left(\mathrm{Ar}^{\mathrm{F}}\right)_{4}\right), 151.5,145.7,144.2,135.2\left(\mathrm{~B}\left(\operatorname{Ar}^{\mathrm{F}}\right)_{4}\right)$, 129.5, $129.3\left(q q,{ }^{2} J_{C F}=31.9 \mathrm{~Hz},{ }^{3} J_{C B}=3.3 \mathrm{~Hz}, B\left(\operatorname{Ar}^{F}\right)_{4}\right), 127.7,126.5,125.0$ (q, $\left.{ }^{1} J_{C F}=272.8 \mathrm{~Hz}, C F_{3} B\left(\mathrm{Ar}^{\mathrm{F}}\right)_{4}\right), 124.6,119.4,117.9\left(\mathrm{~B}\left(\mathrm{Ar}^{\mathrm{F}}\right)_{4}\right), 110.4,56.0,54.8,30.3$, 
29.9, 29.3, 25.2, 24.0, 23.2, 22.6, 3.5.. Elemental analysis (\%) calcd. for $\mathrm{C}_{85} \mathrm{H}_{78} \mathrm{BF}_{24} \mathrm{MoN}_{3} \mathrm{O}$ : C 54.31, H 4.23, N 4.59; found: C 54.29, H 4.297, N 4.52.

Synthesis of I23: Mo-4.1 (150 mg, $0.26 \mathrm{mmol}$ ) was dissolved in $\mathrm{CH}_{2} \mathrm{Cl}_{2}$. A solution of $\mathrm{N}, \mathrm{N}$-dimethylanilinium $\mathrm{B}\left(\mathrm{ArF}^{\mathrm{F}}\right)_{4}(272 \mathrm{mg}, 0.26 \mathrm{mmol})$ in diethyl ether $(4 \mathrm{~mL})$ was added and the mixture was stirred at room temperature for one hour. The solvent was removed and the residue was washed with $n$-pentane several times. The resuling precipitate was removed by filtration and crystallized from a mixture of dichloromethane, diethyl ether and $n$-pentane to provide $\mathbf{1 2 3}$ in $80 \%$ yield. ${ }^{1} \mathbf{H}$ NMR (400 MHz, $\left.\mathrm{CDCl}_{3}\right): \delta 13.64(\mathrm{~s}, 1 \mathrm{H}), 7.72(\mathrm{~s}, 8 \mathrm{H}), 7.54(\mathrm{~s}, 4 \mathrm{H}), 7.29-6.80(\mathrm{~m}, 9 \mathrm{H}), 6.44$ $(\mathrm{s}, 2 \mathrm{H}), 4.59\left(\mathrm{hept},{ }^{3} \mathrm{~J}_{\mathrm{HH}}=6.6 \mathrm{~Hz}, 2 \mathrm{H}\right), 1.70(\mathrm{~s}, 3 \mathrm{H}), 1.57(\mathrm{~s}, 3 \mathrm{H}), 1.38\left(\mathrm{~d},{ }^{3} \mathrm{~J}_{\mathrm{HH}}=6.6 \mathrm{~Hz}\right.$, $6 \mathrm{H}), 1.16(\mathrm{~s}, 9 \mathrm{H}), 1.08(\mathrm{~s}, 6 \mathrm{H}) .{ }^{19} \mathrm{~F}$ NMR (376 MHz, CDCl $) \delta-62.32(\mathrm{~s}, 24 \mathrm{~F}$, $\left.\mathrm{B}\left(\mathrm{Ar}^{\mathrm{F}}\right)_{4}\right){ }^{13} \mathrm{C}$ NMR $\left(101 \mathrm{MHz}, \mathrm{CDCl}_{3}\right): \delta 324.6,172.0,161.8\left(\mathrm{q},{ }^{1} J_{C B}=49.8 \mathrm{~Hz}, \mathrm{C}_{\text {ipso }}\right.$ $\left.\mathrm{B}\left(\mathrm{Ar}^{\mathrm{F}}\right)_{4}\right), 147.6,134.9\left(\mathrm{~B}\left(\mathrm{Ar}^{\mathrm{F}}\right)_{4}\right), 129.1\left(\mathrm{qq},{ }^{2} J_{C F}=31.9 \mathrm{~Hz},{ }^{3} J_{\mathrm{CB}}=3.0 \mathrm{~Hz}, \mathrm{~B}\left(\operatorname{Ar}^{\mathrm{F}}\right)_{4}\right)$, 128.8, 127.0, 126.5, 124.7 (q, $\left.{ }^{1} J_{C F}=272.3 \mathrm{~Hz}, \mathrm{CF}_{3} \mathrm{~B}\left(\mathrm{ArF}^{\mathrm{F}}\right)_{4}\right), 121.0,117.7\left(\mathrm{~B}\left(\mathrm{Ar}^{\mathrm{F}}\right)_{4}\right)$, 108.0, 74.2, 56.0, 32.3, 31.5, 30.3, 23.3, 22.8. Elemental analysis (\%) calcd. for $\mathrm{C}_{59} \mathrm{H}_{53} \mathrm{BF}_{24} \mathrm{MoN}_{4}$ : C 51.32, H 3.87, N 4.07; found: C 51.41, H 3.909, N 4.05.

Synthesis of I28: 124 (64.4 mg, $0.04 \mathrm{mmol})$ was dissolved in $\mathrm{CH}_{2} \mathrm{Cl}_{2}$ and a solution of $\mathrm{HMTOH}\left(14.5 \mathrm{mg}, 0.04 \mathrm{mmol}\right.$ ) in $\mathrm{CH}_{2} \mathrm{Cl}_{2}$ was added at $-35^{\circ} \mathrm{C}$. The solution was stirred for three hours and the solvent was removed. The resulting yellow foam was twice co-evaporated with pentane and then stirred with pentane until a solid formed. Pentane was decanted (removal of pyrrole) and the remaining yellow solid was crystallized from $\mathrm{CH}_{2} \mathrm{Cl}_{2}$, diethyl ether and pentane to afford $\mathbf{I 2 8}$ in quantitative yield. If acetonitrile was used in the synthesis or during purification, $\mathbf{1 2 8}$ contains 1 equiv. of acetonitrile. NMR spectra were measured for $128 \times \mathrm{MeCN}$, whereas elemental analysis is for I28. ${ }^{1} \mathrm{H}$ NMR (400 MHz, $\left.\mathrm{CD}_{2} \mathrm{Cl}_{2}\right): \delta 12.48\left(\mathrm{~s}, 1 \mathrm{H},{ }^{1} \mathrm{~J}_{\mathrm{CH}}=122.5 \mathrm{~Hz}\right.$, syn), $7.74(\mathrm{br}$ 
s, 8H, B(ArF $\left.)_{4}\right), 7.57\left(\mathrm{br} \mathrm{s}, 4 \mathrm{H}, \mathrm{B}\left(\mathrm{Ar}^{\mathrm{F}}\right)_{4}\right), 7.37-7.28(\mathrm{~m}, 5 \mathrm{H}), 7.26-7.22(\mathrm{~m}, 1 \mathrm{H}), 7.15(\mathrm{~s}$, 2H), 7.09-6.96 (m, 6H), 6.91-6.66 (m, 3H), $5.97\left(\mathrm{~d},{ }^{3} \mathrm{~J}_{\mathrm{HH}}=7.84 \mathrm{~Hz}, 1 \mathrm{H}\right), 3.93$ (hept, $2 \mathrm{H}$, $\left.{ }^{3} \mathrm{~J}_{\mathrm{HH}}=6.5 \mathrm{~Hz}\right), 2.31(\mathrm{~s}, 6 \mathrm{H}), 2.00(\mathrm{~s}, 12 \mathrm{H}), 1.76(\mathrm{~s}, 3 \mathrm{H}), 1.68(\mathrm{~s}, 3 \mathrm{H}), 1.46(\mathrm{~s}, 3 \mathrm{H}) ; 1.28$ $(\mathrm{s}, 9 \mathrm{H}), 1.26\left(\mathrm{~d}, 6 \mathrm{H},{ }^{3} \mathrm{~J}_{\mathrm{HH}}=6.5 \mathrm{~Hz}\right), 0.77\left(\mathrm{~d}, 6 \mathrm{H},{ }^{3} \mathrm{~J}_{\mathrm{HH}}=6.5 \mathrm{~Hz}\right) .{ }^{19} \mathrm{~F} \mathrm{NMR}(376 \mathrm{MHz}$, $\left.\mathrm{CD}_{2} \mathrm{Cl}_{2}\right) \delta-65.67\left(\mathrm{~B}(\mathrm{ArF})_{4}\right) \cdot{ }^{13} \mathrm{C}$ NMR $\left(101 \mathrm{MHz}, \mathrm{C}_{6} \mathrm{D}_{6}\right)^{*}: \delta 177.6,162.3\left(\mathrm{q},{ }^{1} \mathrm{~J}_{\mathrm{CB}}=\right.$ 49.8 Hz, $\left.\mathrm{C}_{\text {ipso }}, \mathrm{B}\left(\mathrm{Ar}^{\mathrm{F}}\right)_{4}\right), 160.9,154.9,145.1,144.6,138.0,137.6,137.2,137.1,137.0$, $135.4\left(\mathrm{~B}\left(\mathrm{Ar}^{\mathrm{F}}\right)_{4}\right), 132.1,131.9,131.5,130.1,129.8,129.6,129.2,129.1,128.9,127.5$, 127.3, 127.2, 127.0, $125.16\left(\mathrm{q},{ }^{1} \mathrm{~J}_{\mathrm{CF}}=272.4 \mathrm{~Hz}, \mathrm{CF}_{3} \mathrm{~B}\left(\mathrm{Ar}^{\mathrm{F}}\right)_{4}\right)^{\star *}, 121.8,119.72,118.0$ $\left(\mathrm{B}\left(\mathrm{Ar}^{\mathrm{F}}\right)_{4}\right), 58.7,36.0,31.2,31.0,30.2,29.3,24.5,24.2,21.9,21.3,20.6,3.41\left(\mathrm{CH}_{3}\right.$, $\mathrm{MeCN})^{* * *}$. Elemental analysis (\%) calcd. for $\mathrm{C}_{85} \mathrm{H}_{78} \mathrm{BF}_{24} \mathrm{MoN}_{3} \mathrm{O}$ : C 59.35, H 4.57, $\mathrm{N}$ 2.44; found: C 59.08, H 4.662, N 2.62. * The alkylidene carbon signal was not clearly visible in the ${ }^{13} \mathrm{C}$ NMR spectrum, even though $80 \mathrm{mg}$ of catalyst were used and the spectrum was measured from 0 to 400 ppm. However, a small peak at 324.9 ppm was observed. ** The fourth signal of the quartet is not observable due to overlapping with other aromatic signals. ${ }^{* *}$ The signal of the nitrile carbon most probably overlaps with the broad signal at $118.0 \mathrm{ppm}$.

Synthesis of I29: I22 (200 mg, $0.14 \mathrm{mmol})$ was dissolved in $\mathrm{CH}_{2} \mathrm{Cl}_{2}(5 \mathrm{~mL})$ and a solution of $\mathrm{HMTOH}(46 \mathrm{mg}, 0.14 \mathrm{mmol})$ in $\mathrm{CH}_{2} \mathrm{Cl}_{2}(2 \mathrm{~mL})$ was added at room temperature. The solution was stirred overnight. The solvent was removed, and the residue was washed with $n$-pentane several times until the washing phase remained colorless. $n$-Pentane was decanted, and the remaining yellow solid was crystallized from $\mathrm{CH}_{2} \mathrm{Cl}_{2}$, diethyl ether and pentane to afford $\mathrm{I} 29$ in $76 \%$ yield. ${ }^{1} \mathrm{H}$ NMR $(400 \mathrm{MHz}$, $\left.\mathrm{CD}_{2} \mathrm{Cl}_{2}\right): \delta 12.41(\mathrm{~s}, 1 \mathrm{H}), 7.77(\mathrm{~s}, 8 \mathrm{H}), 7.59(\mathrm{~s}, 4 \mathrm{H}), 7.34-7.16(\mathrm{~m}, 8 \mathrm{H}), 7.12-6.94$ $(\mathrm{m}, 7 \mathrm{H}), 6.90(\mathrm{~s}, 2 \mathrm{H}), 4.01\left(\mathrm{hept},{ }^{3} \mathrm{~J}_{\mathrm{HH}}=6.6 \mathrm{~Hz}, 2 \mathrm{H}\right), 2.31(\mathrm{~s}, 6 \mathrm{H}), 1.98(\mathrm{~s}, 6 \mathrm{H}), 1.92(\mathrm{~s}$, $6 \mathrm{H}), 1.70(\mathrm{~s}, 6 \mathrm{H}), 1.51(\mathrm{~s}, 6 \mathrm{H}), 1.31\left(\mathrm{~d},{ }^{3} \mathrm{~J}_{\mathrm{HH}}=6.6 \mathrm{~Hz}, 6 \mathrm{H}\right), 1.06\left(\mathrm{~d},{ }^{3} \mathrm{~J}_{\mathrm{HH}}=6.6 \mathrm{~Hz}, 6 \mathrm{H}\right)$. 
${ }^{19} \mathrm{~F}$ NMR (376 MHz, $\left.\mathrm{CD}_{2} \mathrm{Cl}_{2}\right) \delta-62.77 .{ }^{13} \mathrm{C}$ NMR (101 MHz, $\mathrm{CD}_{2} \mathrm{Cl}_{2}$ ): $\delta 311.8,173.3$ $162.4\left(\mathrm{q},{ }^{1} \mathrm{~J}_{C B}=49.8 \mathrm{~Hz}, \mathrm{C}_{\mathrm{ipso}} \mathrm{B}\left(\mathrm{Ar}^{\mathrm{F}}\right)_{4}\right), 158.5,156.1,146.1,138.3,137.4,136.4,135.9$, $135.4,132.2,131.4,129.8,129.6\left(q q,{ }^{2} J_{C F}=31.3 \mathrm{~Hz},{ }^{3} J_{C B}=2.8 \mathrm{~Hz}, \mathrm{~B}\left(\operatorname{Ar}^{\mathrm{F}}\right)_{4}\right), 129.5$, 129.4, 128.8, 127.7, 125.4, $125.2\left(\mathrm{q},{ }^{1} \mathrm{~J}_{\mathrm{CF}}=273.0 \mathrm{~Hz}, \mathrm{CF}_{3} \mathrm{~B}\left(\mathrm{Ar}^{\mathrm{F}}\right)_{4}\right), 121.3,118.1,57.6$, $55.4,32.0,28.5,24.0,23.5,21.4,21.4,20.7,19.4 .=311.82,173.28,163.12,162.63$, $162.38\left(q,{ }^{1} J_{C B}=49.8 \mathrm{~Hz}\right), 162.13,161.64,158.48,156.12,146.12,138.27,137.36$, 136.43, 135.87, 135.86, $135.42\left(B\left(\mathrm{Ar}^{\mathrm{F}}\right)_{4}\right), 132.15,131.45,129.77,129.62$ (qq, $\left.{ }^{2} J_{C F}=31.3 \mathrm{~Hz}, \quad{ }^{3} J_{C B}=2.8 \mathrm{~Hz}\right), .129 .49,129.35,129.28,128.81,127.71,126.57$,

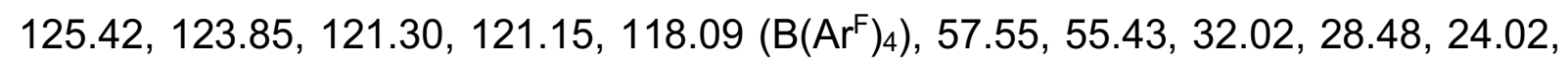
23.54, 21.41, 21.37, 20.68, 19.41. Elemental analysis (\%) calcd. for $\mathrm{C}_{83} \mathrm{H}_{74} \mathrm{BF}_{24} \mathrm{MoN}_{3} \mathrm{O}$ : C 58.91, H 4.41, N 2.48; found: C 59.20, H 4.692, N 2.53. 


\section{Spectra}

Polymerizations of DCMNBE

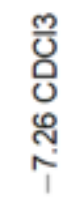

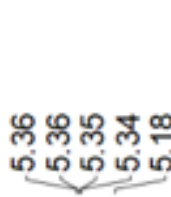

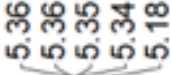

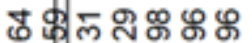

m

ষ্ণ

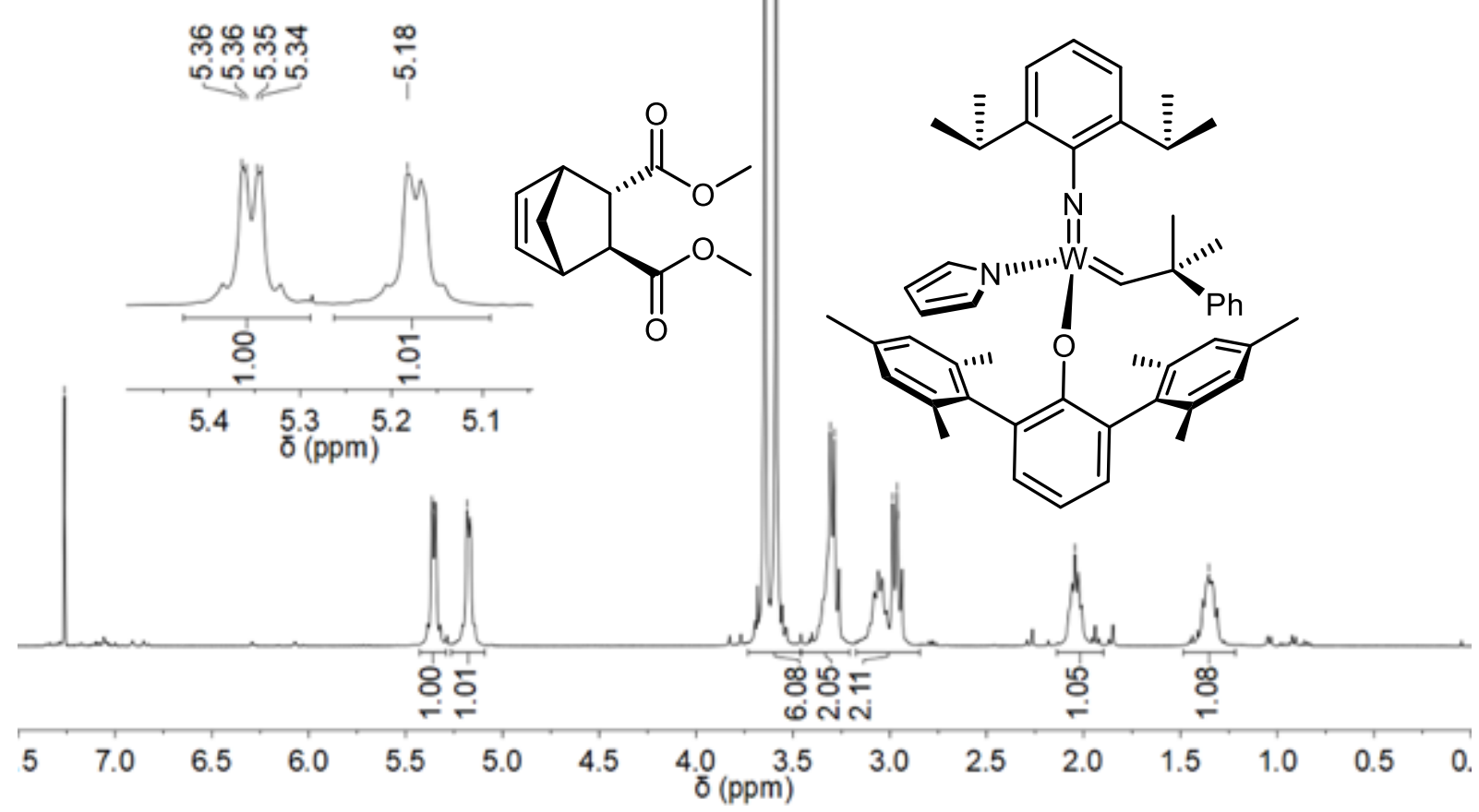

Figure S1: ${ }^{1} \mathrm{H}-\mathrm{NMR}$ spectrum $(400 \mathrm{MHz})$ of the polymerization of $\mathbf{M} 1$ using $\mathbf{~} 1$ in $\mathrm{CDCl}_{3}$. 


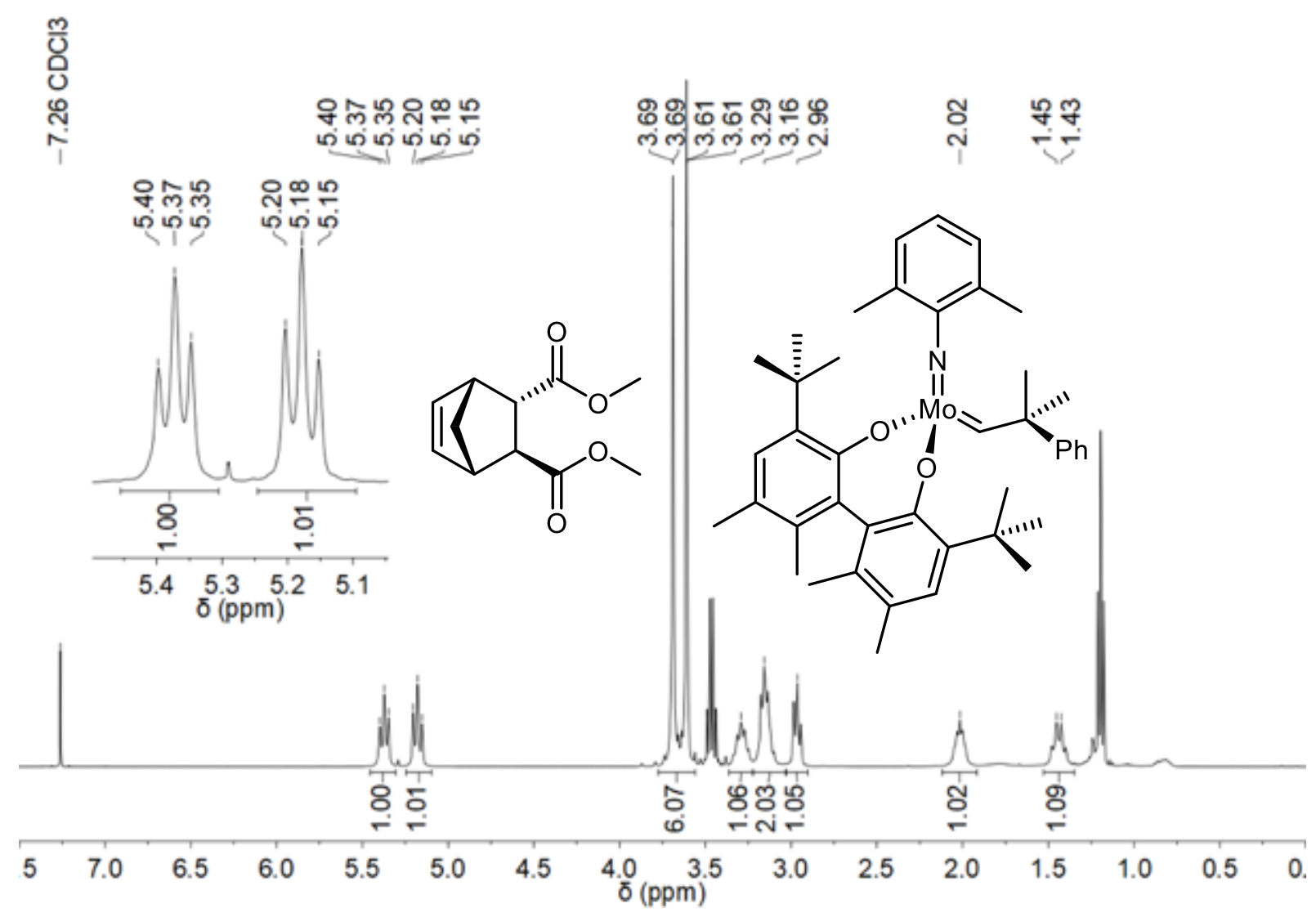

Figure S2: ${ }^{1} \mathrm{H}-\mathrm{NMR}$ spectrum $(400 \mathrm{MHz})$ of the polymerization of $\mathbf{M} \mathbf{1}$ using $\mathbf{I} \mathbf{2}$ in $\mathrm{CDCl}_{3}$.

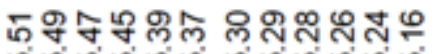

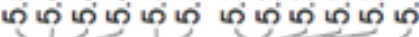

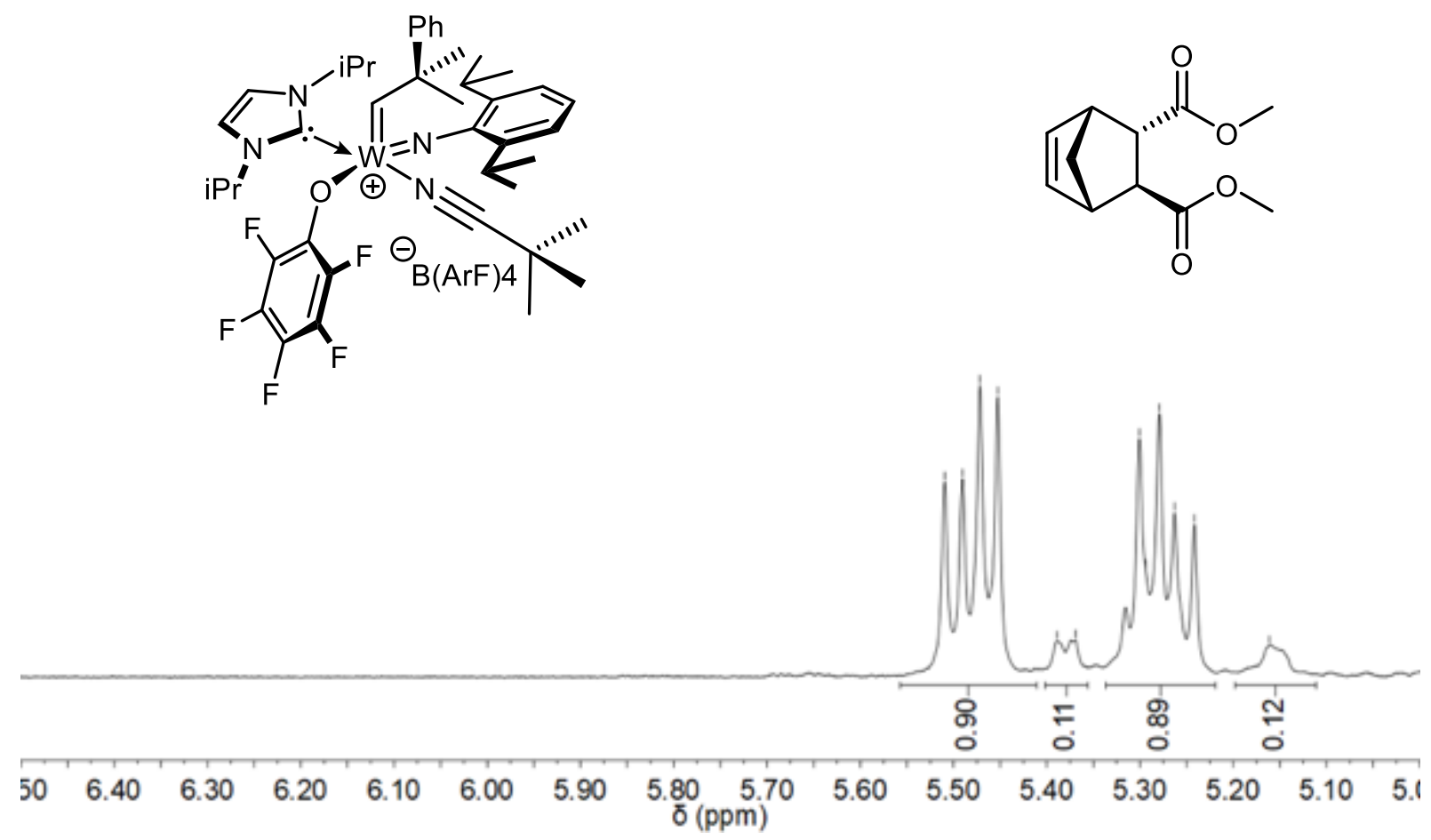

Figure S3: ${ }^{1} \mathrm{H}-\mathrm{NMR}$ spectrum $(400 \mathrm{MHz})$ of the polymerization of $\mathbf{M} 1$ using $\mathbf{I} 3$ in $\mathrm{CDCl}_{3}$. 


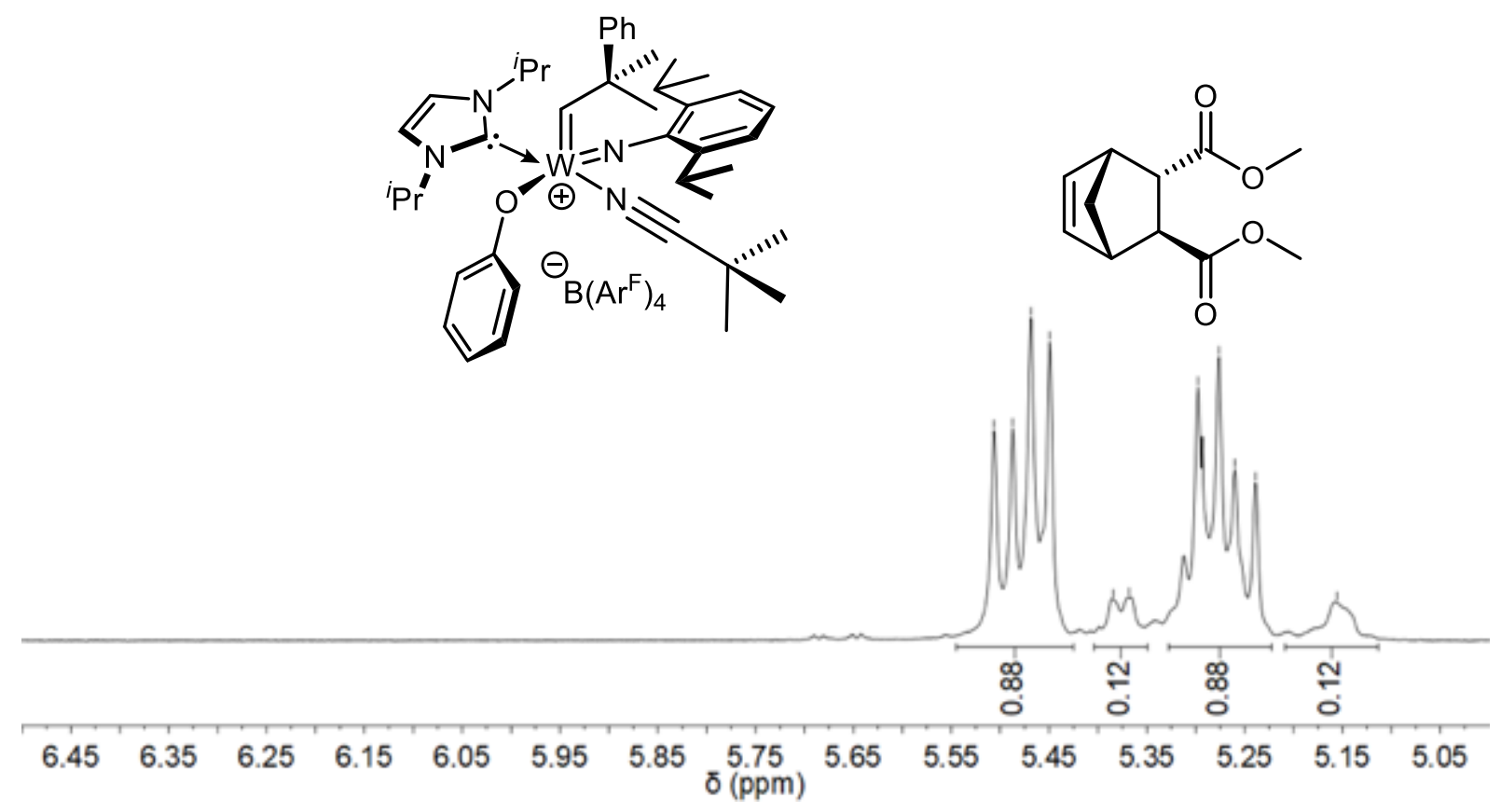

Figure S4: ${ }^{1} \mathrm{H}-\mathrm{NMR}$ spectrum $\left(400 \mathrm{MHz}\right.$ ) of the polymerization of $\mathbf{M} 1$ using $\mathbf{I} 4$ in $\mathrm{CDCl}_{3}$.

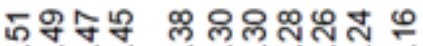

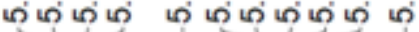

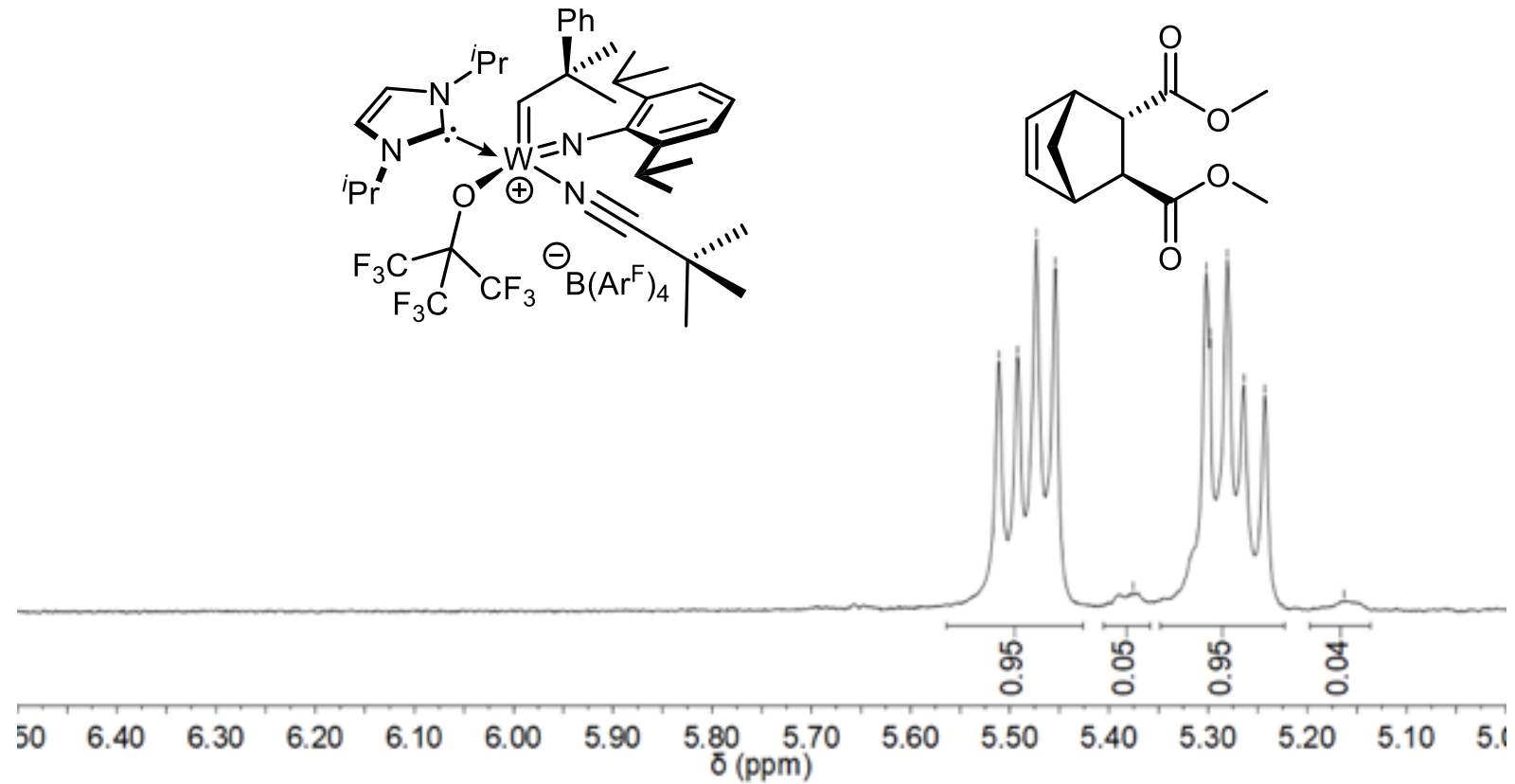

Figure S5: ${ }^{1} \mathrm{H}-\mathrm{NMR}$ spectrum (400 MHz) of the polymerization of $\mathbf{M} 1$ using $\mathbf{I 5}$ in $\mathrm{CDCl}_{3}$. 


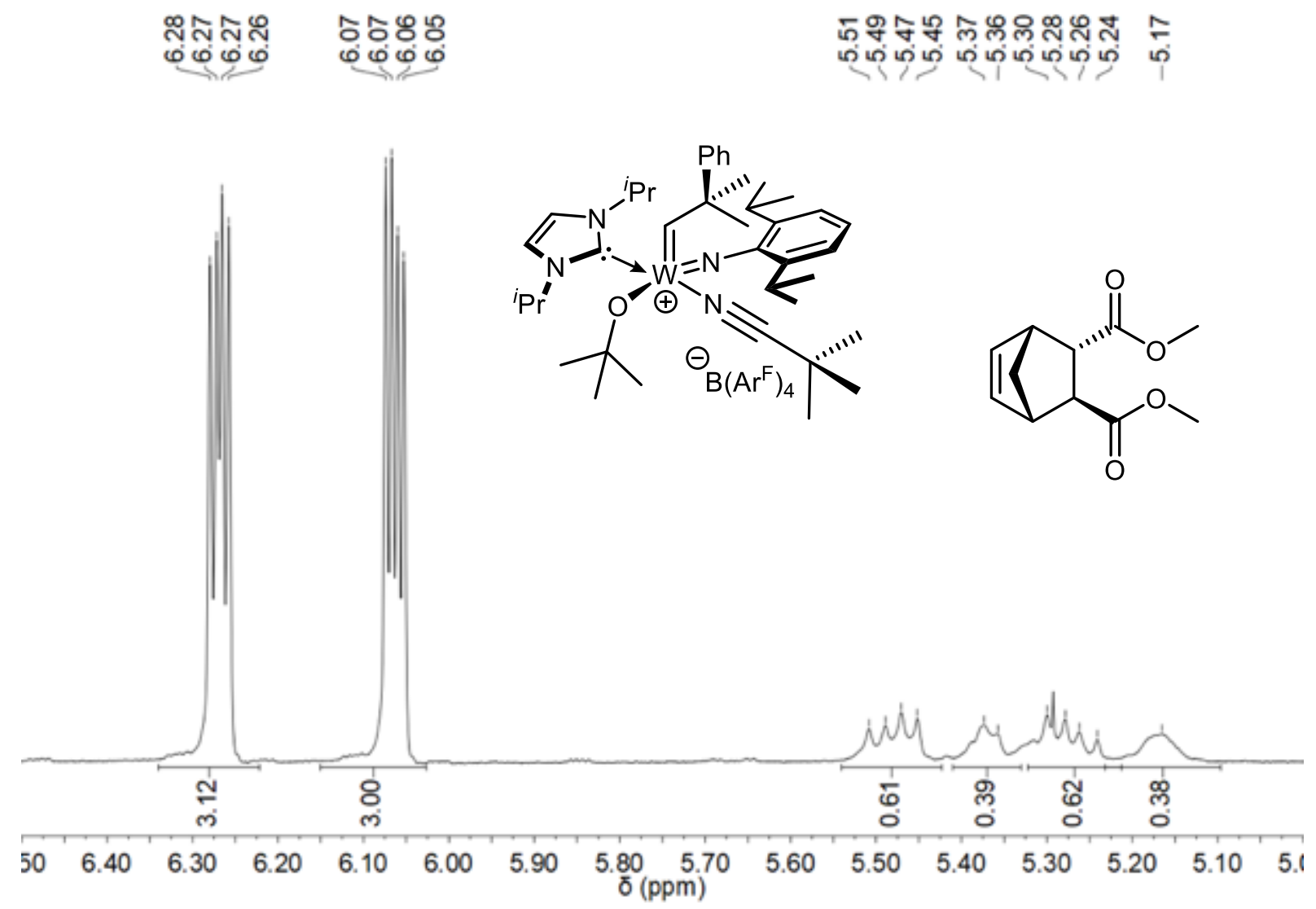

Figure S6: ${ }^{1} \mathrm{H}-\mathrm{NMR}$ spectrum $(400 \mathrm{MHz})$ of the polymerization of $\mathbf{M} 1$ using $\mathbf{I} 6$ in $\mathrm{CDCl}_{3}$.

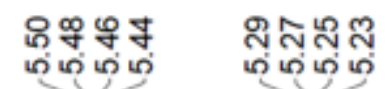

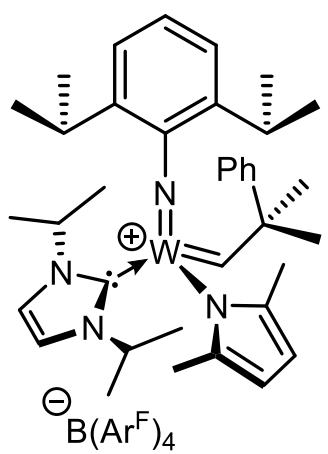<smiles>COC(=O)[C@H]1[C@H]2C=C[C@@H](C2)[C@H]1C(=O)OC</smiles>

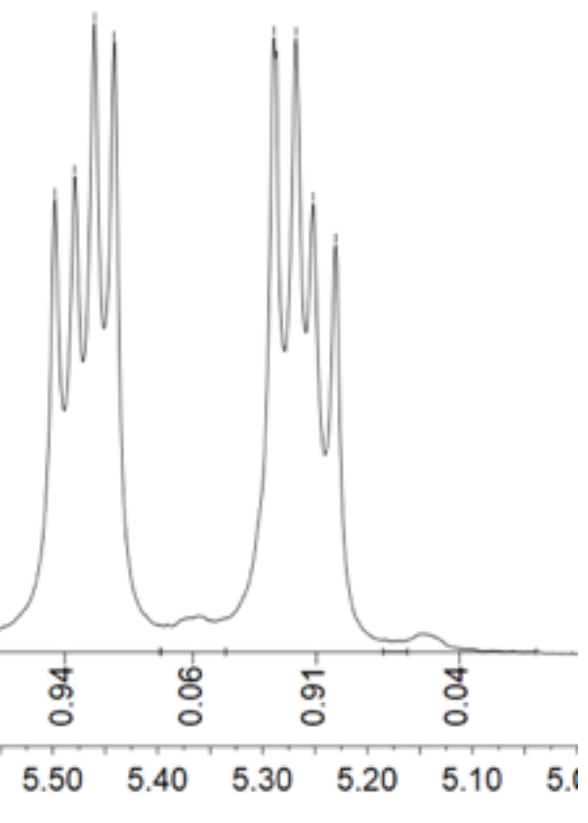

Figure S7: ${ }^{1} \mathrm{H}-\mathrm{NMR}$ spectrum $(400 \mathrm{MHz})$ of the polymerization of $\mathbf{M} \mathbf{1}$ using $\mathbf{I 7}$ in $\mathrm{CDCl}_{3}$. 


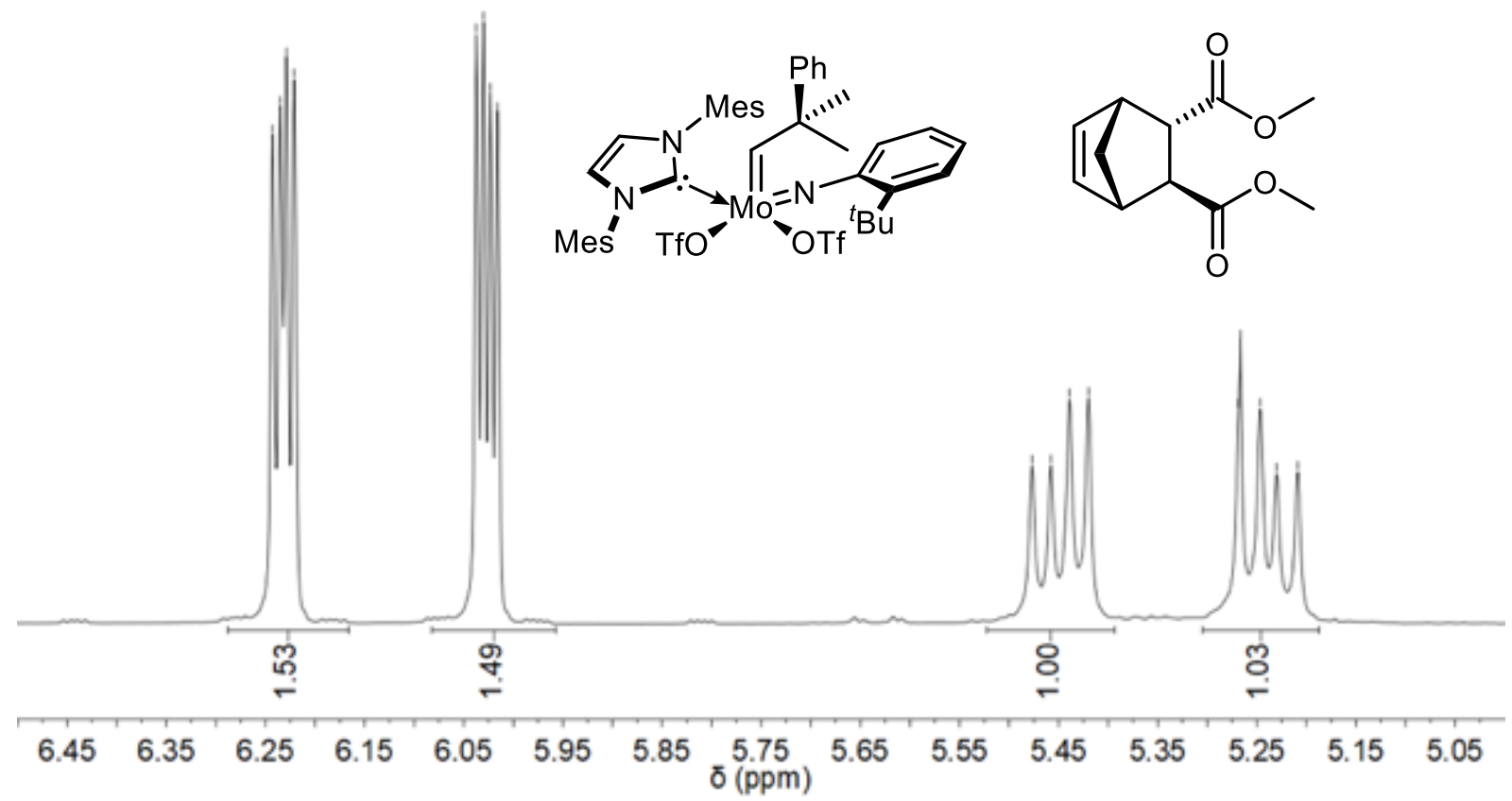

Figure S8: ${ }^{1} \mathrm{H}-\mathrm{NMR}$ spectrum $(400 \mathrm{MHz})$ of the polymerization of $\mathbf{M} 1$ using $\mathbf{I 8}$ in $\mathrm{CDCl}_{3}$.

\begin{tabular}{|c|}
\hline 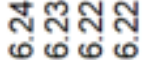 \\
\hline
\end{tabular}

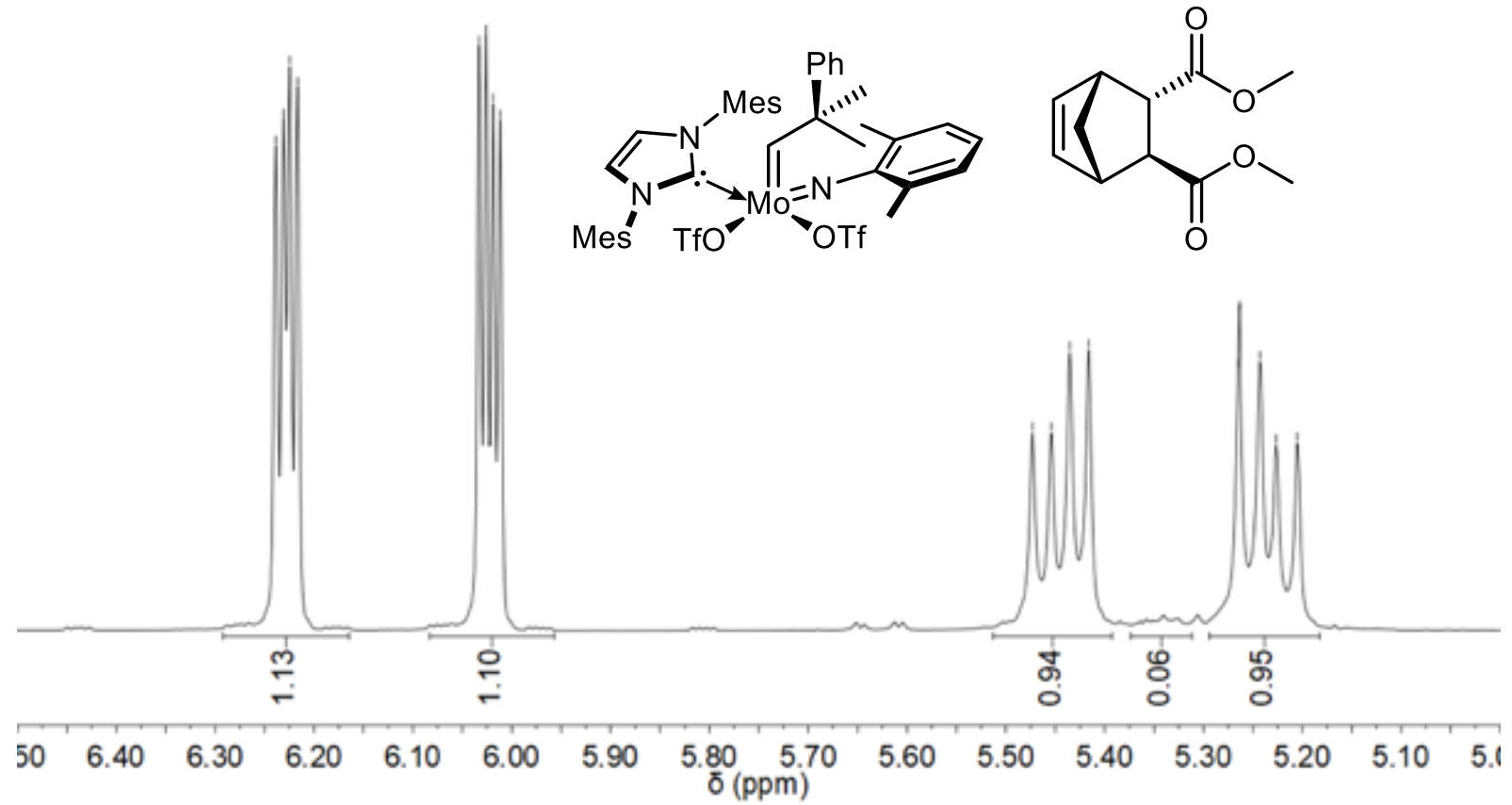

Figure S9: ${ }^{1} \mathrm{H}-\mathrm{NMR}$ spectrum $\left(400 \mathrm{MHz}\right.$ ) of the polymerization of $\mathbf{M} 1$ using 19 in $\mathrm{CDCl}_{3}$. 


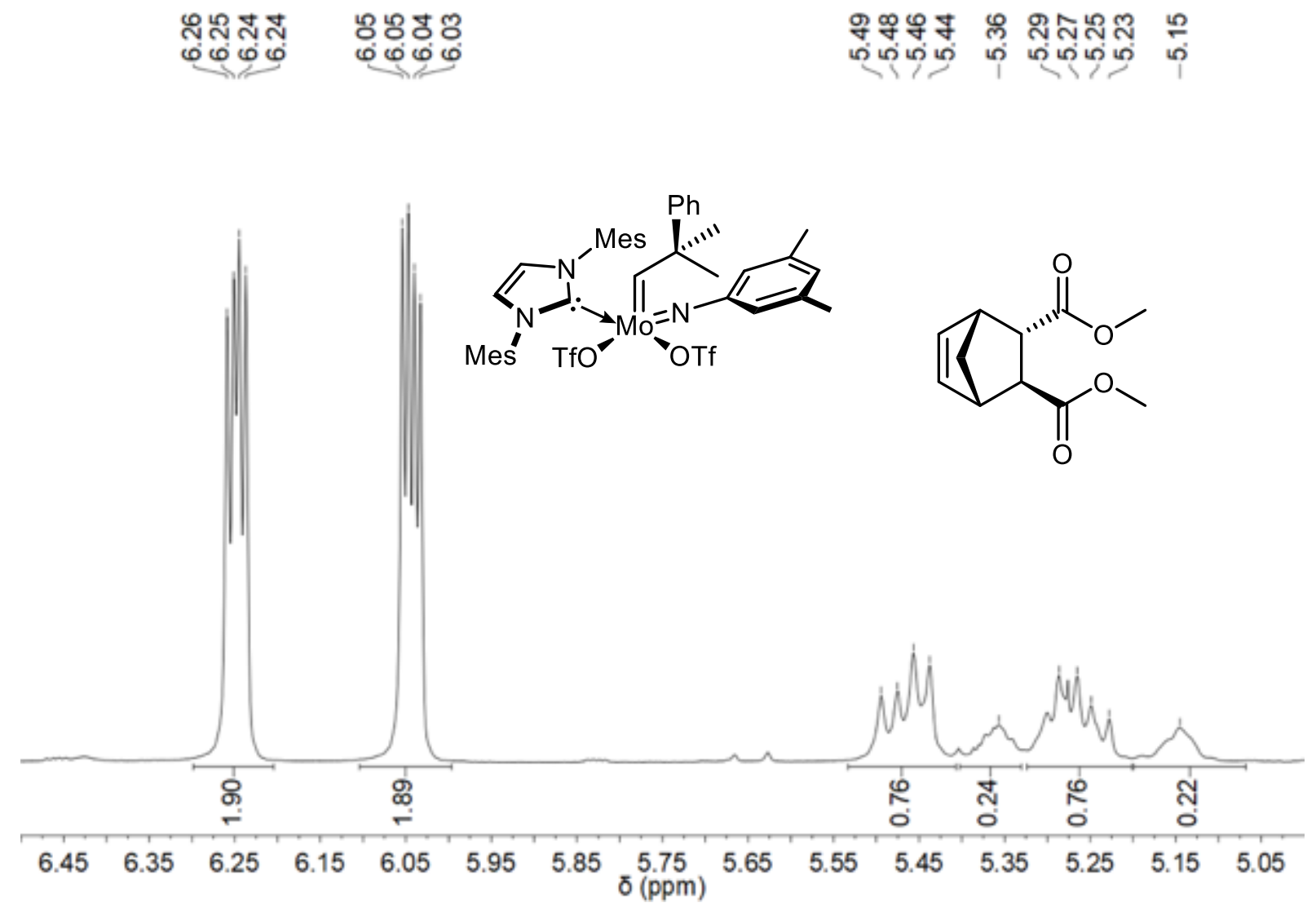

Figure S10: ${ }^{1} \mathrm{H}-\mathrm{NMR}$ spectrum $\left(400 \mathrm{MHz}\right.$ ) of the polymerization of $\mathbf{M} 1$ using $\mathbf{I 1 0}$ in $\mathrm{CDCl}_{3}$.

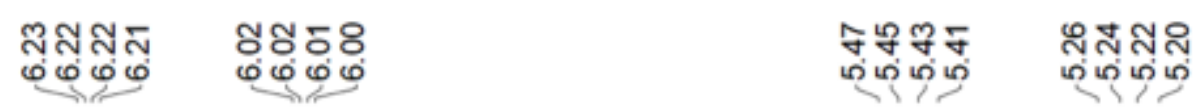

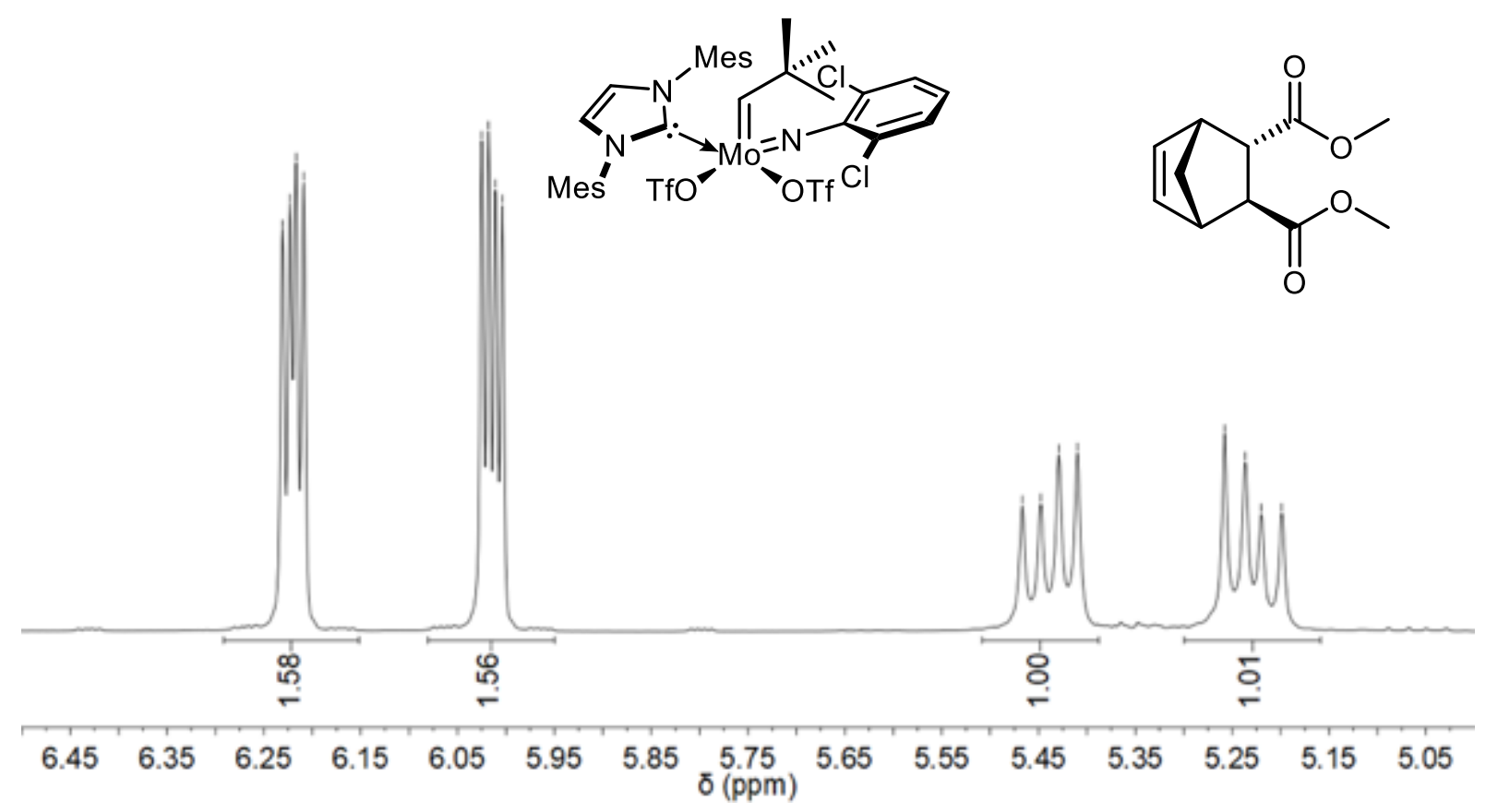

Figure S11: ${ }^{1} \mathrm{H}-\mathrm{NMR}$ spectrum $(400 \mathrm{MHz})$ of the polymerization of $\mathbf{M} 1$ using $\mathbf{I 1 1}$ in $\mathrm{CDCl}_{3}$. 


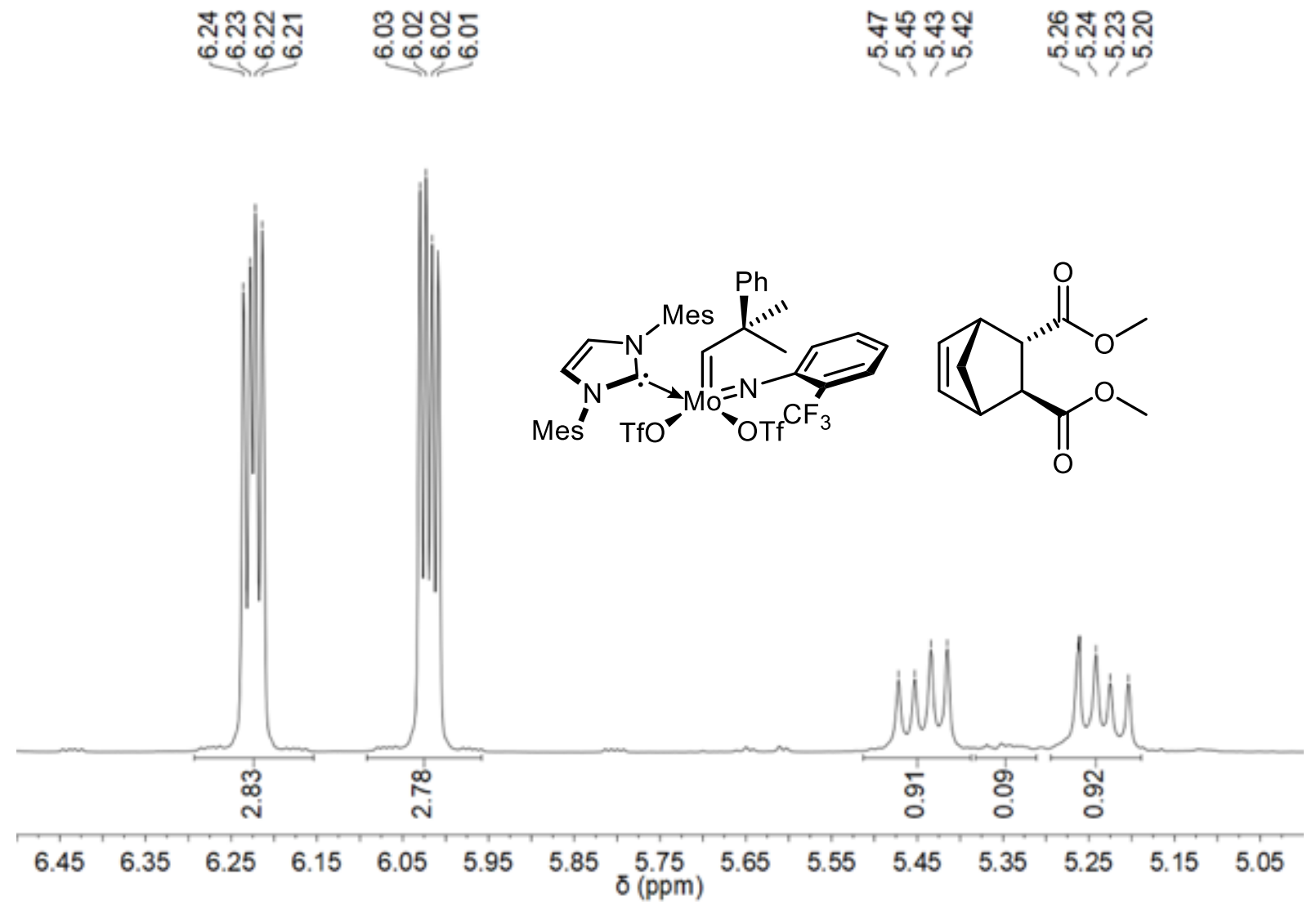

Figure S12: ${ }^{1} \mathrm{H}-\mathrm{NMR}$ spectrum $(400 \mathrm{MHz})$ of the polymerization of $\mathbf{M} 1$ using $\mathbf{I 1 2}$ in $\mathrm{CDCl}_{3}$.

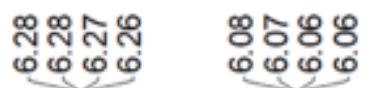

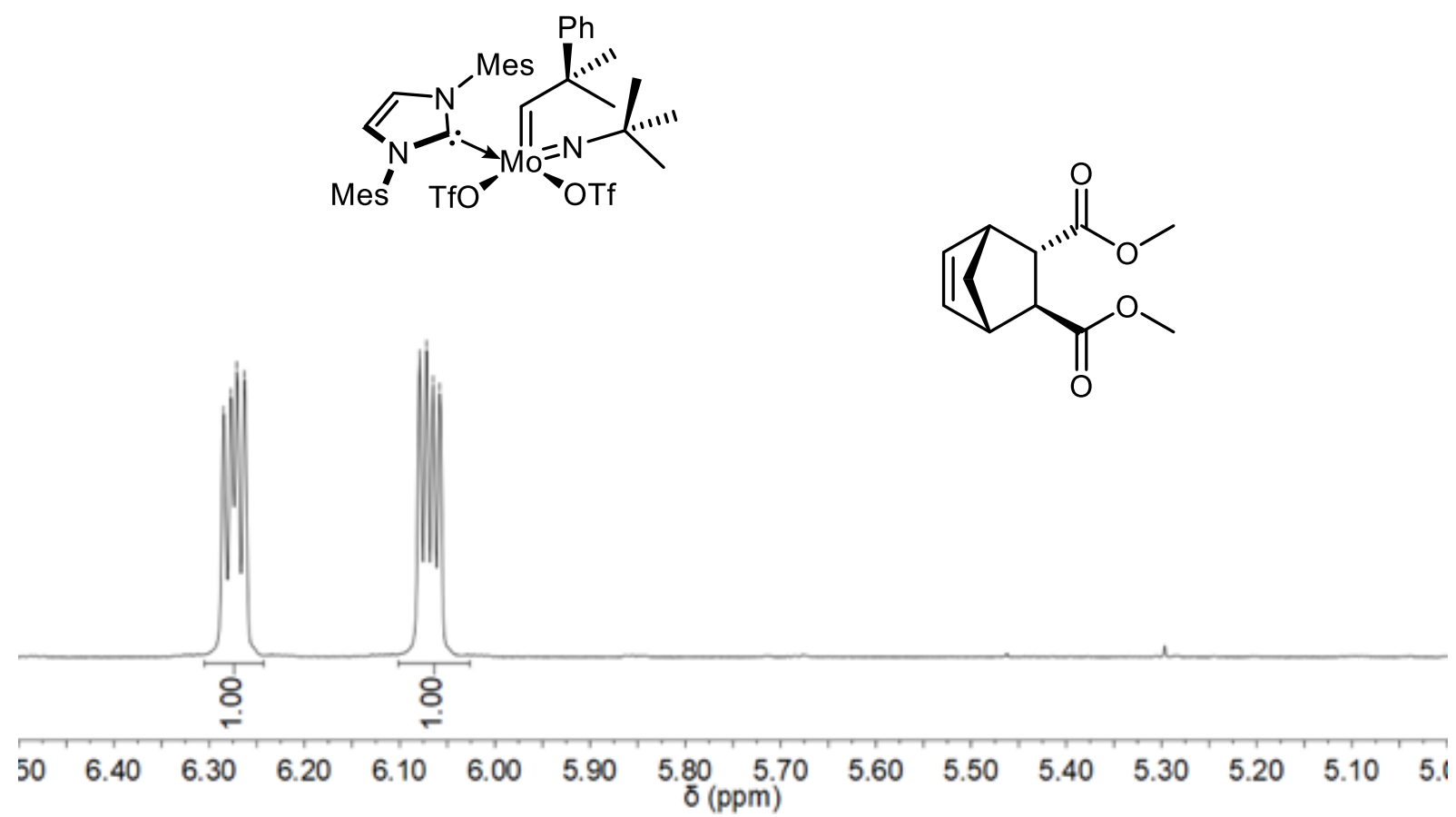

Figure S13: ${ }^{1} \mathrm{H}-\mathrm{NMR}$ spectrum $(400 \mathrm{MHz})$ of the polymerization of $\mathbf{M} 1$ using $\mathbf{I} 13$ in $\mathrm{CDCl}_{3}$. 


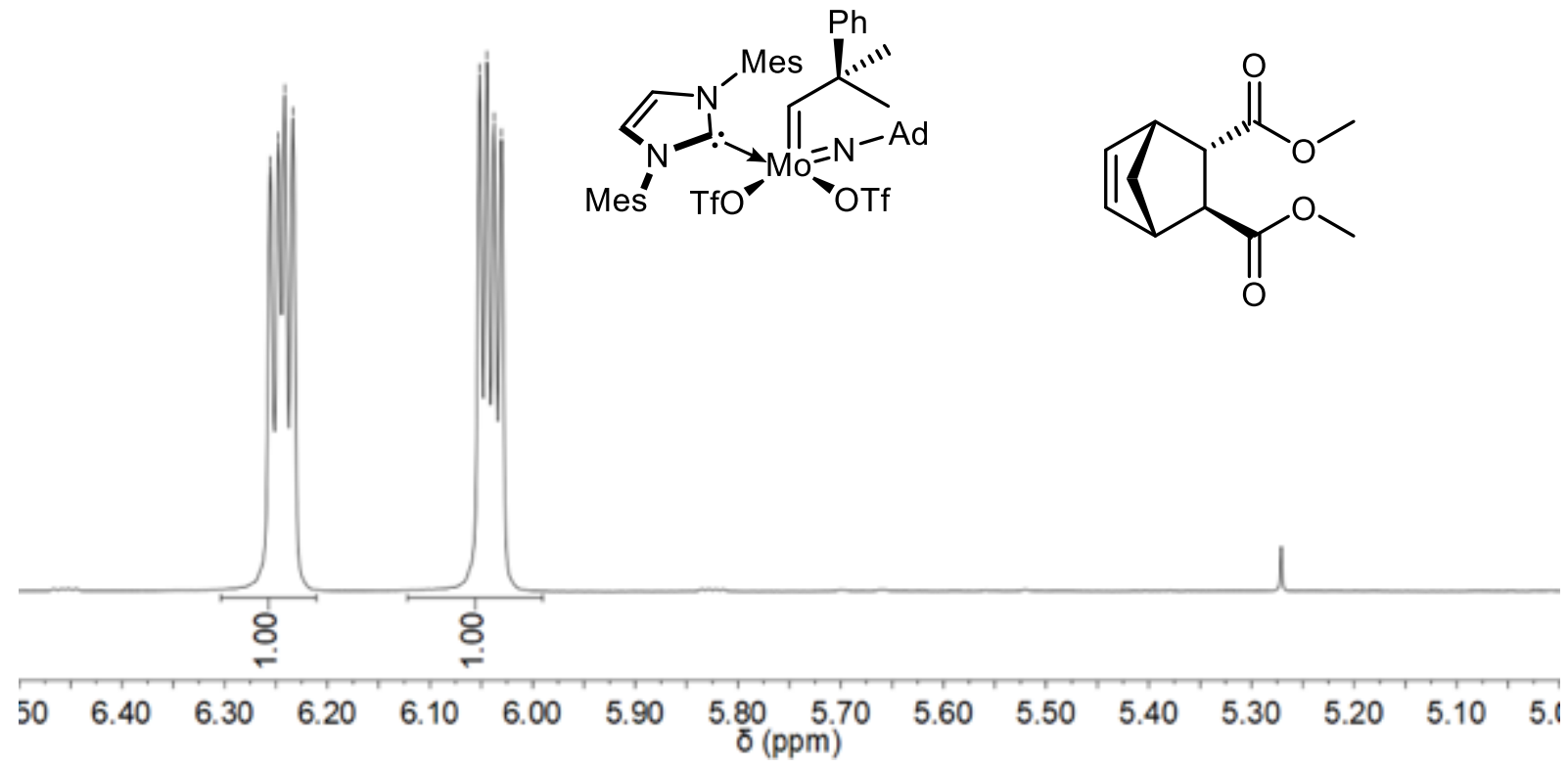

Figure S14: ${ }^{1} \mathrm{H}-\mathrm{NMR}$ spectrum $\left(400 \mathrm{MHz}\right.$ ) of the polymerization of $\mathbf{M} 1$ using $\mathbf{I 1 4}$ in $\mathrm{CDCl}_{3}$.

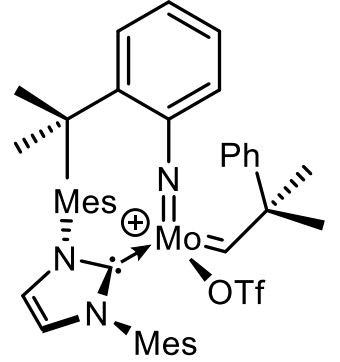<smiles>COC(=O)[C@H]1[C@H]2C=C[C@@H](C2)[C@H]1C(=O)OC</smiles>

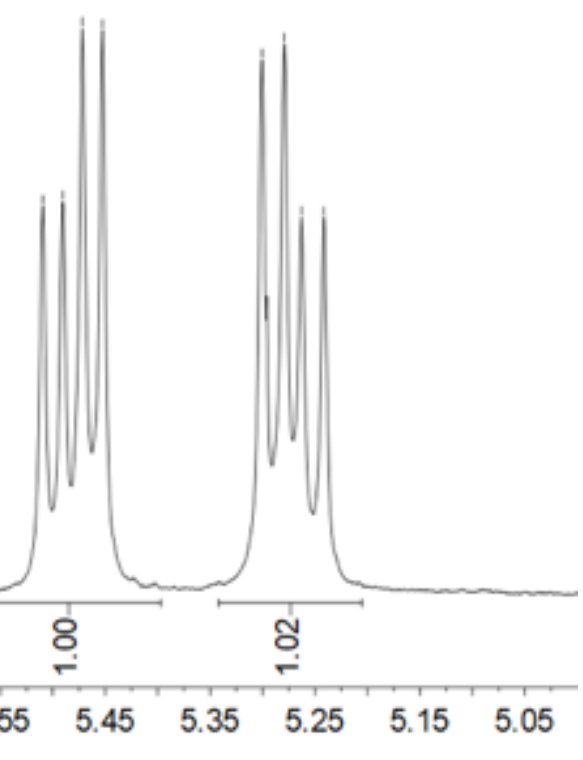

Figure S15: ${ }^{1} \mathrm{H}-\mathrm{NMR}$ spectrum $(400 \mathrm{MHz})$ of the polymerization of $\mathbf{M} 1$ using $\mathbf{I} 15$ in $\mathrm{CDCl}_{3}$. 


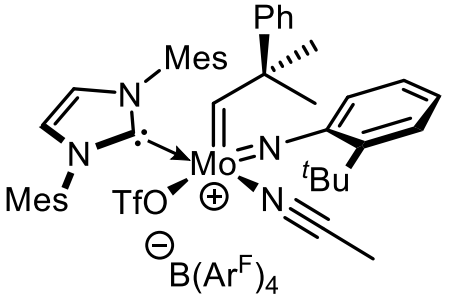<smiles>COC(=O)[C@H]1[C@H]2C=C[C@@H](C2)[C@H]1C(=O)OC</smiles>

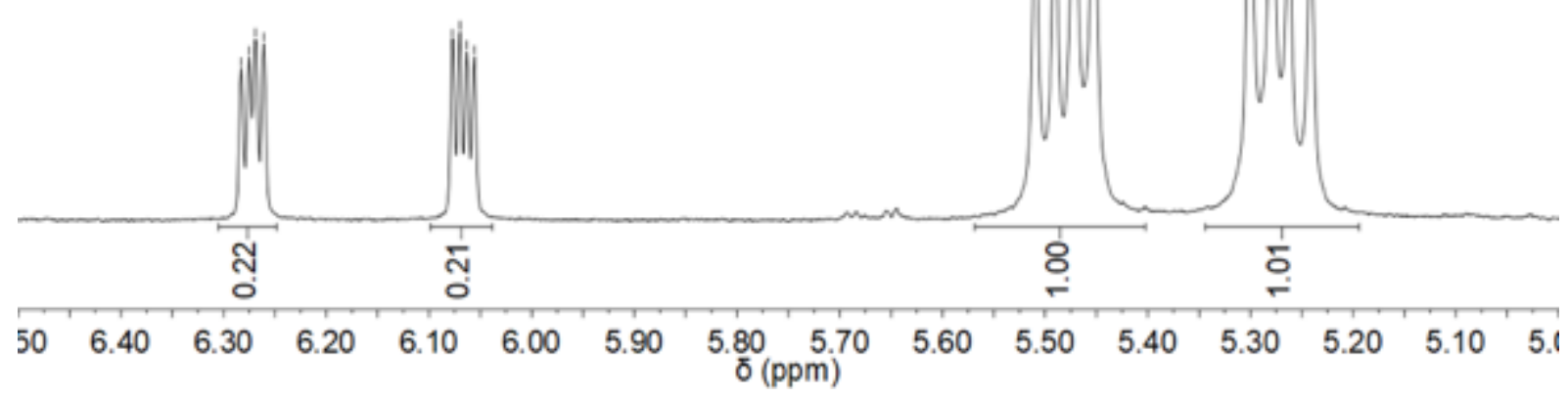

Figure S16: ${ }^{1} \mathrm{H}-\mathrm{NMR}$ spectrum (400 MHz) of the polymerization of $\mathbf{M} 1$ using I15-MeCN in $\mathrm{CDCl}_{3}$.

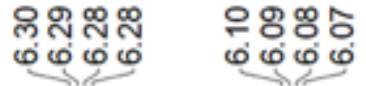

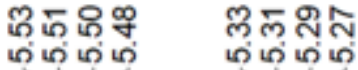

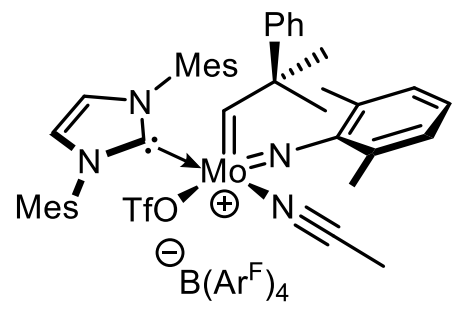<smiles>COC(=O)[C@H]1C2C=CC(C2)[C@H]1C(=O)OC</smiles>

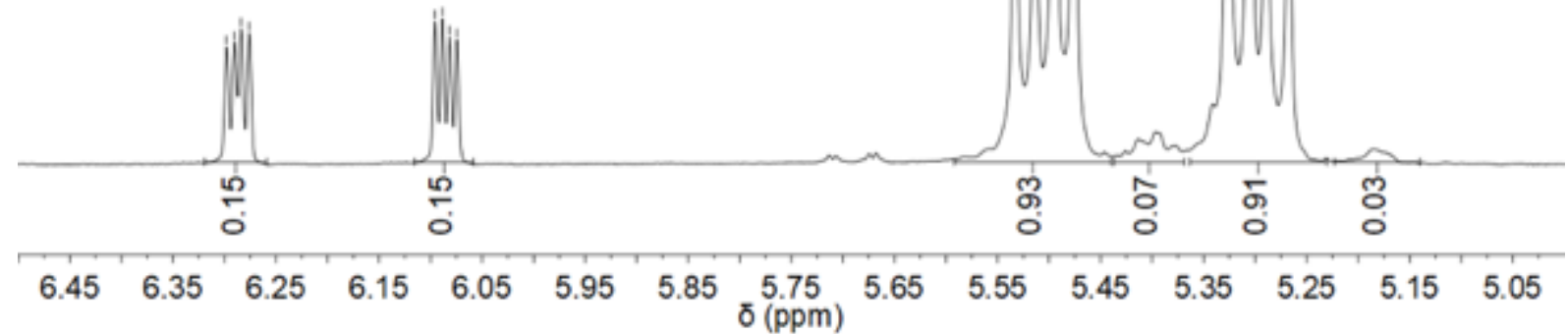

Figure S17: ${ }^{1} \mathrm{H}-\mathrm{NMR}$ spectrum $(400 \mathrm{MHz})$ of the polymerization of $\mathbf{M} 1$ using $\mathrm{I} 16$ in $\mathrm{CDCl}_{3}$. 


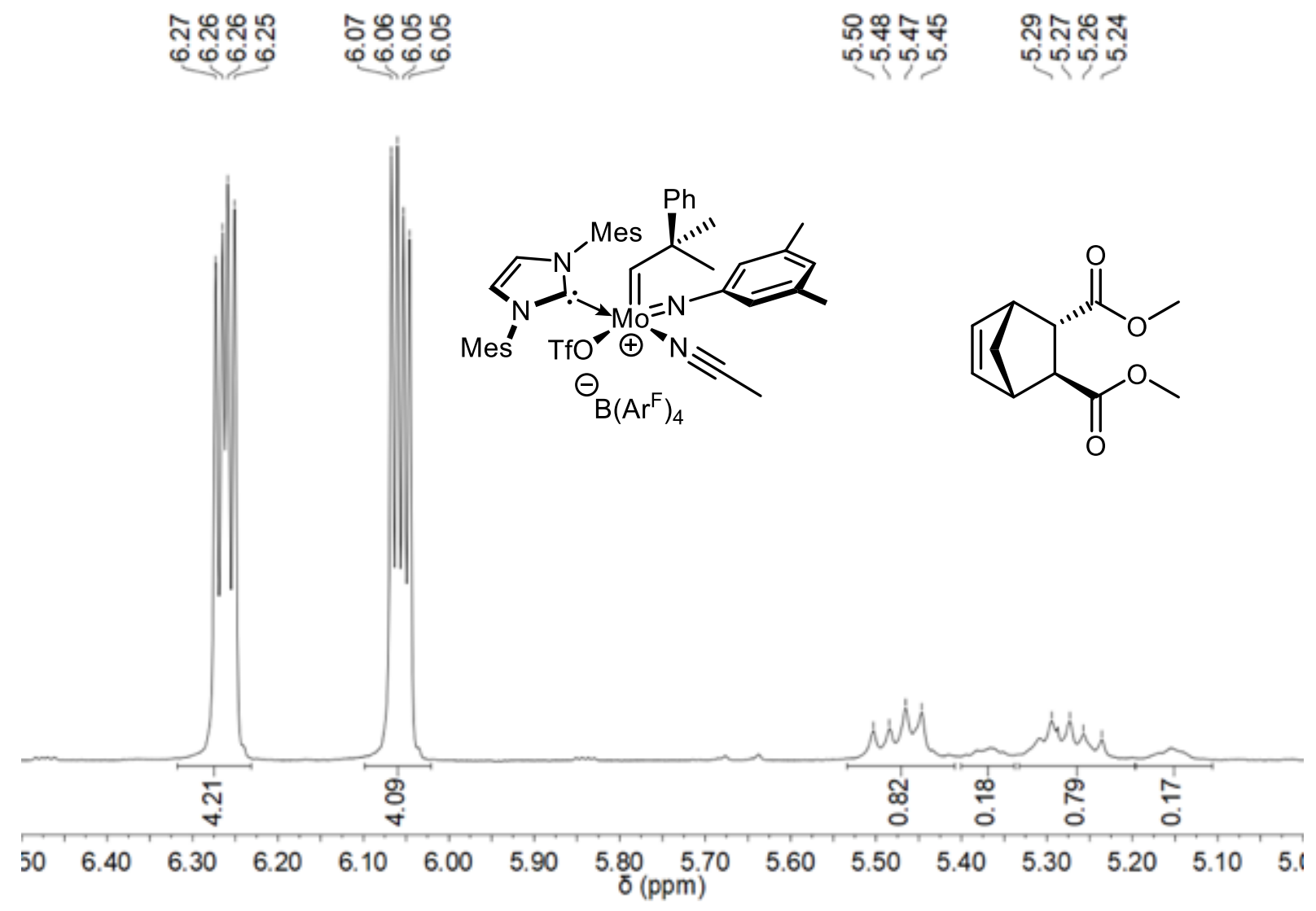

Figure S18: ${ }^{1} \mathrm{H}-\mathrm{NMR}$ spectrum $(400 \mathrm{MHz})$ of the polymerization of $\mathbf{M} 1$ using $\mathbf{I 1 7}$ in $\mathrm{CDCl}_{3}$.

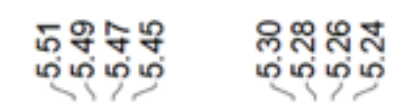<smiles></smiles><smiles>COC(=O)[C@H]1C2C=CC(C2)[C@H]1C(=O)OC</smiles>

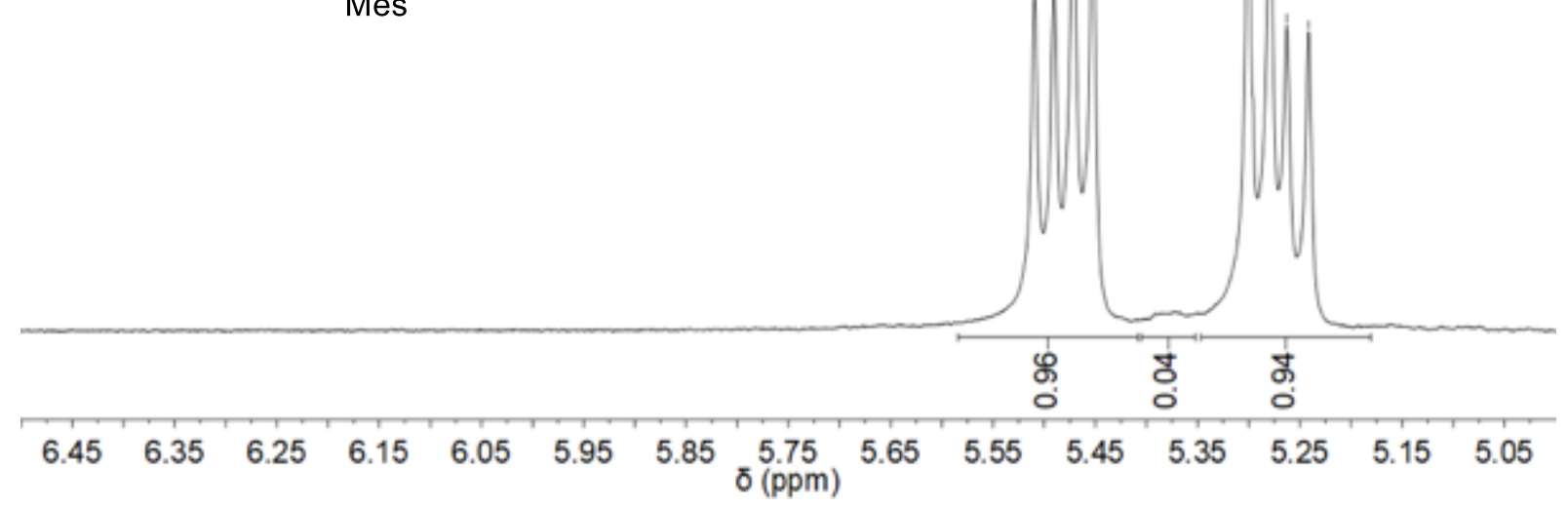

Figure S19: ${ }^{1} \mathrm{H}-\mathrm{NMR}$ spectrum $(400 \mathrm{MHz})$ of the polymerization of $\mathbf{M} 1$ using $\mathbf{I 1 8}$ in $\mathrm{CDCl}_{3}$. 


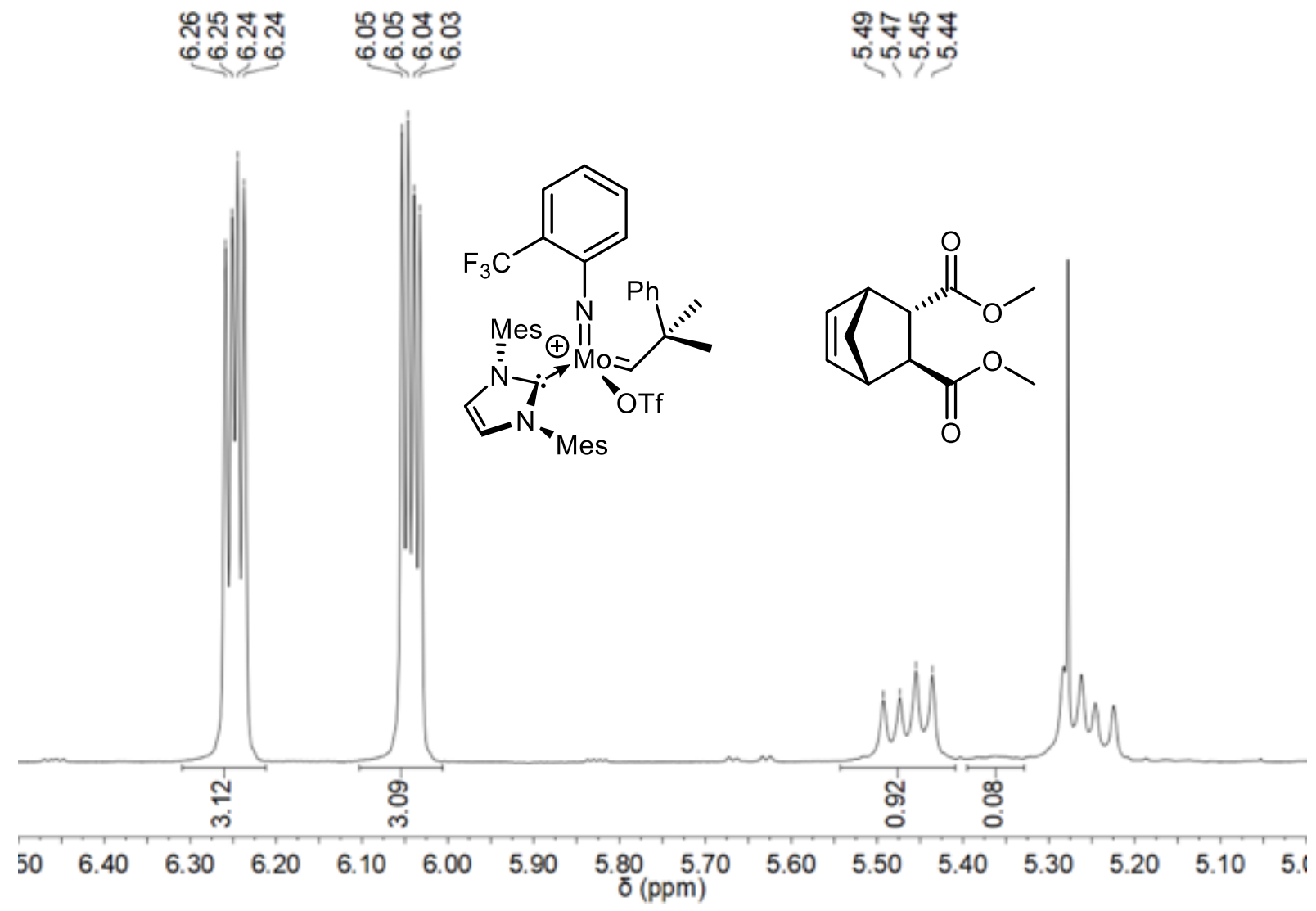

Figure S20: ${ }^{1} \mathrm{H}-\mathrm{NMR}$ spectrum $(400 \mathrm{MHz})$ of the polymerization of $\mathbf{M} 1$ using $\mathbf{I} 19$ in $\mathrm{CDCl}_{3}$.

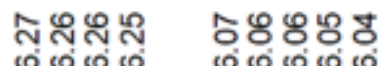

ம00

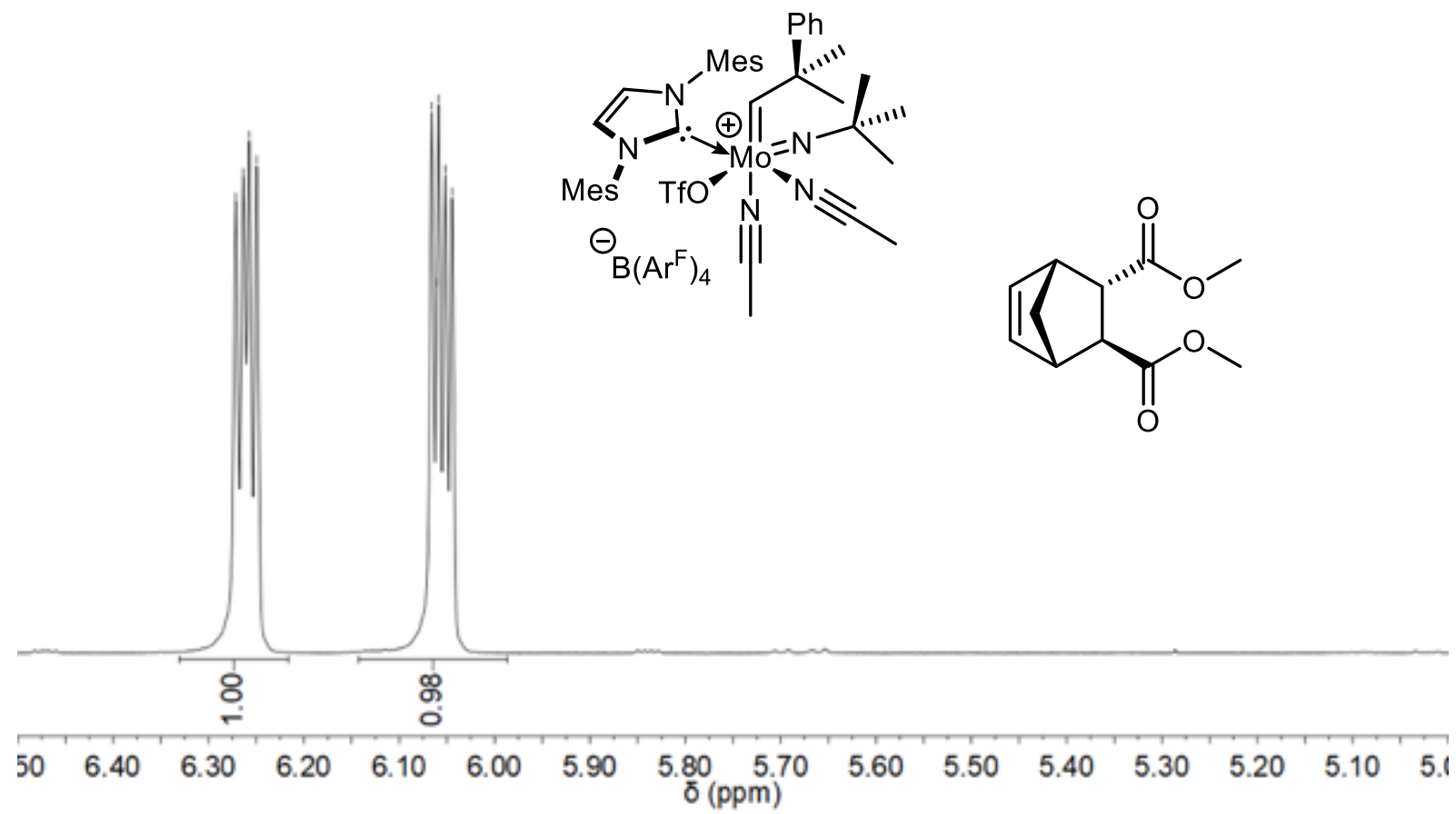

Figure S21: ${ }^{1} \mathrm{H}-\mathrm{NMR}$ spectrum $(400 \mathrm{MHz})$ of the polymerization of $\mathbf{M} 1$ using $\mathbf{I 2 0}$ in $\mathrm{CDCl}_{3}$. 


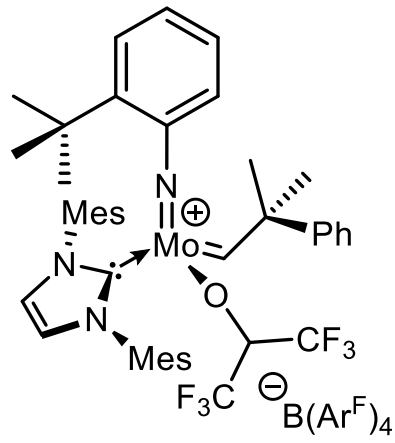<smiles>COC(=O)[C@H]1C2C=CC(C2)[C@H]1C(=O)OC</smiles>

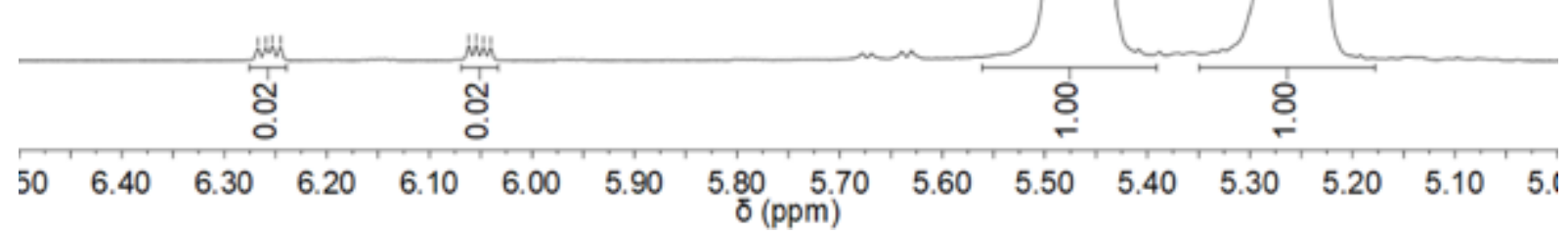

Figure S22: ${ }^{1} \mathrm{H}-\mathrm{NMR}$ spectrum $\left(400 \mathrm{MHz}\right.$ ) of the polymerization of $\mathbf{M} 1$ using $\mathbf{I 2 1}$ in $\mathrm{CDCl}_{3}$.

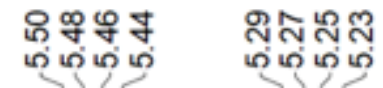

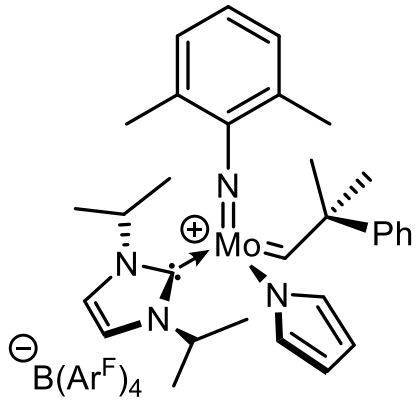<smiles>COC(=O)[C@H]1C2C=CC(C2)[C@H]1C(=O)OC</smiles>

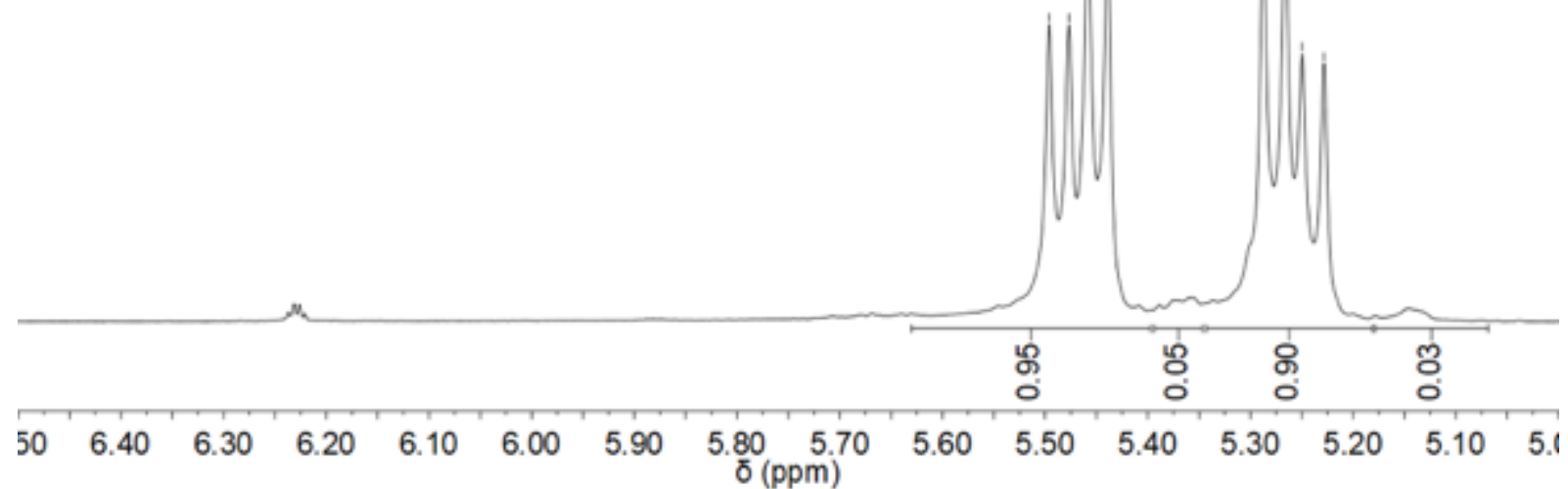

Figure S23: ${ }^{1} \mathrm{H}-\mathrm{NMR}$ spectrum $(400 \mathrm{MHz})$ of the polymerization of $\mathbf{M} 1$ using $\mathbf{1 2 2}$ in $\mathrm{CDCl}_{3}$. 


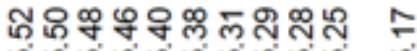

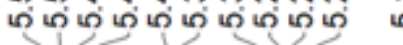

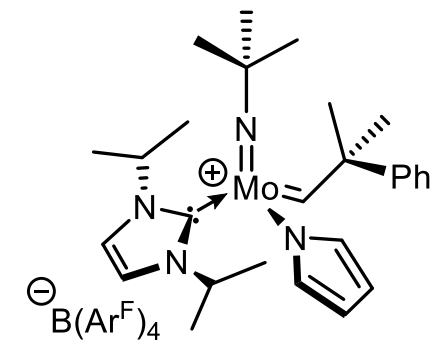<smiles>COC(=O)[C@H]1C2C=CC(C2)[C@H]1C(=O)OC</smiles>

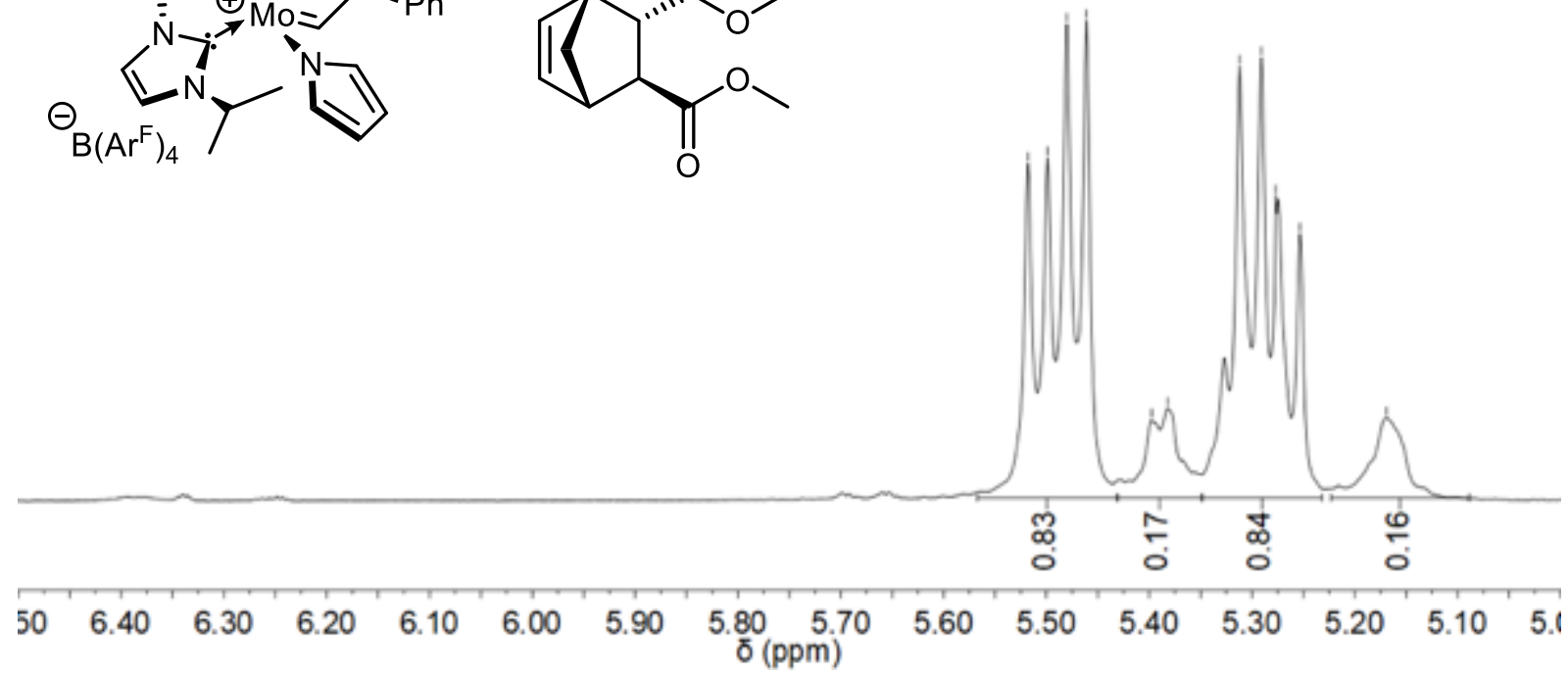

Figure S24: ${ }^{1} \mathrm{H}-\mathrm{NMR}$ spectrum $(400 \mathrm{MHz})$ of the polymerization of $\mathbf{M} 1$ using $\mathbf{I} 23$ in $\mathrm{CDCl}_{3}$.

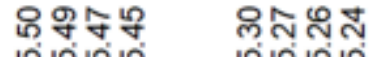

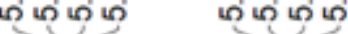
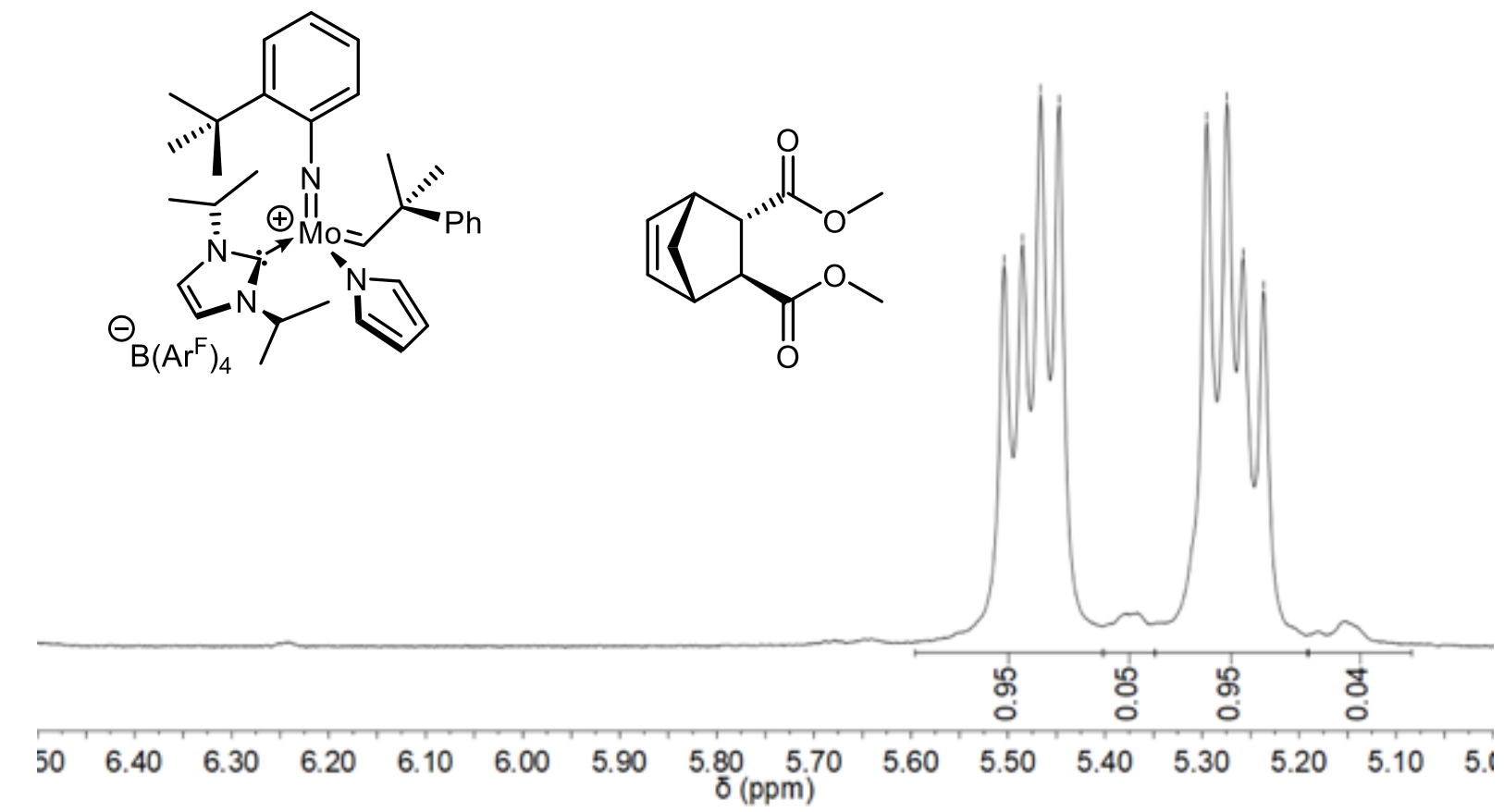

Figure S25: ${ }^{1} \mathrm{H}-\mathrm{NMR}$ spectrum $(400 \mathrm{MHz})$ of the polymerization of $\mathbf{M} 1$ using $\mathbf{I} 24$ in $\mathrm{CDCl}_{3}$. 

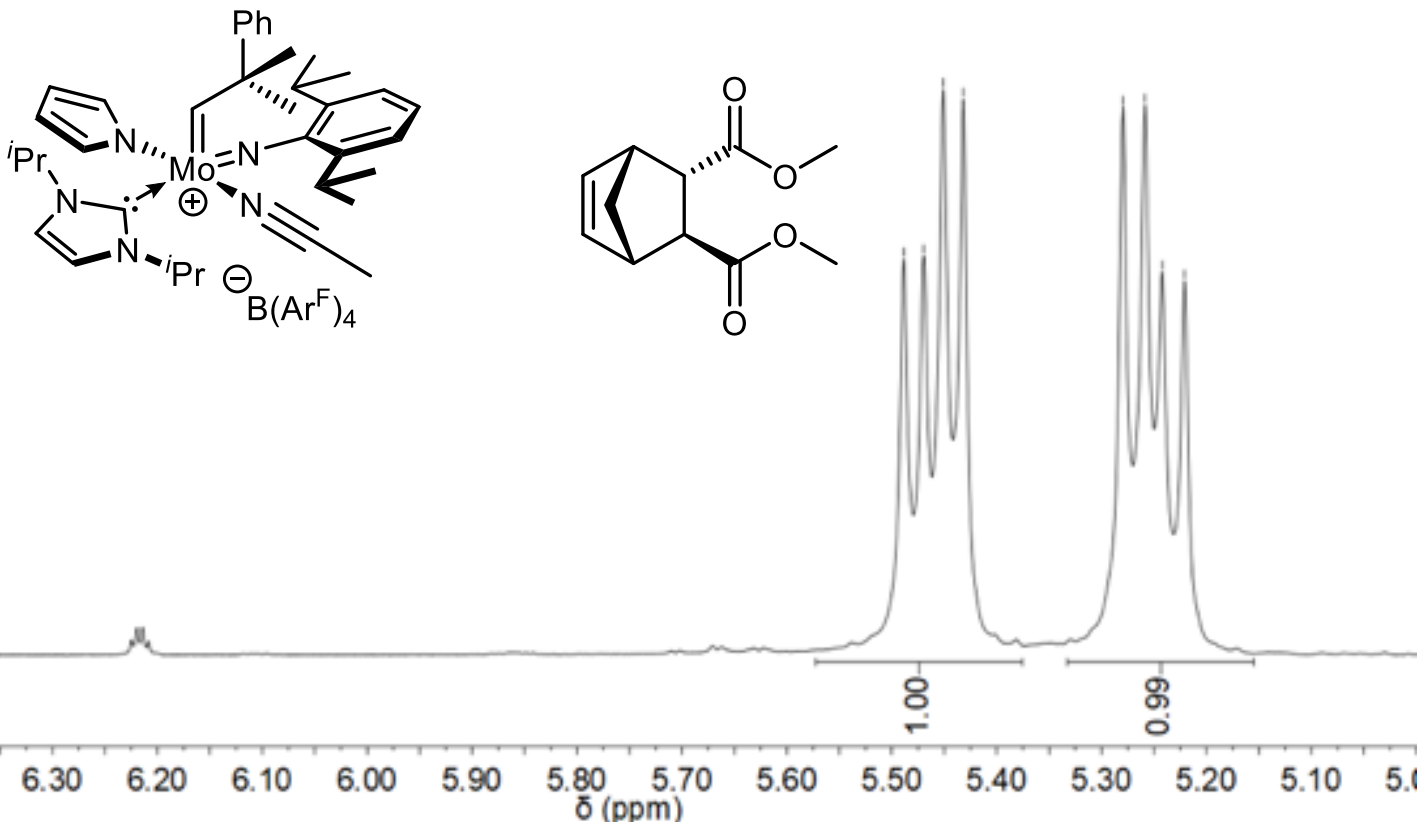

Figure S26: ${ }^{1} \mathrm{H}-\mathrm{NMR}$ spectrum $(400 \mathrm{MHz})$ of the polymerization of $\mathbf{M} 1$ using $\mathbf{I 2 5}$ in $\mathrm{CDCl}_{3}$.

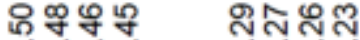

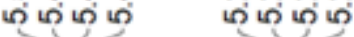

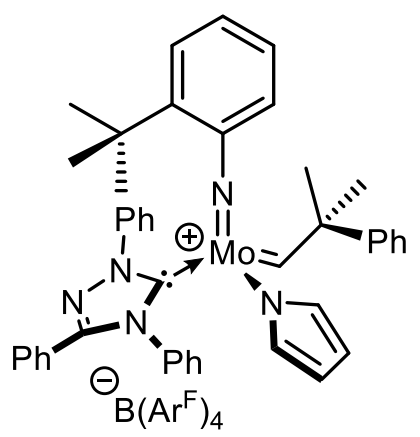<smiles>COC(=O)[C@H]1[C@@H]2C=C[C@H](C2)[C@H]1C(=O)OC</smiles><smiles>C1#CCCC1</smiles>

Figure S27: ${ }^{1} \mathrm{H}-\mathrm{NMR}$ spectrum $(400 \mathrm{MHz})$ of the polymerization of $\mathbf{M} 1$ using $\mathbf{I 2 6}$ in $\mathrm{CDCl}_{3}$. 

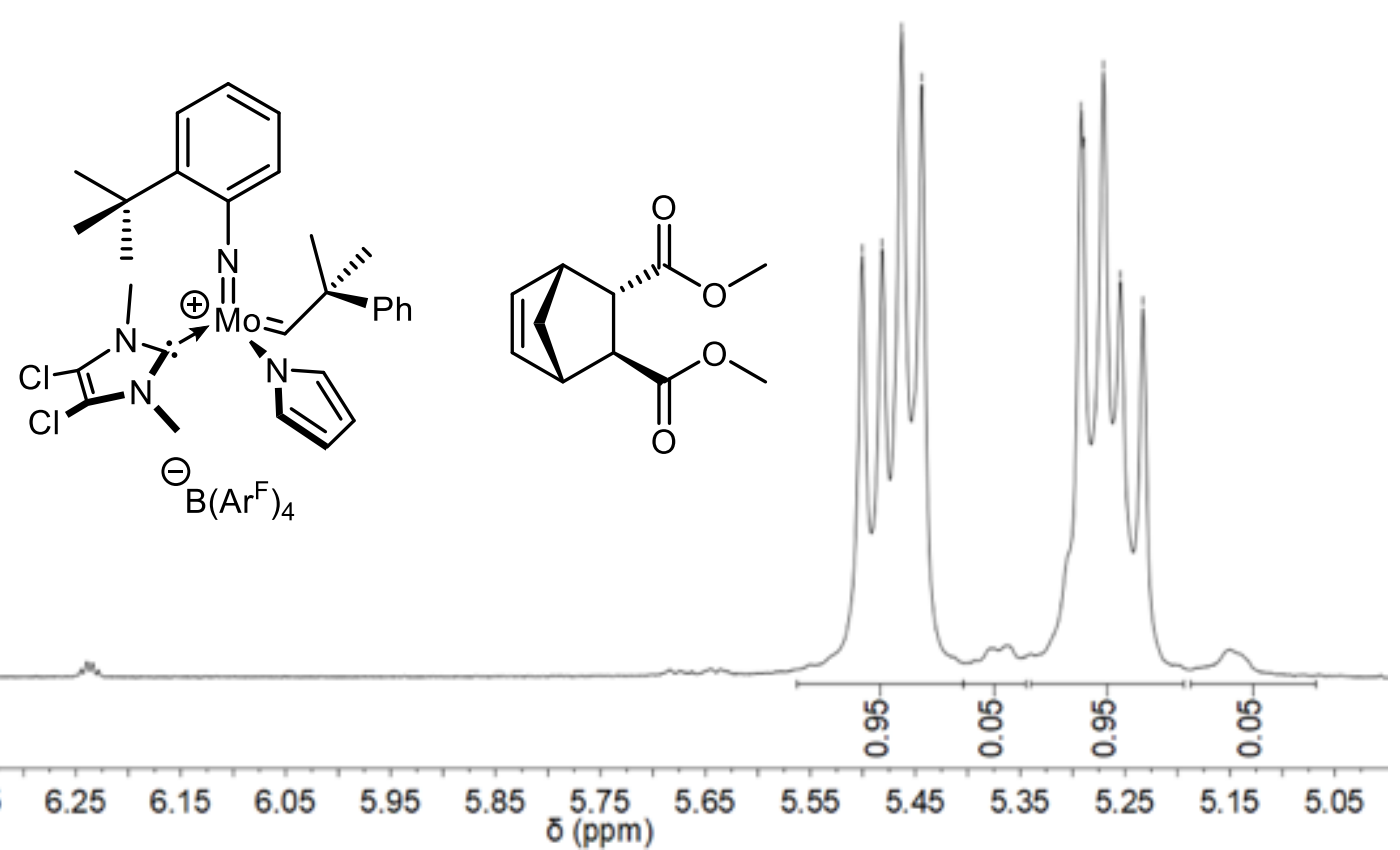

Figure S28: ${ }^{1} \mathrm{H}-\mathrm{NMR}$ spectrum $(400 \mathrm{MHz})$ of the polymerization of $\mathbf{M} 1$ using $\mathbf{I 2 7}$ in $\mathrm{CDCl}_{3}$.

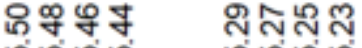

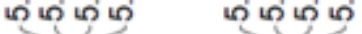

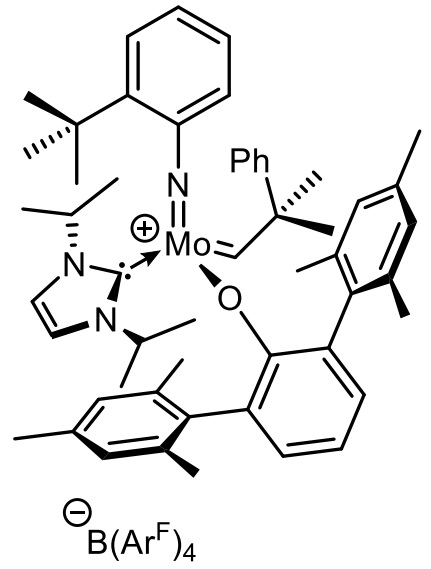<smiles>COC(=O)[C@H]1C2C=CC(C2)[C@H]1C(=O)OC</smiles>

$\Theta_{\mathrm{B}\left(\mathrm{Ar} \mathrm{F}^{\mathrm{F}}\right)_{4}}$

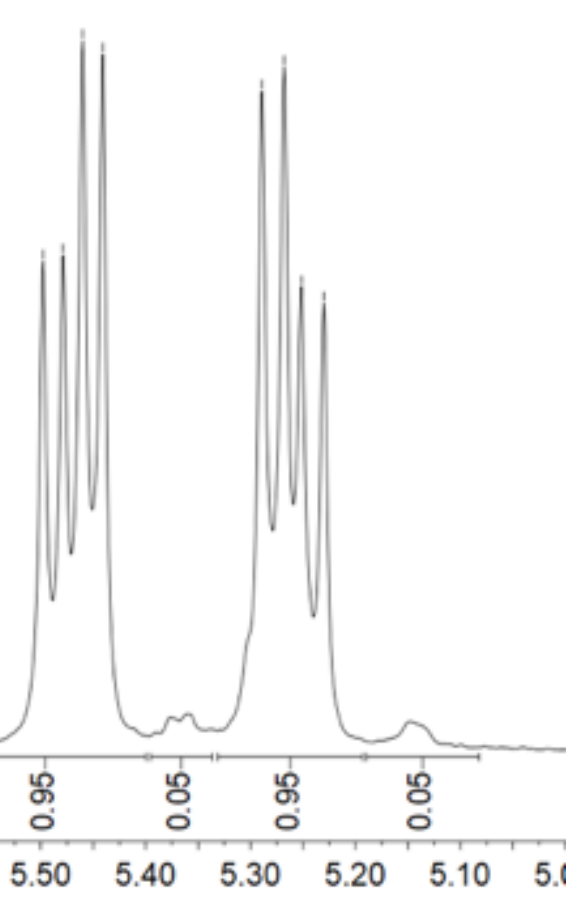

Figure S29: ${ }^{1} \mathrm{H}-\mathrm{NMR}$ spectrum $(400 \mathrm{MHz})$ of the polymerization of $\mathbf{M} 1 \mathrm{using} \mathbf{I 2 8}$ in $\mathrm{CDCl}_{3}$. 

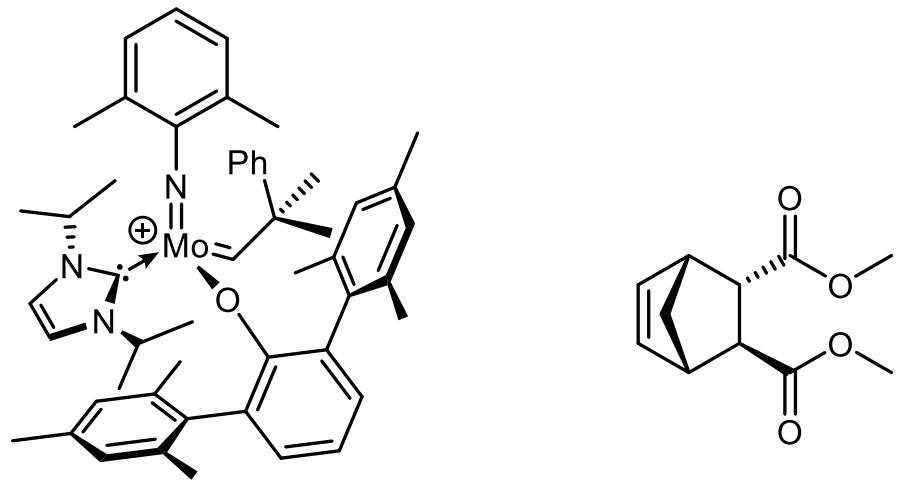

$\Theta_{\mathrm{B}\left(\mathrm{Ar}^{\mathrm{F}}\right)_{4}}$

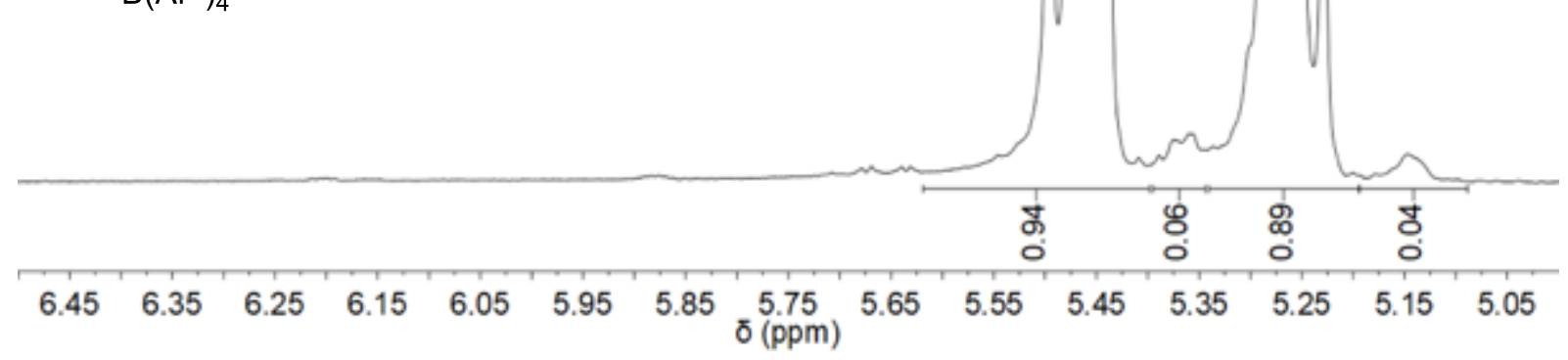

Figure S30: ${ }^{1} \mathrm{H}-\mathrm{NMR}$ spectrum (400 MHz) of the polymerization of $\mathbf{M} 1$ using $\mathbf{I 2 9}$ in $\mathrm{CDCl}_{3}$.

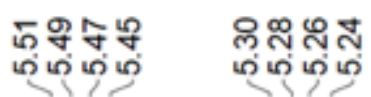

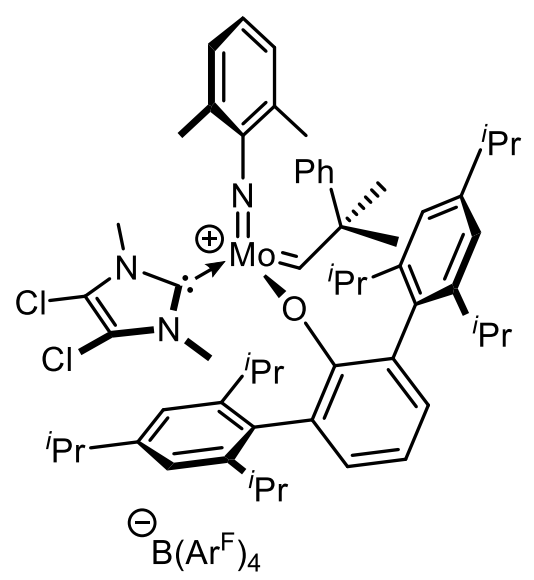<smiles>COC(=O)[C@H]1C2C=CC(C2)[C@H]1C(=O)OC</smiles>

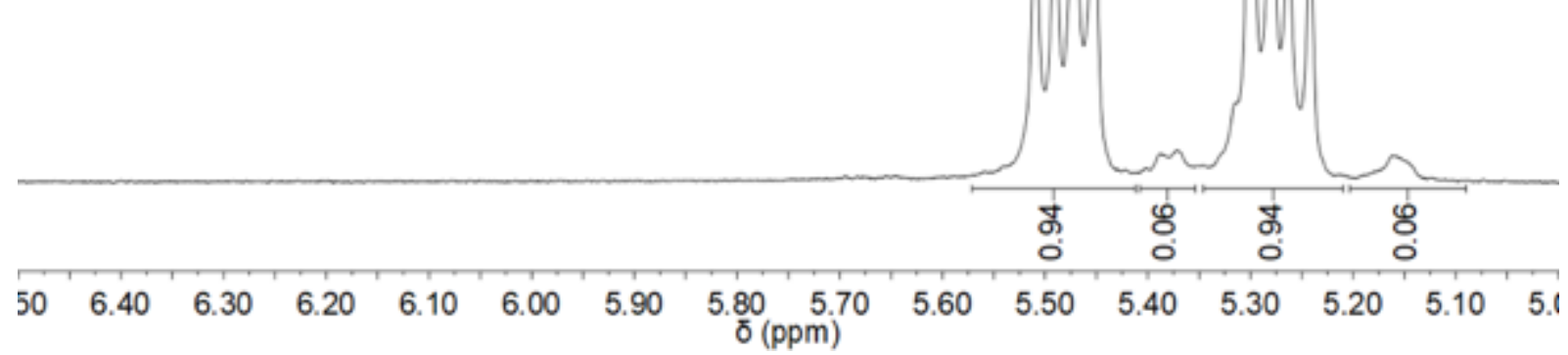

Figure S31: ${ }^{1} \mathrm{H}-\mathrm{NMR}$ spectrum $(400 \mathrm{MHz})$ of the polymerization of $\mathbf{M} 1$ using $\mathbf{I} 30$ in $\mathrm{CDCl}_{3}$. 


\section{Complexes}

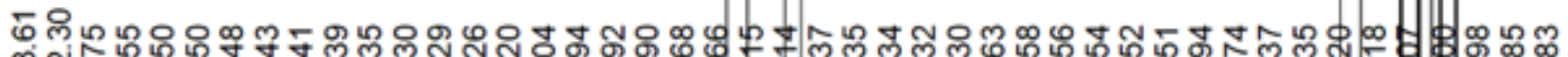

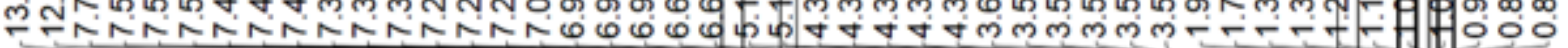

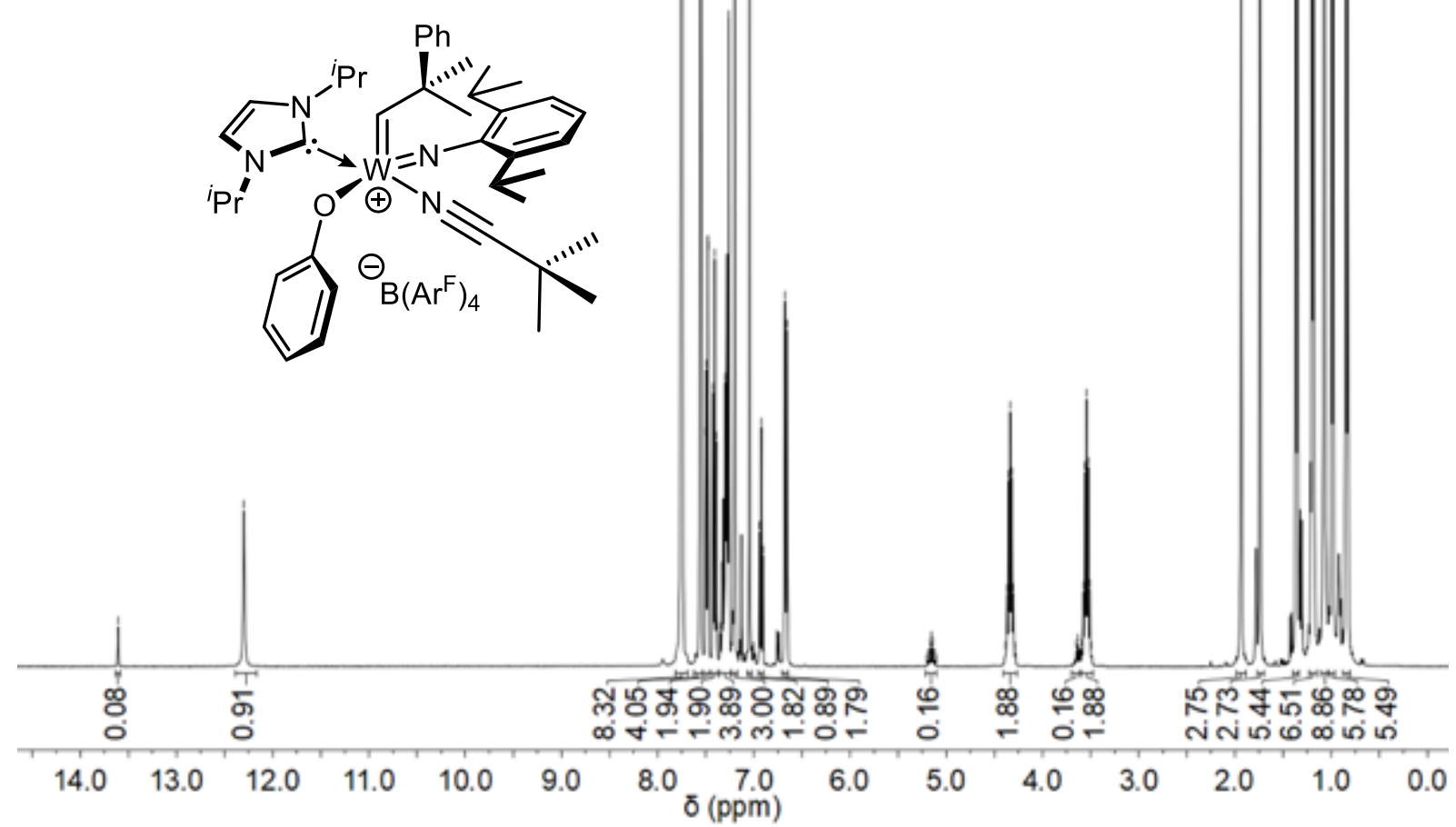

Figure S32: ${ }^{1} \mathrm{H}-\mathrm{NMR}$ spectrum $(400 \mathrm{MHz})$ of initiator 14 in $\mathrm{CDCl}_{3}$.

苞

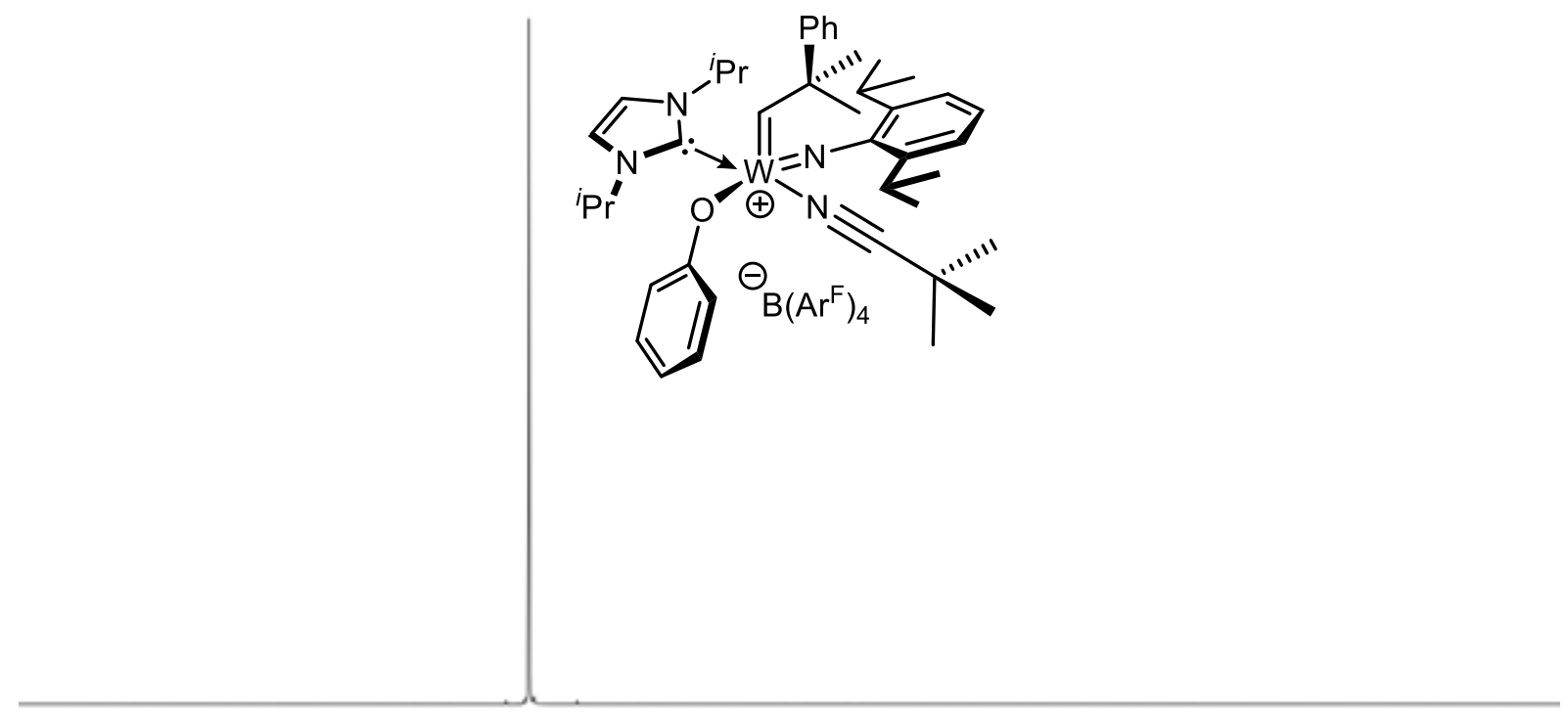

$\begin{array}{lllllllllllllll}-58 & -59 & -60 & -61 & -62 & -63 & -64 & -65 & -66 & -67 & -68 & -69 & -70 & -71 & -72\end{array}$

Figure S33: ${ }^{19} \mathrm{~F}-\mathrm{NMR}$ spectrum $(376 \mathrm{MHz})$ of initiator $\mathbf{1 4}$ in $\mathrm{CDCl}_{3}$. 


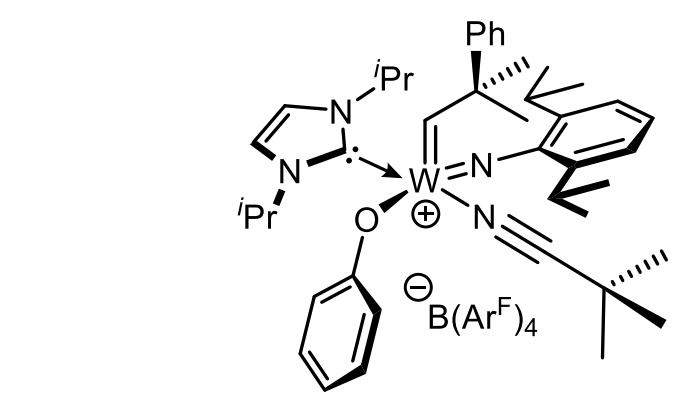

$\begin{array}{llllllllllllll}290 & 270 & 250 & 230 & 210 & 190 & \begin{array}{r}170 \\ \delta(\mathrm{ppm})\end{array} & 130 & 110 & 90 & 70 & 50 & 30 & 10\end{array}$

Figure S34: ${ }^{13} \mathrm{C}-\mathrm{NMR}$ spectrum $(101 \mathrm{MHz})$ of initiator $\mathrm{I4}$ in $\mathrm{CDCl}_{3}$.

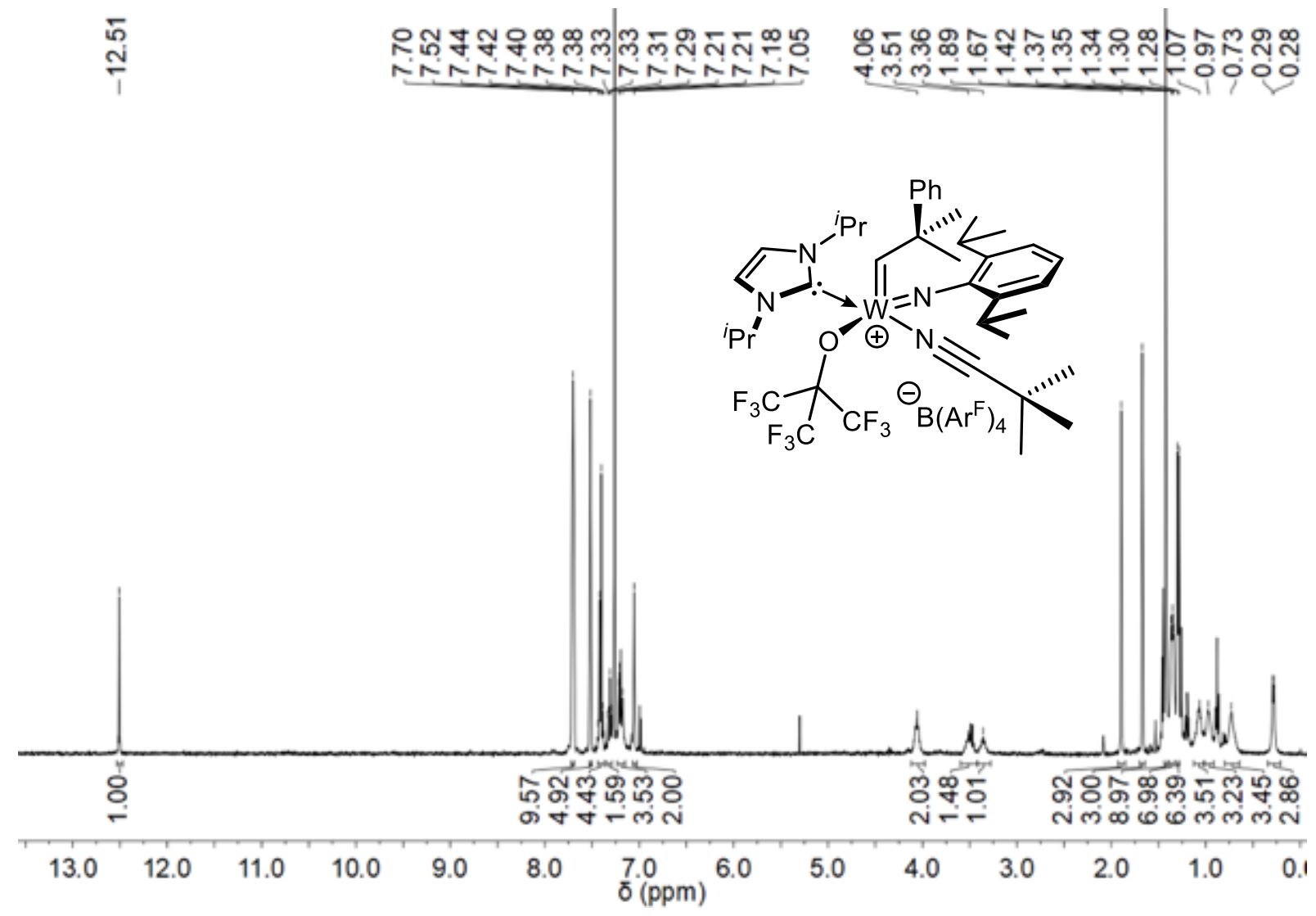

Figure S35: ${ }^{1} \mathrm{H}-\mathrm{NMR}$ spectrum $(400 \mathrm{MHz})$ of initiator $\mathbf{I 5}$ in $\mathrm{CDCl}_{3}$. 


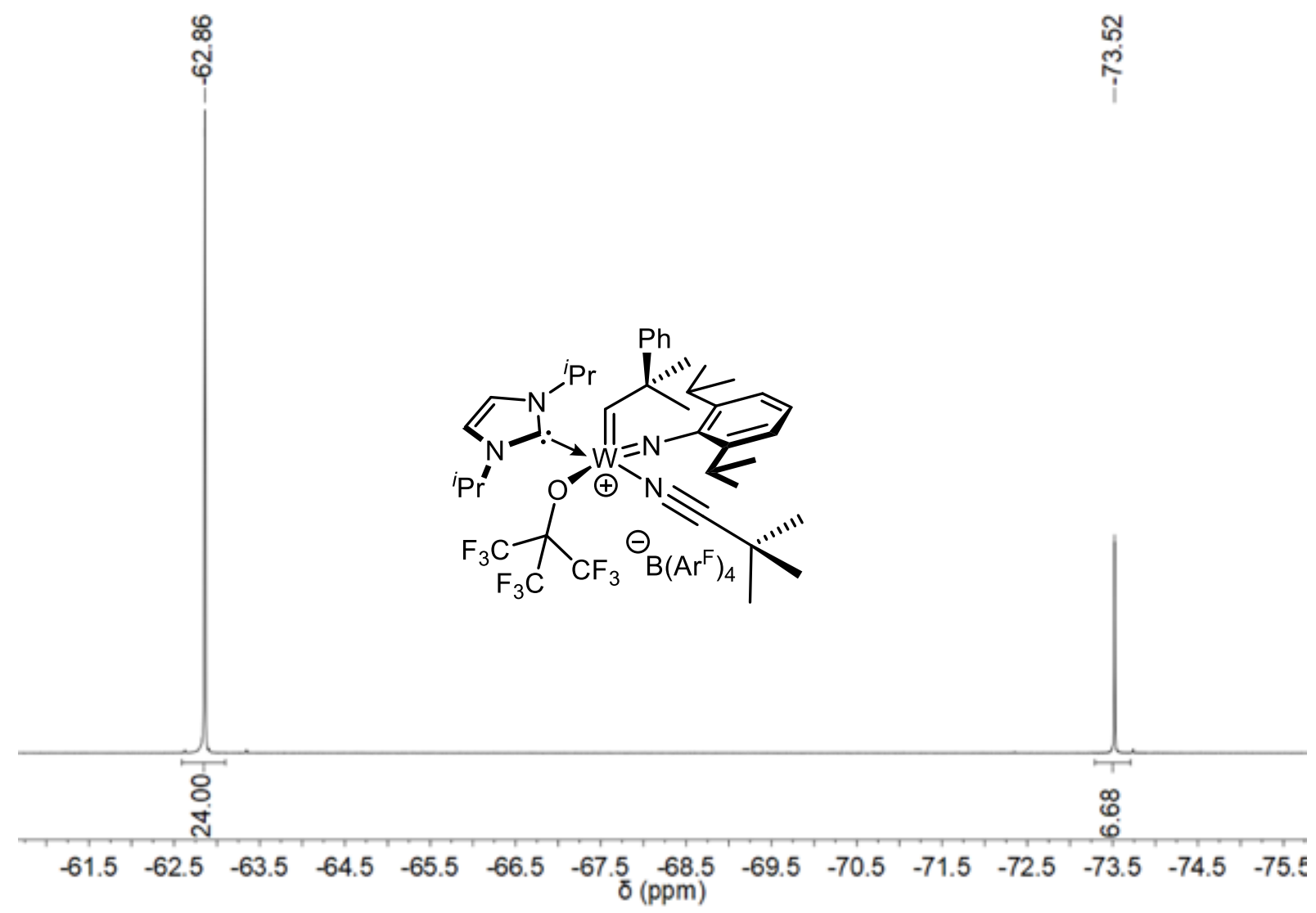

Figure S36: ${ }^{19} \mathrm{~F}-\mathrm{NMR}$ spectrum $(376 \mathrm{MHz})$ of initiator $\mathrm{I5}$ in $\mathrm{CDCl}_{3}$.
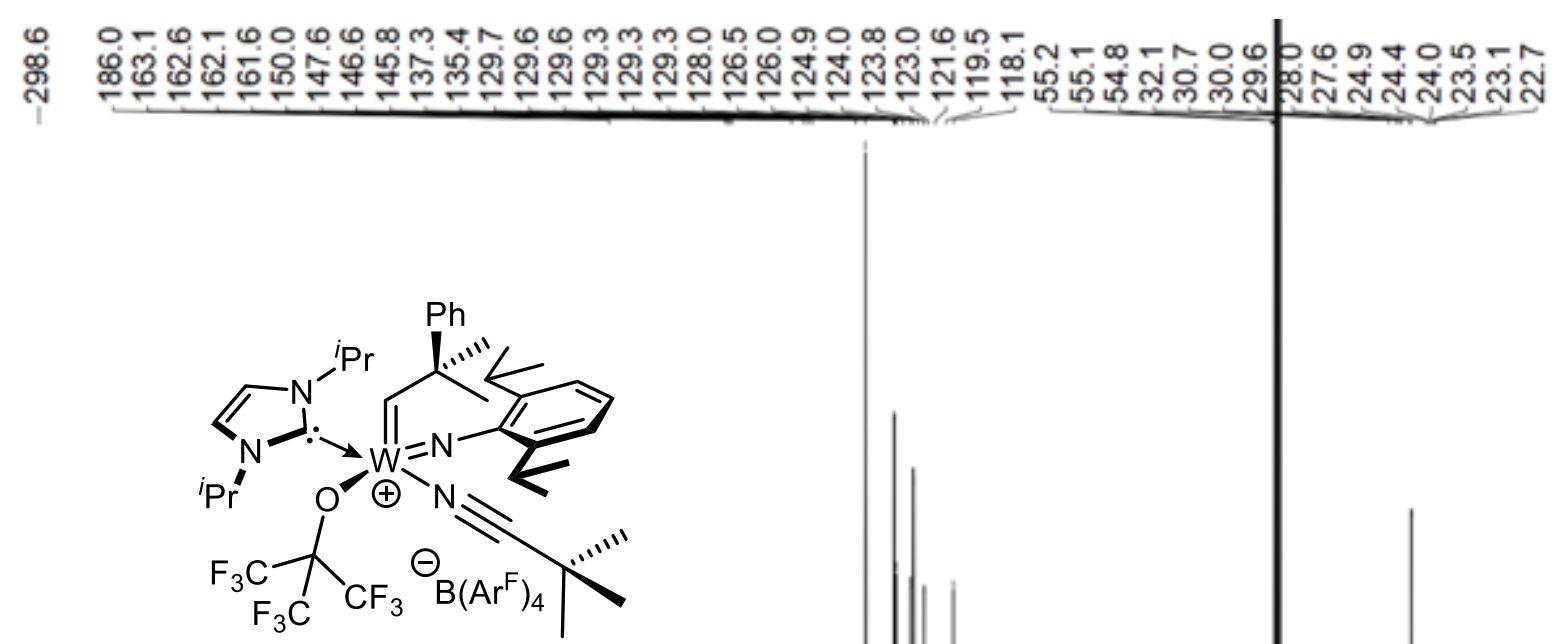

$\begin{array}{llllllllllllllll}300 & 280 & 260 & 240 & 220 & 200 & 180 & \begin{array}{l}160 \\ \delta(\mathrm{ppm})\end{array} & 140 & 120 & 100 & 80 & 60 & 40 & 20 & \mathrm{C}\end{array}$

Figure S37: ${ }^{13} \mathrm{C}-\mathrm{NMR}$ spectrum $(101 \mathrm{MHz})$ of initiator 15 in $\mathrm{CDCl}_{3}$. 


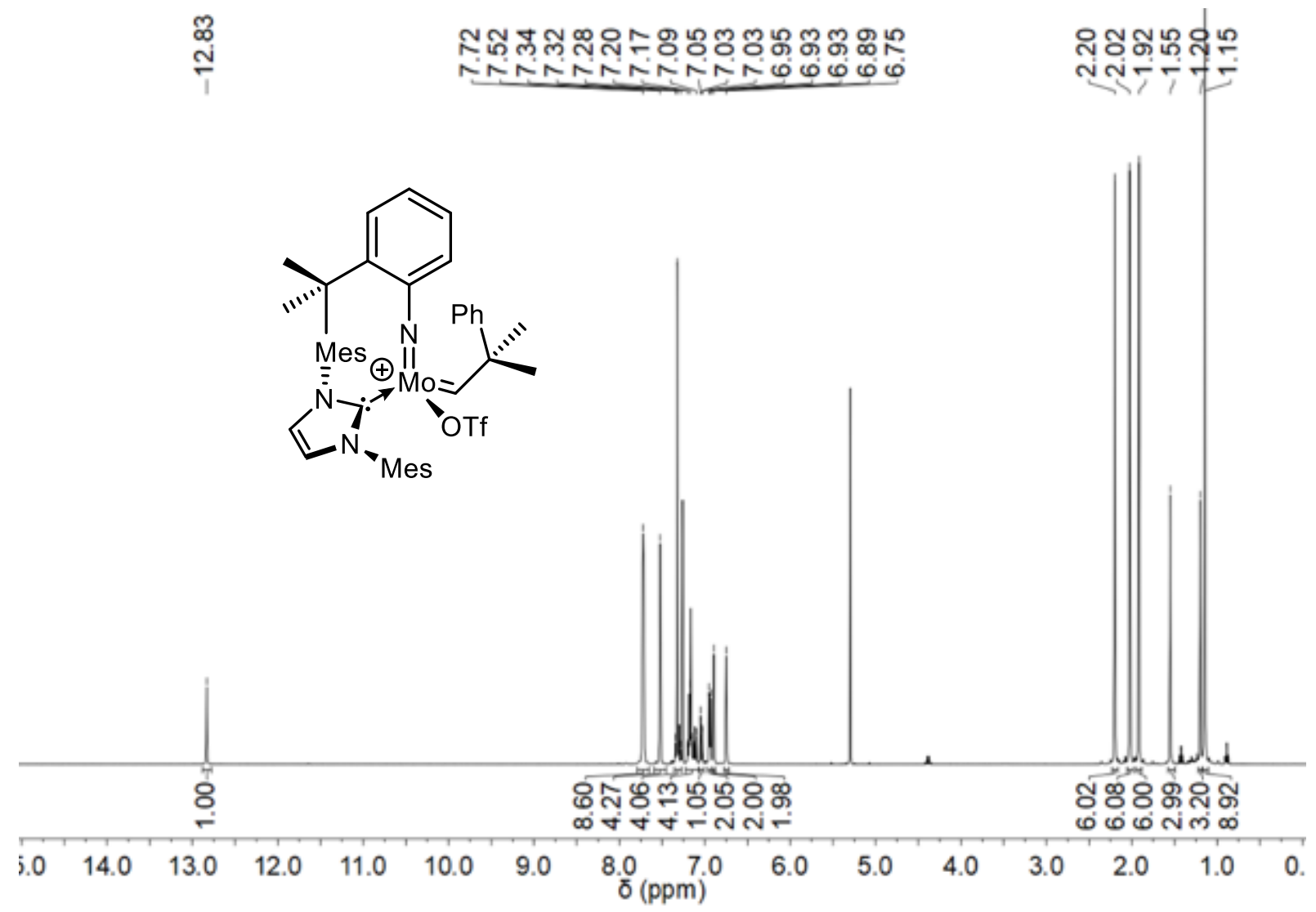

Figure S38: ${ }^{1} \mathrm{H}-\mathrm{NMR}$ spectrum $(400 \mathrm{MHz})$ of initiator I15 in $\mathrm{CDCl}_{3}$.

ㅇํํ

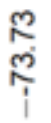

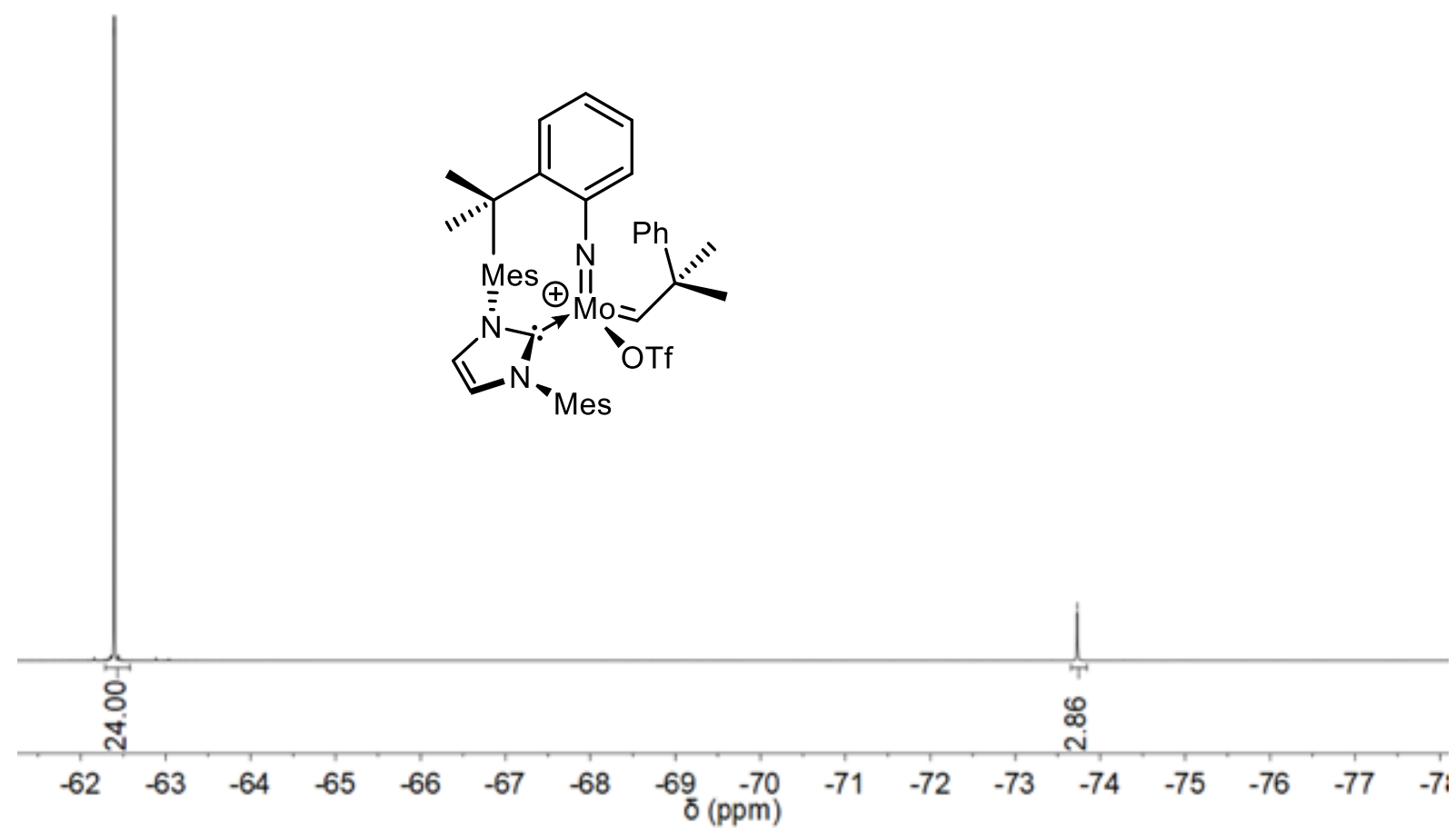

Figure S39: ${ }^{19} \mathrm{~F}-\mathrm{NMR}$ spectrum $(376 \mathrm{MHz})$ of initiator I15 in $\mathrm{CDCl}_{3}$. 


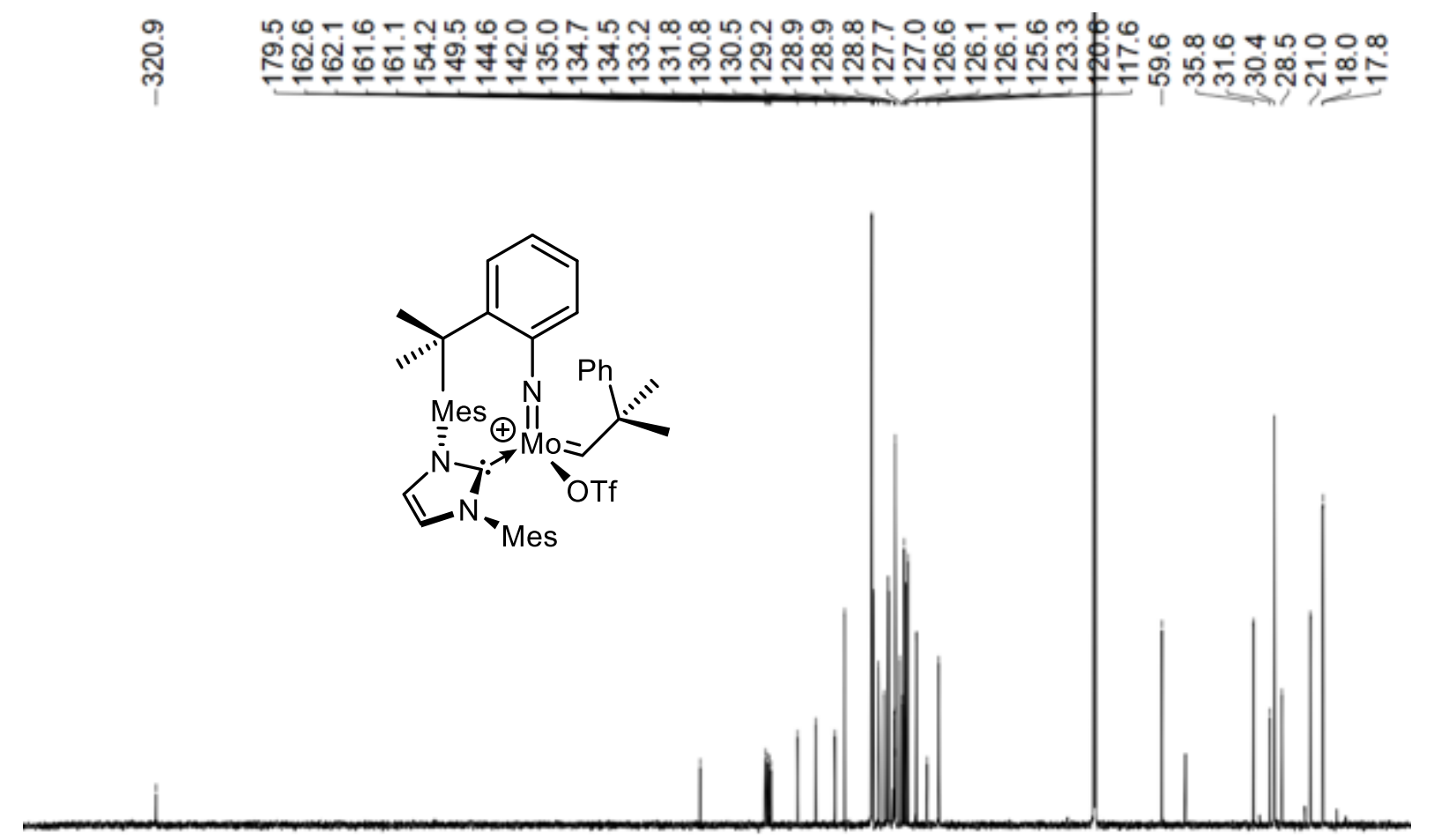

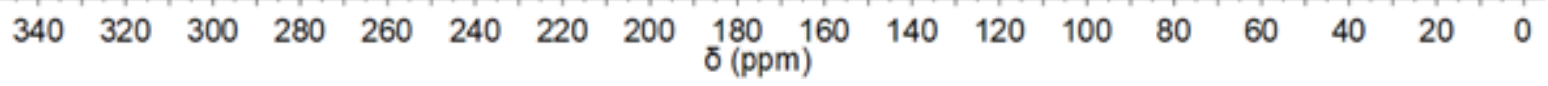

Figure S40: ${ }^{13} \mathrm{C}-\mathrm{NMR}$ spectrum $(101 \mathrm{MHz})$ of initiator $\mathrm{I15}$ in $\mathrm{CDCl}_{3}$.

品

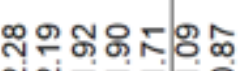

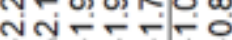

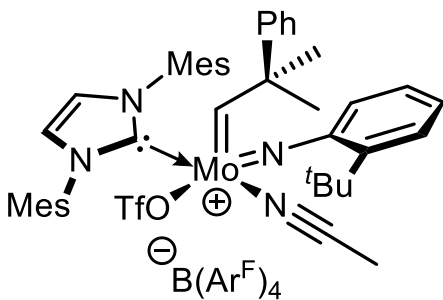

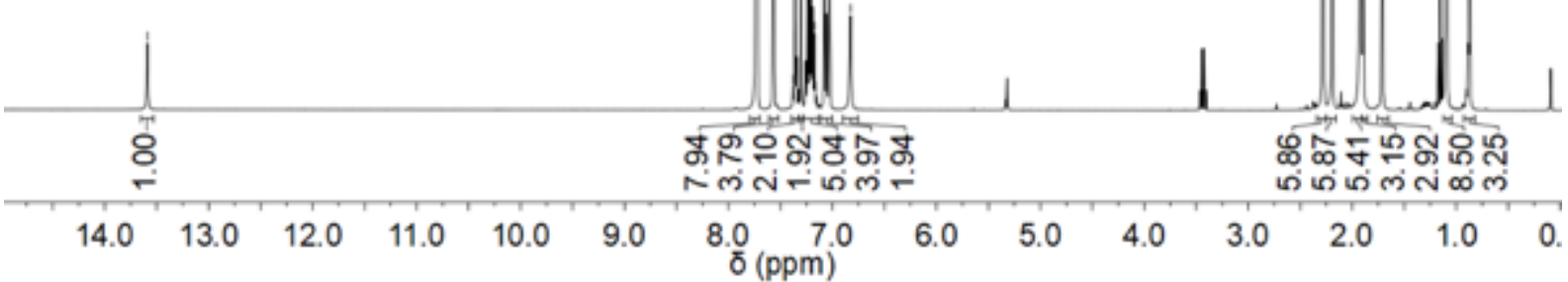

Figure S41: ${ }^{1} \mathrm{H}-\mathrm{NMR}$ spectrum $(400 \mathrm{MHz})$ of initiator I15-MeCN in $\mathrm{CD}_{2} \mathrm{Cl}_{2}$. 


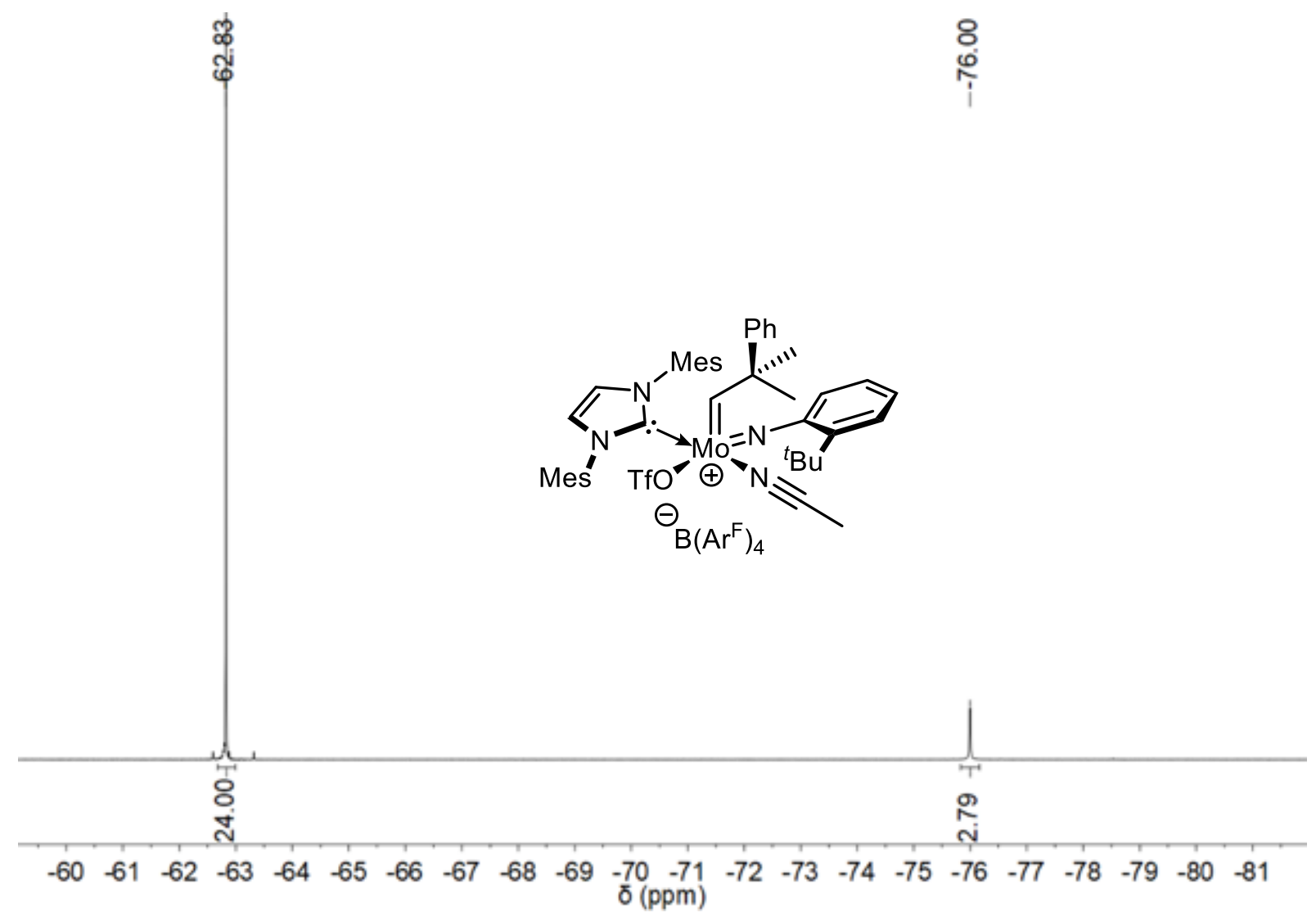

Figure S42: ${ }^{19} \mathrm{~F}-\mathrm{NMR}$ spectrum (376 MHz) of initiator I15-MeCN in $\mathrm{CD}_{2} \mathrm{Cl}_{2}$.

సั กิ

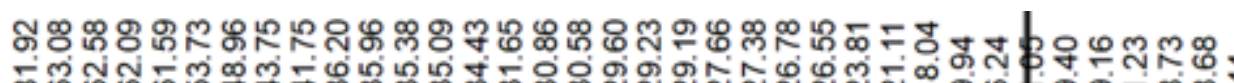

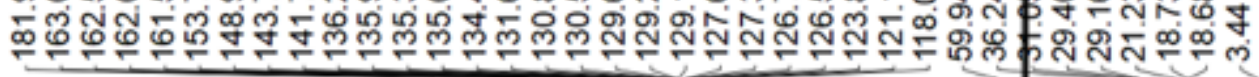

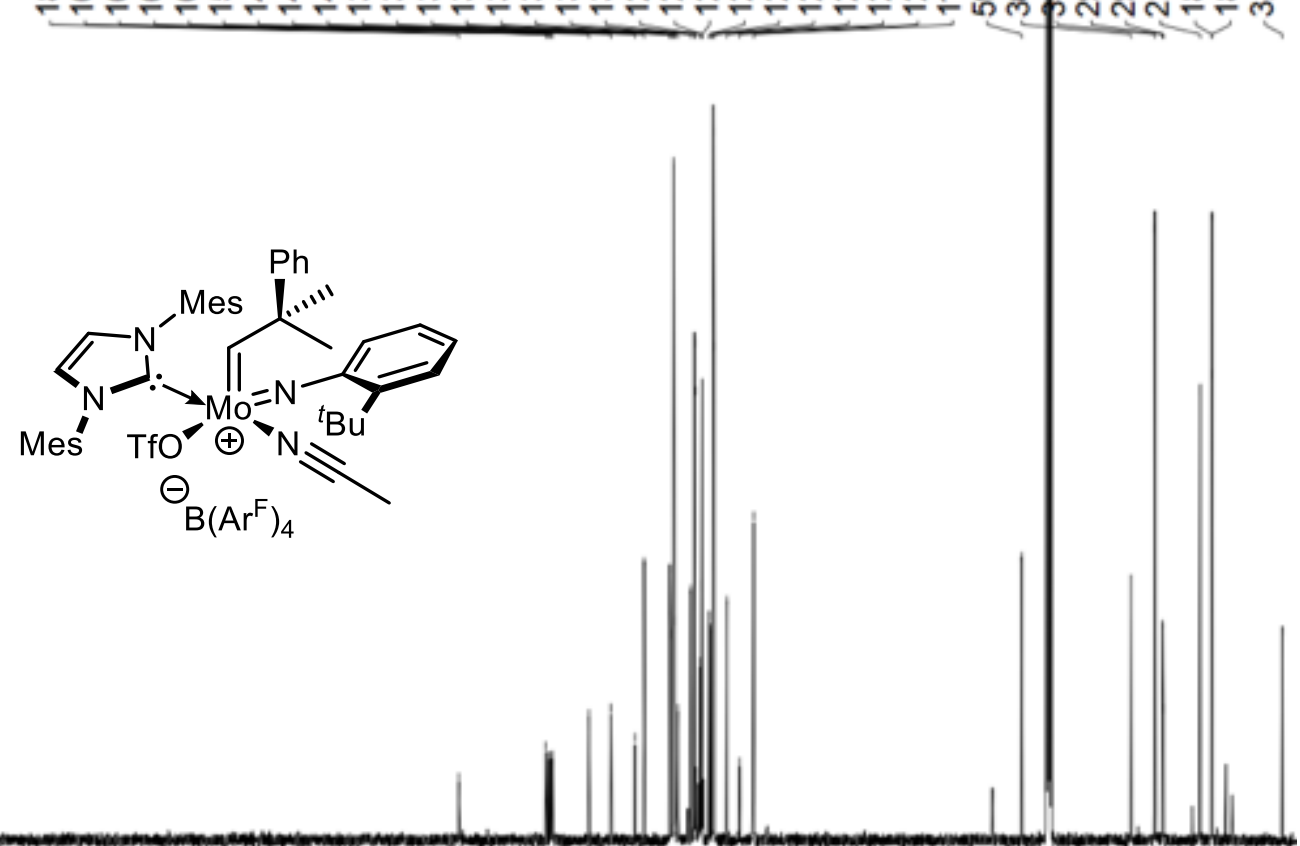

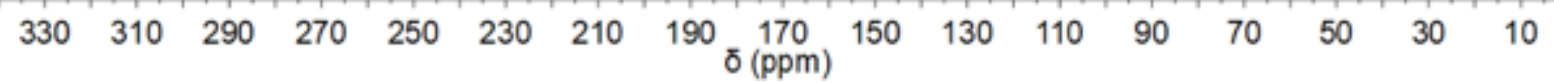

Figure S43: ${ }^{13} \mathrm{C}-\mathrm{NMR}$ spectrum (101 MHz) of initiator I15-MeCN in $\mathrm{CD}_{2} \mathrm{Cl}_{2}$. 


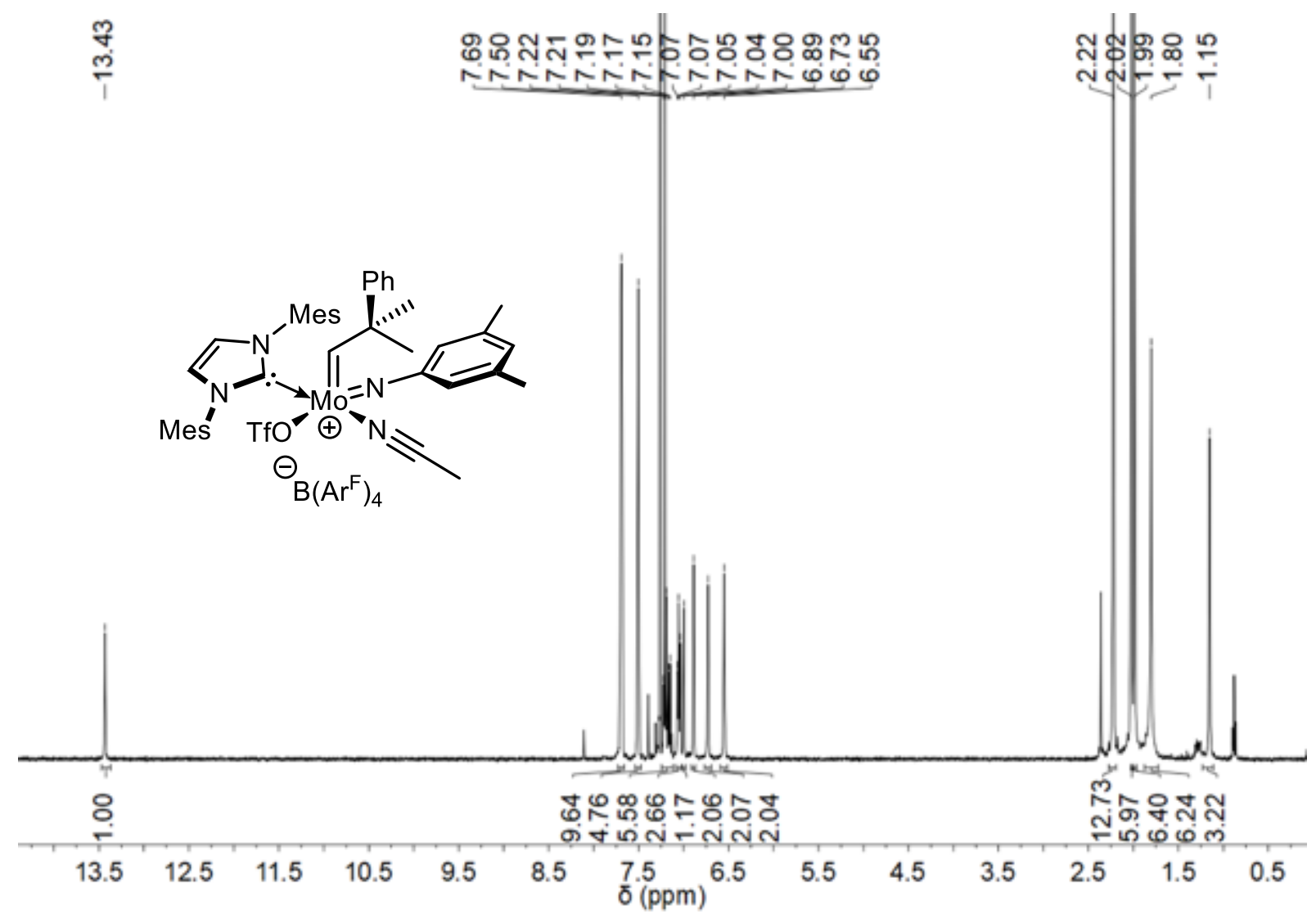

Figure S44: ${ }^{1} \mathrm{H}-\mathrm{NMR}$ spectrum $(400 \mathrm{MHz})$ of initiator $\mathrm{I17}$ in $\mathrm{CDCl}_{3}$.

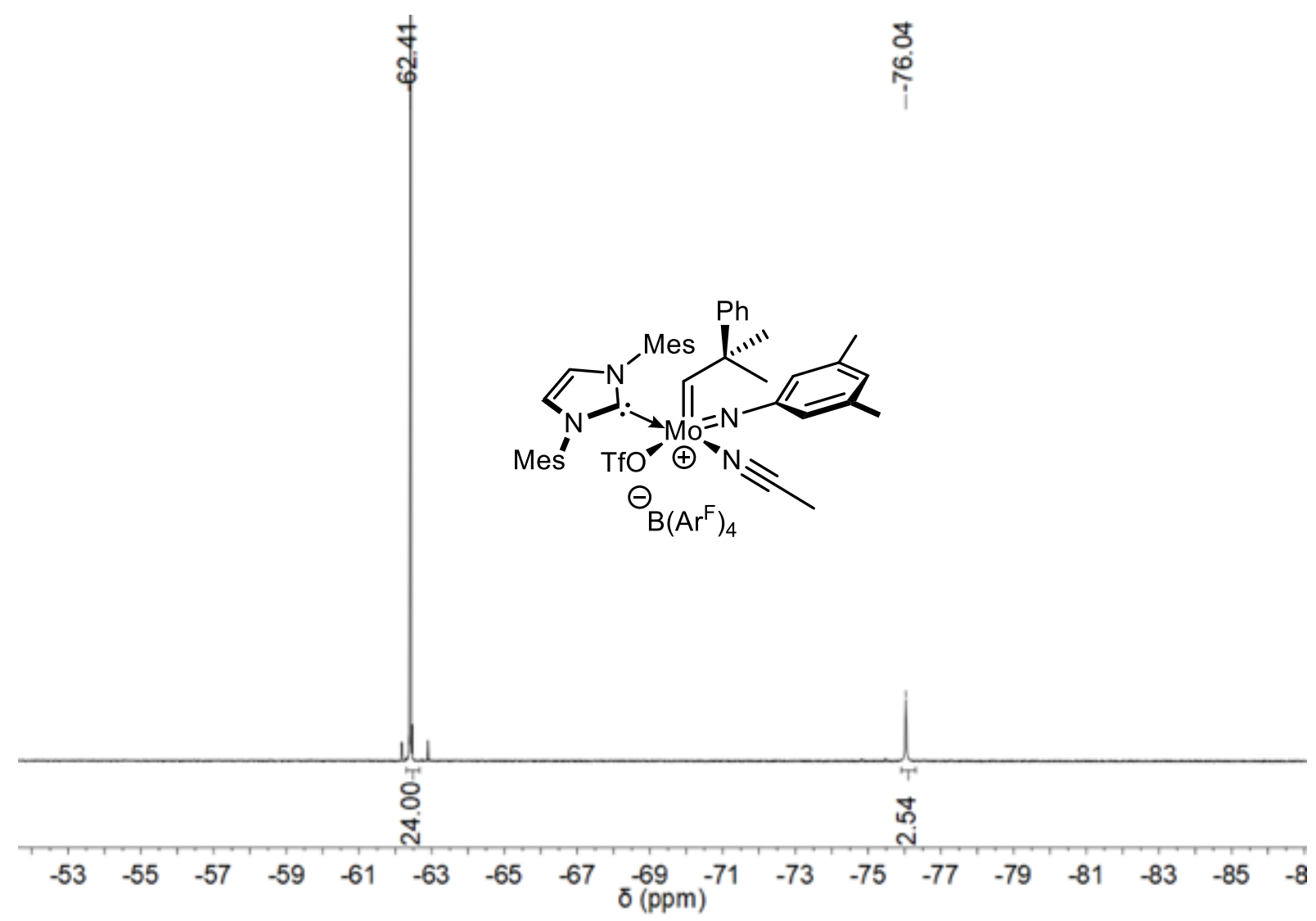

Figure S45: ${ }^{19} \mathrm{~F}-\mathrm{NMR}$ spectrum $(376 \mathrm{MHz})$ of initiator $\mathrm{I17}$ in $\mathrm{CDCl}_{3}$. 


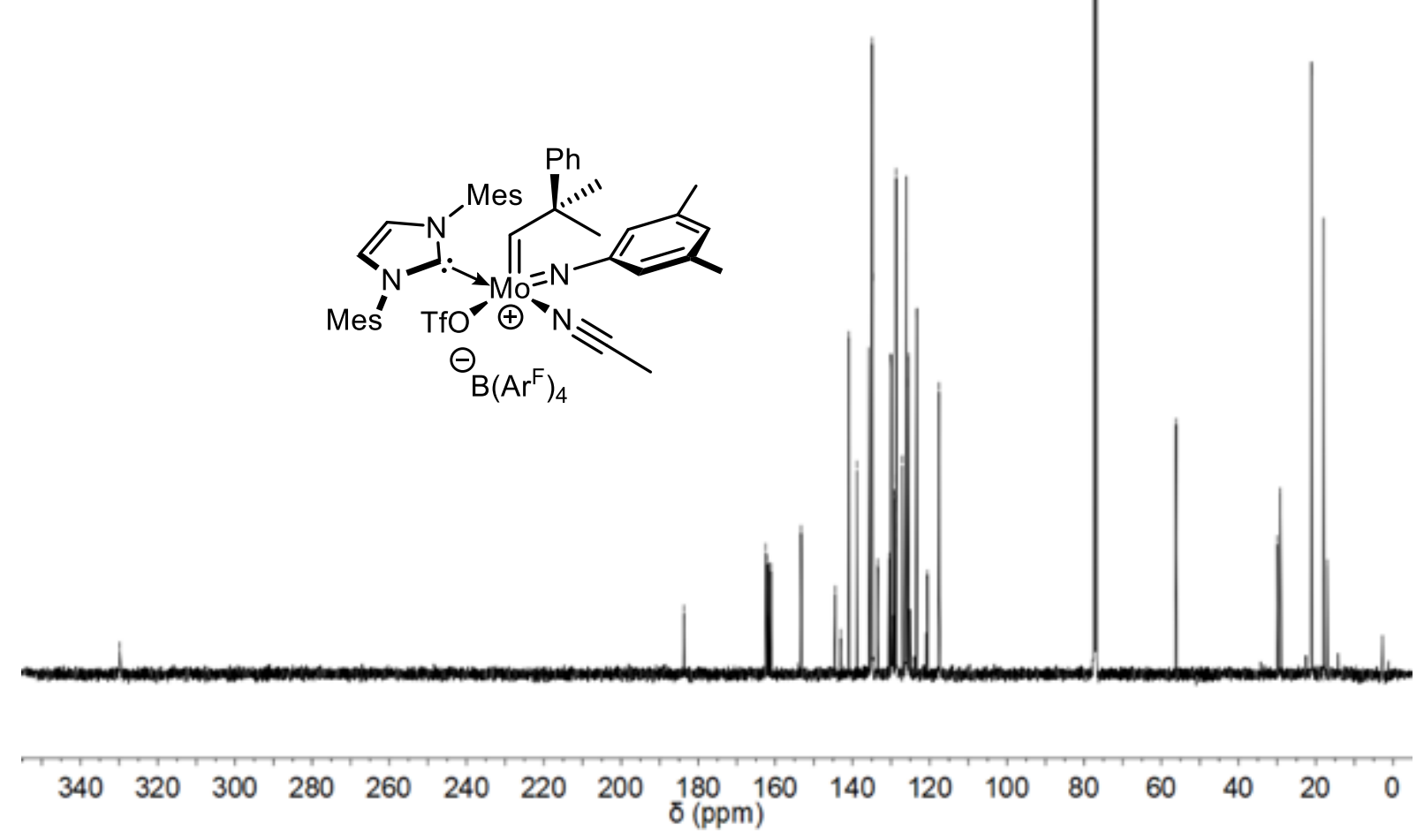

Figure S46: ${ }^{13} \mathrm{C}-\mathrm{NMR}$ spectrum $(101 \mathrm{MHz})$ of initiator $\mathbf{I 1 7}$ in $\mathrm{CDCl}_{3}$.
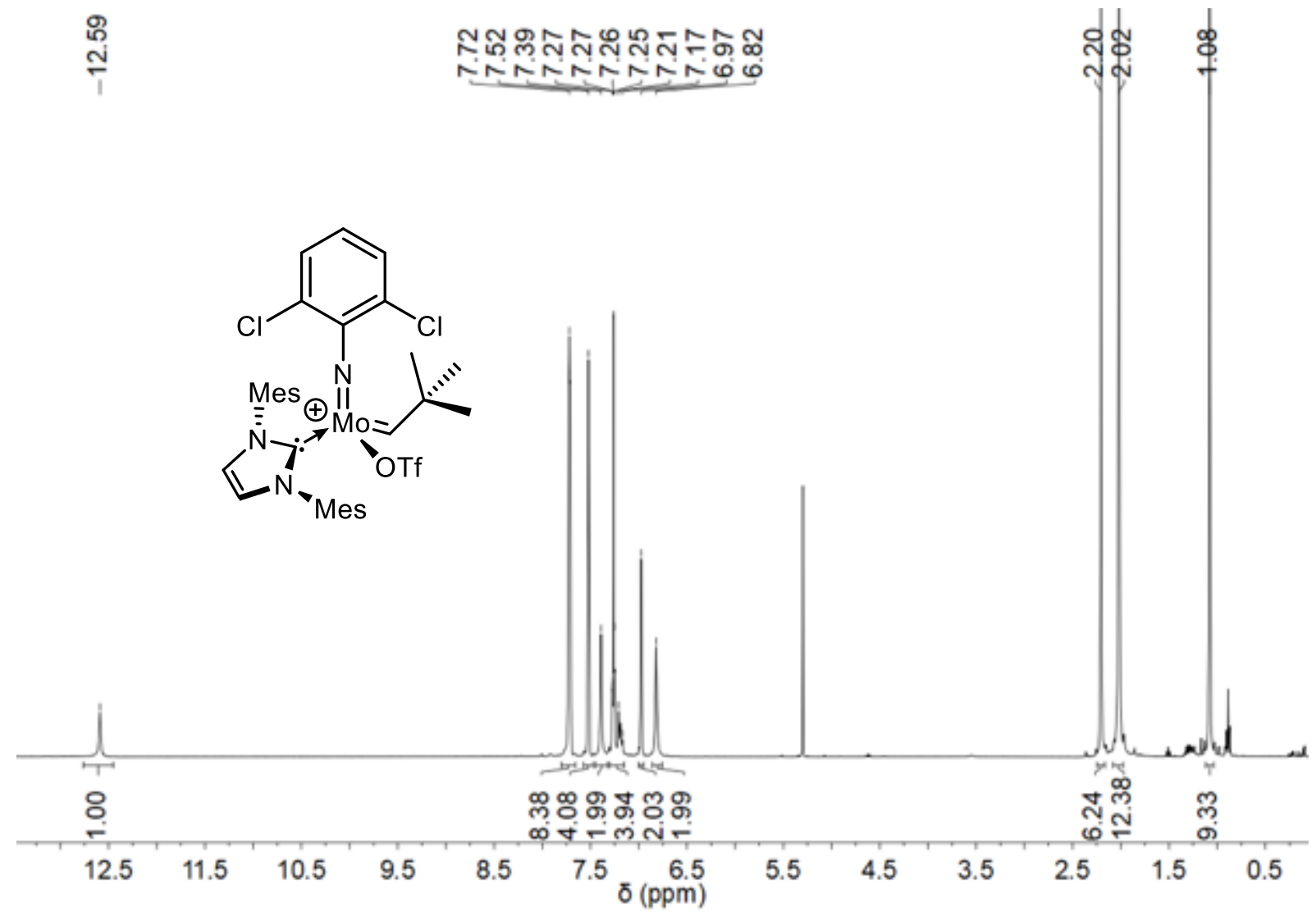

Figure S47: ${ }^{1} \mathrm{H}-\mathrm{NMR}$ spectrum $(400 \mathrm{MHz})$ of initiator I18 in $\mathrm{CDCl}_{3}$. 


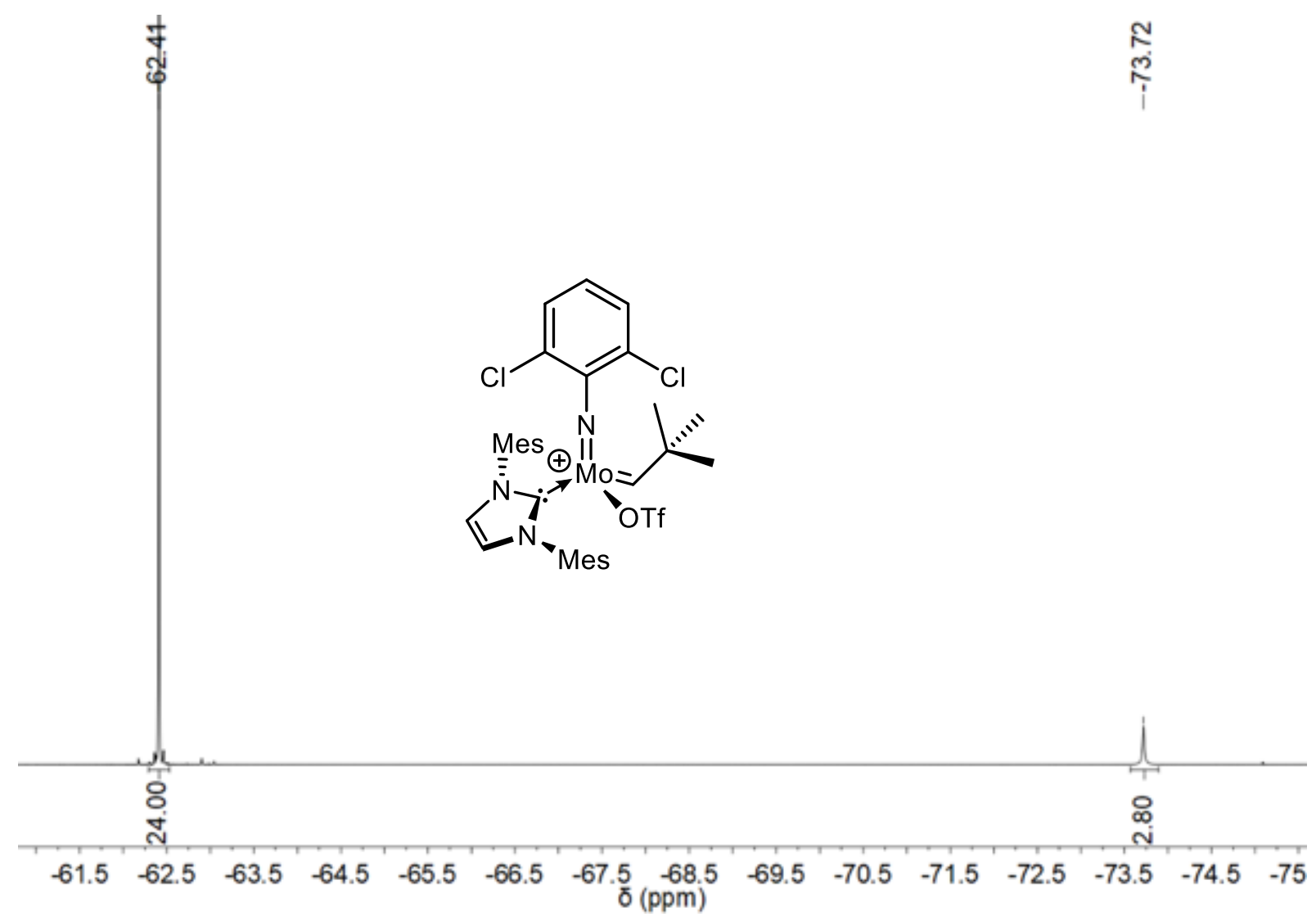

Figure S48: ${ }^{19} \mathrm{~F}-\mathrm{NMR}$ spectrum $\left(376 \mathrm{MHz}\right.$ ) of initiator $\mathbf{I 1 8}$ in $\mathrm{CDCl}_{3}$.

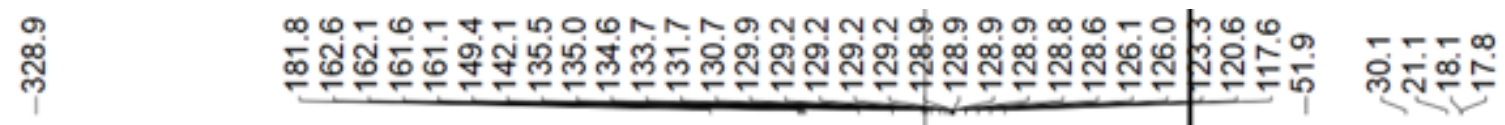

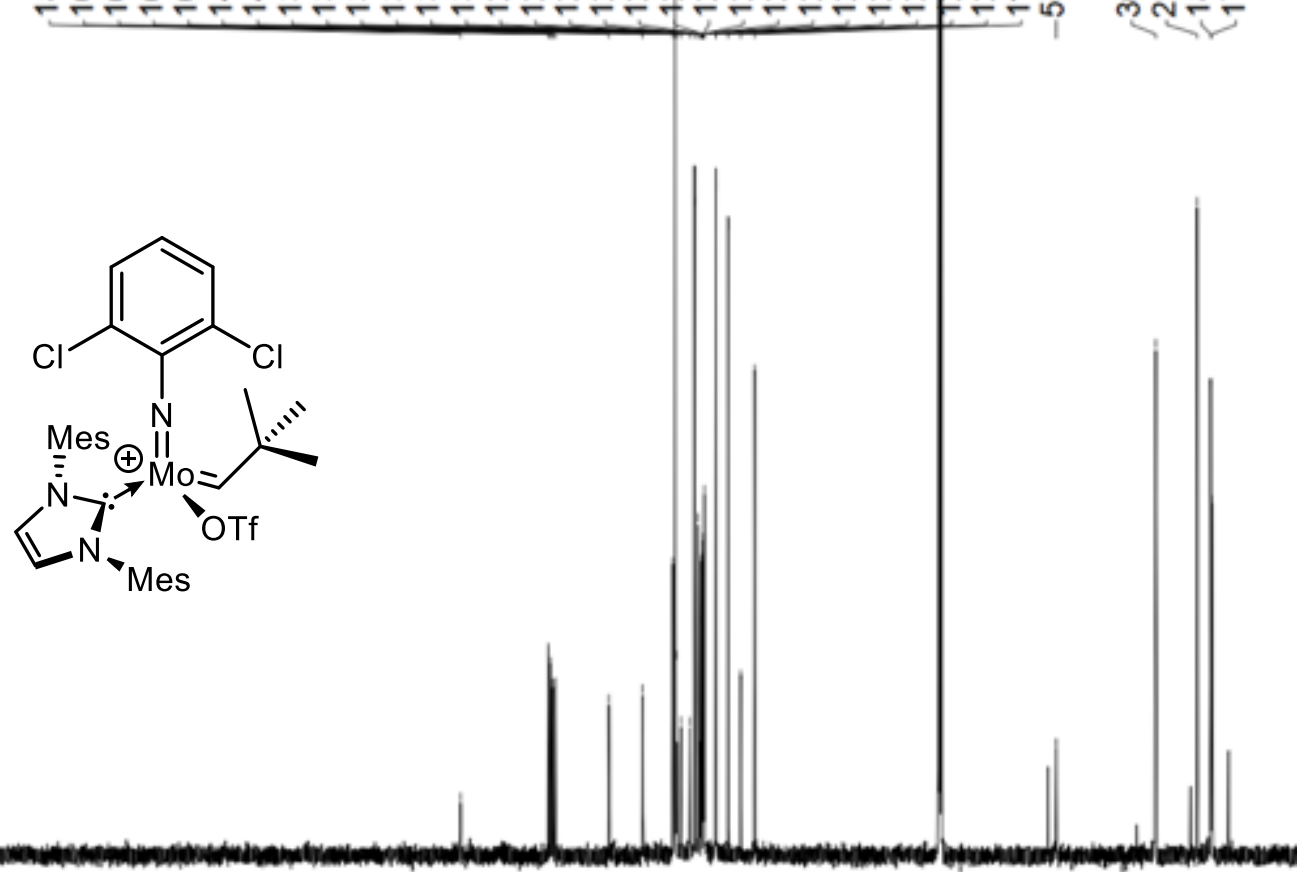

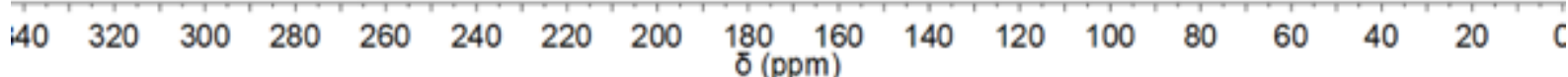

Figure S49: ${ }^{13} \mathrm{C}-\mathrm{NMR}$ spectrum $(101 \mathrm{MHz})$ of initiator I18 in $\mathrm{CDCl}_{3}$. 


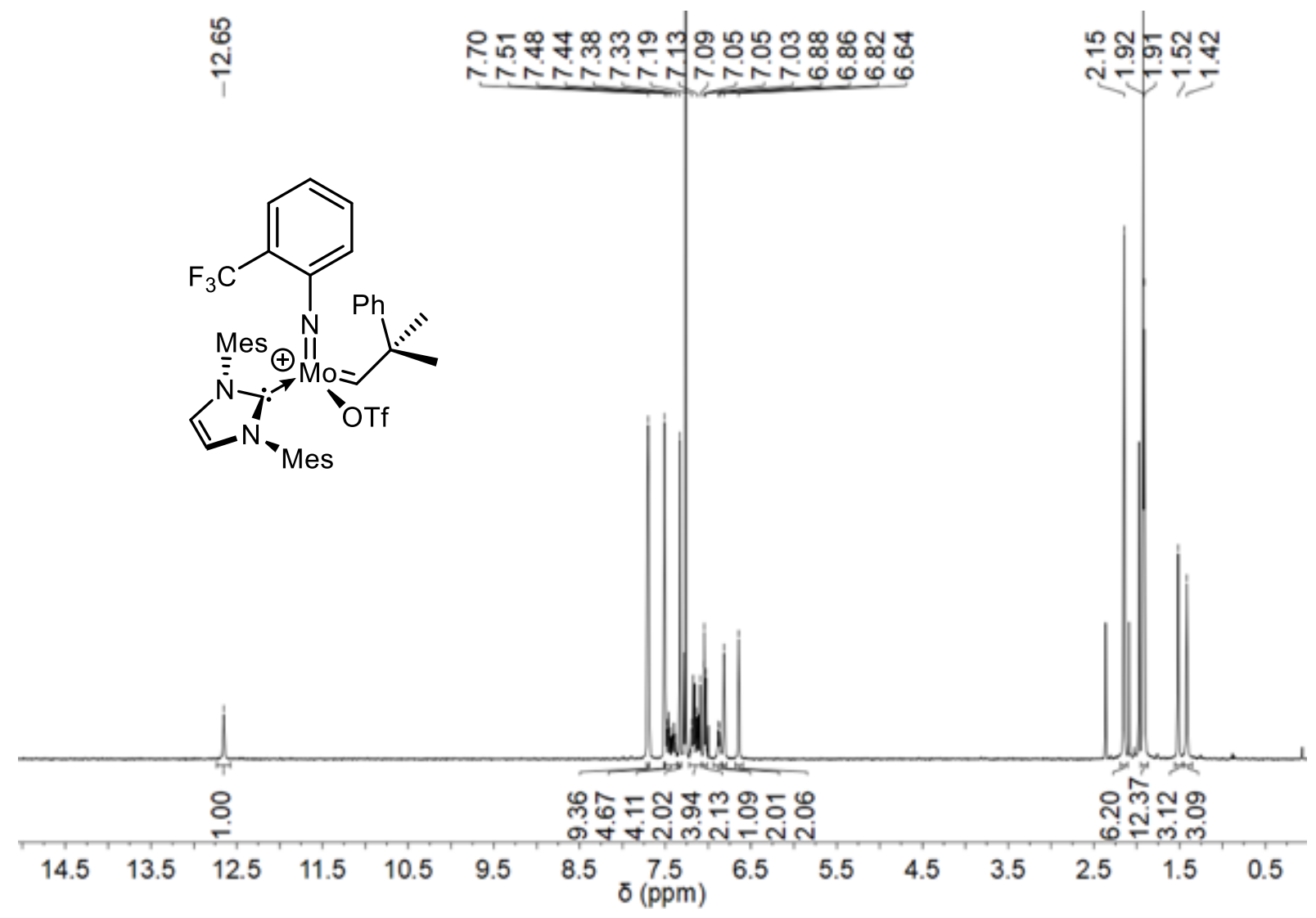

Figure S50: ${ }^{1} \mathrm{H}-\mathrm{NMR}$ spectrum $(400 \mathrm{MHz})$ of initiator I19 in $\mathrm{CDCl}_{3}$.

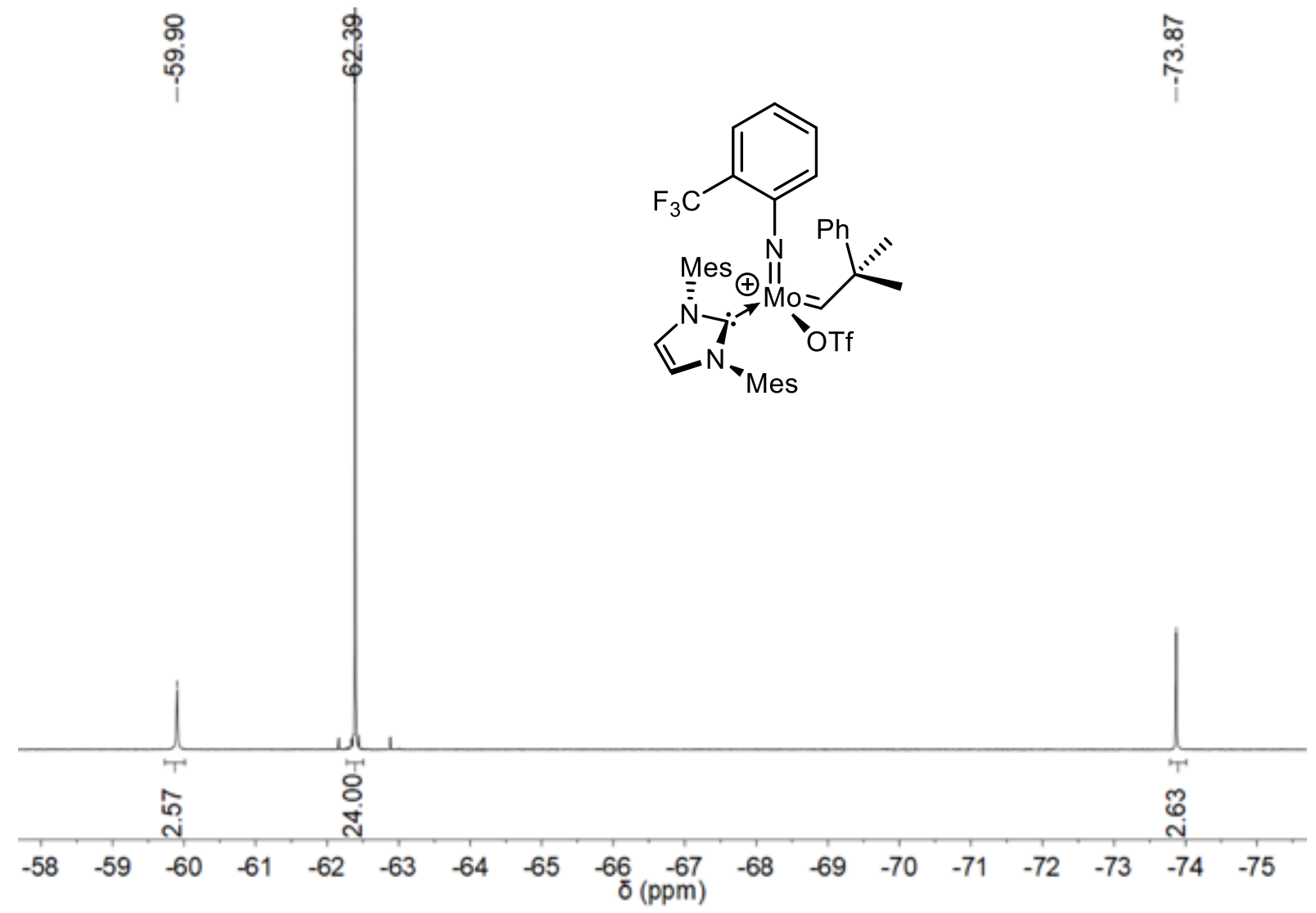

Figure S51: ${ }^{19} \mathrm{~F}-\mathrm{NMR}$ spectrum $(376 \mathrm{MHz})$ of initiator I19 in $\mathrm{CDCl}_{3}$. 


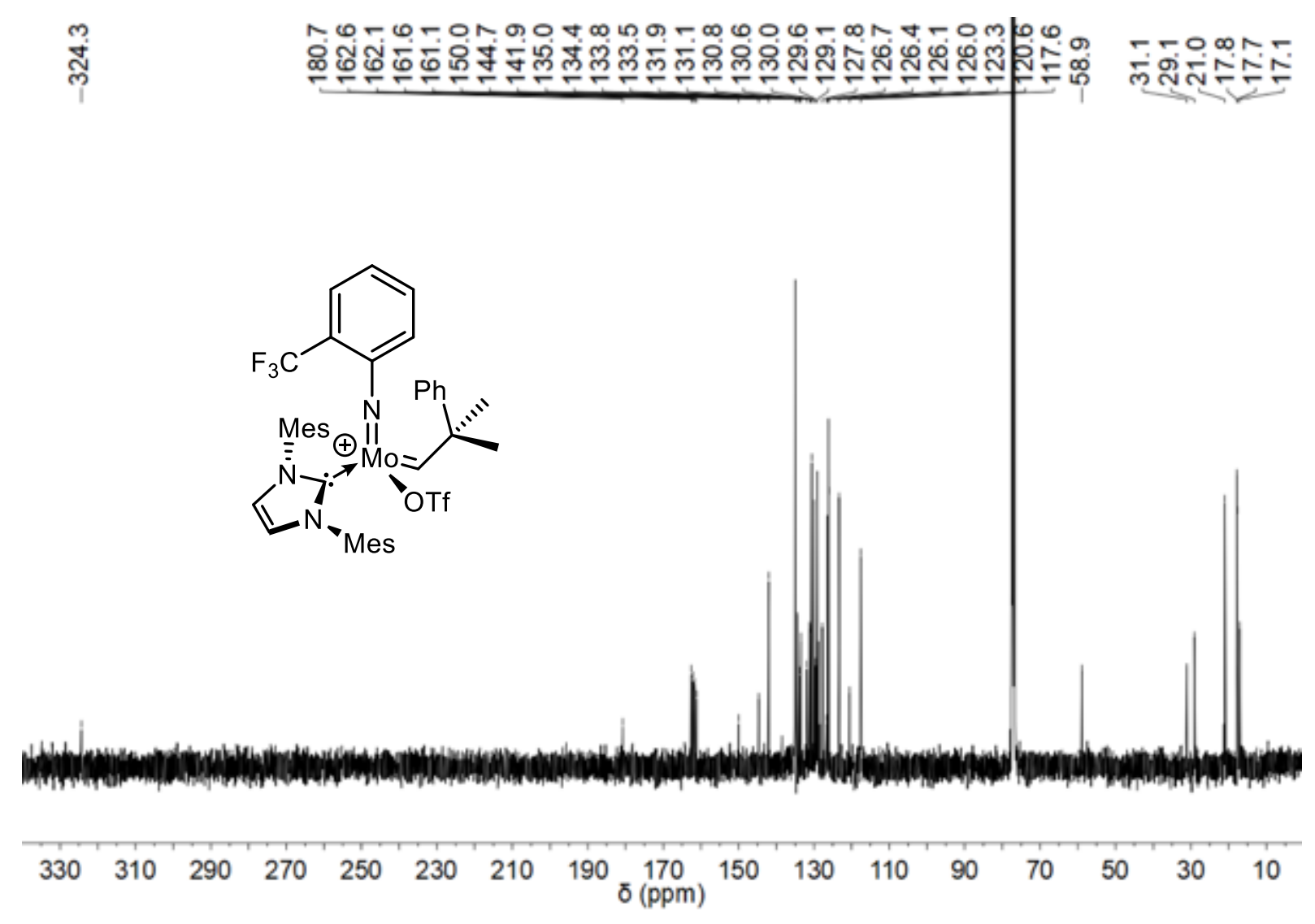

Figure S52: ${ }^{13} \mathrm{C}-\mathrm{NMR}$ spectrum $(101 \mathrm{MHz})$ of initiator I19 in $\mathrm{CDCl}_{3}$.
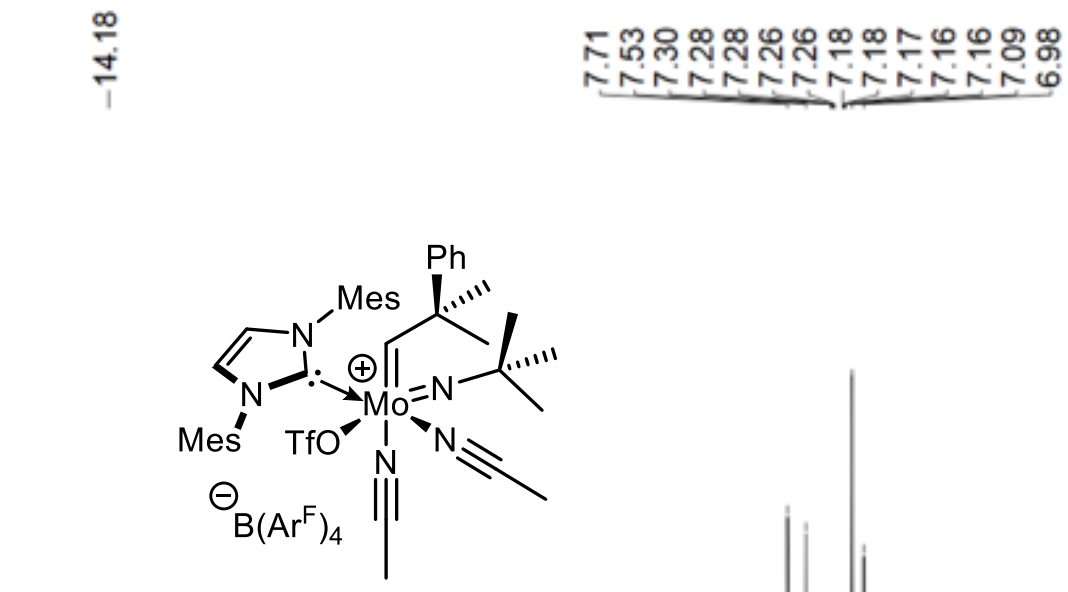

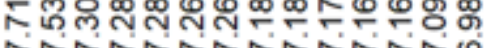

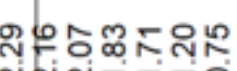

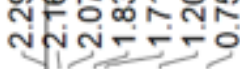

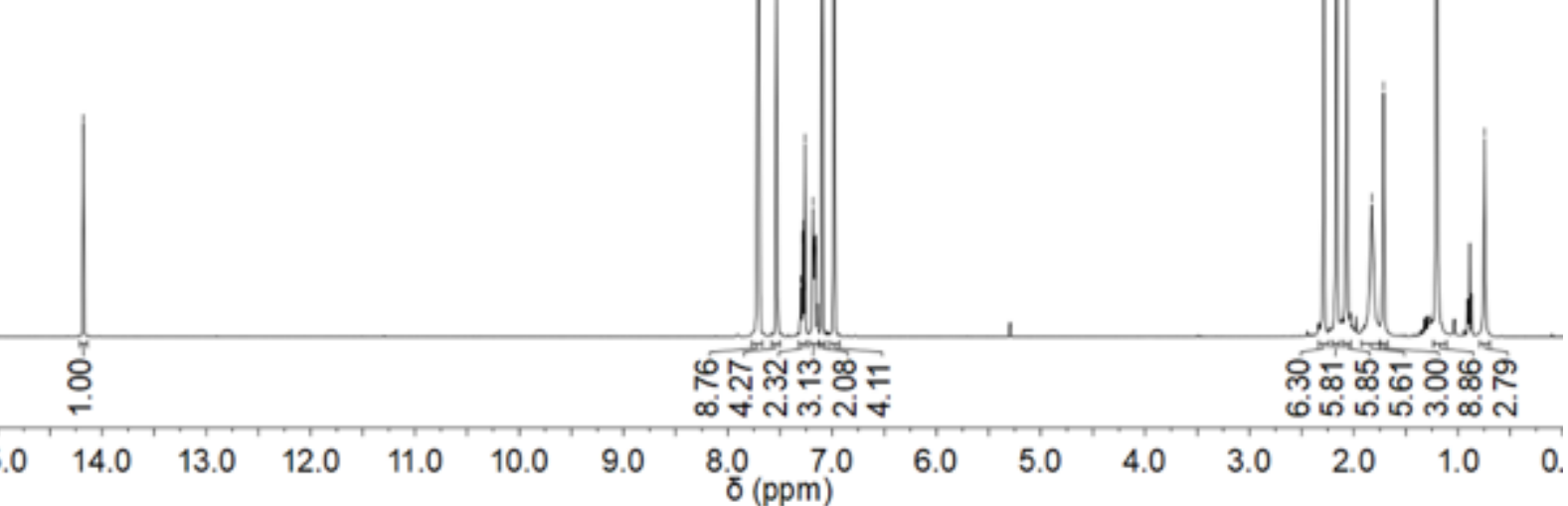

Figure S53: ${ }^{1} \mathrm{H}-\mathrm{NMR}$ spectrum $(400 \mathrm{MHz})$ of initiator $\mathbf{I 2 0}$ in $\mathrm{CDCl}_{3}$. 


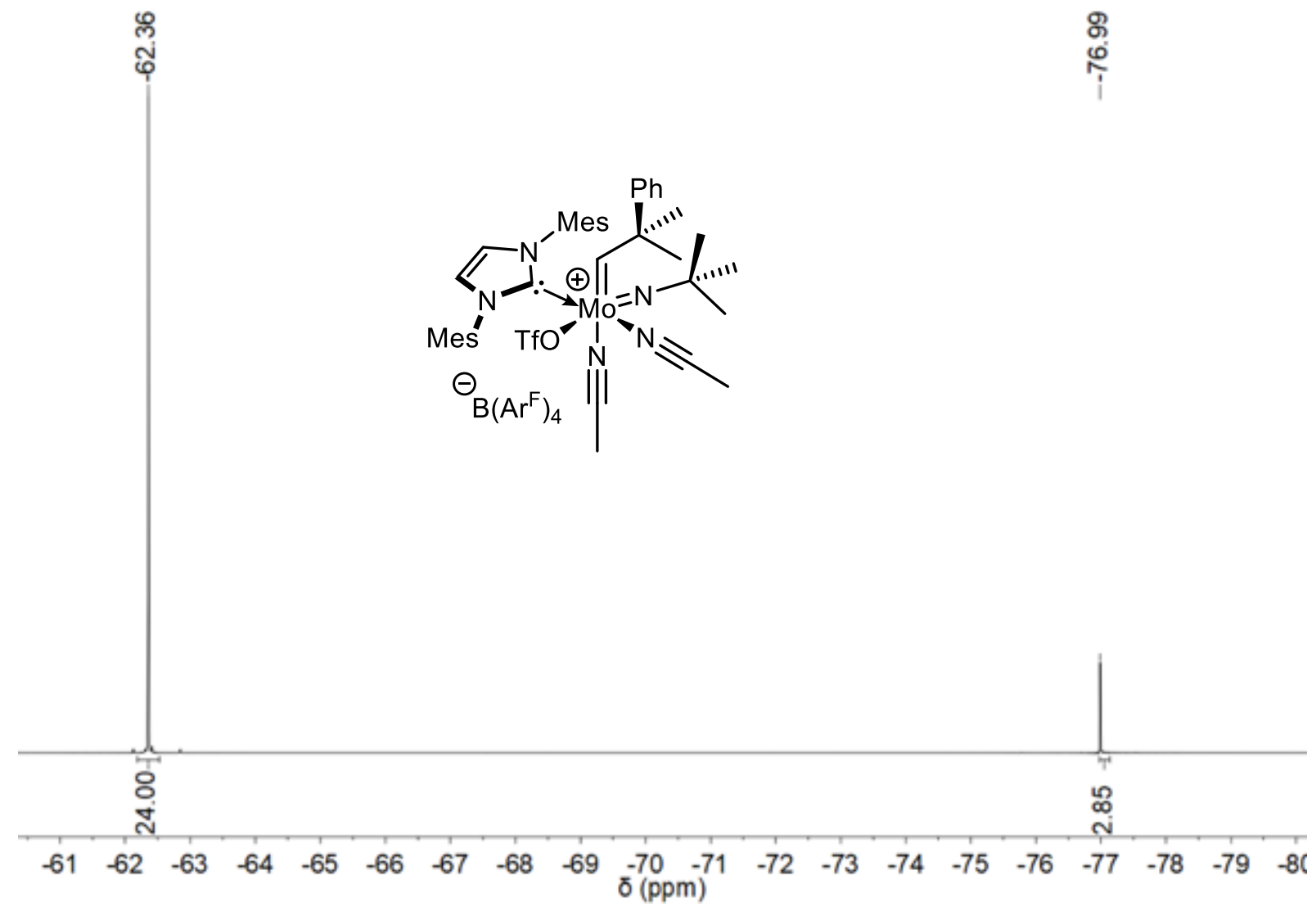

Figure S54: ${ }^{19} \mathrm{~F}-\mathrm{NMR}$ spectrum $(376 \mathrm{MHz})$ of initiator $\mathbf{I 2 0}$ in $\mathrm{CDCl}_{3}$.

กู

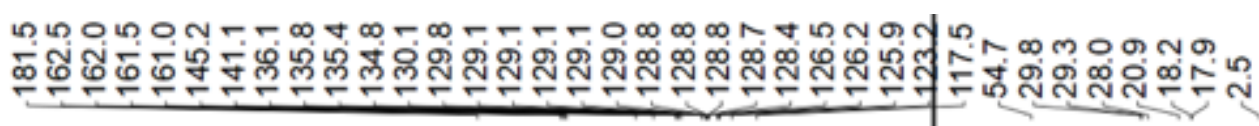

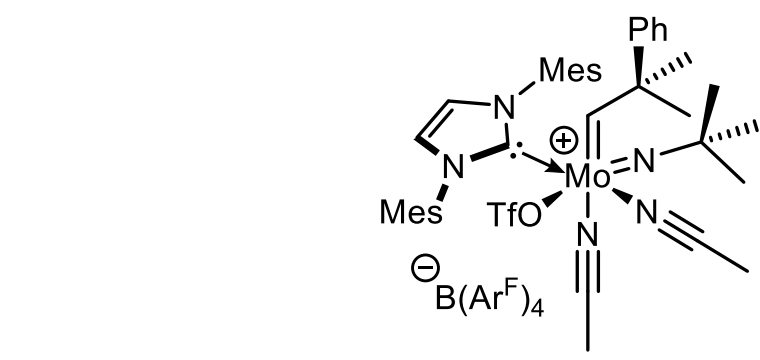

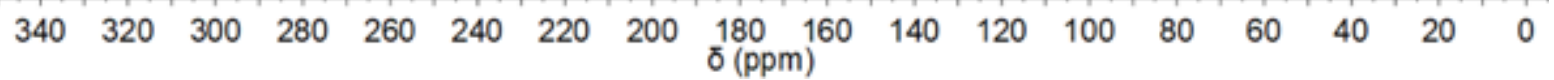

Figure S55: ${ }^{13} \mathrm{C}-\mathrm{NMR}$ spectrum $(101 \mathrm{MHz})$ of initiator $\mathbf{I 2 0}$ in $\mathrm{CDCl}_{3}$. 


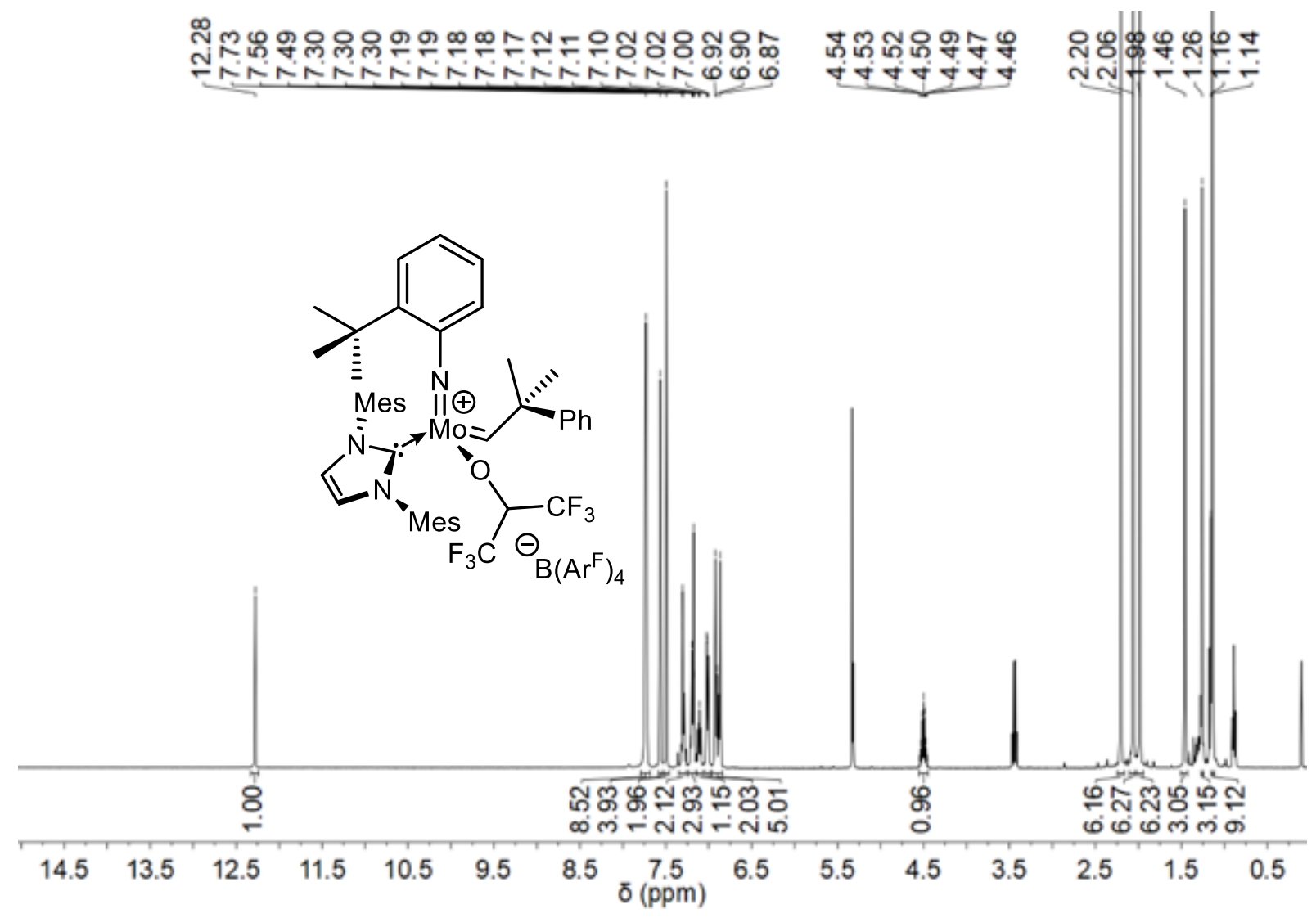

Figure S56: ${ }^{1} \mathrm{H}-\mathrm{NMR}(400 \mathrm{MHz})$ spectrum of initiator $\mathbf{I 2 1}$ in $\mathrm{CD}_{2} \mathrm{Cl}_{2}$.

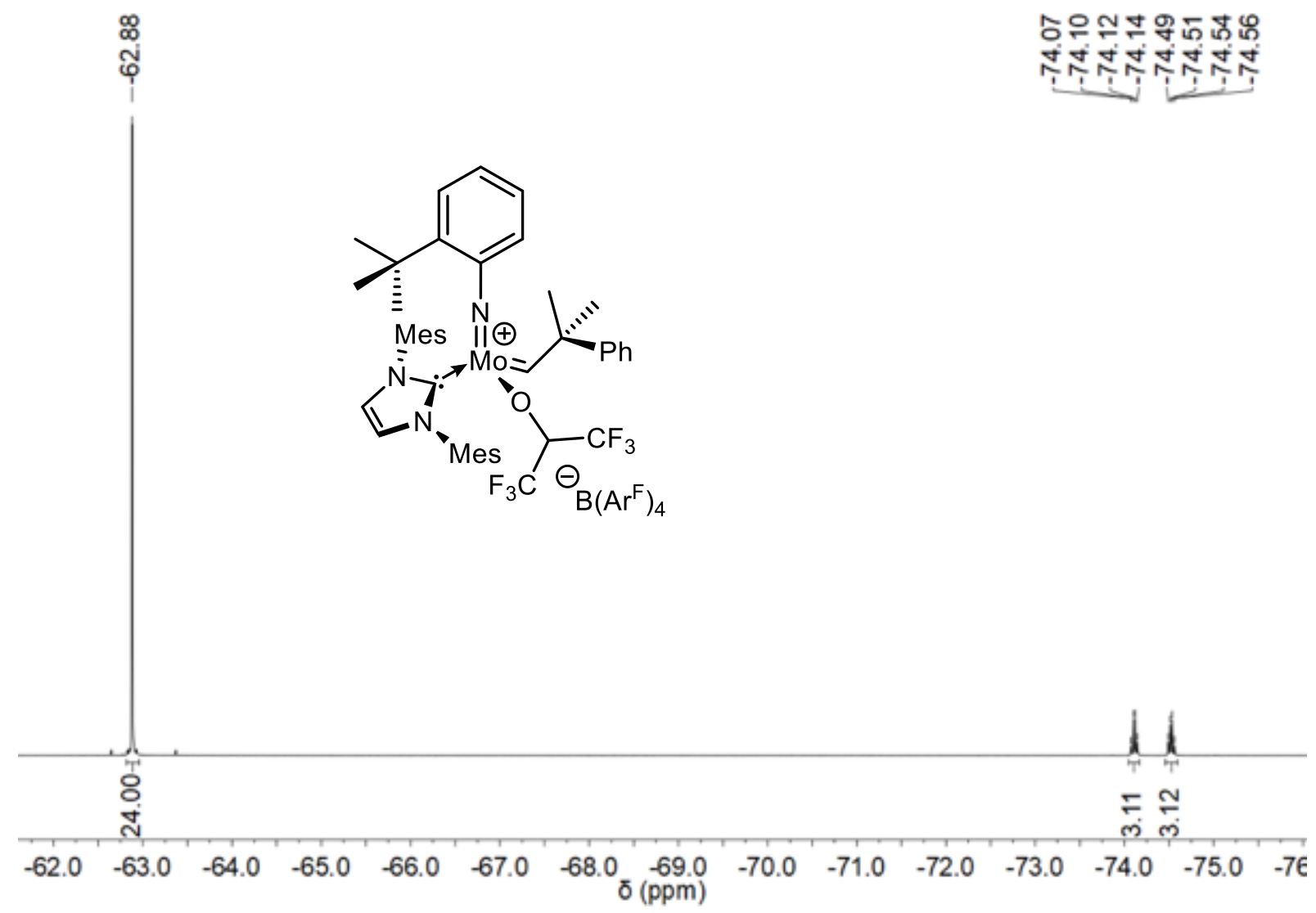

Figure S57: ${ }^{19} \mathrm{~F}-\mathrm{NMR}$ spectrum $\left(376 \mathrm{MHz}\right.$ ) of initiator $\mathbf{I} \mathbf{2 1}$ in $\mathrm{CD}_{2} \mathrm{Cl}_{2}$. 


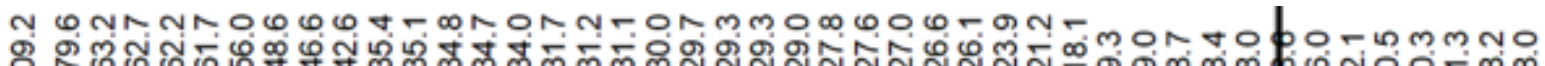
요

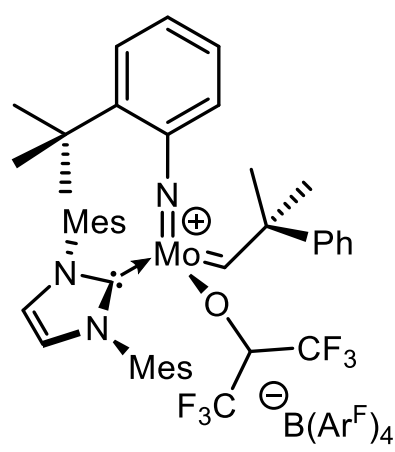

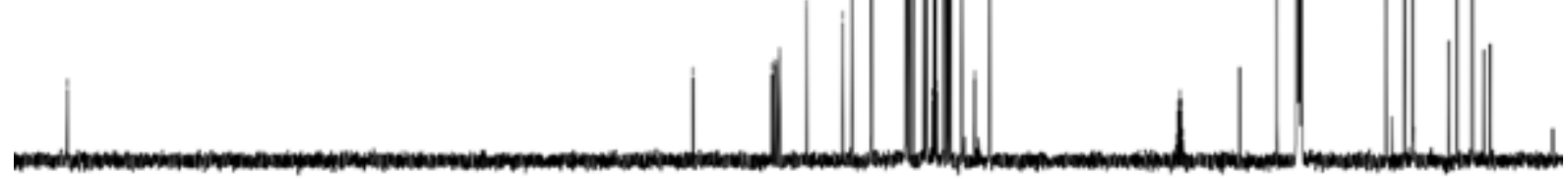

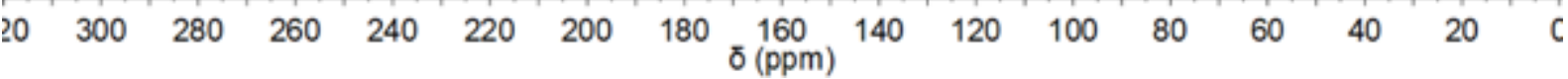

Figure S58: ${ }^{13} \mathrm{C}-\mathrm{NMR}$ spectrum $(101 \mathrm{MHz})$ of initiator $\mathbf{I 2 1}$ in $\mathrm{CD}_{2} \mathrm{Cl}_{2}$.

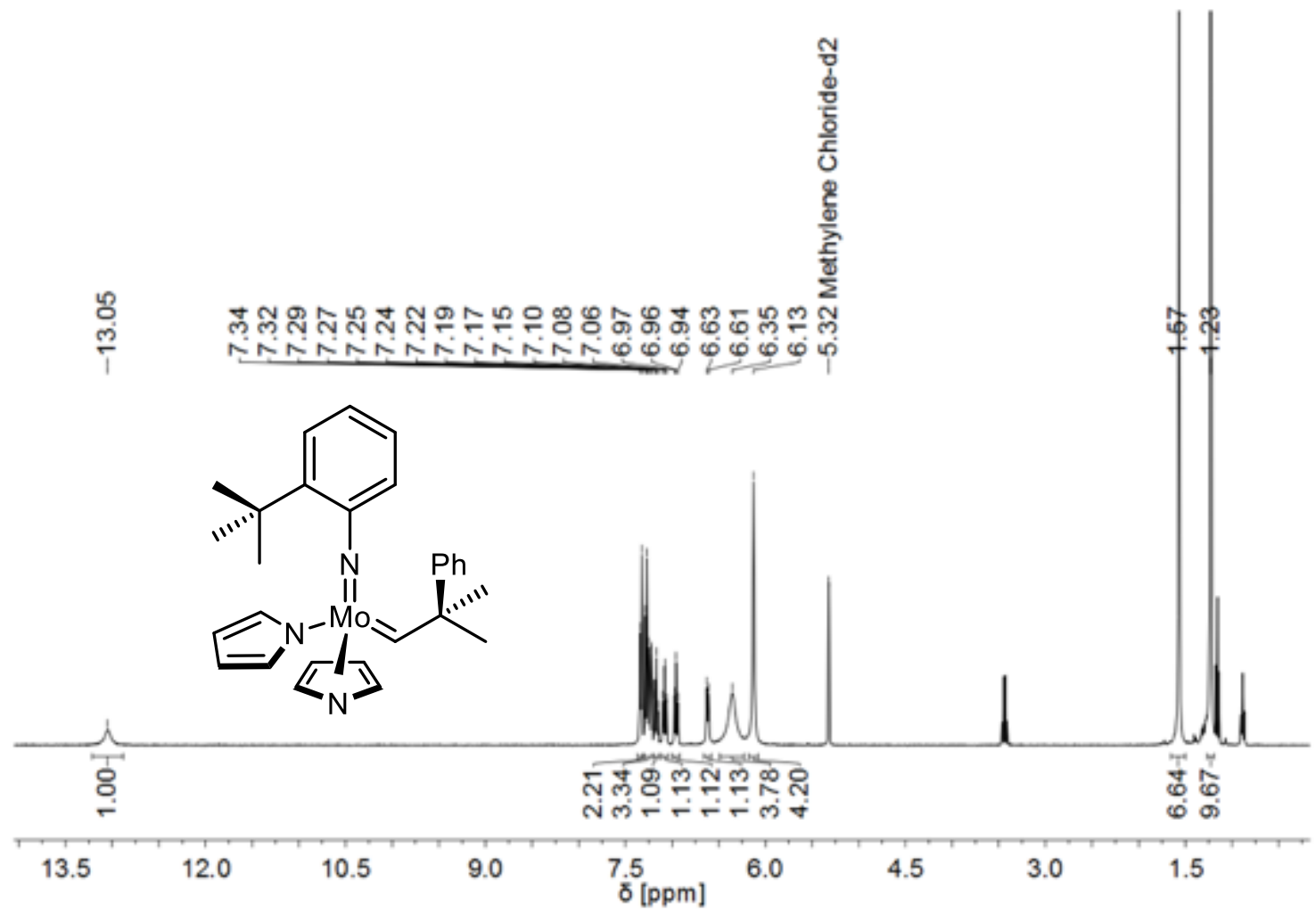

Figure S59: ${ }^{1} \mathrm{H}$ NMR spectrum $(400 \mathrm{MHz})$ of $\mathbf{M o - 1 . 0}$ in $\mathrm{CD}_{2} \mathrm{Cl}_{2}$. 


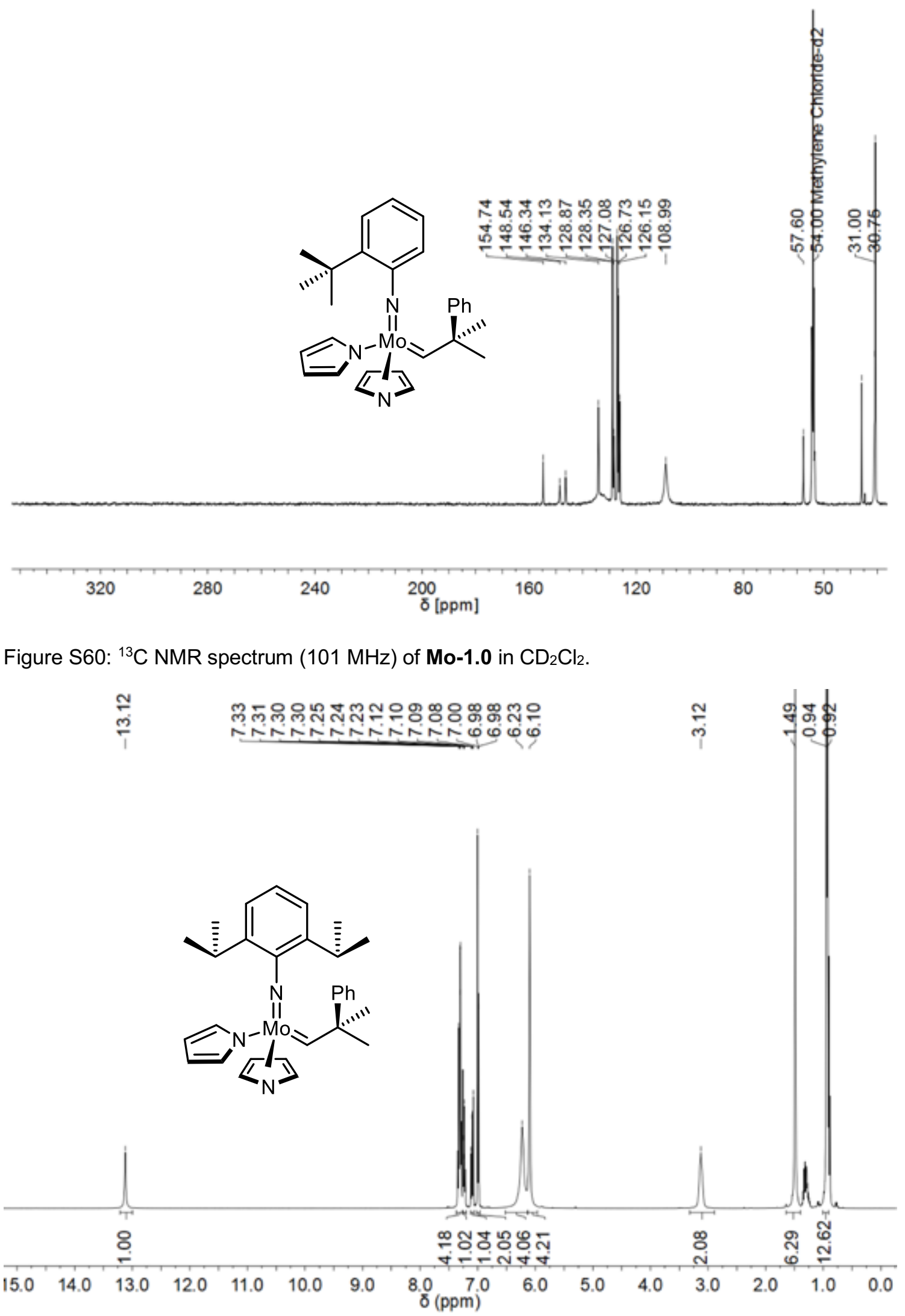

Figure S61: ${ }^{1} \mathrm{H}$ NMR spectrum $(400 \mathrm{MHz})$ of $\mathbf{M o - 3 . 0}$ in $\mathrm{CDCl}_{3}$. 
号

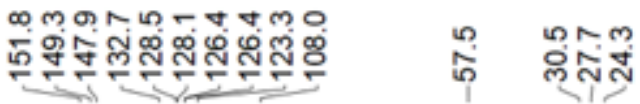

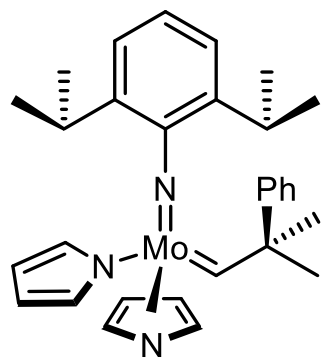

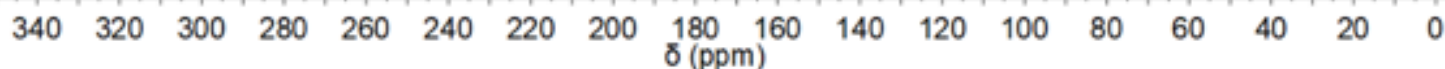

Figure S62: ${ }^{13} \mathrm{C}$ NMR spectrum $(101 \mathrm{MHz})$ of $\mathbf{M o - 3 . 0}$ in $\mathrm{CDCl}_{3}$.

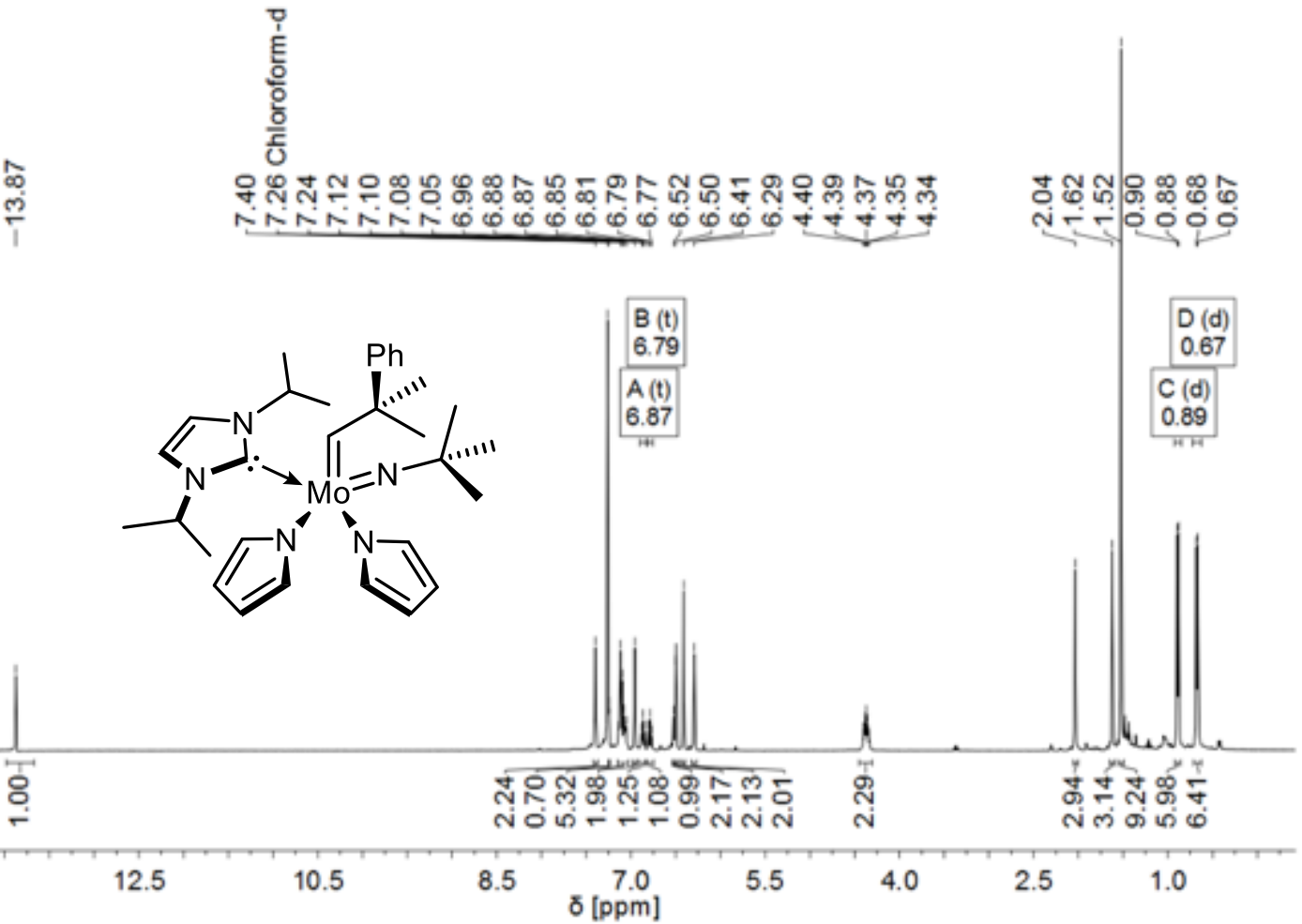

Figure S63: ${ }^{1} \mathrm{H}$ NMR spectrum $(400 \mathrm{MHz})$ of $\mathrm{Mo}-1.1$ in $\mathrm{CDCl}_{3}$. 


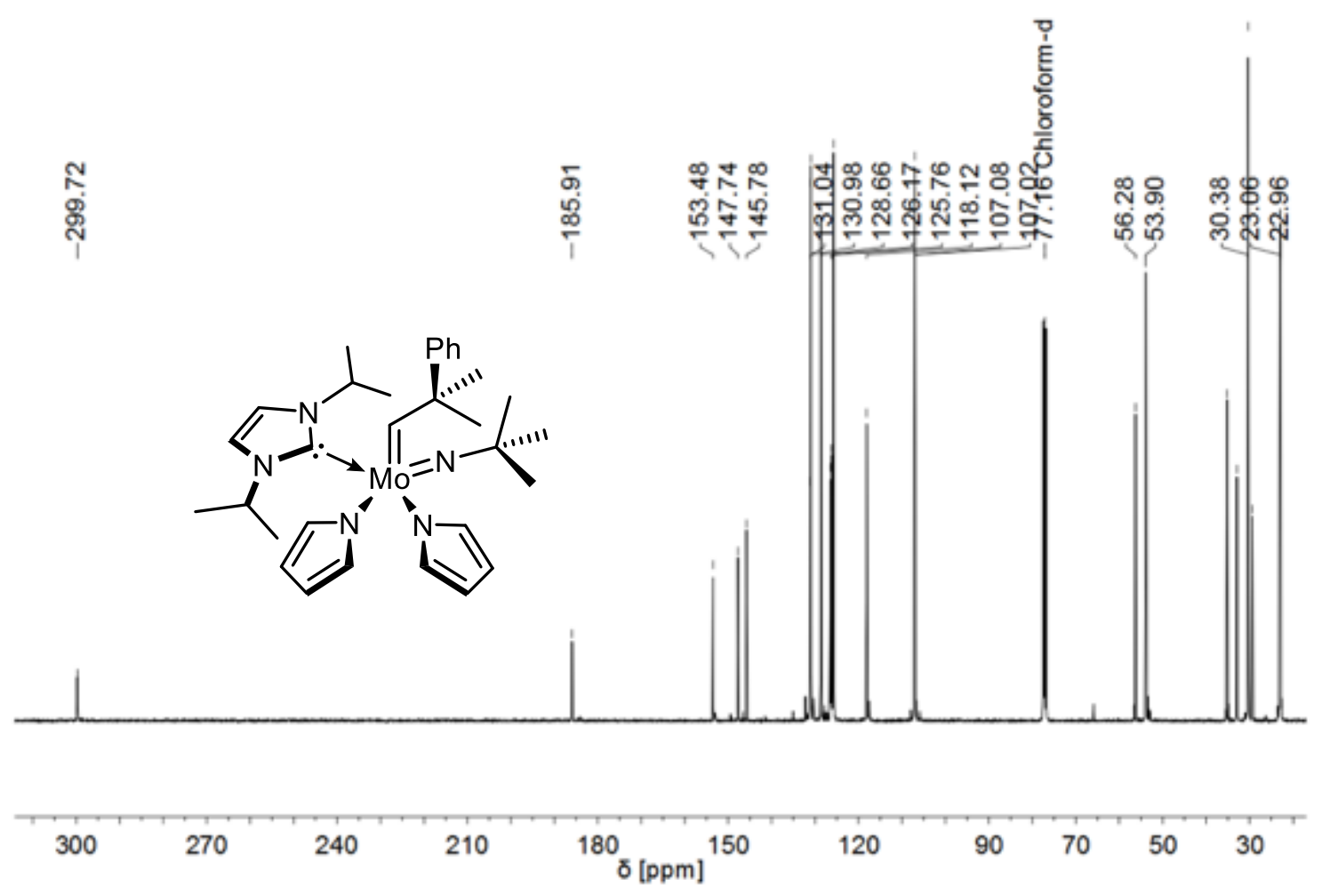

Figure S64: ${ }^{13} \mathrm{C}$ NMR spectrum $(101 \mathrm{MHz})$ of $\mathrm{Mo-1.1}$ in $\mathrm{CDCl}_{3}$.

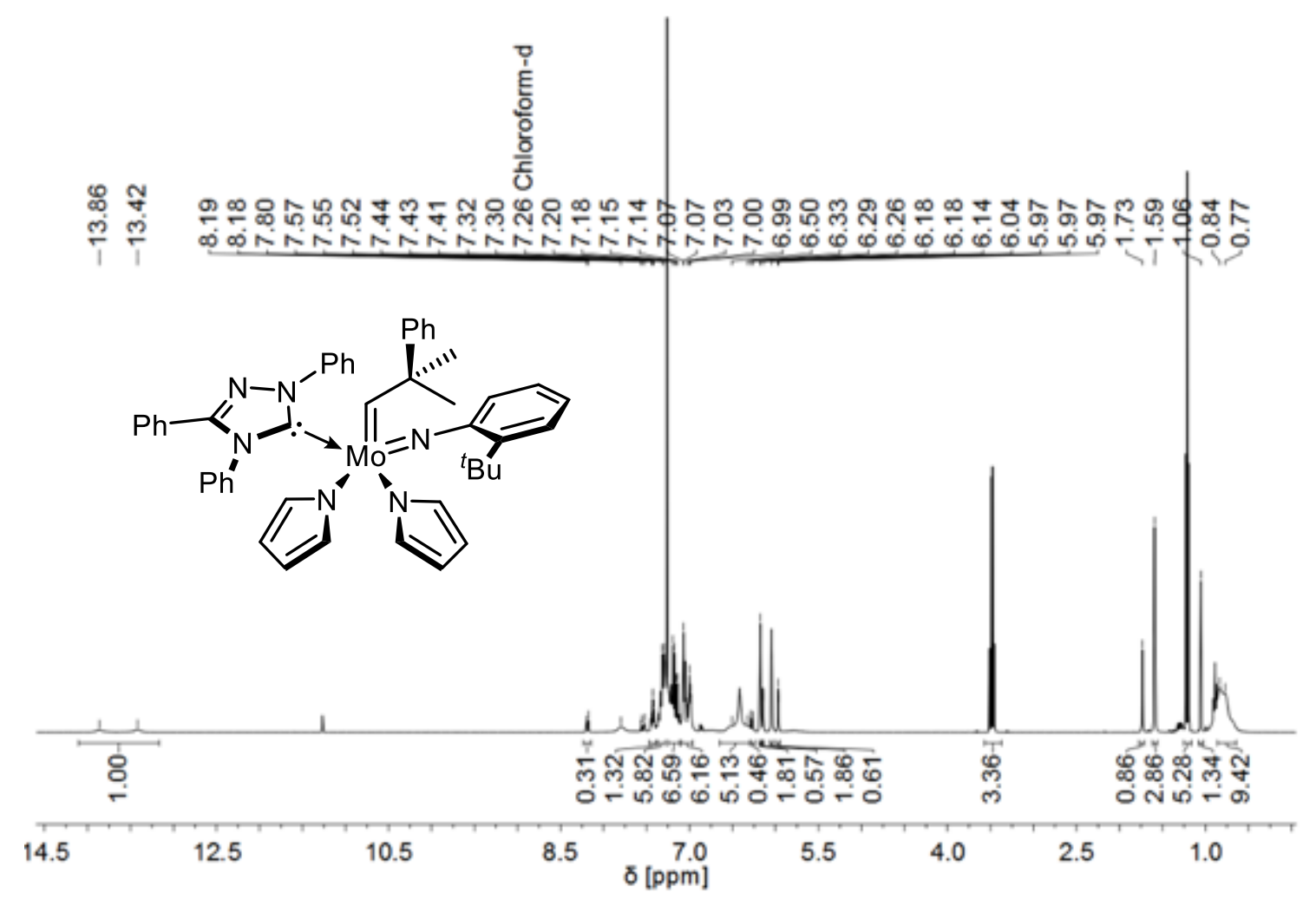

Figure S65: ${ }^{1} \mathrm{H}$ NMR spectrum $(400 \mathrm{MHz})$ of $\mathrm{Mo-1.2}$ in $\mathrm{CDCl}_{3}$. 


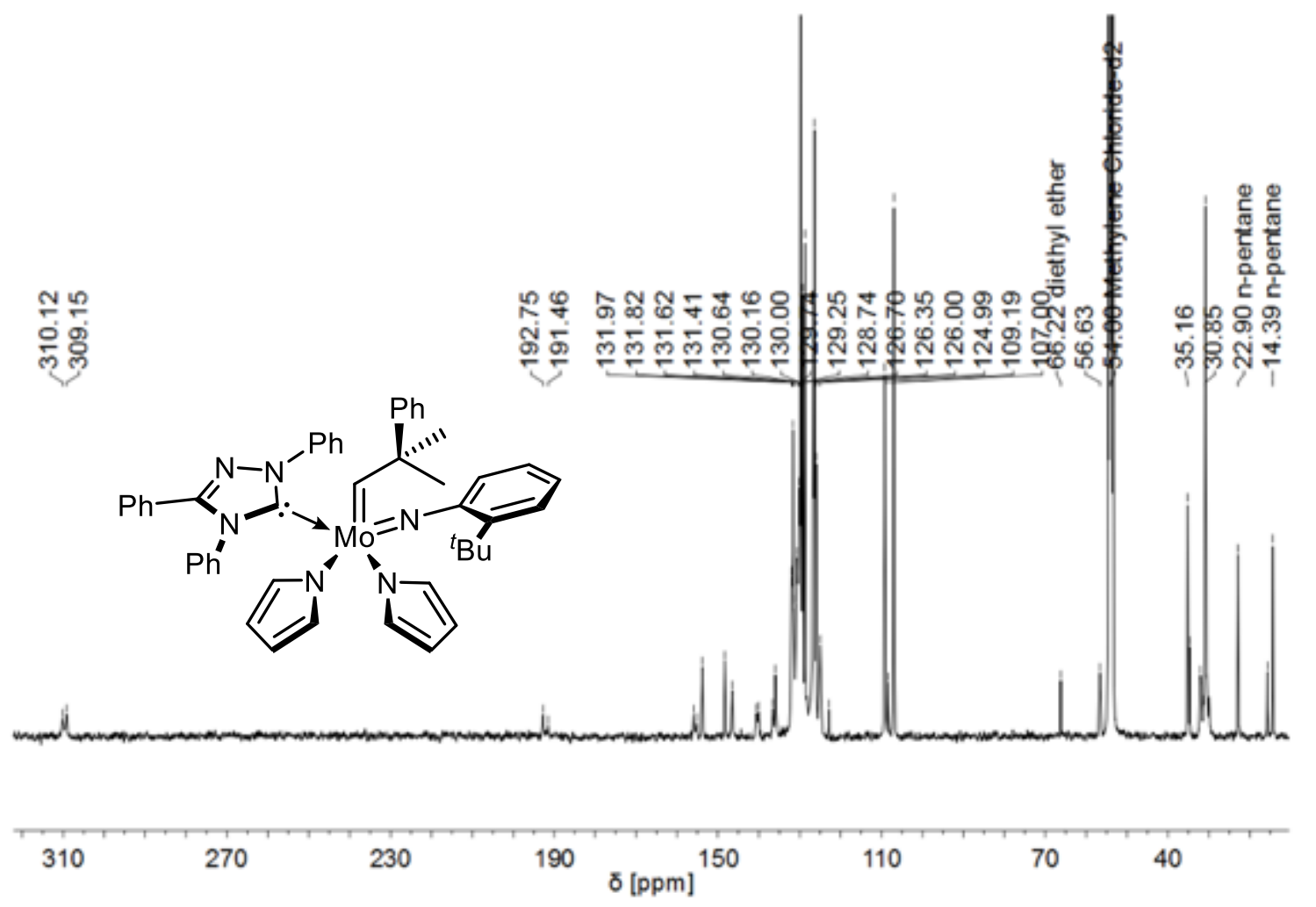

Figure S66: ${ }^{13} \mathrm{C}$ NMR spectrum (101 MHz) of Mo-1.2 in $\mathrm{CDCl}_{3}$.

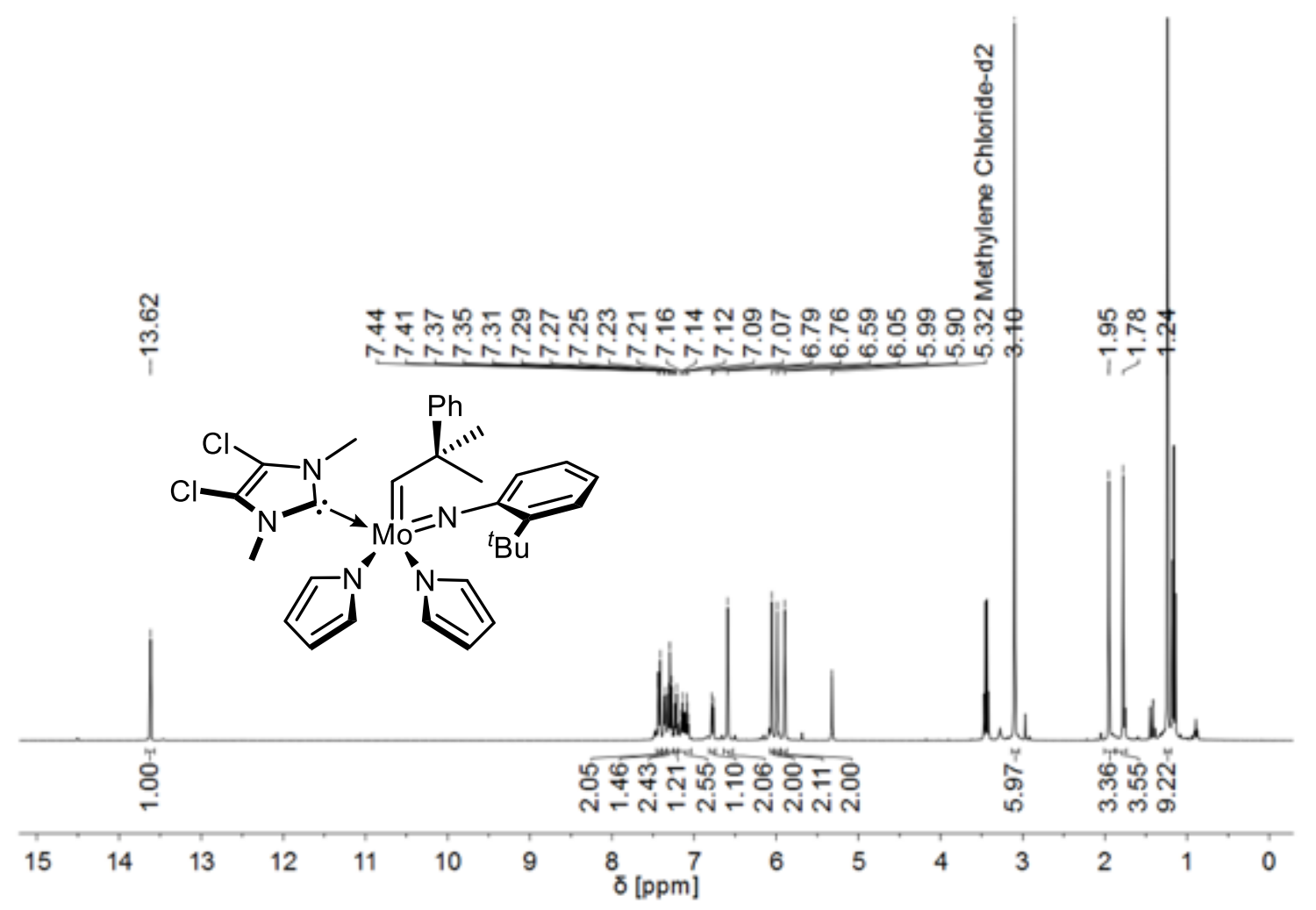

Figure S67: ${ }^{1} \mathrm{H}$ NMR spectrum $(400 \mathrm{MHz})$ of $\mathrm{Mo-1.3}$ in $\mathrm{CD}_{2} \mathrm{Cl}_{2}$. 


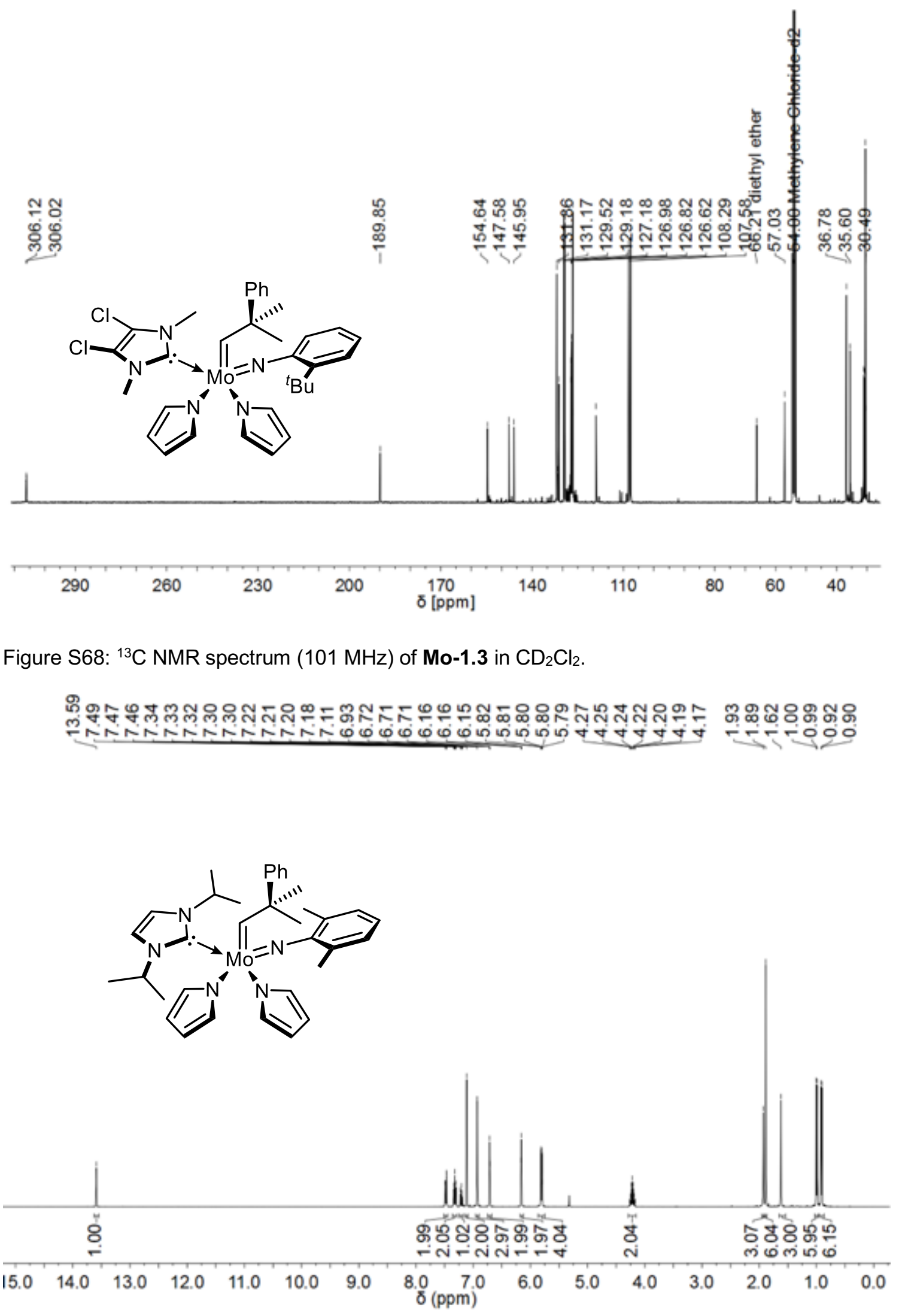

Figure S69: ${ }^{1} \mathrm{H}$ NMR spectrum $(400 \mathrm{MHz})$ of $\mathbf{M o}-2.1$ in $\mathrm{CDCl}_{3}$. 


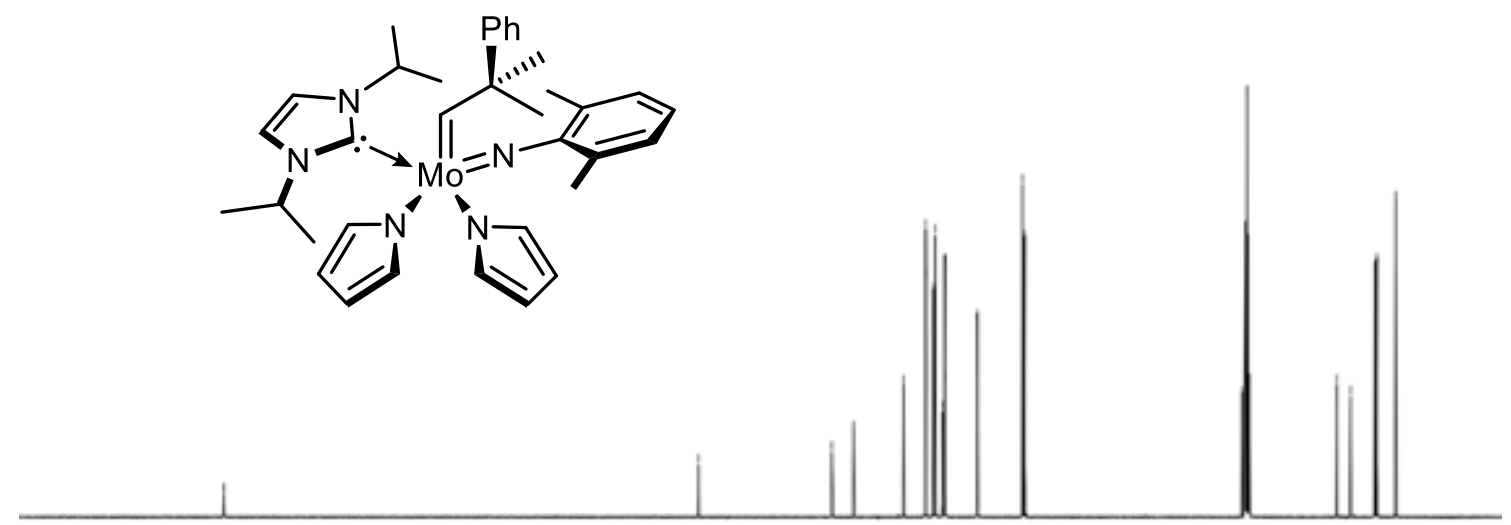

$\begin{array}{lllllllllllllllll}340 & 320 & 300 & 280 & 260 & 240 & 220 & 200 & \begin{array}{c}180 \\ \delta(\mathrm{ppm})\end{array} & 140 & 120 & 100 & 80 & 60 & 40 & 20 & 0\end{array}$

Figure S70: ${ }^{13} \mathrm{C}$ NMR spectrum $(101 \mathrm{MHz})$ of $\mathbf{M o - 2 . 1}$ in $\mathrm{CDCl}_{3}$.

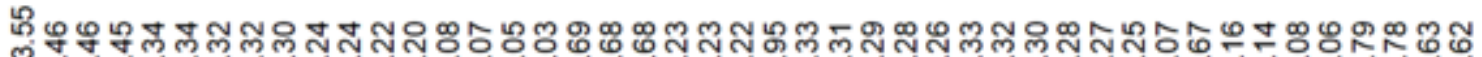

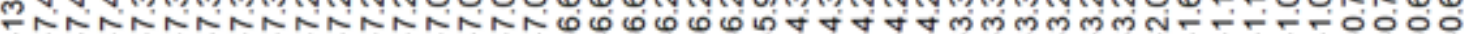

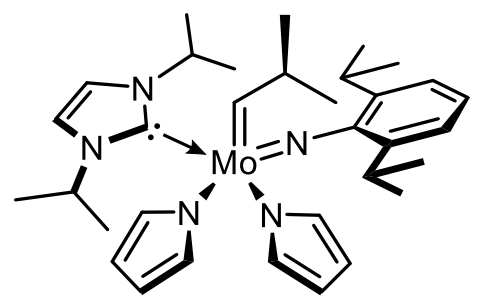

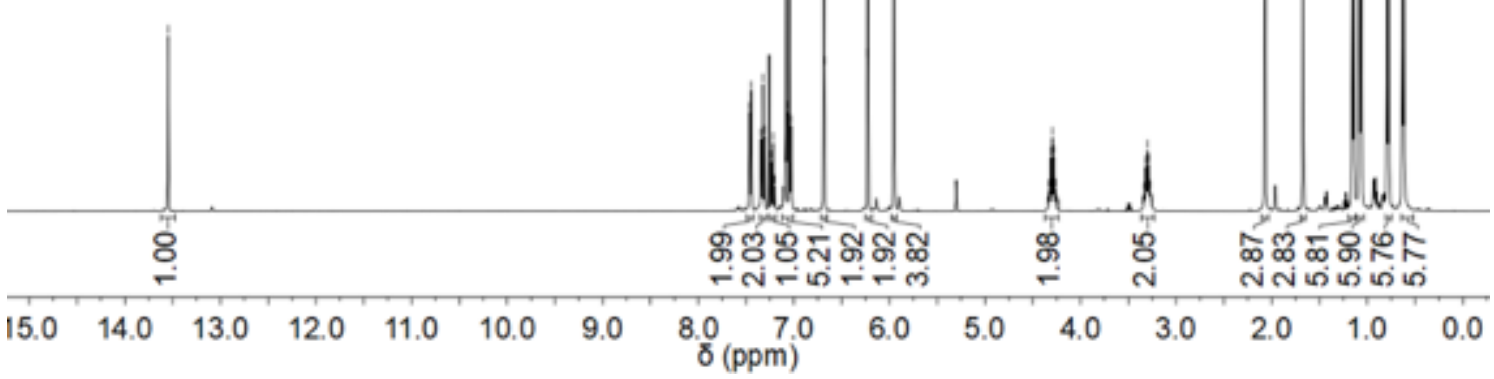

Figure S71: ${ }^{1} \mathrm{H}$ NMR spectrum $(400 \mathrm{MHz})$ of $\mathrm{Mo-3.1}$ in $\mathrm{CDCl}_{3}$. 


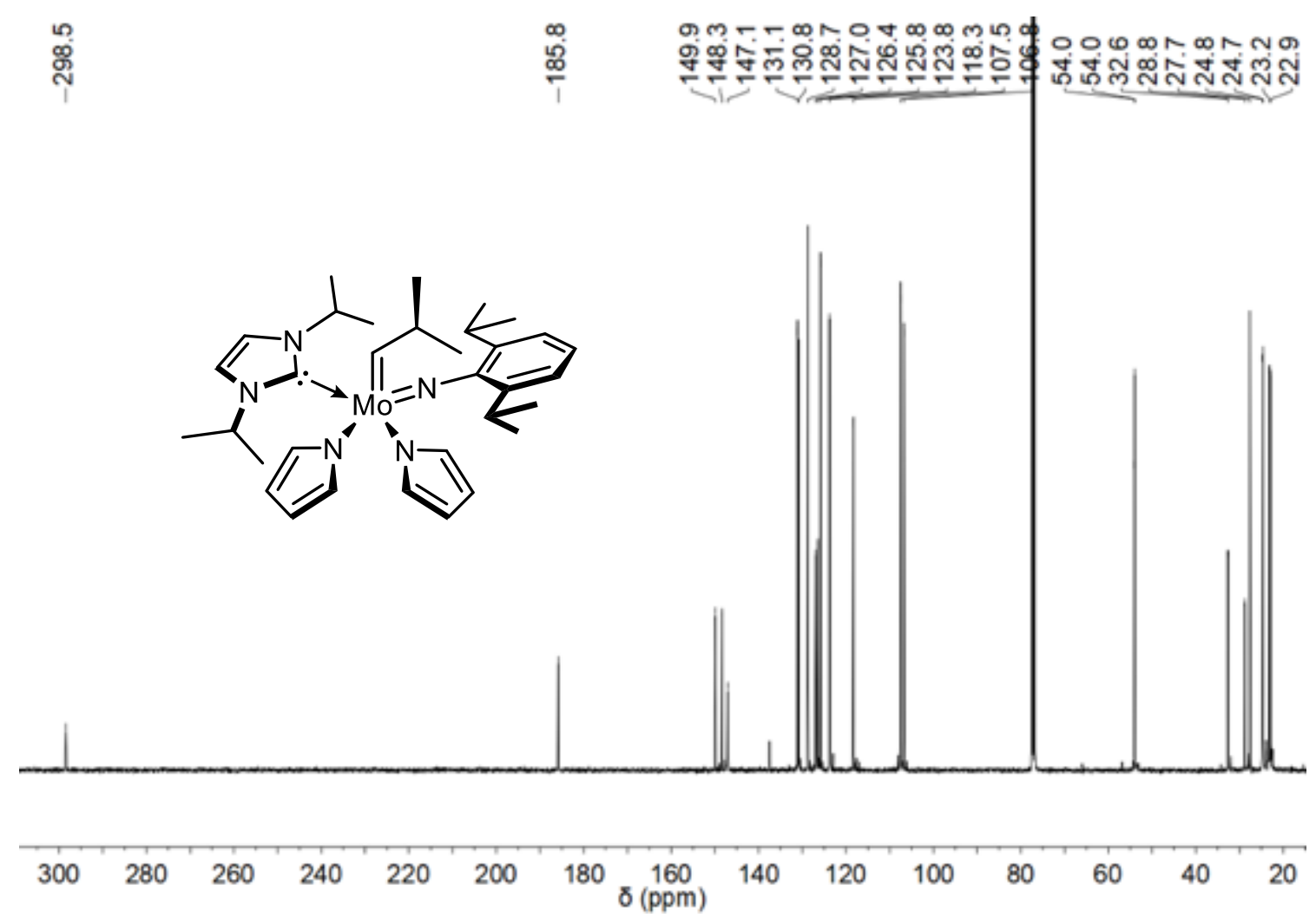

Figure S72: ${ }^{13} \mathrm{C}$ NMR spectrum $(101 \mathrm{MHz})$ of $\mathrm{Mo}-3.1$ in $\mathrm{CDCl}_{3}$.
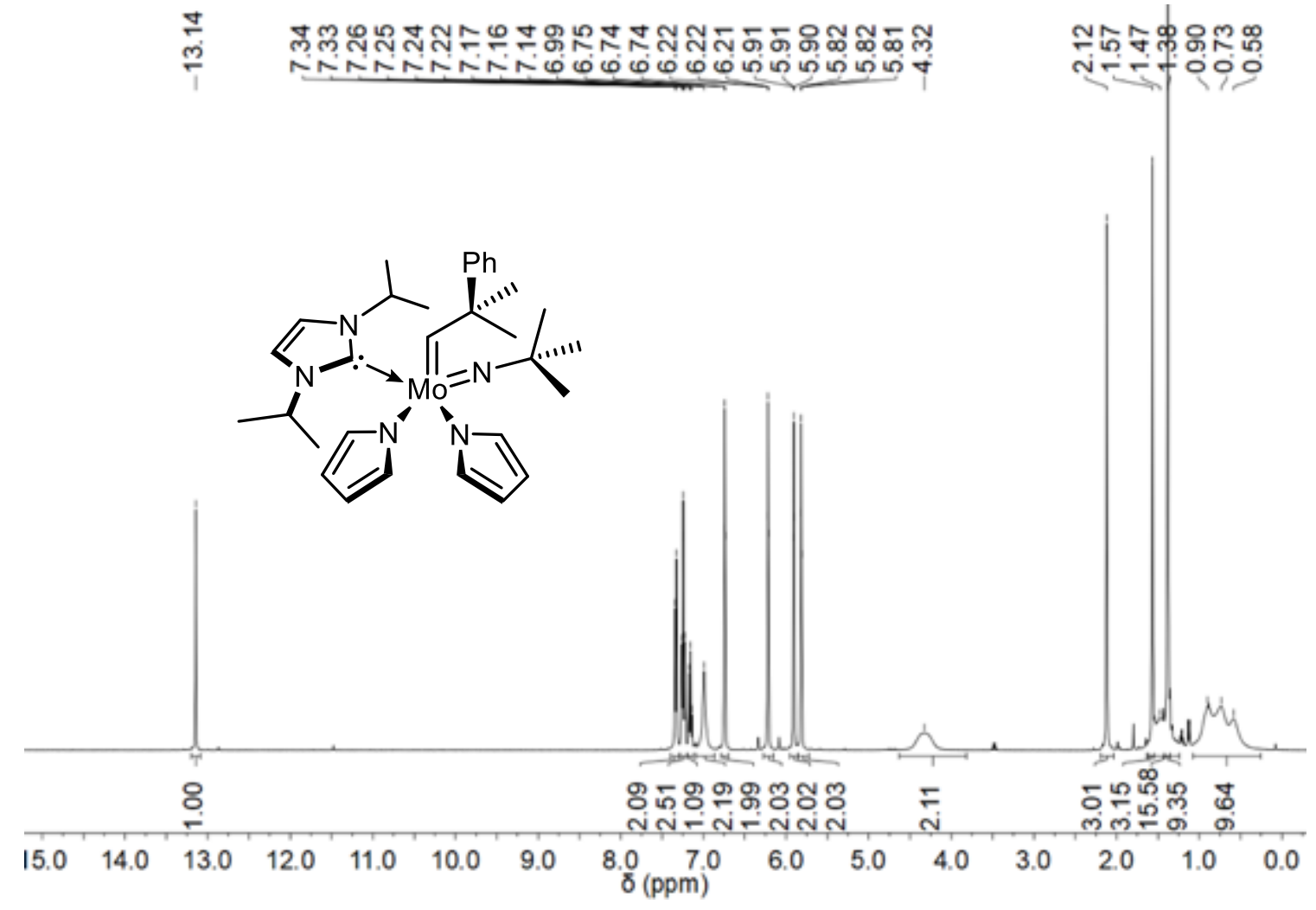

Figure S73: ${ }^{1} \mathrm{H}$ NMR spectrum $(400 \mathrm{MHz})$ of $\mathbf{M o - 4 . 1}$ in $\mathrm{CDCl}_{3}$. 
$\stackrel{m}{\stackrel{m}{\sim}}$

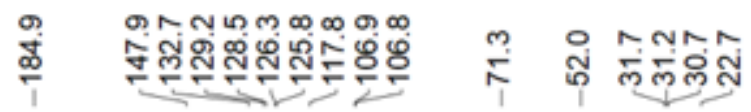

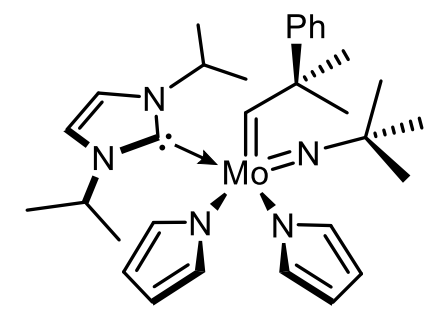

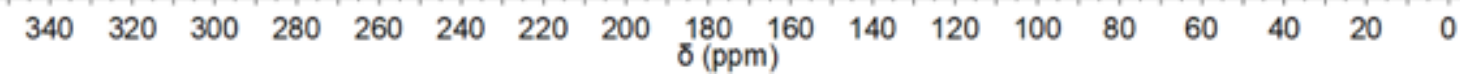

Figure S74: ${ }^{13} \mathrm{C}$ NMR spectrum $\left(101 \mathrm{MHz}\right.$ ) of $\mathrm{Mo-4.1}$ in $\mathrm{CDCl}_{3}$.

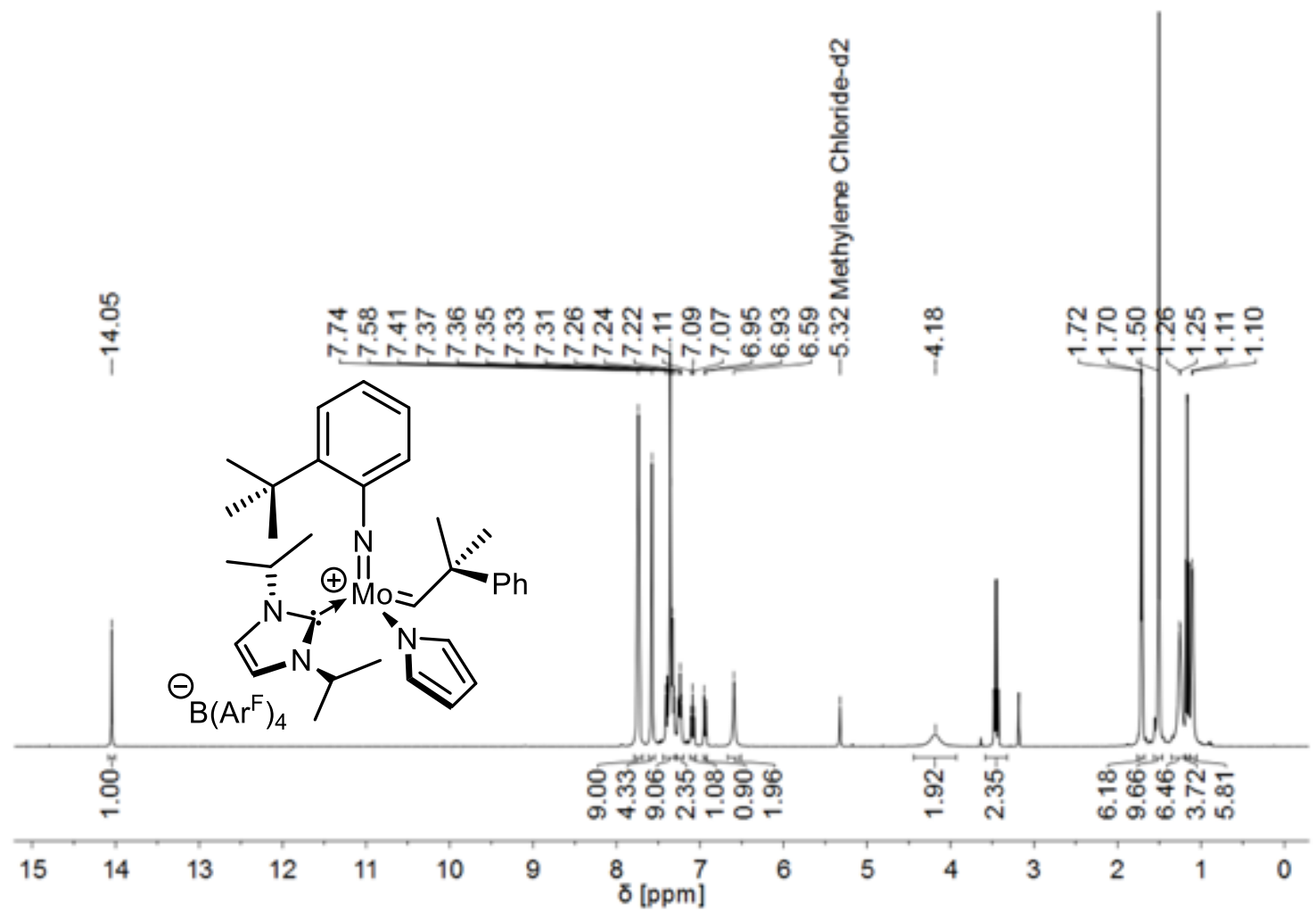

Figure S75: ${ }^{1} \mathrm{H}$ NMR spectrum $(400 \mathrm{MHz})$ of $\mathbf{I 2 4}$ in $\mathrm{CD}_{2} \mathrm{Cl}_{2}$. 


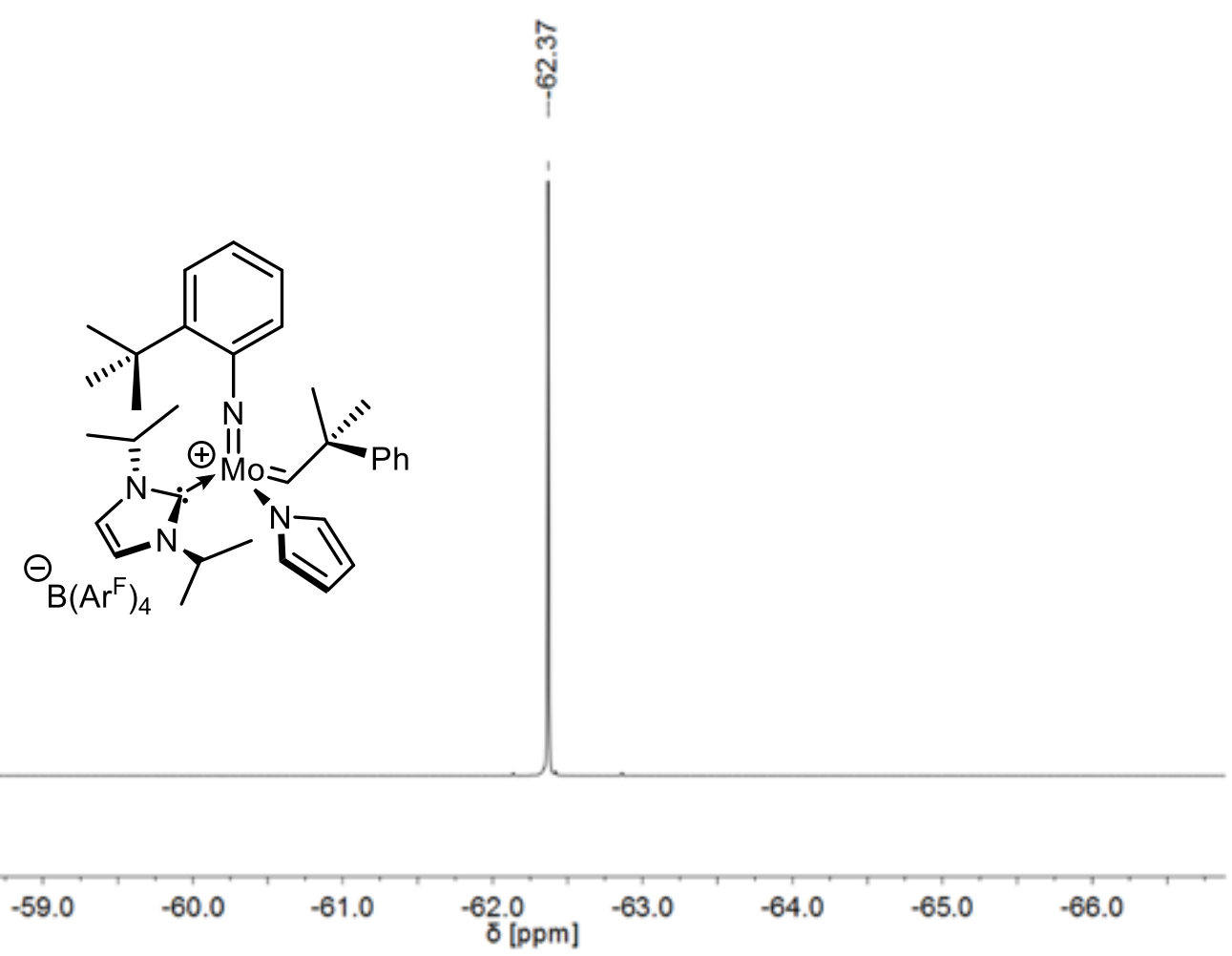

Figure S76: ${ }^{19} \mathrm{~F}$ NMR spectrum (367 MHz) of $\mathbf{I 2 4}$ in $\mathrm{CD}_{2} \mathrm{Cl}_{2}$.

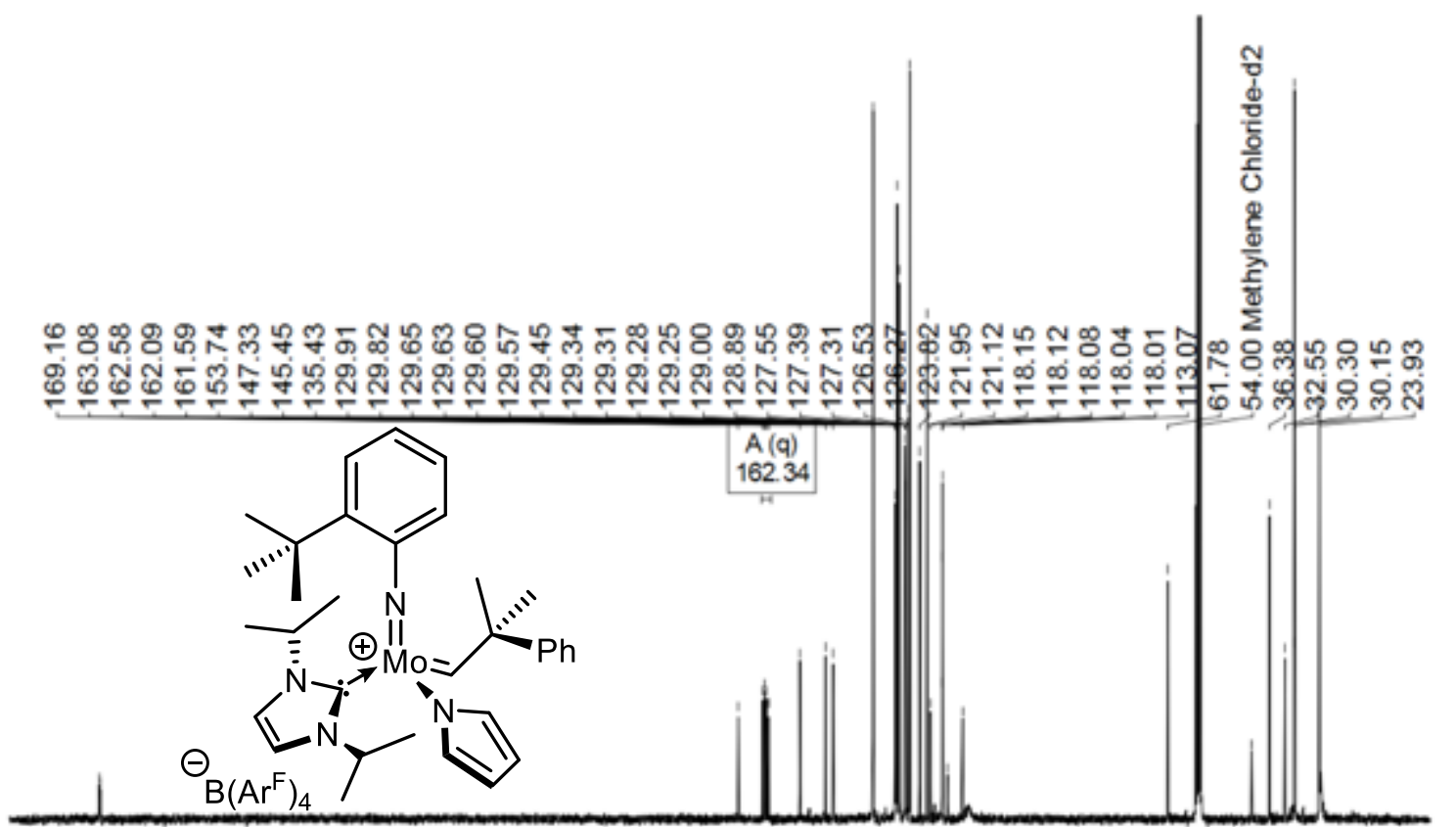

310

250

190 [ [ppm]

130

70

30

Figure S77: ${ }^{13} \mathrm{C}$ NMR spectrum (101 MHz) of $\mathbf{I 2 4}$ in $\mathrm{CD}_{2} \mathrm{Cl}_{2}$. 


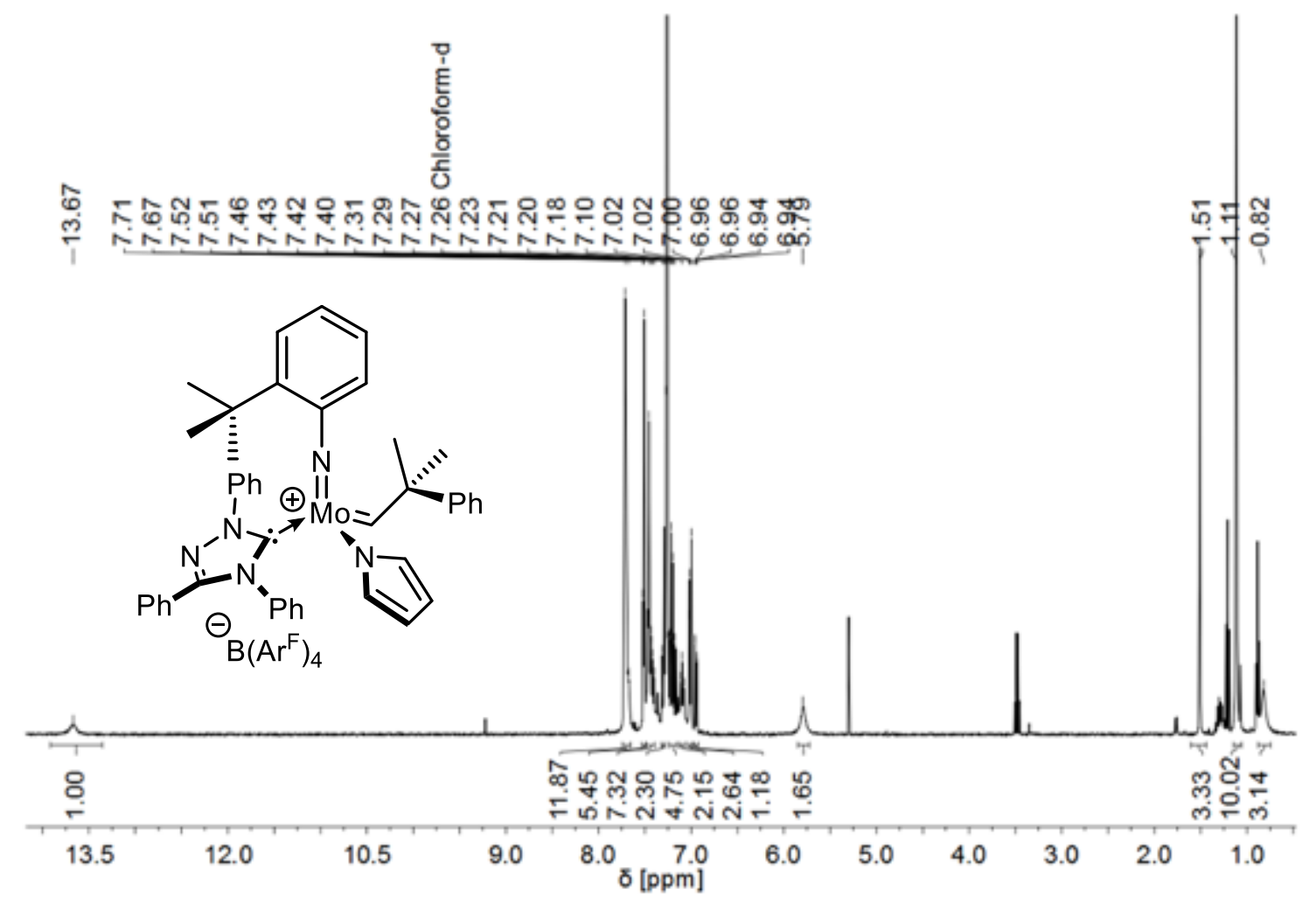

Figure S78: ${ }^{1} \mathrm{H}$ NMR spectrum $(400 \mathrm{MHz})$ of $\mathbf{I 2 6}$ in $\mathrm{CD}_{2} \mathrm{Cl}_{2}$.

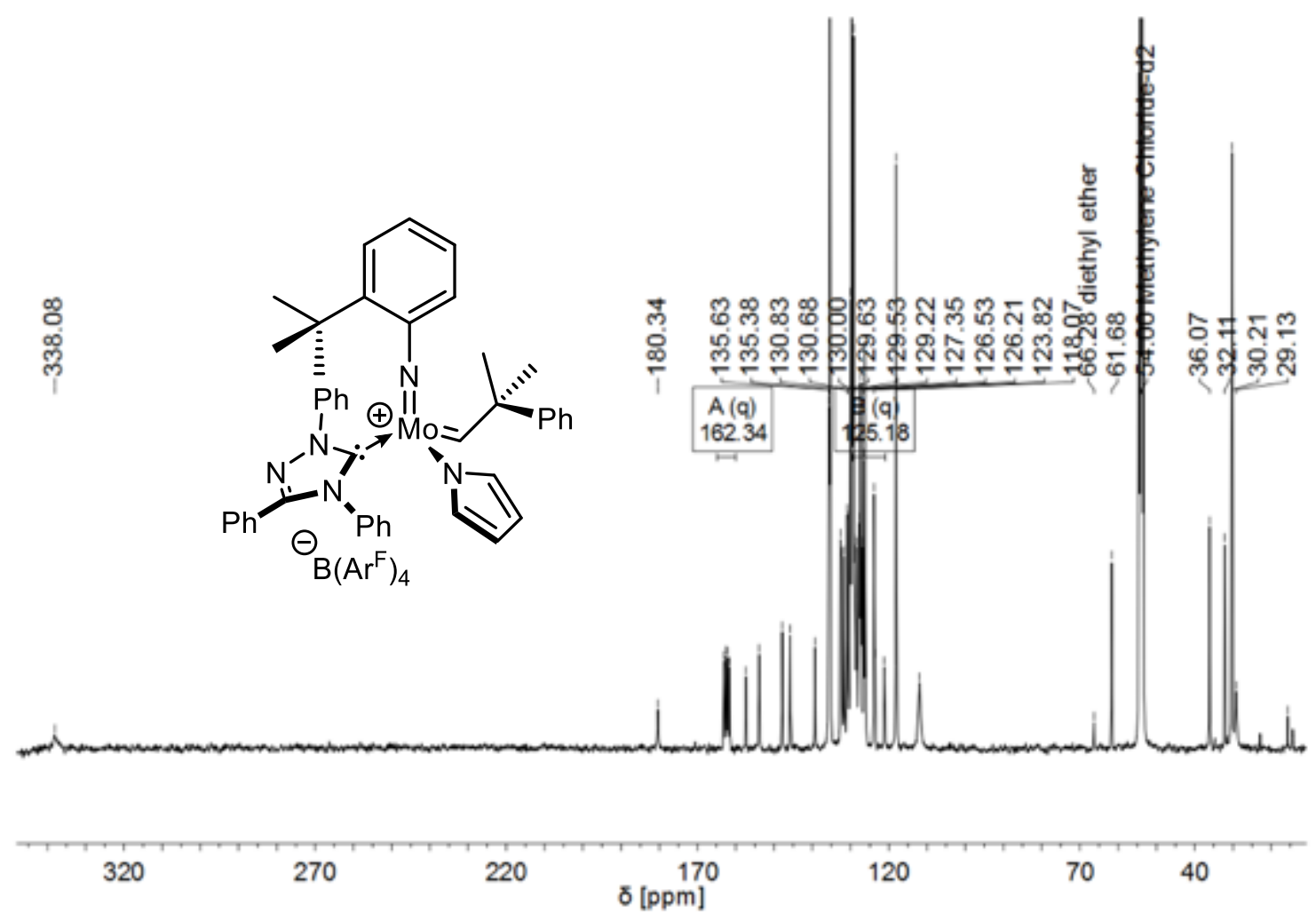

Figure S79: ${ }^{13} \mathrm{C}$ NMR spectrum $(101 \mathrm{MHz})$ of $\mathbf{I 2 6}$ in $\mathrm{CD}_{2} \mathrm{Cl}_{2}$. 


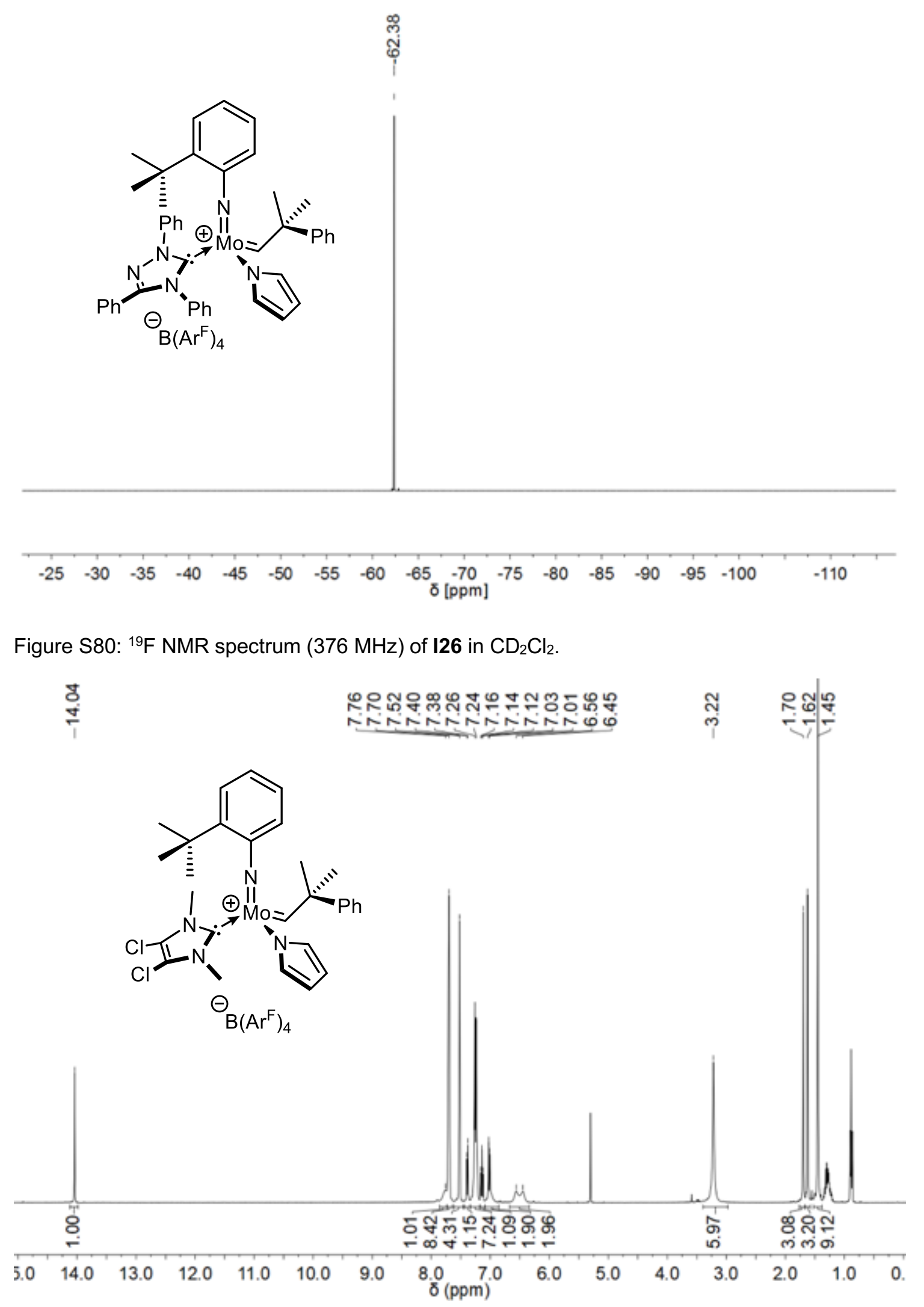

Figure S81: ${ }^{1} \mathrm{H}$ NMR spectrum $(400 \mathrm{MHz})$ of $\mathbf{I 2 7}$ in $\mathrm{CDCl}_{3}$. 
ले

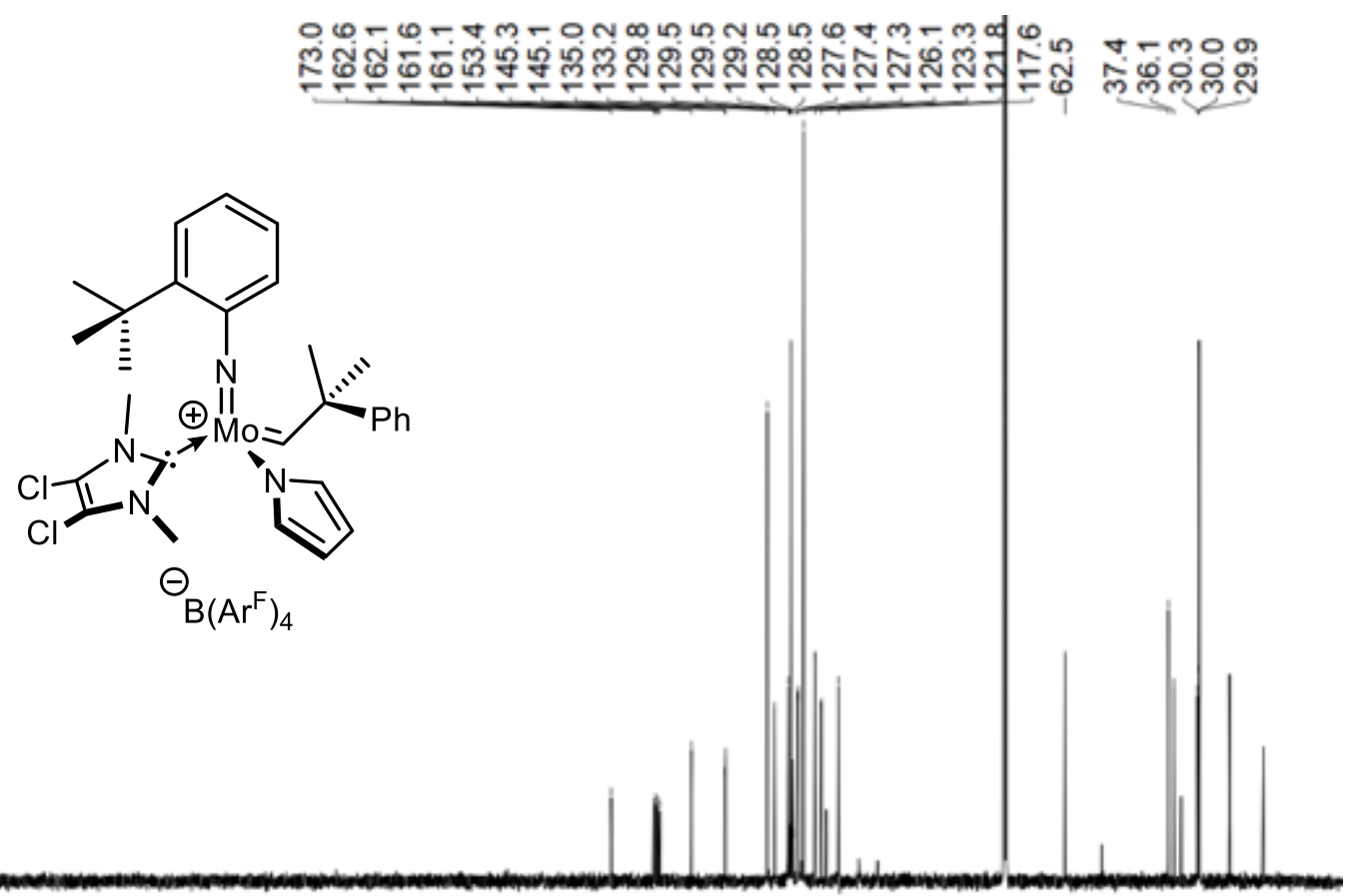

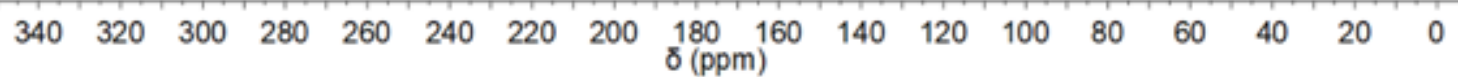

Figure S82: ${ }^{13} \mathrm{C}$ NMR spectrum (101 MHz) of $\mathbf{I 2 7}$ in $\mathrm{CD}_{2} \mathrm{Cl}_{2}$.

ミ

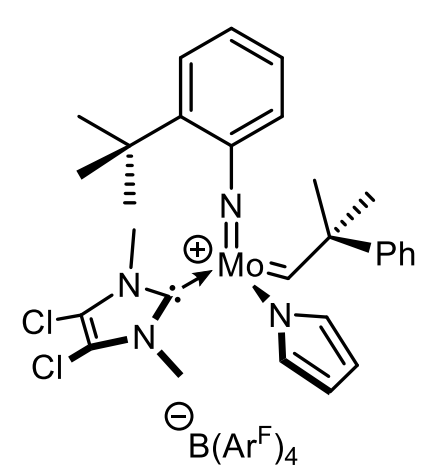

$\begin{array}{llllllllllll}10 & -10 & -30 & -50 & -70 & -90 & -110 & -130 & -150 & -170 & -190 & -210\end{array}$

Figure S83: ${ }^{19} \mathrm{~F}$ NMR spectrum $(376 \mathrm{MHz})$ of $\mathbf{I 2 7}$ in $\mathrm{CDCl}_{3}$. 


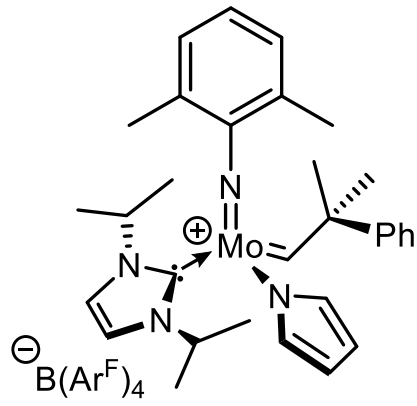

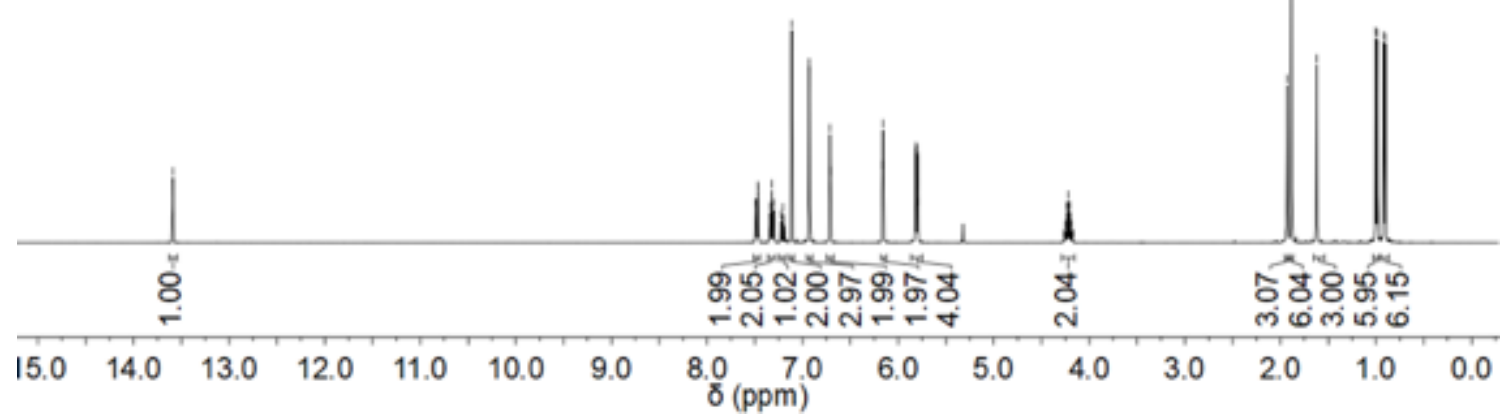

Figure S84: ${ }^{1} \mathrm{H}$ NMR spectrum $(400 \mathrm{MHz})$ of $\mathbf{I 2 2}$ in $\mathrm{CDCl}_{3}$.

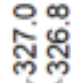

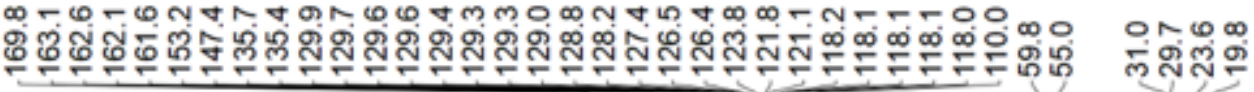

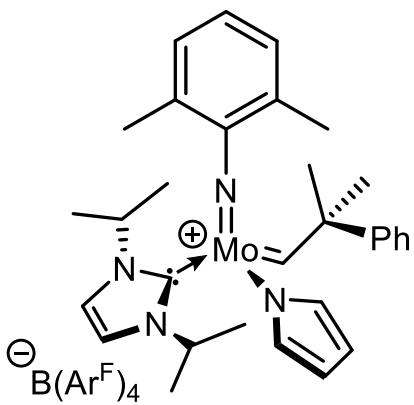

Figure S85: ${ }^{13} \mathrm{C}$ NMR spectrum (101 MHz) of $\mathbf{I 2 2}$ in $\mathrm{CD}_{2} \mathrm{Cl}_{2}$. 
₹̛̣

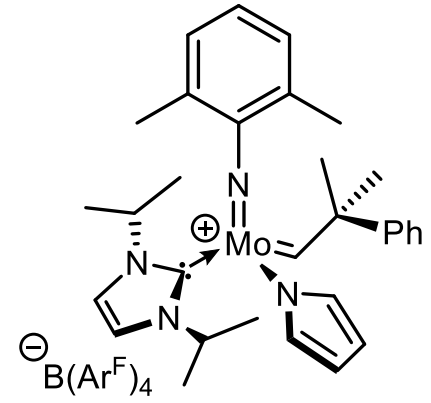

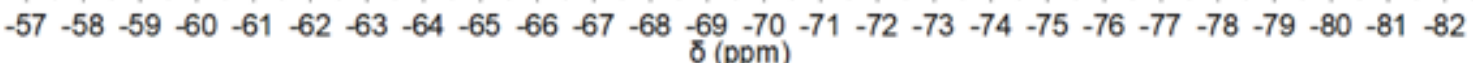

Figure S86: ${ }^{19} \mathrm{~F}$ NMR spectrum (376 MHz) of $\mathbf{I} 22$ in $\mathrm{CDCl}_{3}$

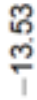

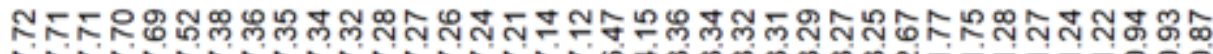

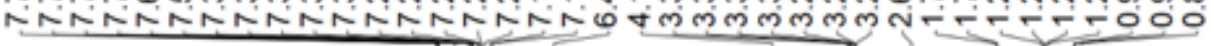

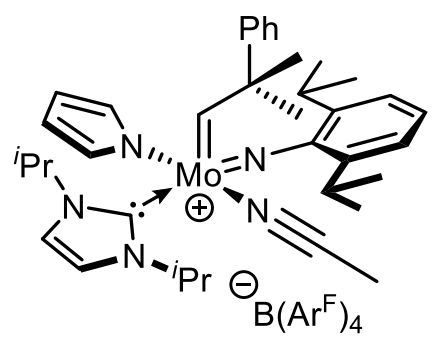
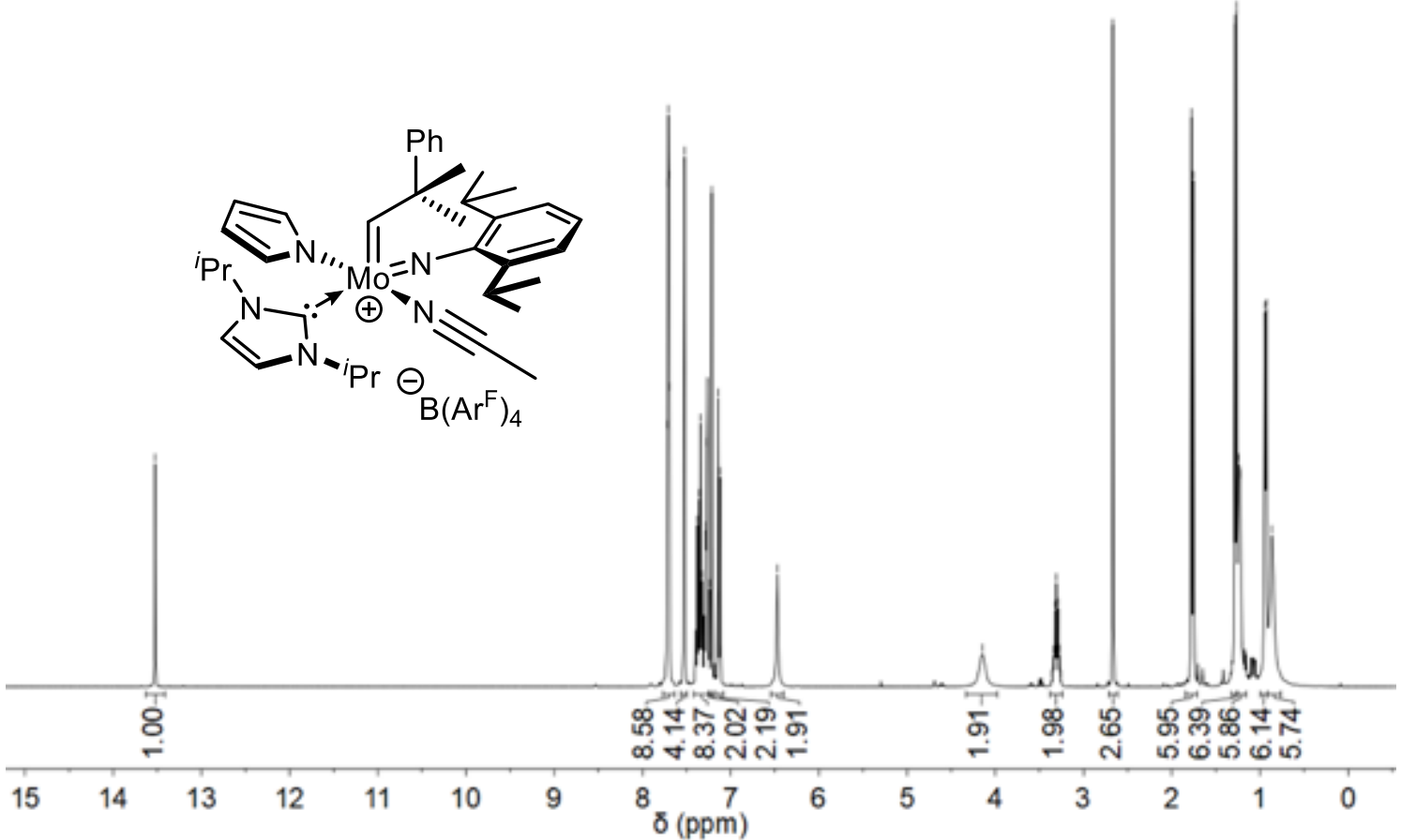

Figure S87: ${ }^{1} \mathrm{H}$ NMR spectrum (400 MHz) of $\mathrm{I} 25$ in $\mathrm{CDCl}_{3}$. 


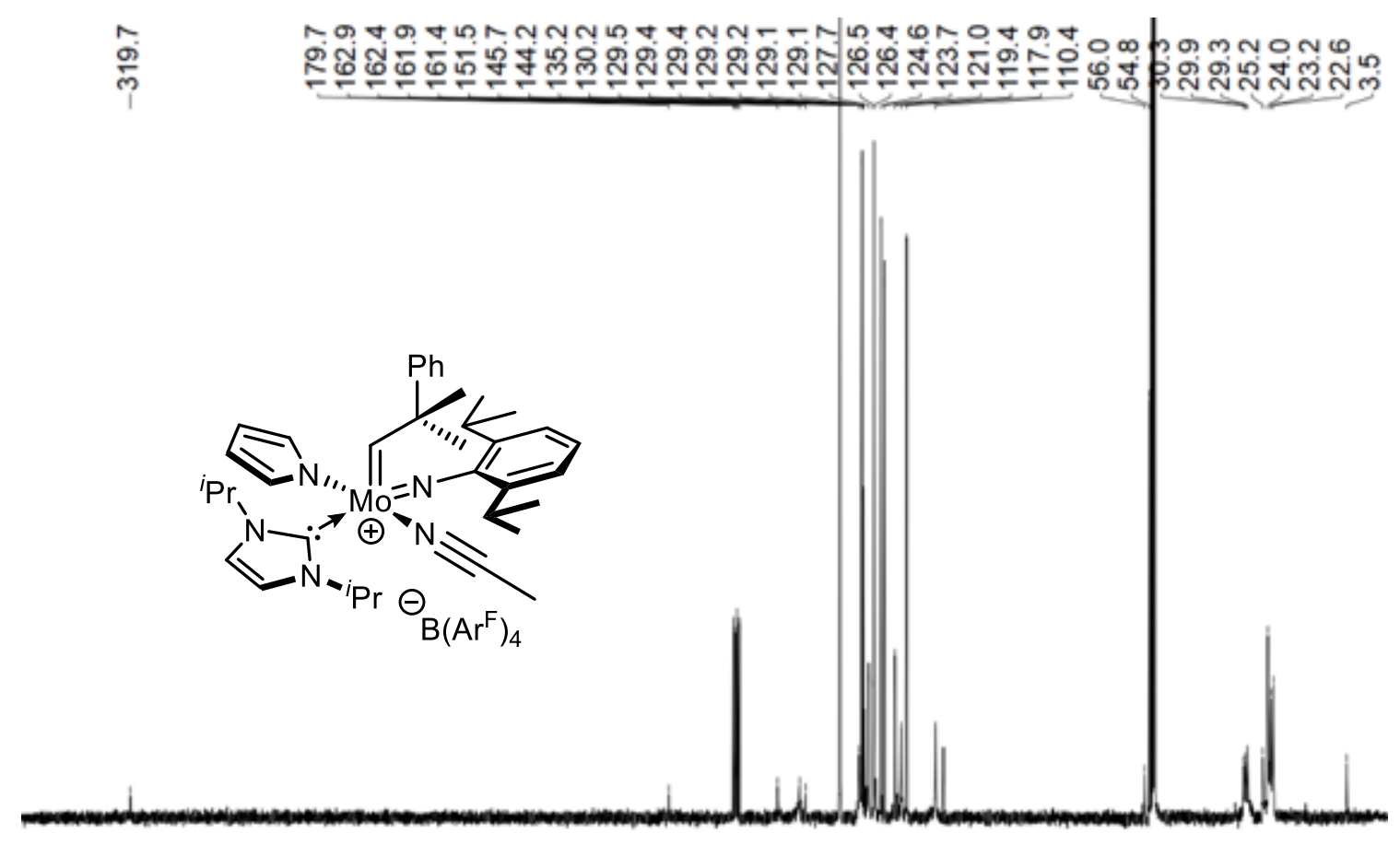

$\begin{array}{lllllllllllllllll}340 & 320 & 300 & 280 & 260 & 240 & 220 & 200 & \begin{array}{c}180 \\ \delta(\mathrm{ppm})\end{array} & 140 & 120 & 100 & 80 & 60 & 40 & 20 & 0\end{array}$

Figure S88: ${ }^{13} \mathrm{C}$ NMR spectrum $(101 \mathrm{MHz})$ of $\mathbf{I 2 5}$ in $\mathrm{CDCl}_{3}$.

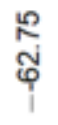

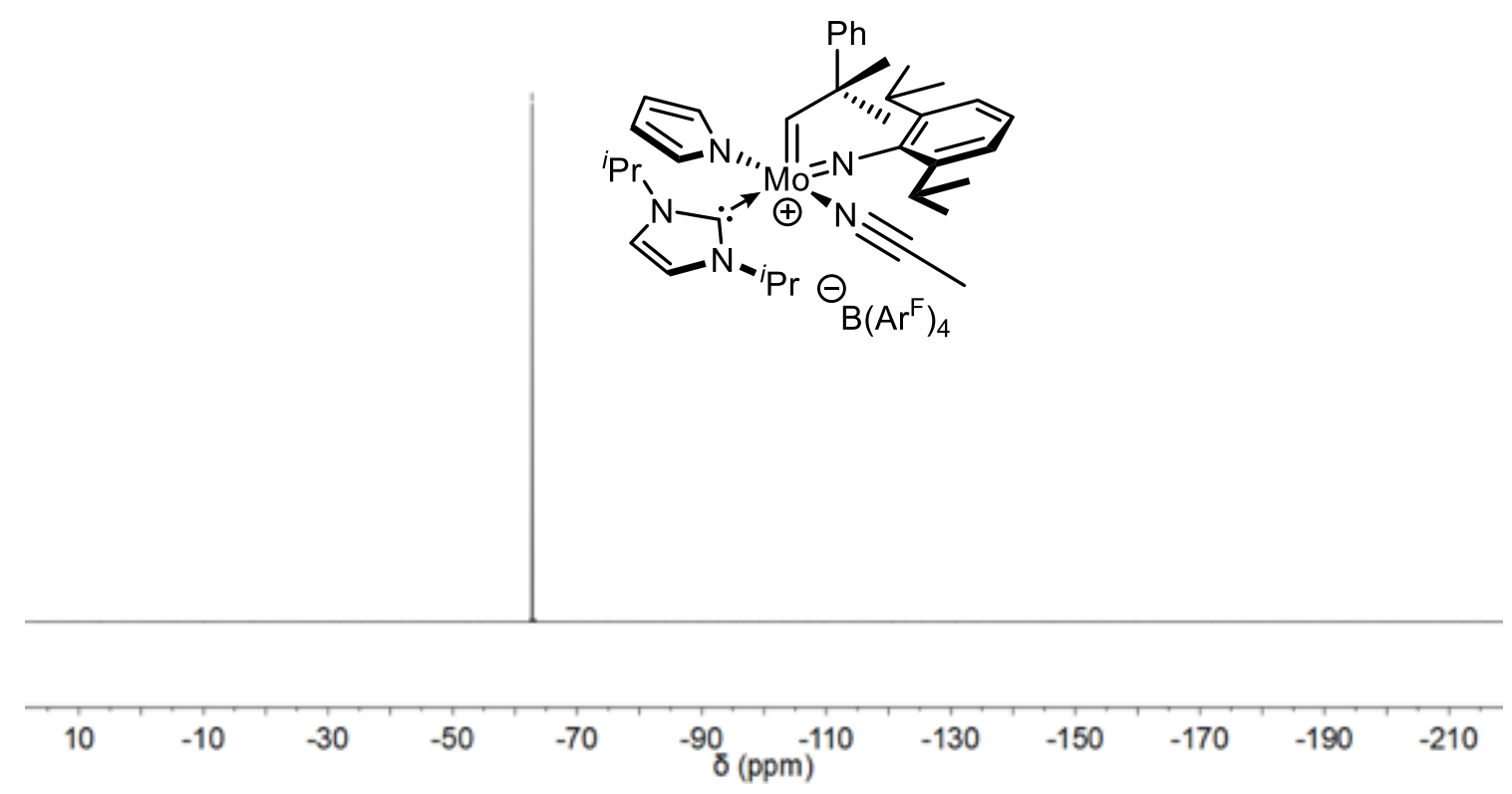

Figure S89: ${ }^{19} \mathrm{~F}$ NMR spectrum $(376 \mathrm{MHz})$ of $\mathbf{I} 25$ in $\mathrm{CDCl}_{3}$. 


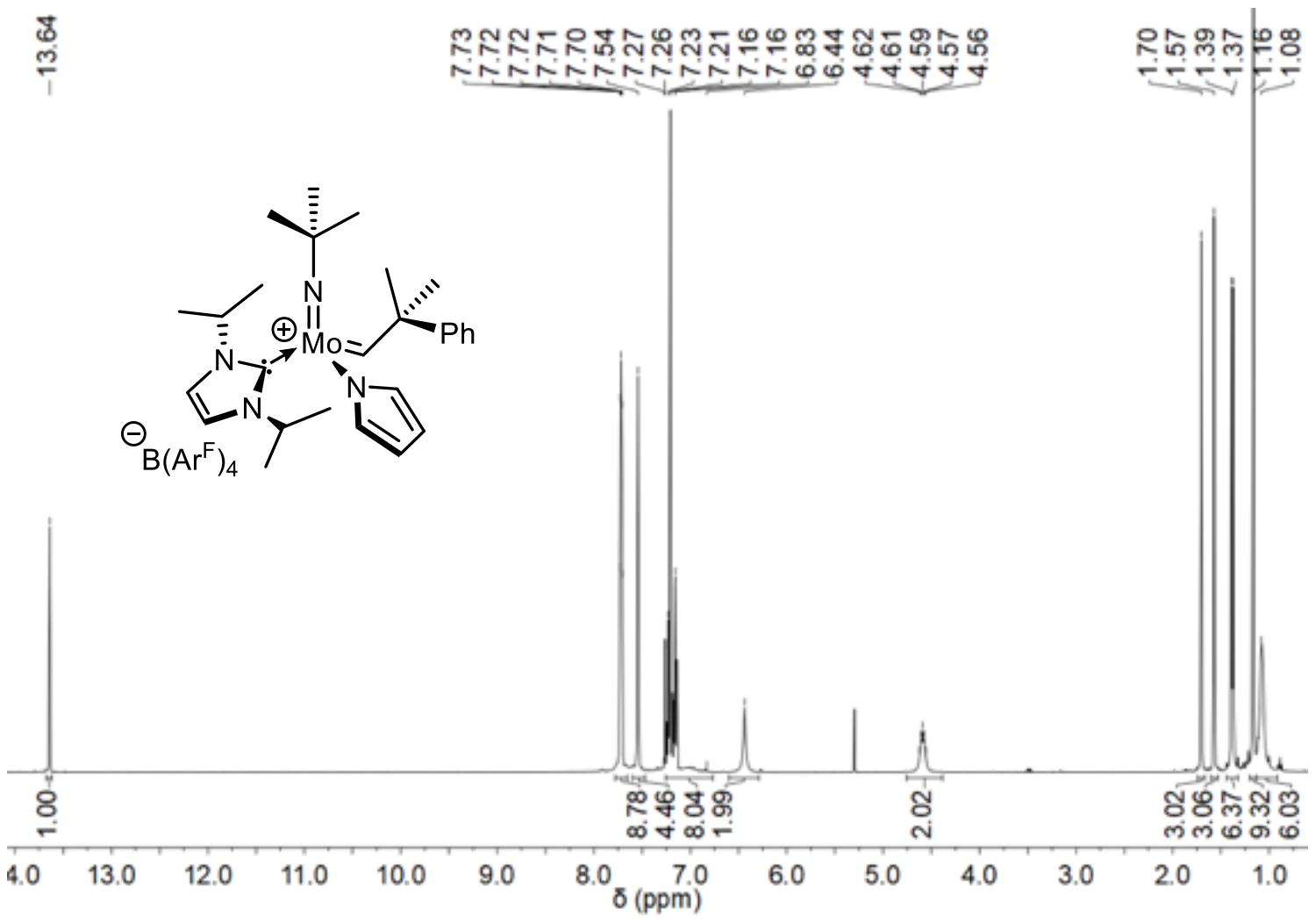

Figure S90: ${ }^{1} \mathrm{H}$ NMR spectrum $(400 \mathrm{MHz})$ of $\mathbf{I} 23$ in $\mathrm{CDCl}_{3}$.

$\stackrel{\oplus}{\text { ก }}$

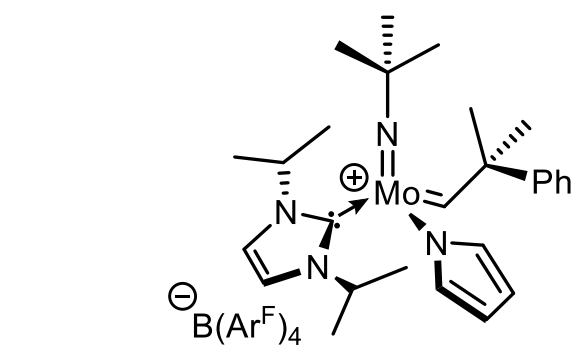

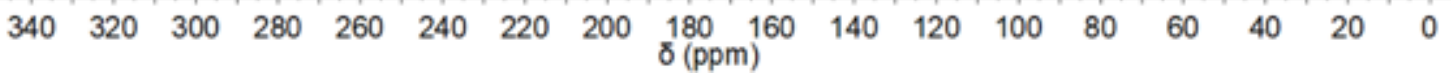

Figure S91: ${ }^{13} \mathrm{C}$ NMR spectrum $(101 \mathrm{MHz})$ of $\mathbf{I 2 3}$ in $\mathrm{CDCl}_{3}$. 


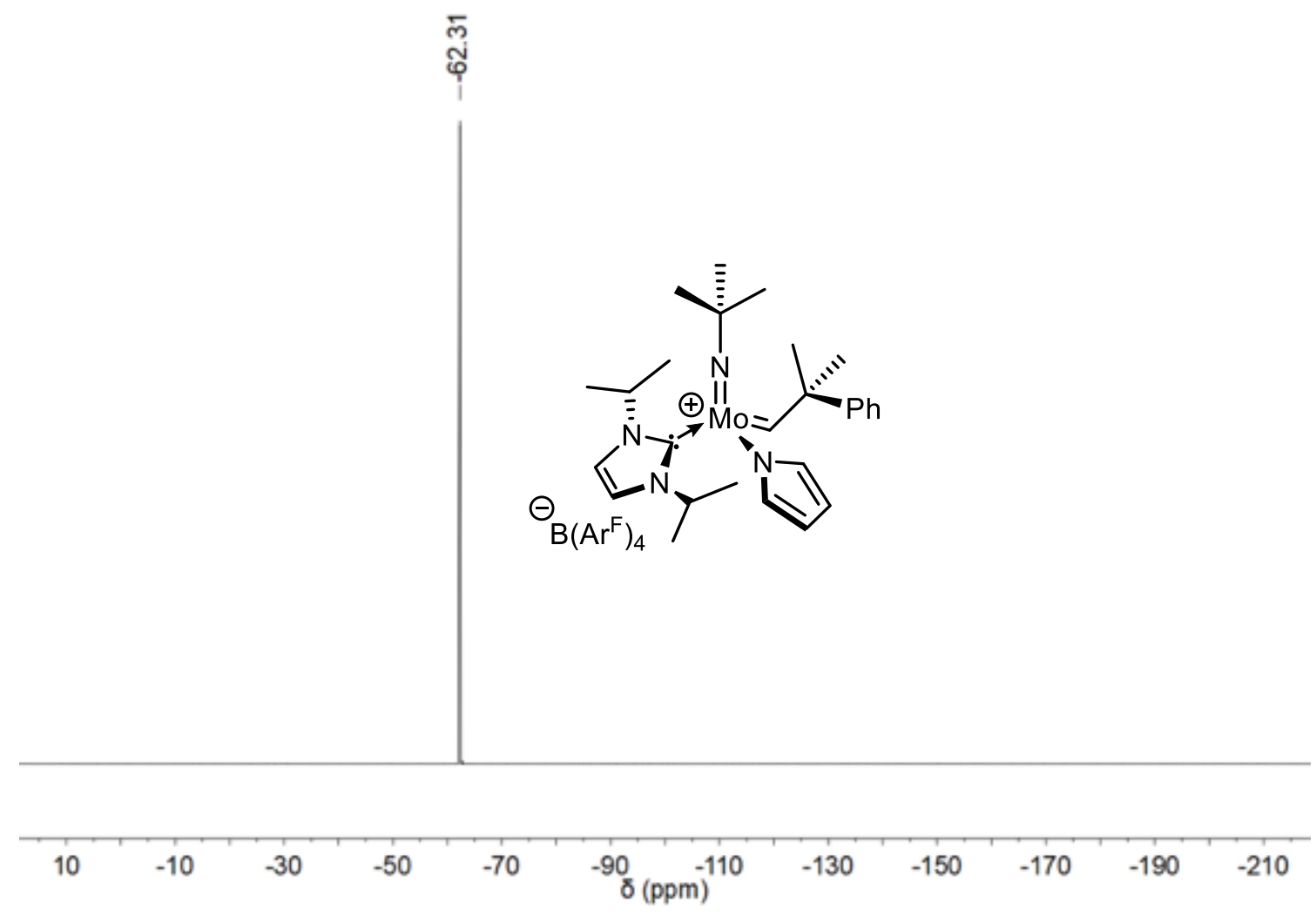

Figure S92: ${ }^{19} \mathrm{~F}$ NMR spectrum $(376 \mathrm{MHz})$ of $\mathbf{I 2 3}$ in $\mathrm{CDCl}_{3}$.

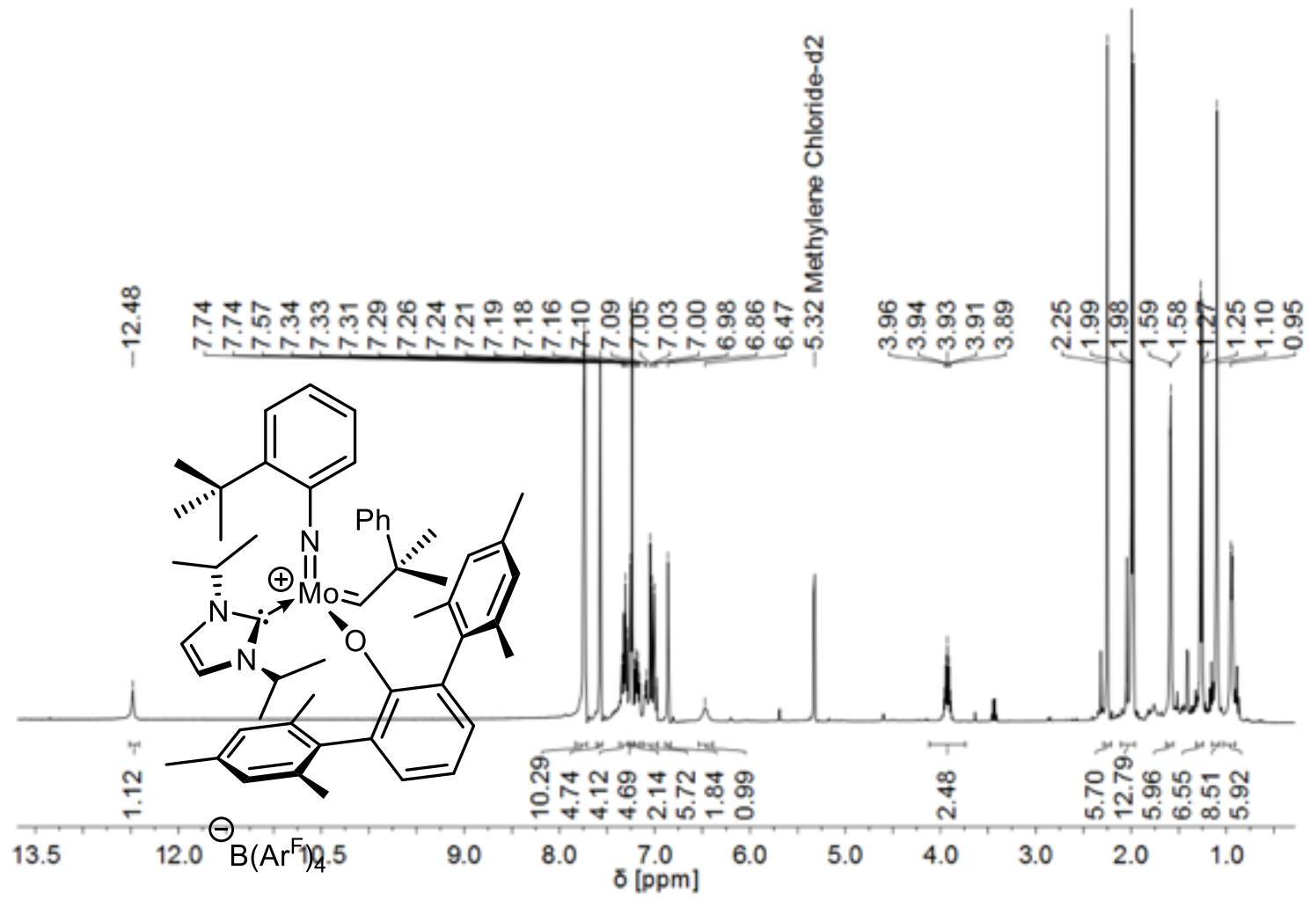

Figure S93: ${ }^{1} \mathrm{H}$ NMR spectrum $(400 \mathrm{MHz})$ of $\mathbf{I 2 8}$ in $\mathrm{CD}_{2} \mathrm{Cl}_{2}$. 


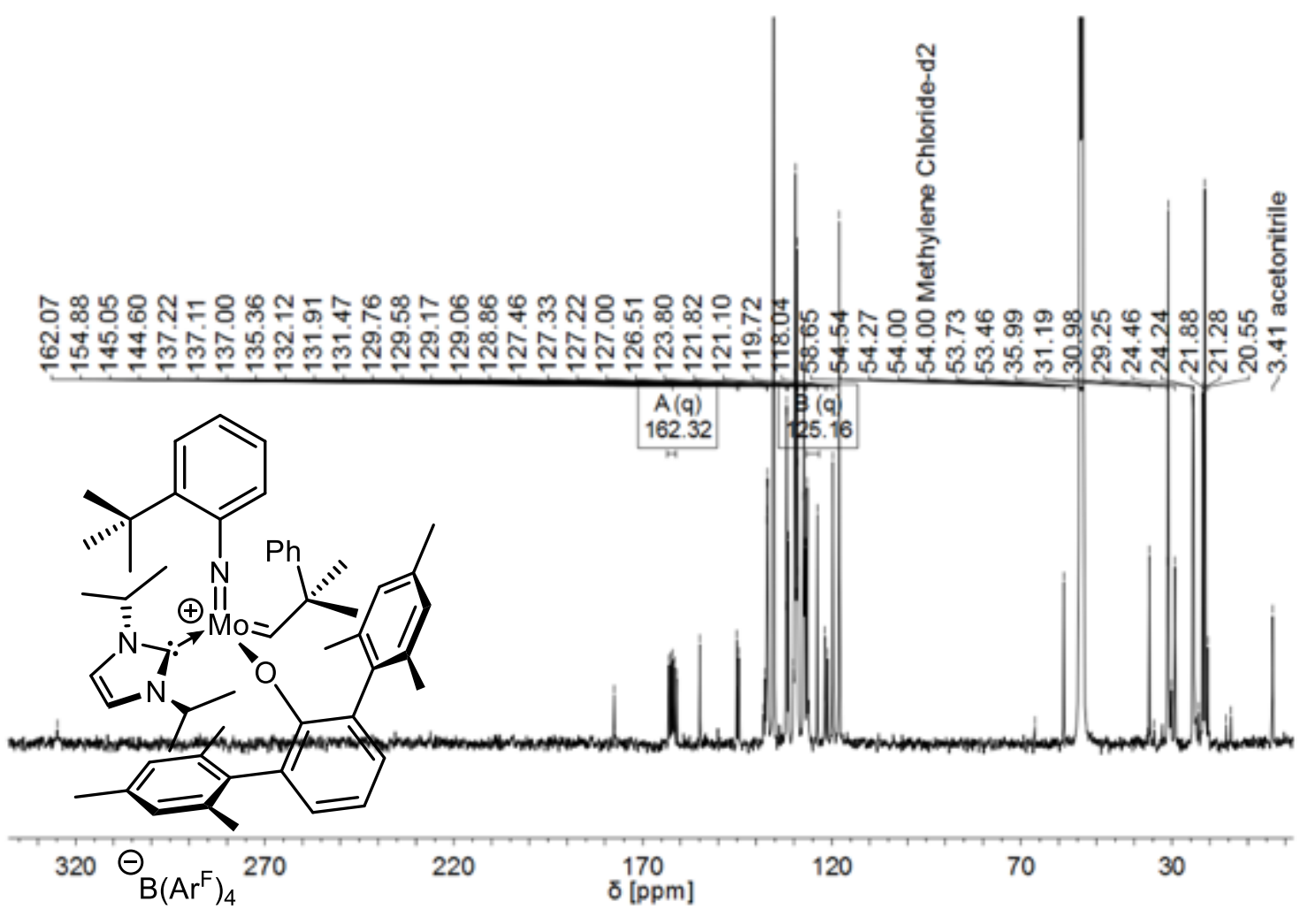

Figure S94: ${ }^{13} \mathrm{C}$ NMR spectrum $(101 \mathrm{MHz})$ of $\mathbf{I 2 8}$ in $\mathrm{CD}_{2} \mathrm{Cl}_{2}$.

$\stackrel{0}{0}$

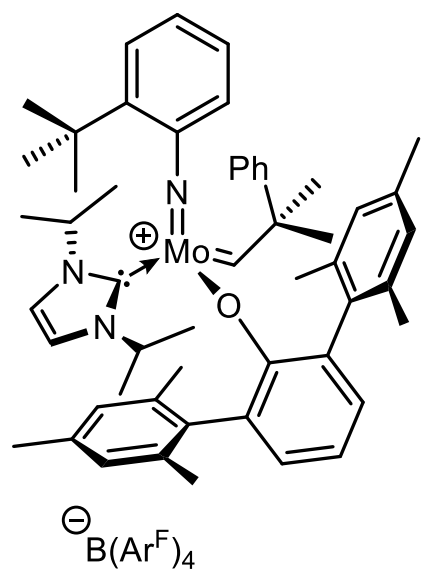

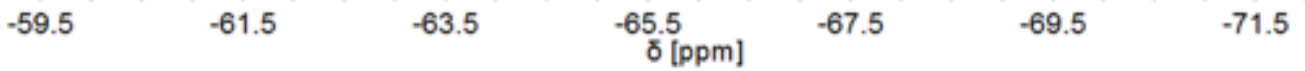

Figure S95: ${ }^{19} \mathrm{~F}$ NMR spectrum (376 MHz) of $\mathbf{I 2 8}$ in $\mathrm{CD}_{2} \mathrm{Cl}_{2}$. 


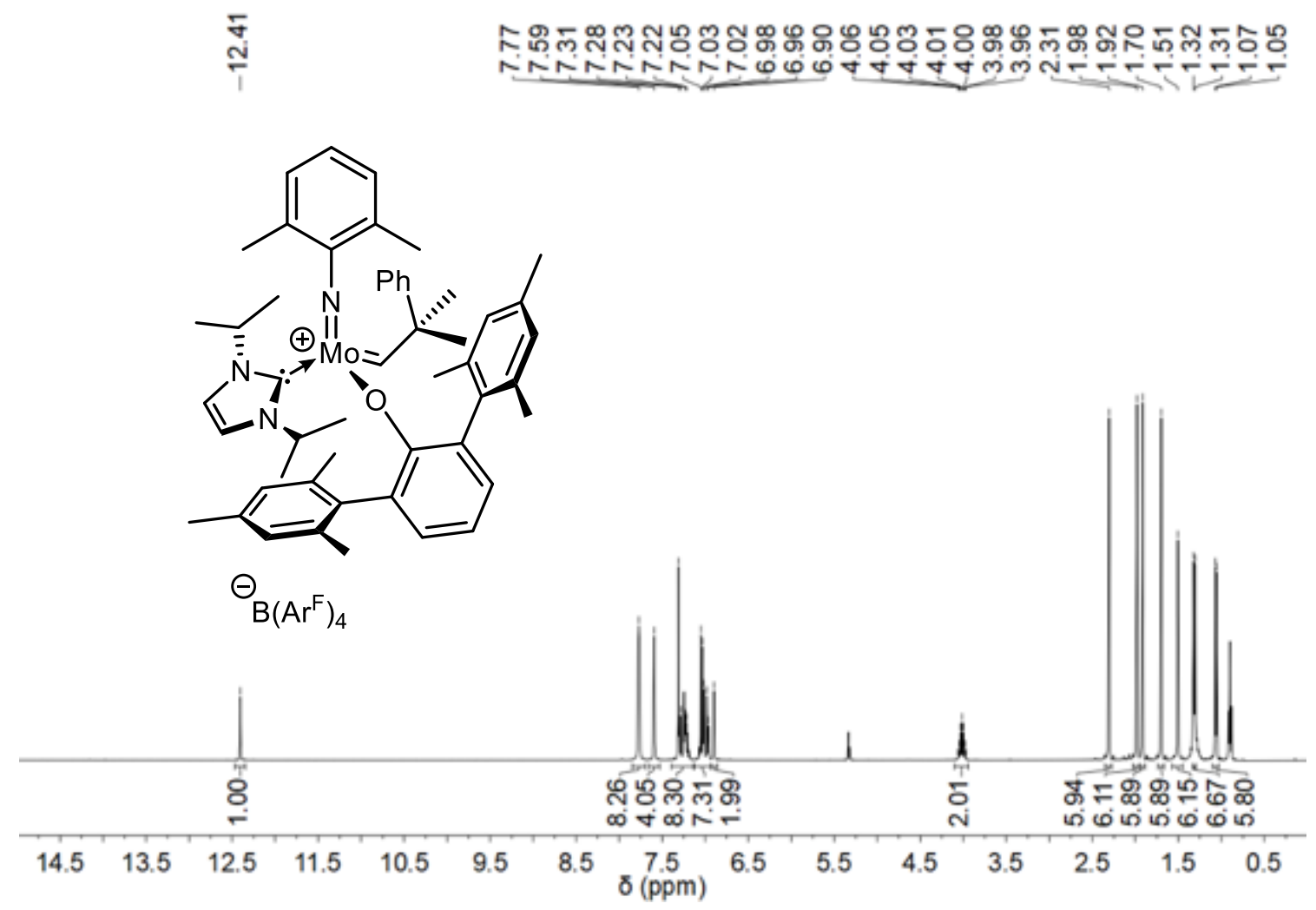

Figure S96: ${ }^{1} \mathrm{H}$ NMR spectrum $\left(400 \mathrm{MHz}\right.$ ) of $\mathbf{I 2 9}$ in $\mathrm{CD}_{2} \mathrm{Cl}_{2}$.

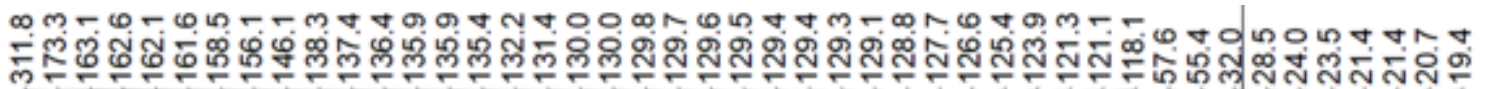

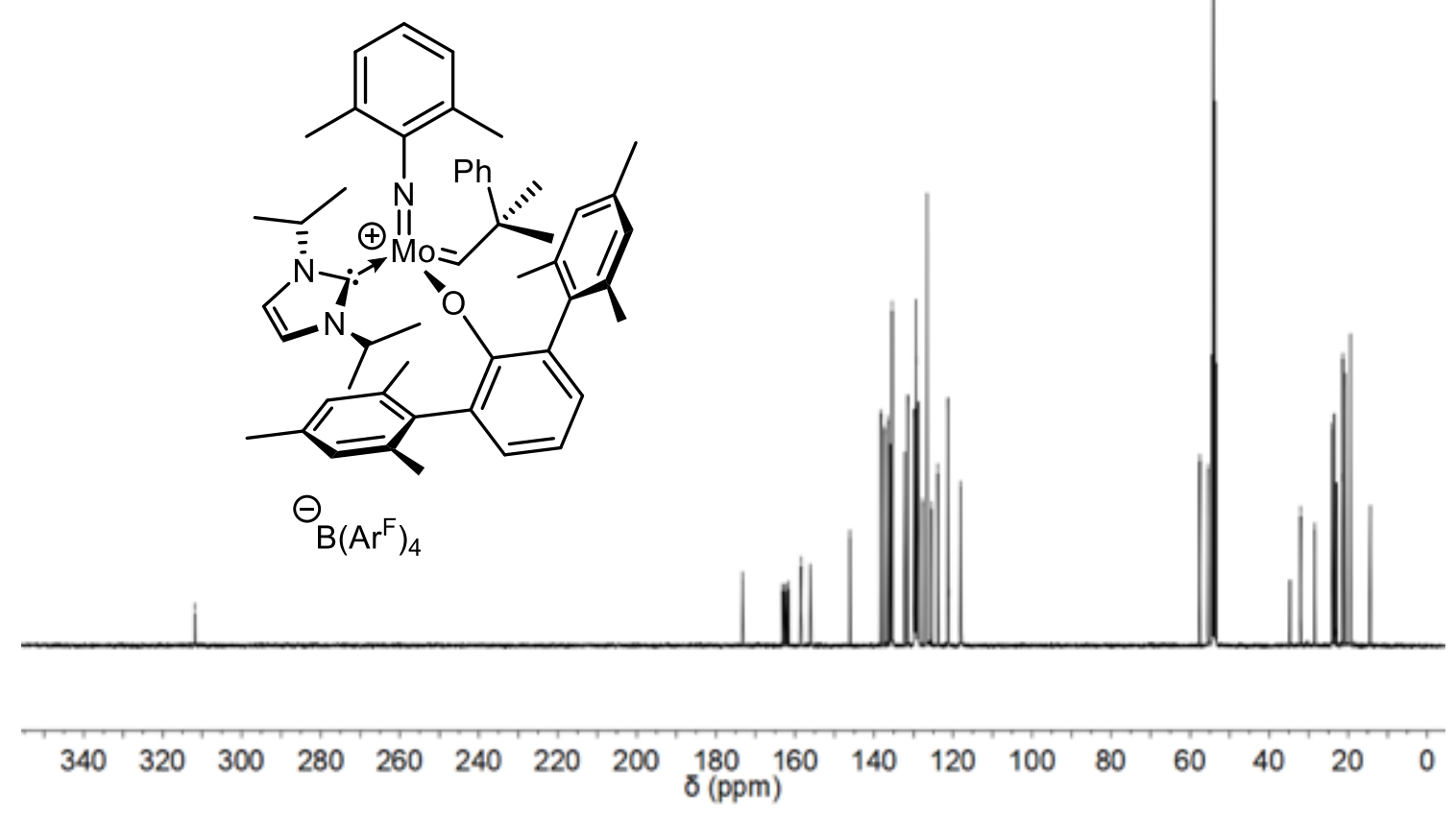

Figure S97: ${ }^{13} \mathrm{C}$ NMR spectrum (101 MHz) of $\mathbf{I 2 9}$ in $\mathrm{CD}_{2} \mathrm{Cl}_{2}$. 


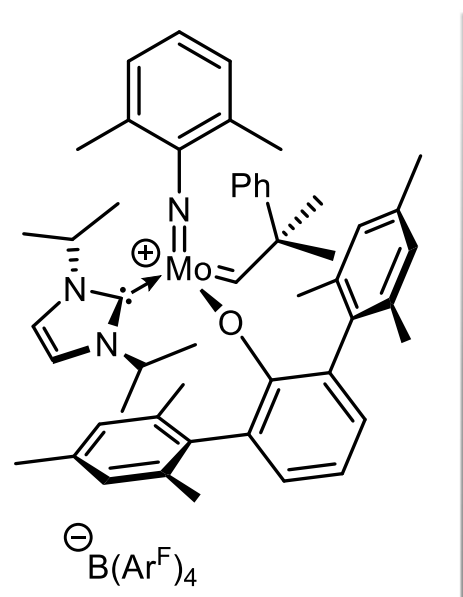

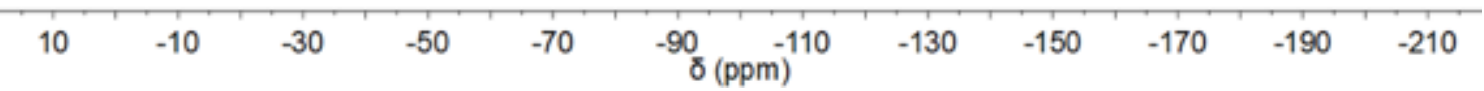

Figure S98: ${ }^{19} \mathrm{~F}$ NMR spectrum (376 MHz) of $\mathbf{I 2 9}$ in $\mathrm{CD}_{2} \mathrm{Cl}_{2}$.

\section{Polymers}

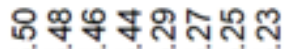

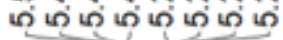

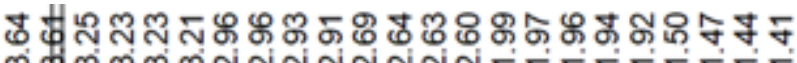 \\ लंग लм}

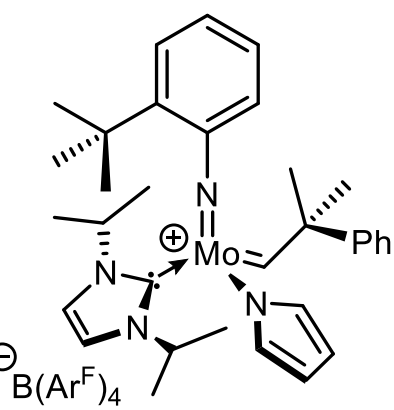<smiles>COC(=O)[C@H]1C2C=CC(C2)[C@H]1C(=O)OC</smiles>

$\Theta_{\mathrm{B}(\mathrm{ArF})_{4}}$
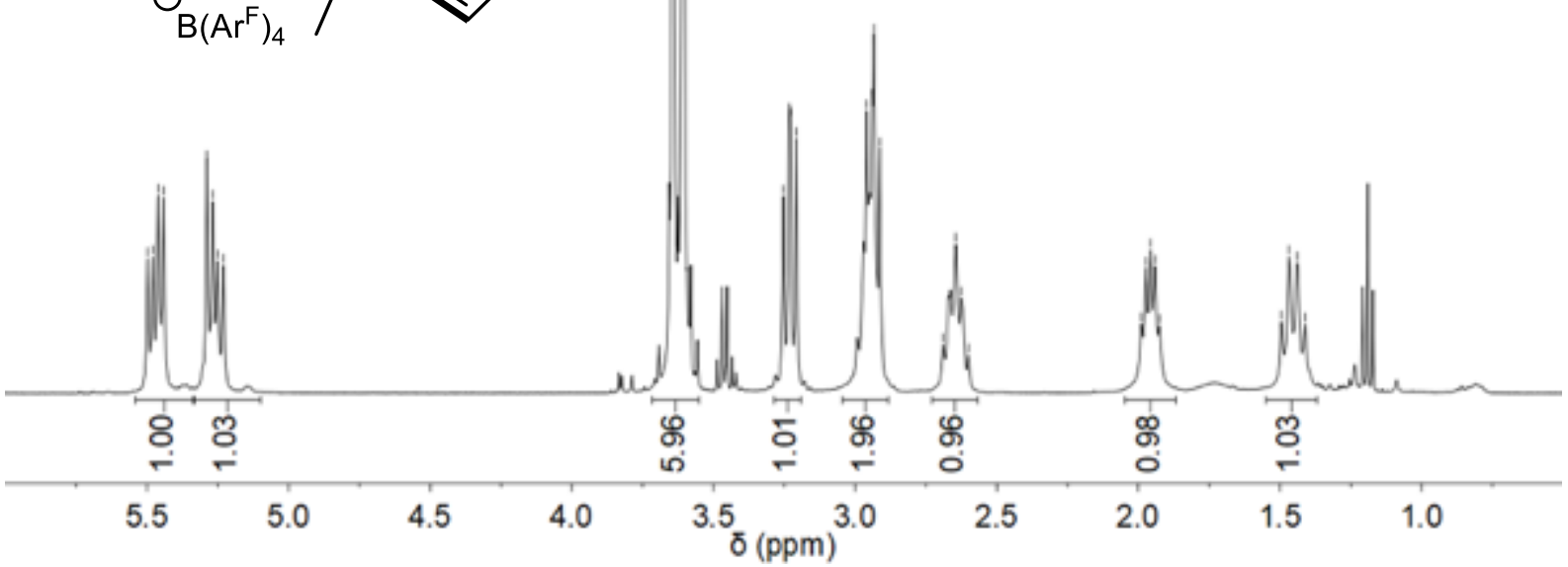

Figure S99: ${ }^{1} \mathrm{H}$ NMR spectrum $(400 \mathrm{MHz})$ of poly(M1)//24 in $\mathrm{CDCl}_{3}$. 


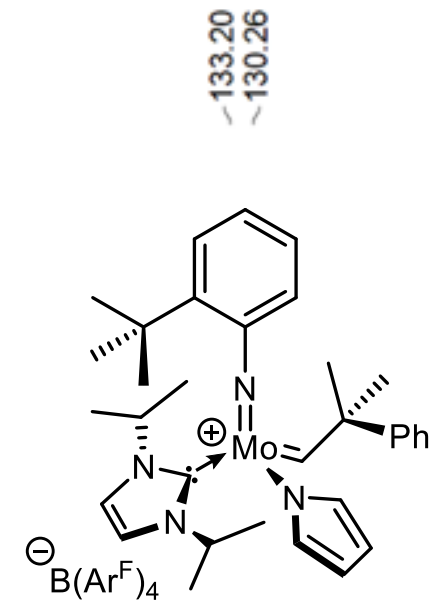<smiles>COC(=O)[C@H]1C2C=CC(C2)[C@H]1C(=O)OC</smiles>

$\begin{array}{lllllllllllllllllllll}10 & 190 & 180 & 170 & 160 & 150 & 140 & 130 & 120 & 110 \underset{\delta(\mathrm{ppm})}{100} & 90 & 80 & 70 & 60 & 50 & 40 & 30 & 20 & 10 & 6\end{array}$

Figure S100: ${ }^{13} \mathrm{C}$ NMR spectrum $(400 \mathrm{MHz})$ of poly(M1)//24 in $\mathrm{CDCl}_{3}$.

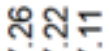

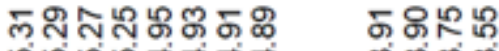
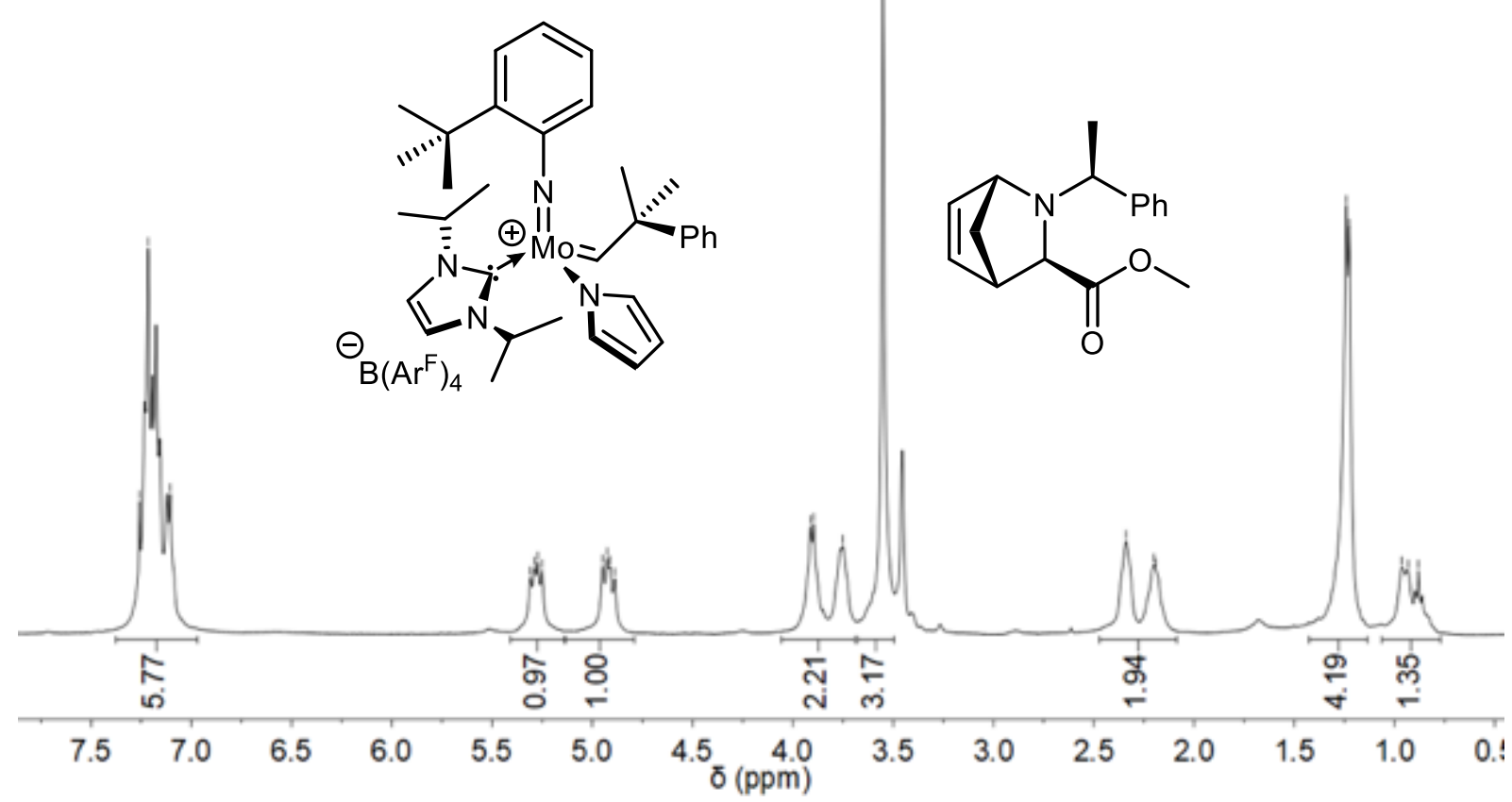

Figure S101: ${ }^{1} \mathrm{H}$ NMR spectrum $(400 \mathrm{MHz})$ of poly(M3)//24 in $\mathrm{CDCl}_{3}$. 


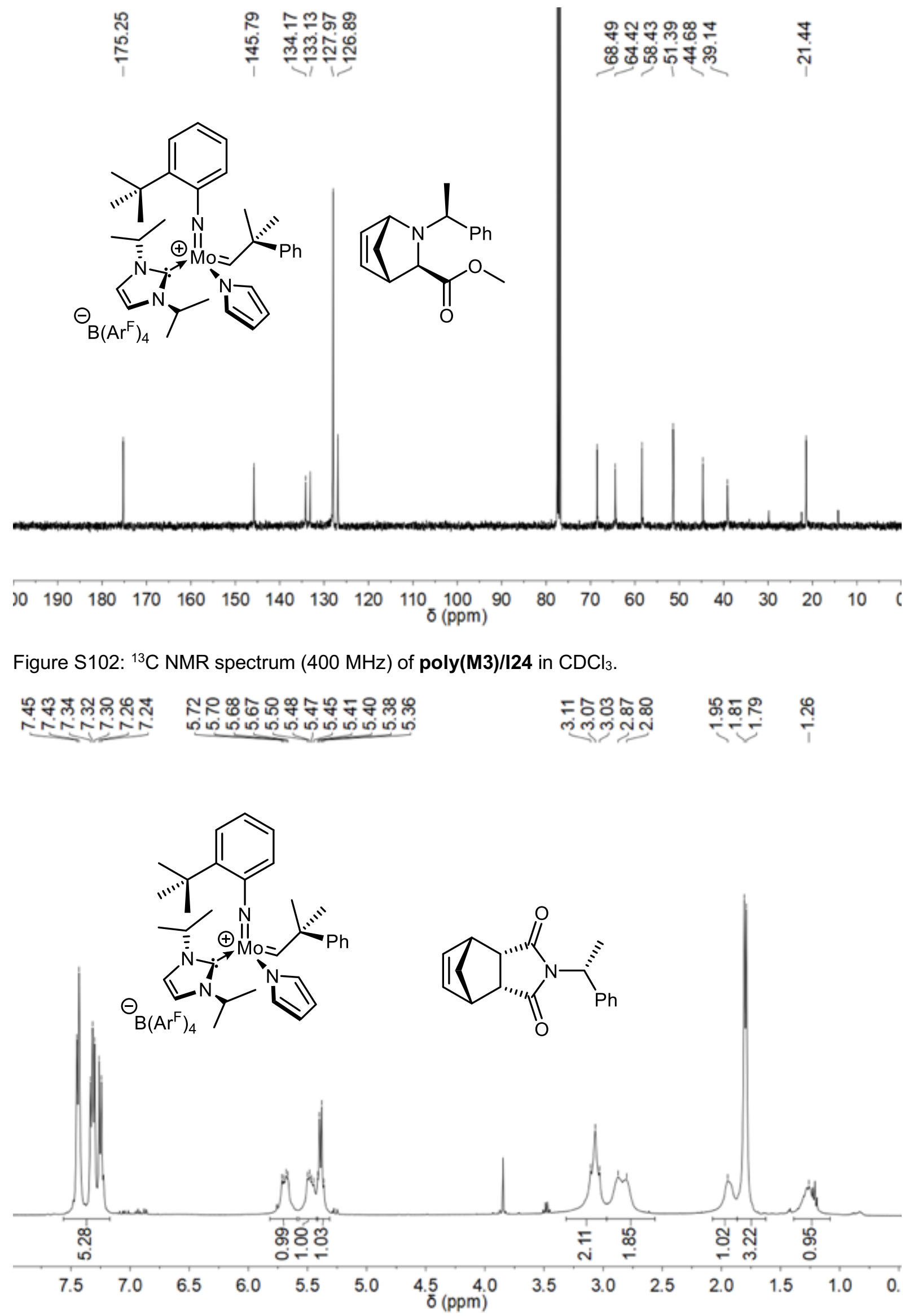

Figure S103: ${ }^{1} \mathrm{H}$ NMR spectrum $(400 \mathrm{MHz})$ of poly(M4)//24 in $\mathrm{CDCl}_{3}$. 

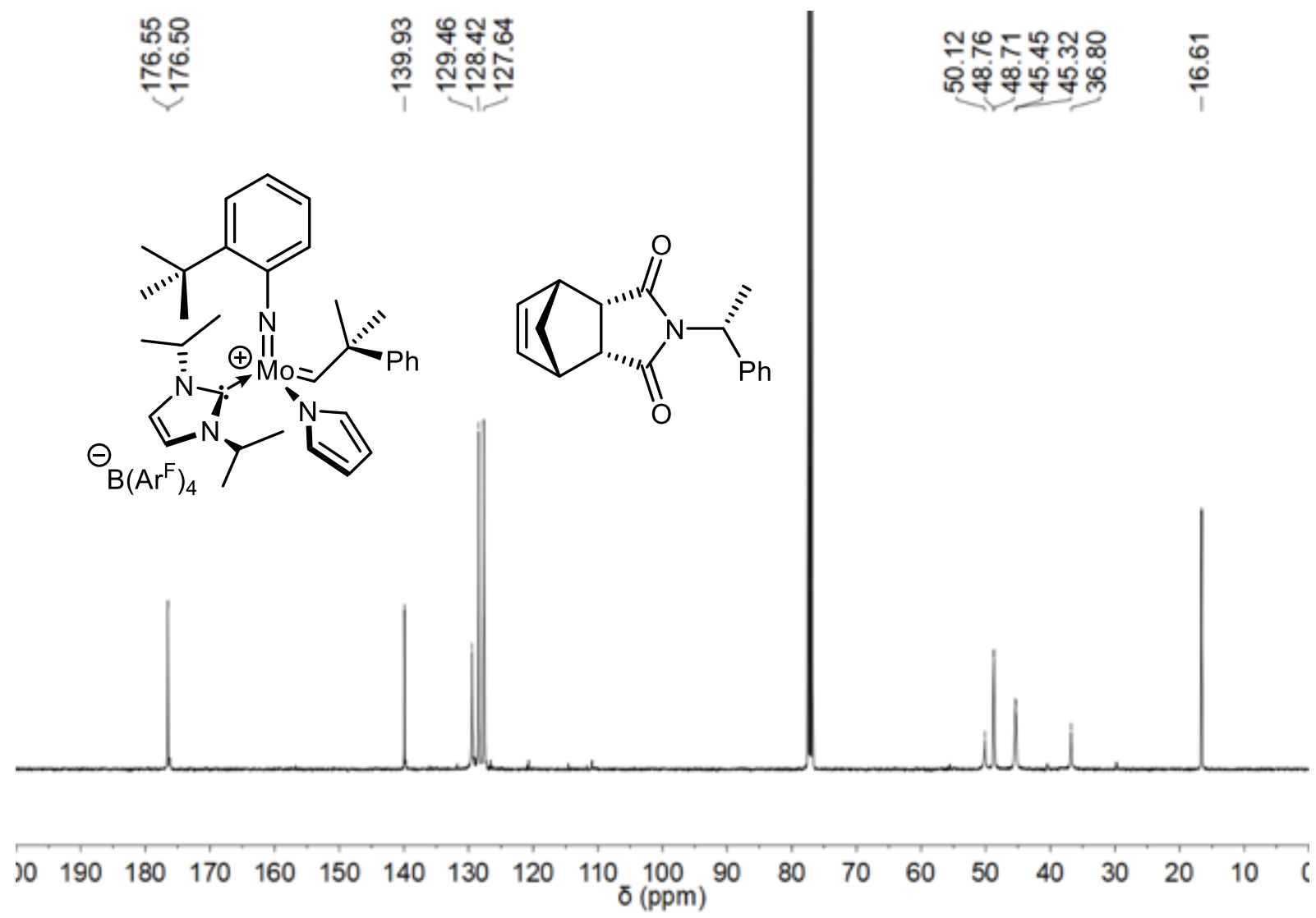

Figure S104: ${ }^{13} \mathrm{C}$ NMR spectrum (400 MHz) of poly(M4)//24 in $\mathrm{CDCl}_{3}$.

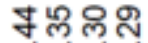

NNNN

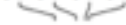

रब्लू్లు

เก่เกตร
సิ

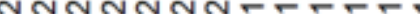

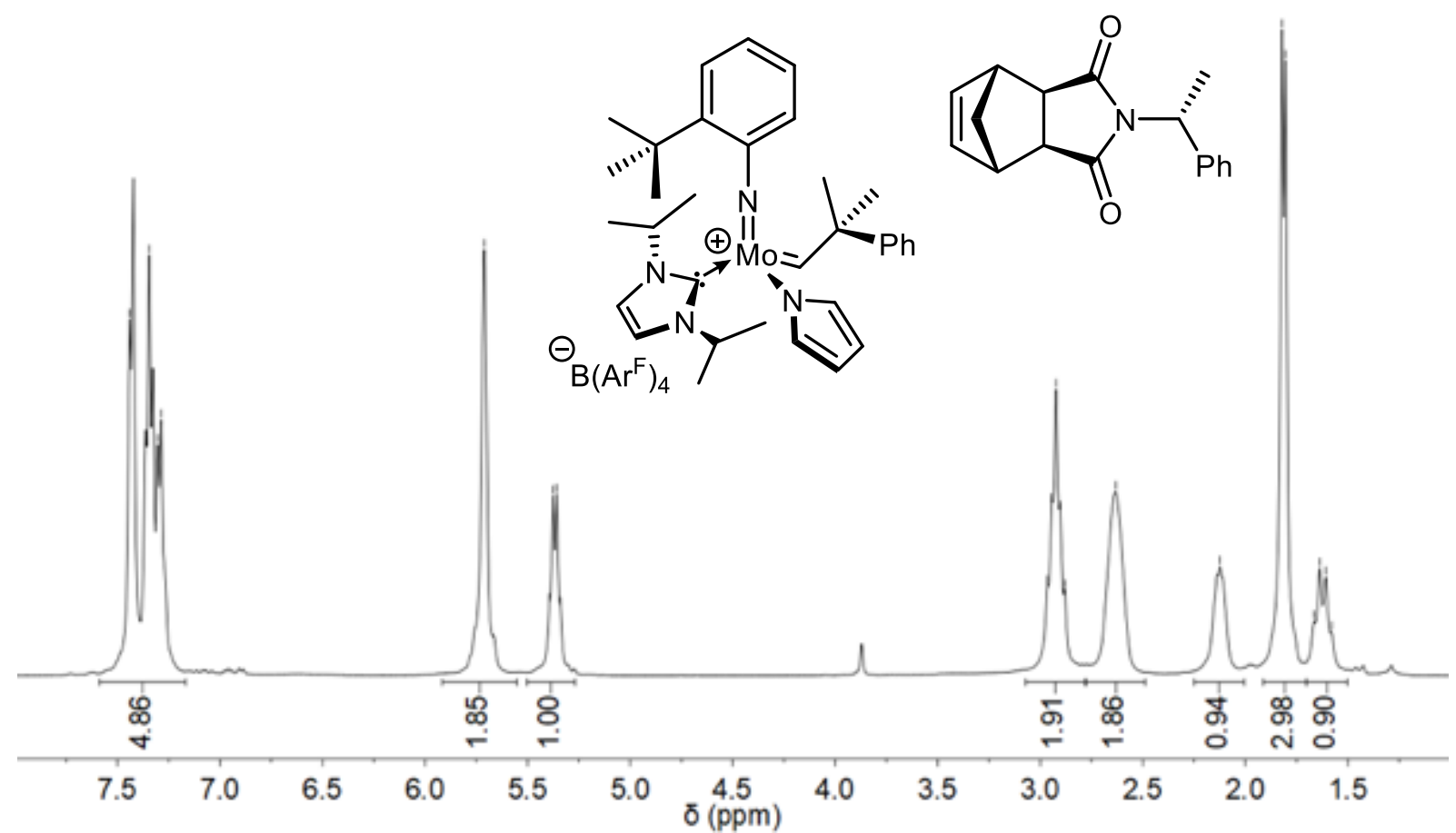

Figure S105: ${ }^{1} \mathrm{H}$ NMR spectrum $(400 \mathrm{MHz})$ of poly(M5)//24 in $\mathrm{CDCl}_{3}$. 

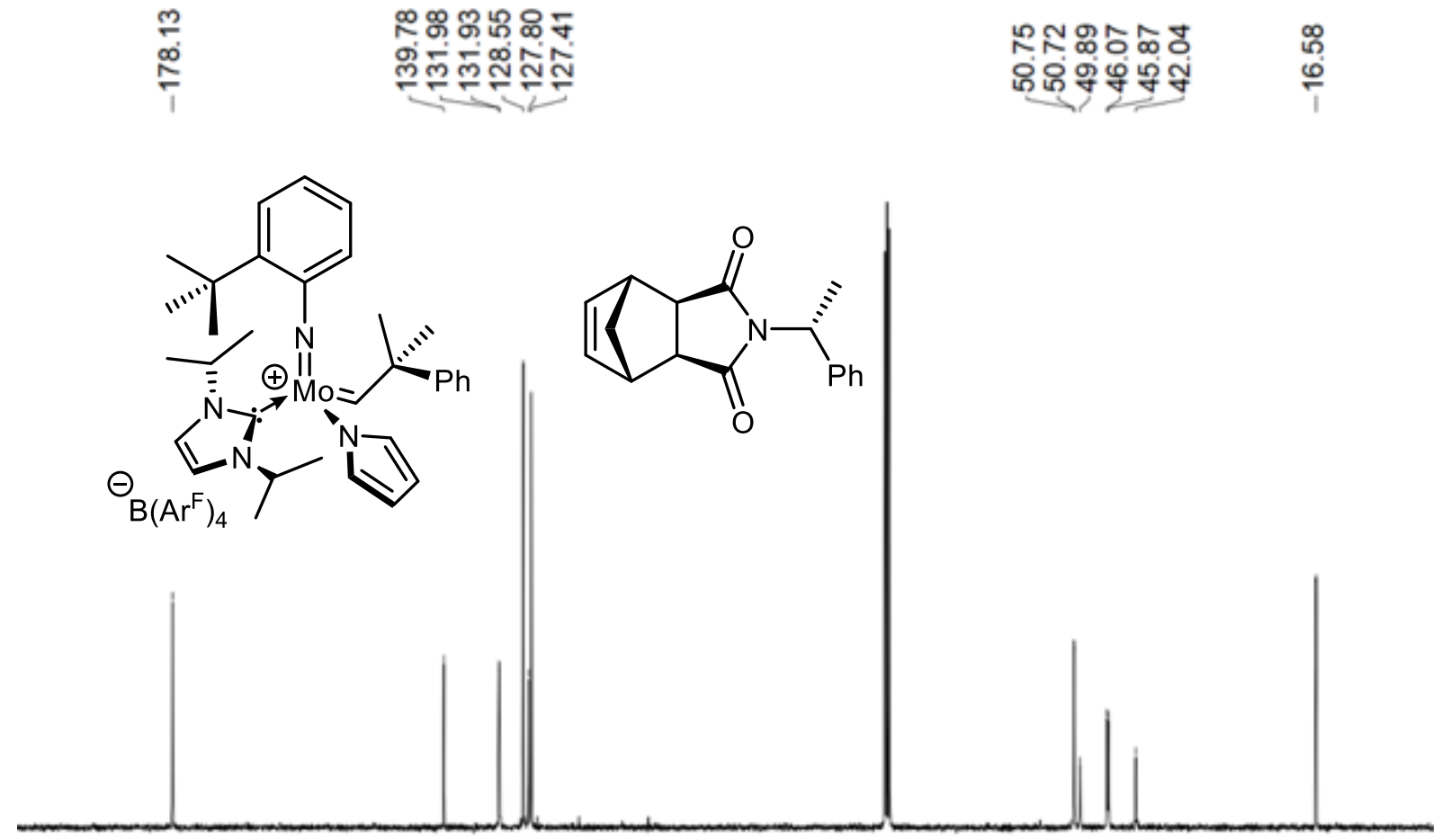

$\begin{array}{lllllllllllllllllllll}10 & 190 & 180 & 170 & 160 & 150 & 140 & 130 & 120 & 110 \underset{\delta(\mathrm{ppm})}{100} & 90 & 80 & 70 & 60 & 50 & 40 & 30 & 20 & 10 & 6\end{array}$

Figure S106: ${ }^{13} \mathrm{C}$ NMR spectrum (400 MHz) of poly(M5)//24 in $\mathrm{CDCl}_{3}$.

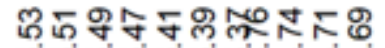

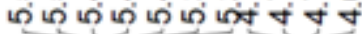

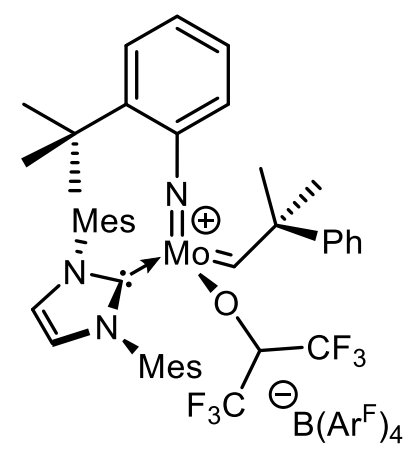
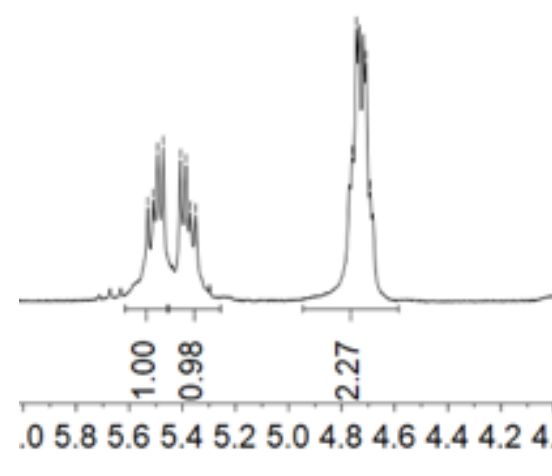

○ $\stackrel{\infty}{\circ}$

ลั<smiles>COC(=O)C1=C(C(=O)OC)[C@H]2C=C[C@@H]1C2</smiles>

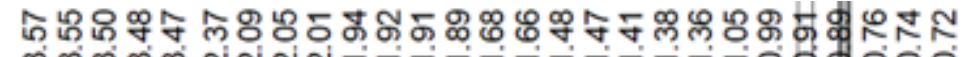
लmmल NNNN-F-F- - - - -

Figure S107: ${ }^{1} \mathrm{H}$ NMR spectrum $(400 \mathrm{MHz})$ of poly(M6)//21 in $\mathrm{CDCl}_{3}$. 

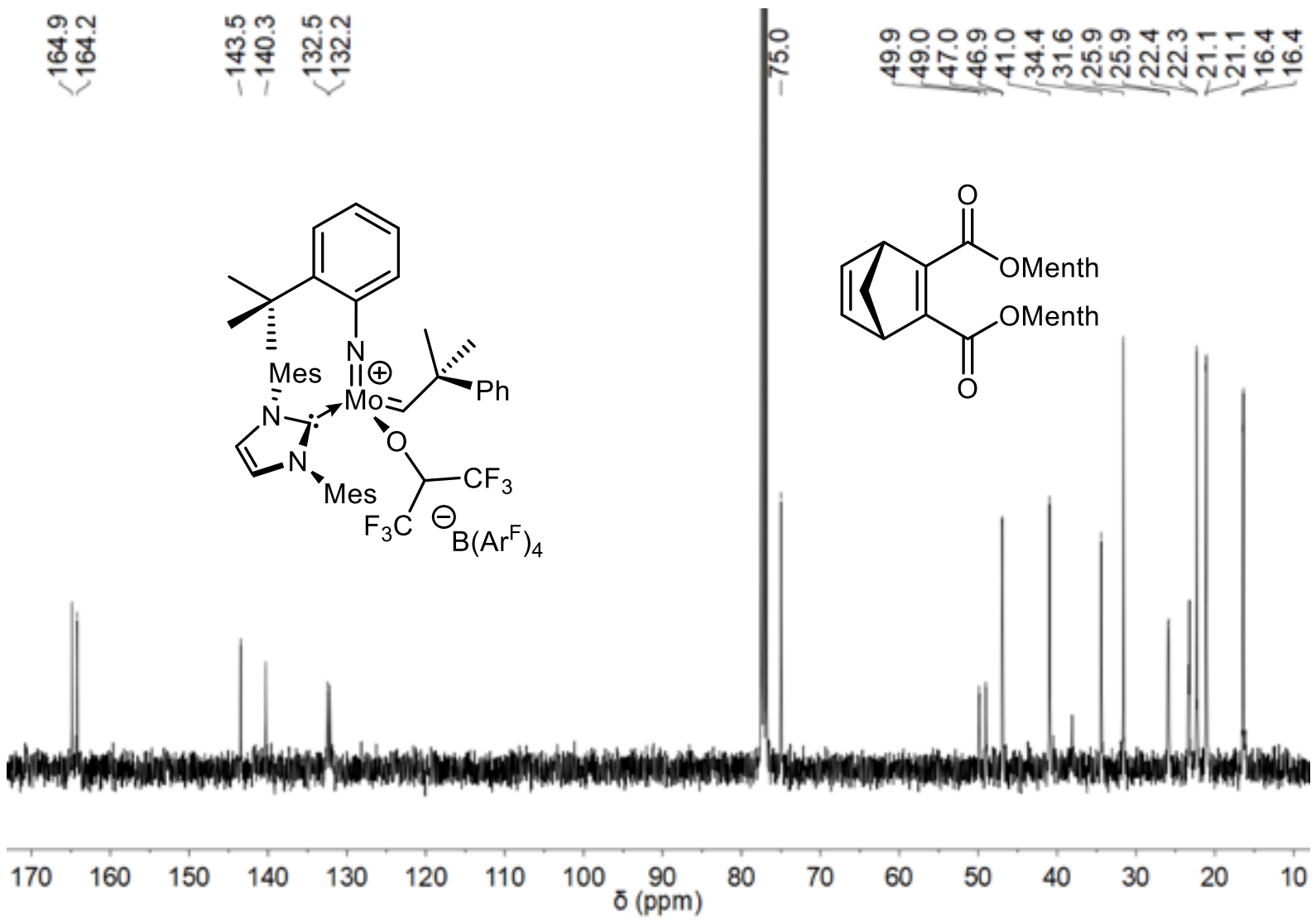

Figure S108: ${ }^{13} \mathrm{C}$ NMR spectrum $\left(400 \mathrm{MHz}\right.$ ) of poly(M6)//21 in $\mathrm{CDCl}_{3}$. 


\section{Kinetics}

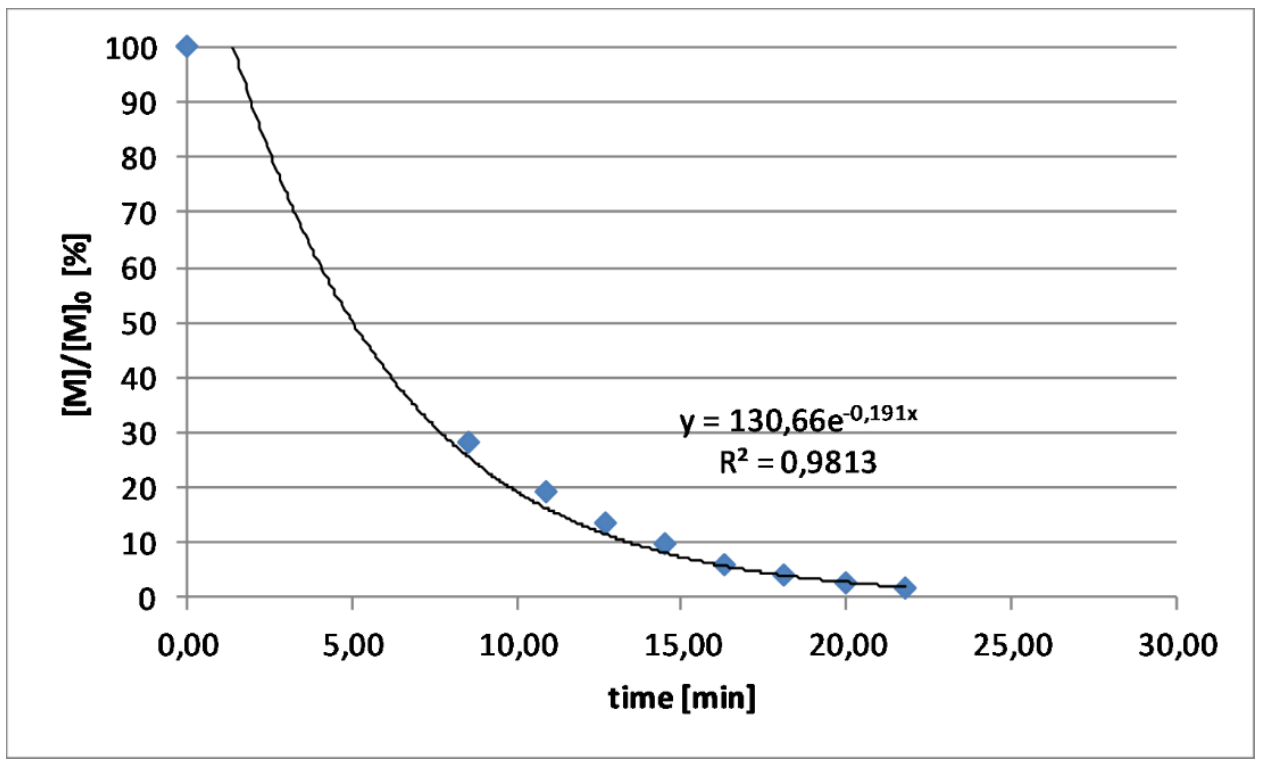

Figure S 109: Monomer conversion vs. time for Initiator I1 and $\mathbf{M} 1 . \mathrm{CDCl}_{3}$, r.t., $[\mathrm{M}]_{0}=0.25 \mathrm{M}$, $[\mathrm{M}] \mathrm{0} /[\mathrm{l}] 0=100$.

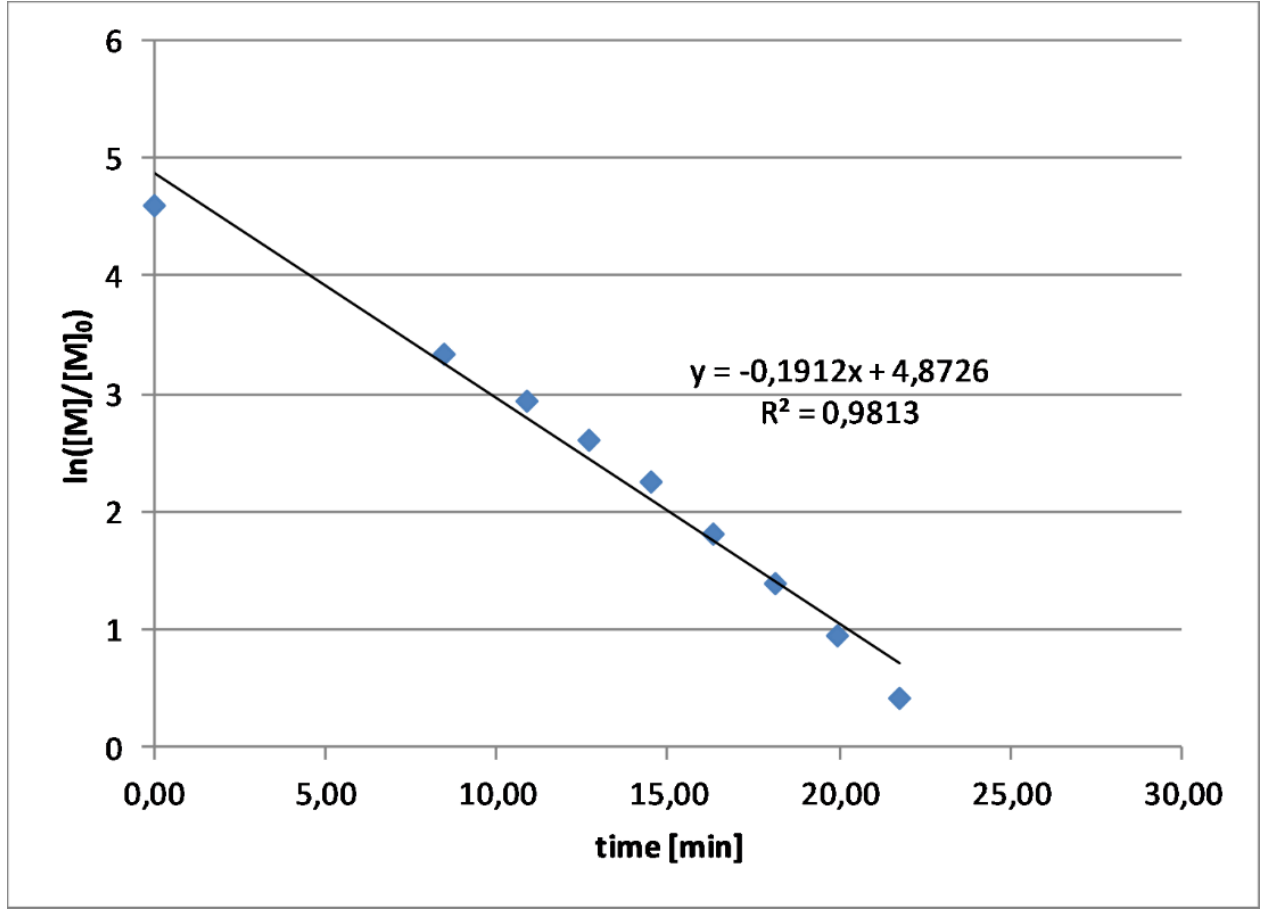

Figure S 110: $1^{\text {st }}$-order plot for Initiator I1 and M1. $\mathrm{CDCl}_{3}$, r.t., $[\mathrm{M}]_{0}=0.25 \mathrm{M},[\mathrm{M}]_{0} /[\mathrm{I}]_{0}=100$. 


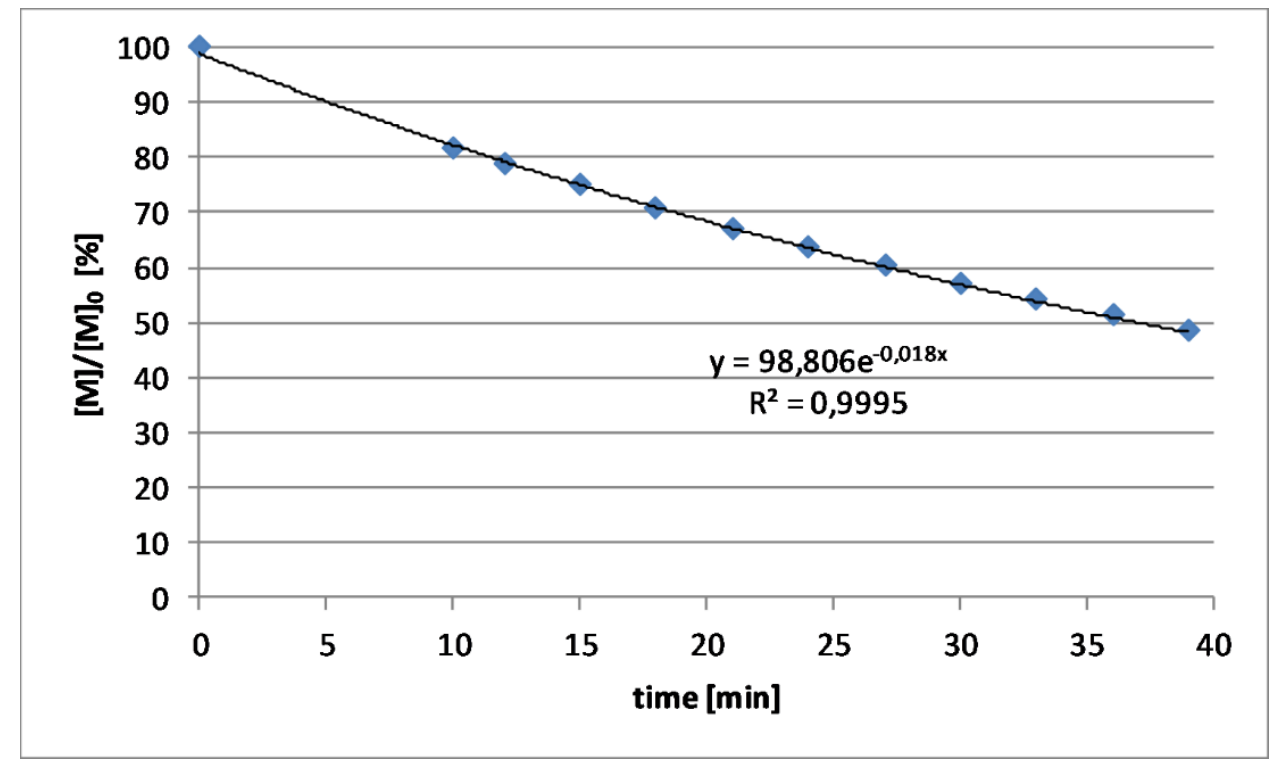

Figure S 111: Monomer conversion vs. time for Initiator $\mathbf{I 3}$ and $\mathbf{M} 1 . \mathrm{CDCl}_{3}$, r.t., $[\mathrm{M}]_{0}=0.25 \mathrm{M}$, $[\mathrm{M}]_{0} /[]_{0}=100$.

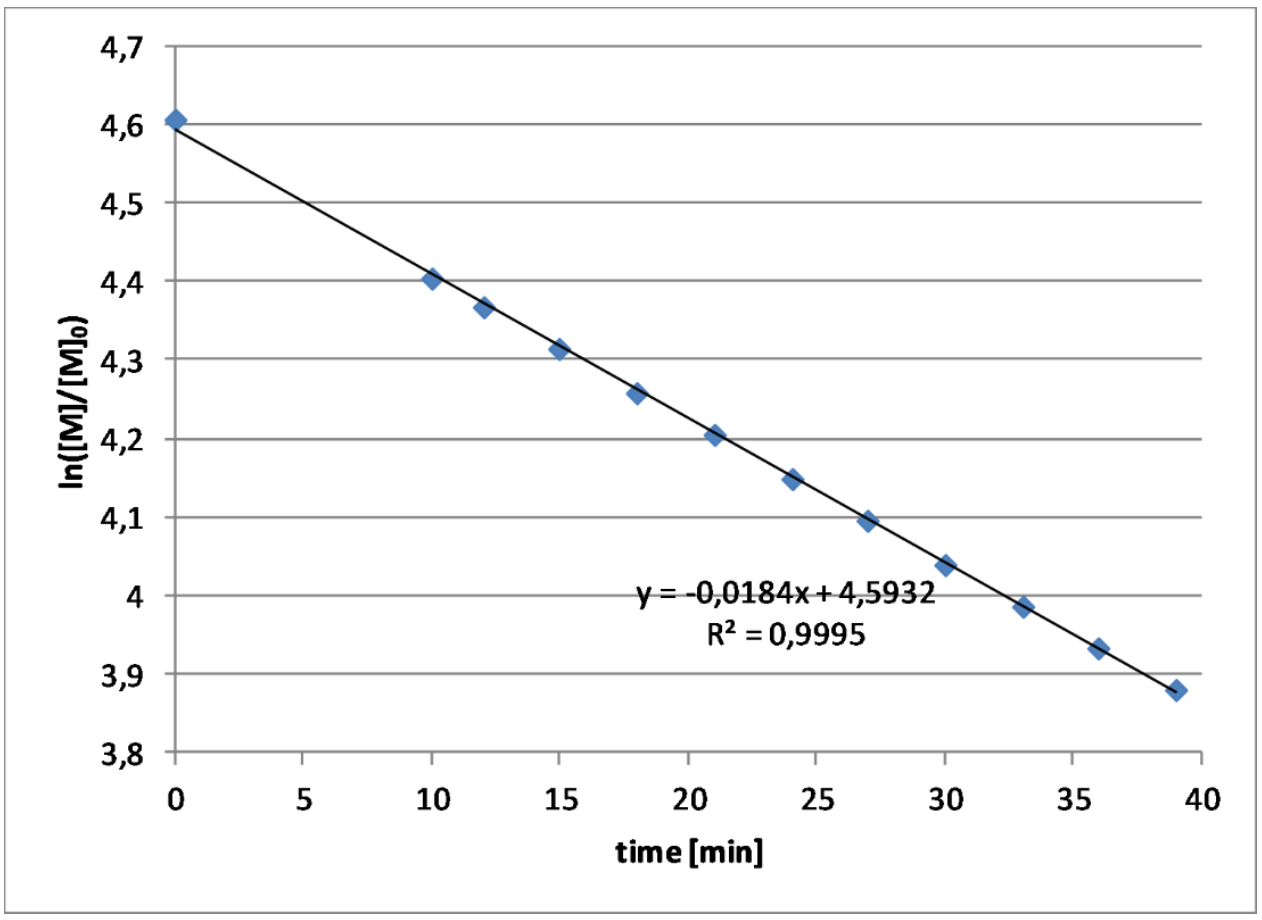

Figure S 112: $1^{\text {st }}$-order plot for Initiator I3 and M1. $\mathrm{CDCl}_{3}$, r.t., $[\mathrm{M}]_{0}=0.25 \mathrm{M}$, $[\mathrm{M}]_{0} /[]_{0}=100$. 


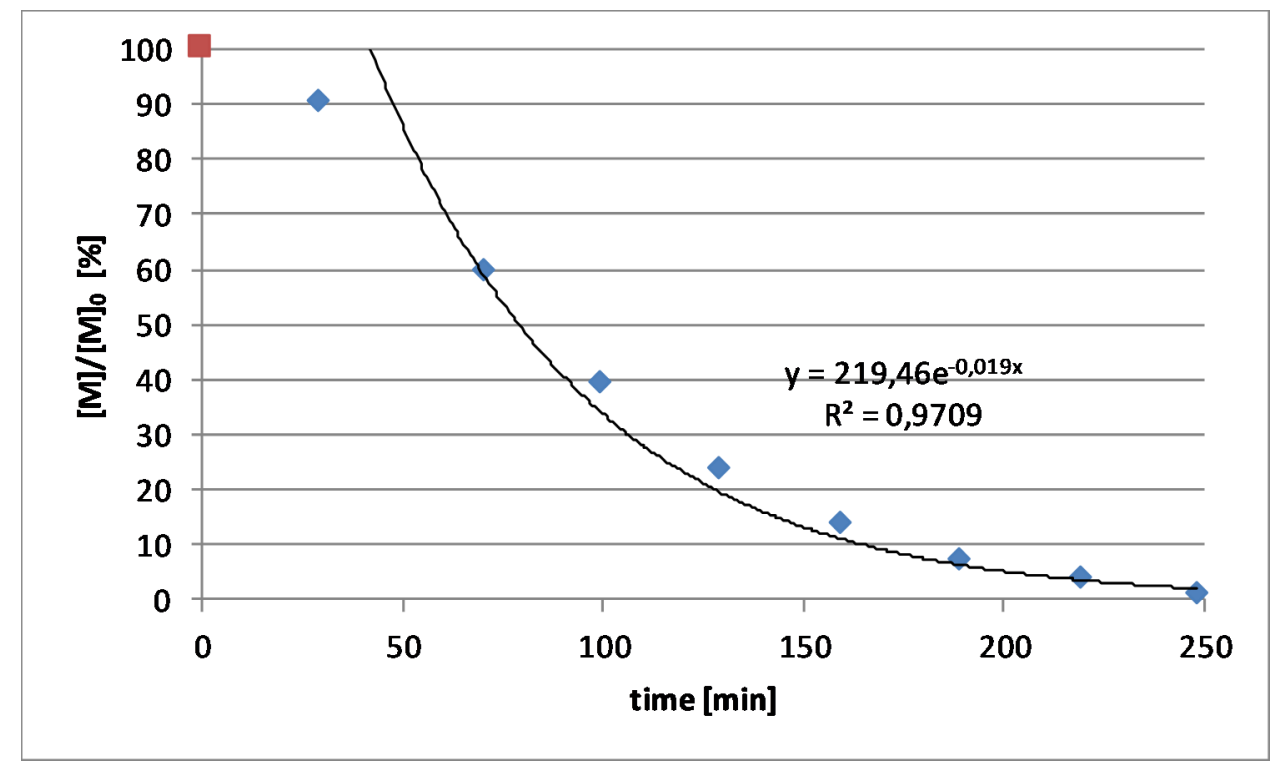

Figure S113: Monomer conversion vs. time for Initiator $\mathbf{1 7}$ and $\mathbf{M} 1 . \mathrm{CDCl}_{3}$, r.t., $[\mathrm{M}]_{0}=0.25 \mathrm{M}$, $[\mathrm{M}]_{0} /[]_{0}=100$. The red data point was not considered in the calculation in order to take the lengthy initiation period of the complex into account.

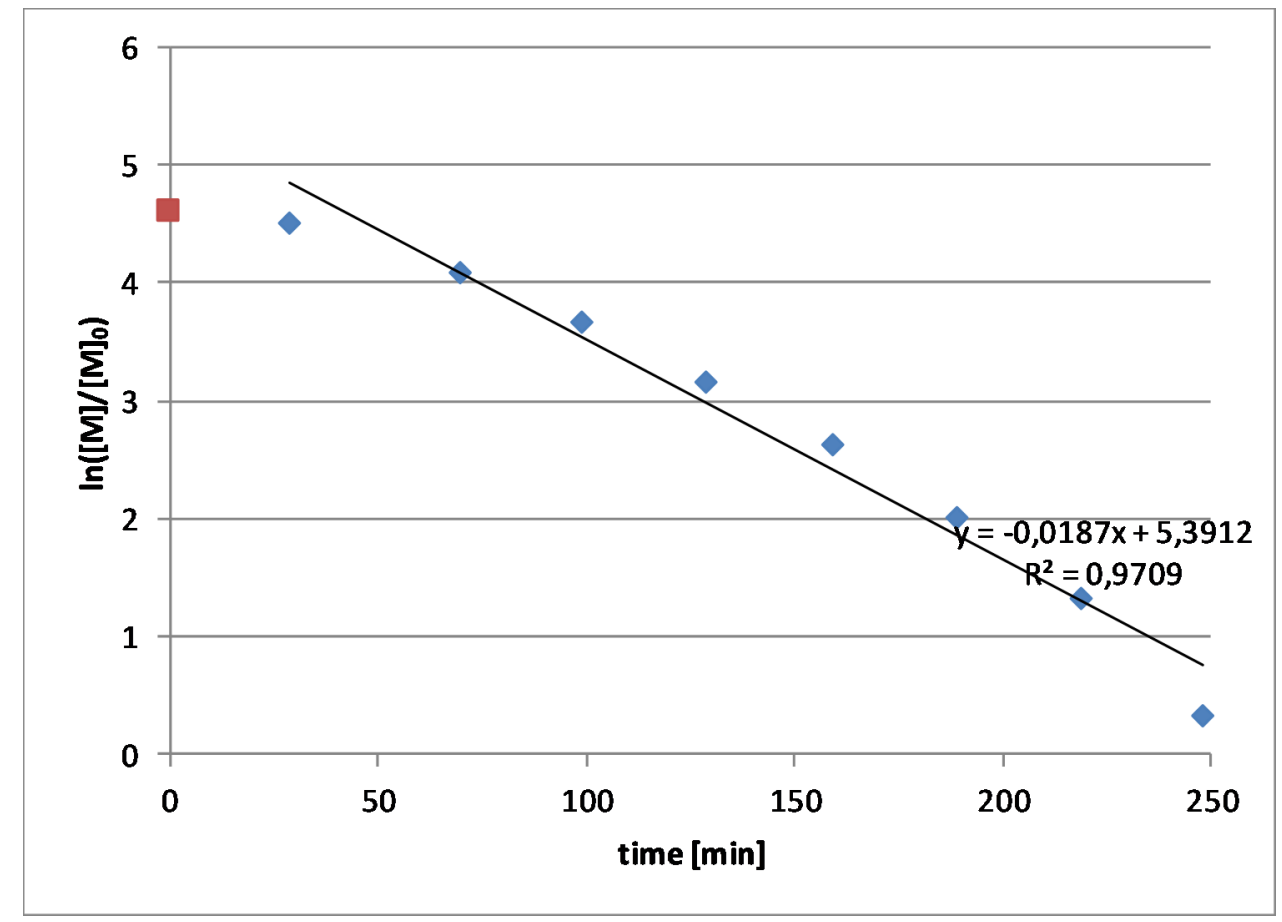

Figure S114: $1^{\text {st }}$-order plot for $\mathbf{I 7}$ and $\mathbf{M} 1 . \mathrm{CDCl}_{3}$, r.t., $[\mathrm{M}]_{0}=0.25 \mathrm{M},[\mathrm{M}]_{0} /[\mathrm{I}]_{0}=100$. The red data point was not considered in the calculation in order to take the lengthy initiation period of the complex into account. 


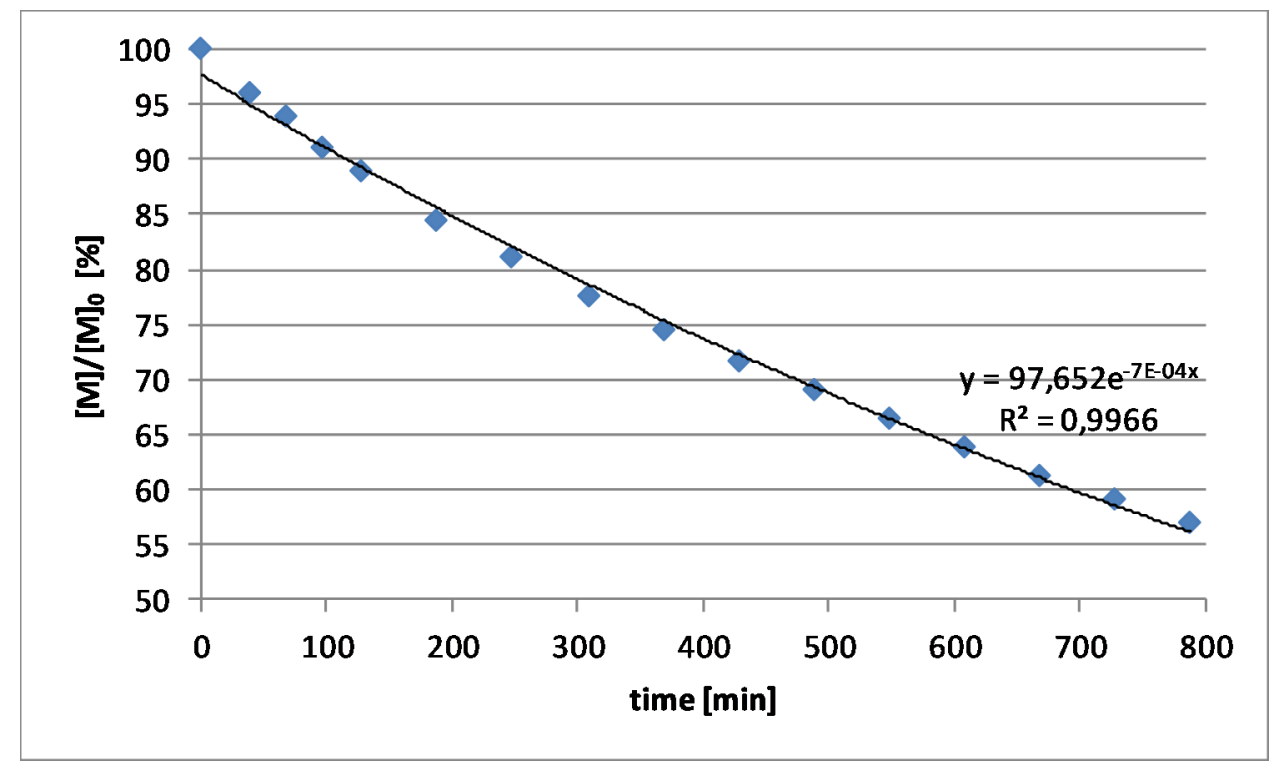

Figure S115: Monomer conversion vs. time for Initiator $\mathbf{I 1 5}$ and $\mathbf{M 1} . \mathrm{CDCl}_{3}$, r.t., $[\mathrm{M}]_{0}=0.25 \mathrm{M}$, $[\mathrm{M}]_{0} /[\mathrm{l}]_{0}=100$.

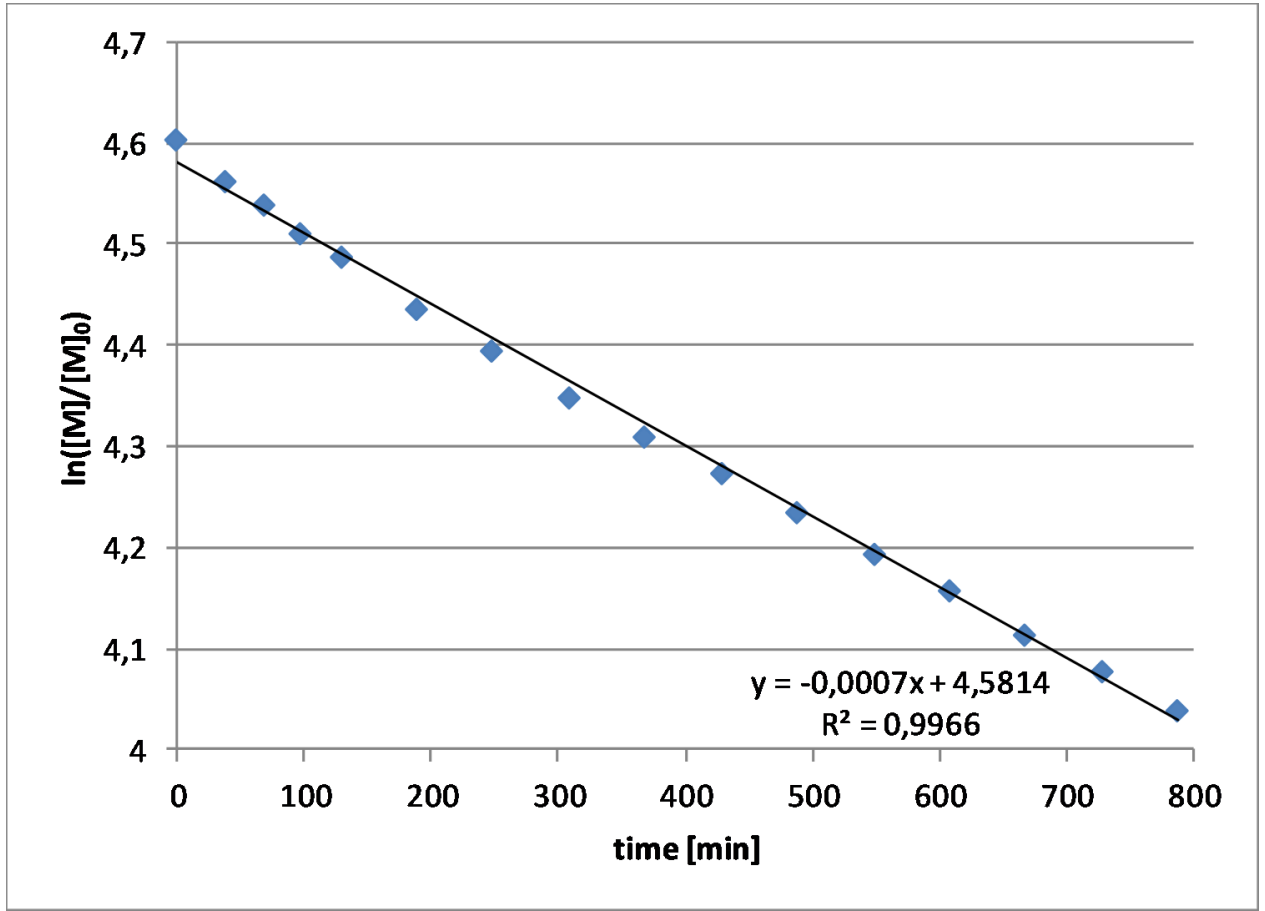

Figure S116: $1^{\text {st }}$-order plot for Initiator $\mathbf{I 1 5}$ and $\mathbf{M} 1 . \mathrm{CDCl}_{3}$, r.t., $[\mathrm{M}]_{0}=0.25 \mathrm{M},[\mathrm{M}]_{0} /[]_{0}=100$. 


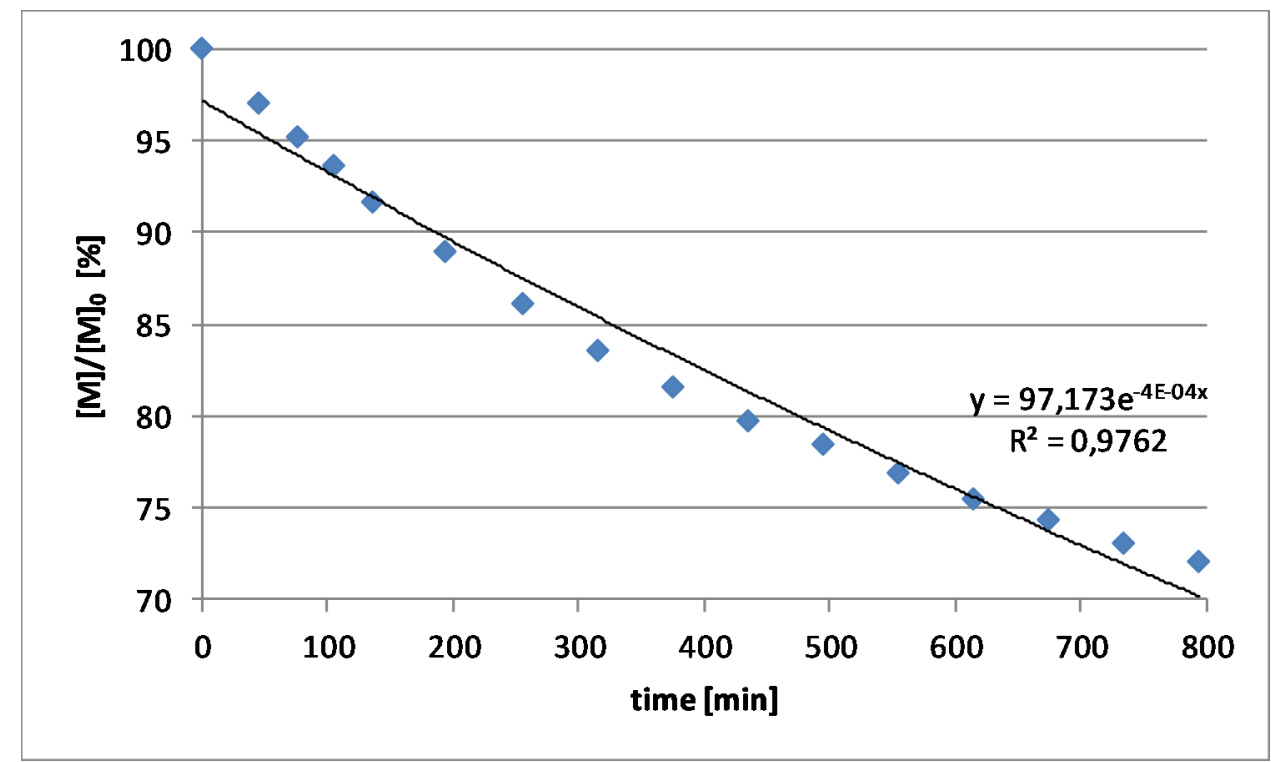

Figure S117: Monomer conversion vs. time for initiator $\mathbf{I} 15 \mathrm{MeCN}$ and $\mathbf{M} 1 . \mathrm{CDCl}_{3}$, r.t., $[\mathrm{M}]_{0}=0.25 \mathrm{M}$, $[\mathrm{M}]_{0} /[]_{0}=100$.

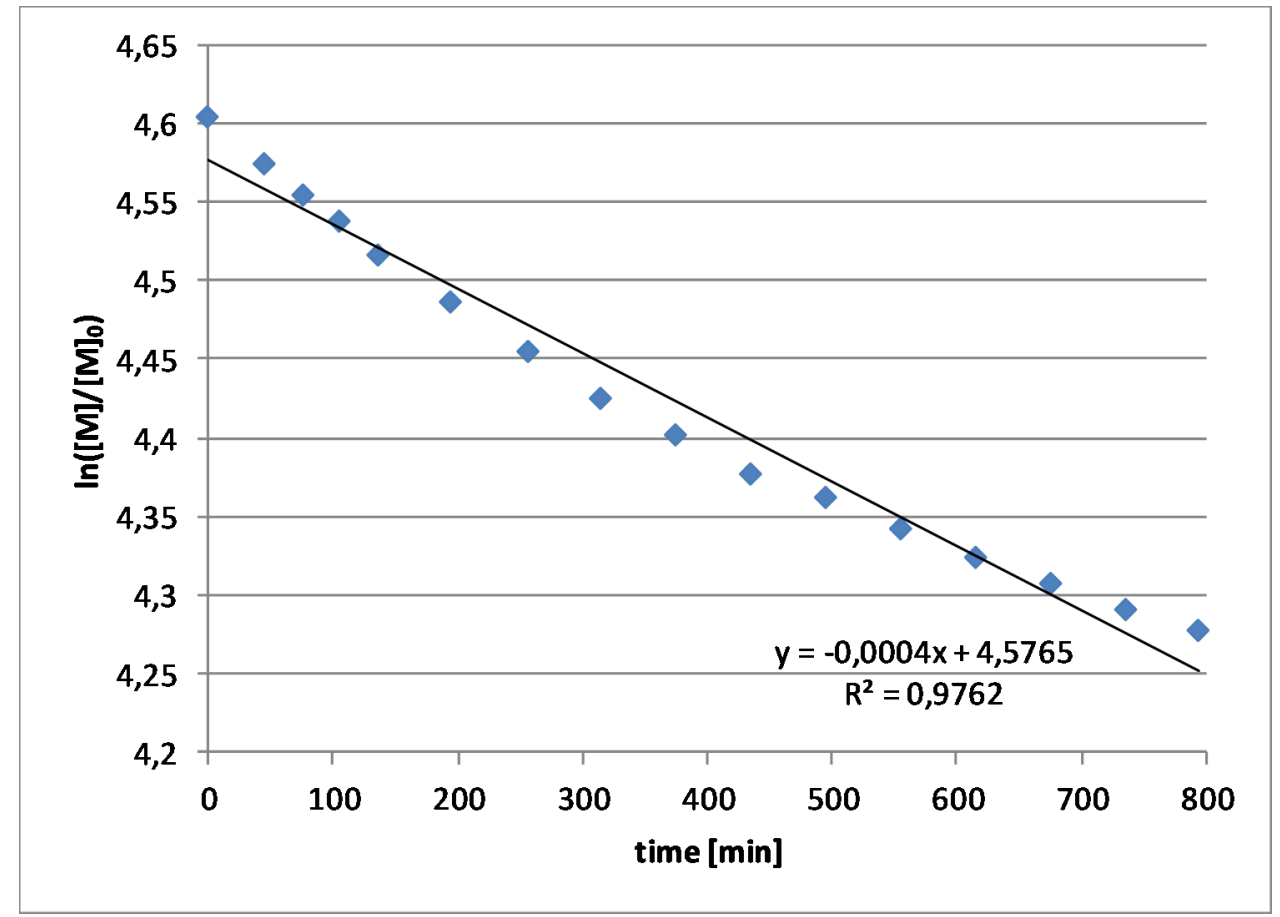

Figure S118: $1^{\text {st }}$-order plot for initiator $\mathbf{I} 15 \mathrm{MeCN}$ and $\mathbf{M 1} . \mathrm{CDCl}_{3}$, r.t., $[\mathrm{M}]_{0}=0.25 \mathrm{M}$, $[\mathrm{M}]_{0} /[]_{0}=100$. 


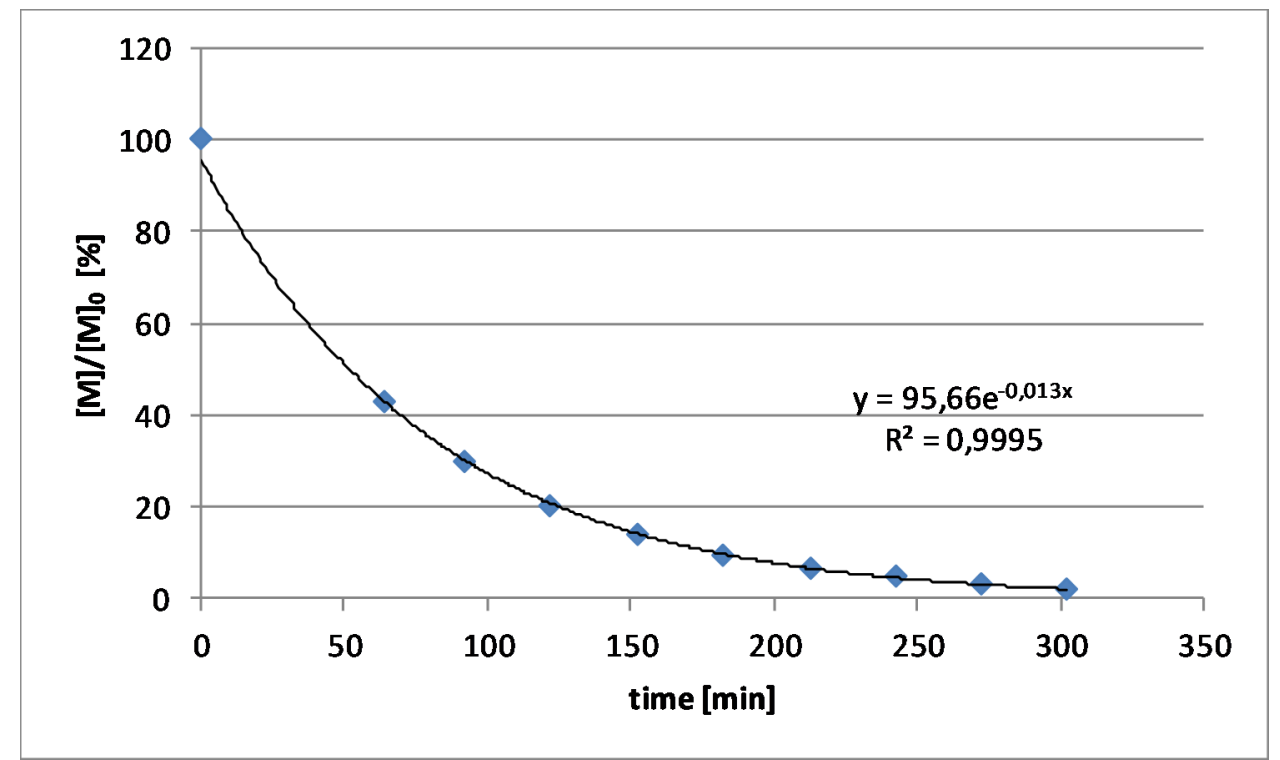

Figure S119: Monomer conversion vs. time for initiator I18 and M1. $\mathrm{CDCl}_{3}$, r.t., $[\mathrm{M}]_{0}=0.25 \mathrm{M}$, $[\mathrm{M}]_{0} /[\mathrm{l}]_{0}=100$.

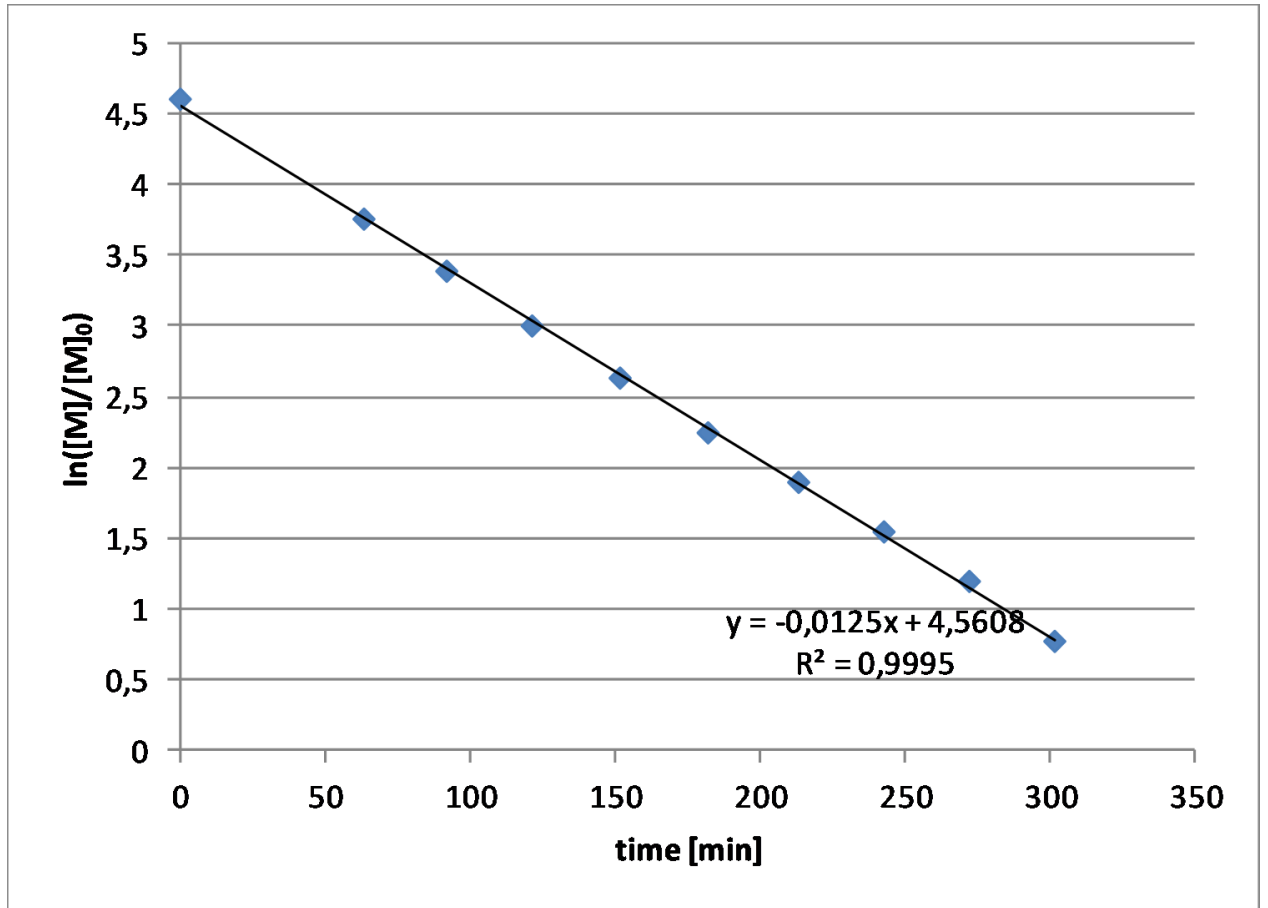

Figure S120: $1^{\text {st }}$-order plot for $\mathbf{I 1 8}$ and $\mathbf{M} 1 . \mathrm{CDCl}_{3}$, r.t., $[\mathrm{M}]_{0}=0.25 \mathrm{M}$, $\left.[\mathrm{M}]_{0} /[\mathrm{I}]\right]_{0}=100$. 


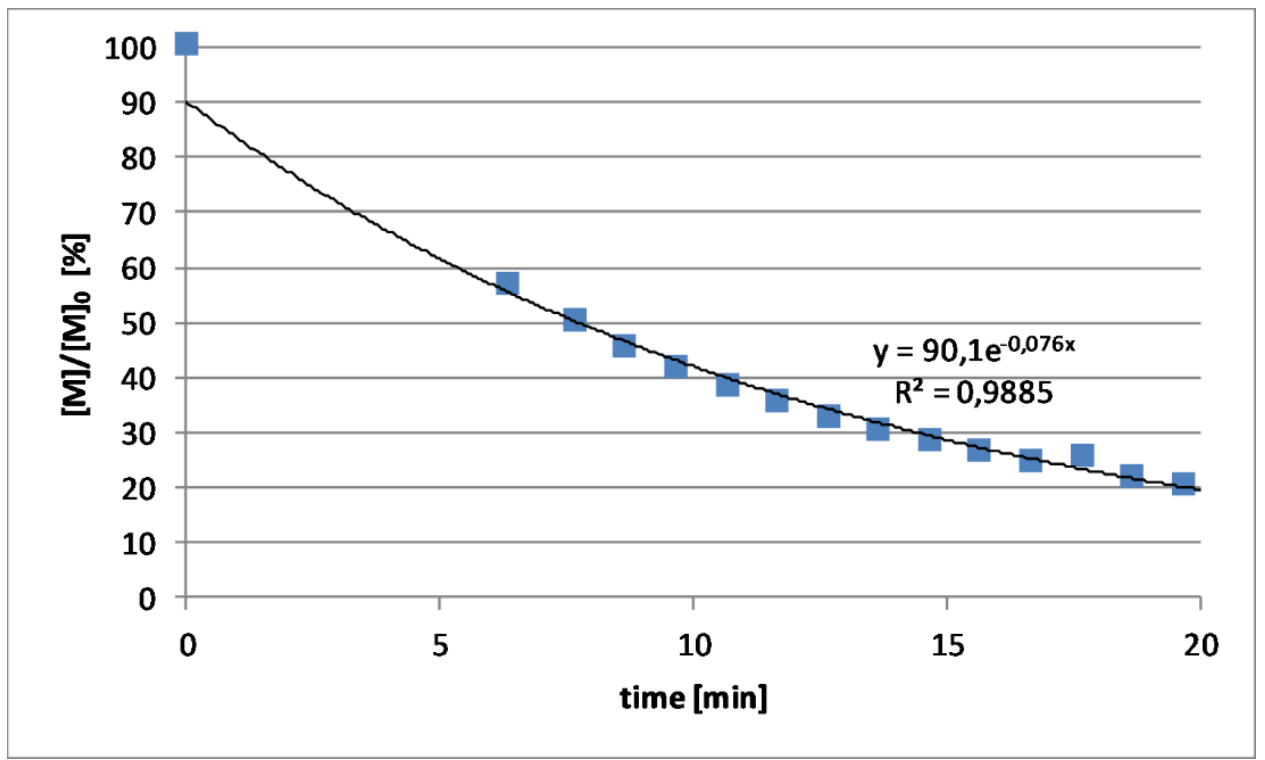

Figure S 121: Monomer conversion vs. time for initiator $\mathbf{I 2 2}$ and $\mathbf{M} 1 . \mathrm{CDCl}_{3}$, r.t., $[\mathrm{M}]_{0}=0.25 \mathrm{M}$, $[\mathrm{M}]_{0} /[\mathrm{l}]_{0}=100$.

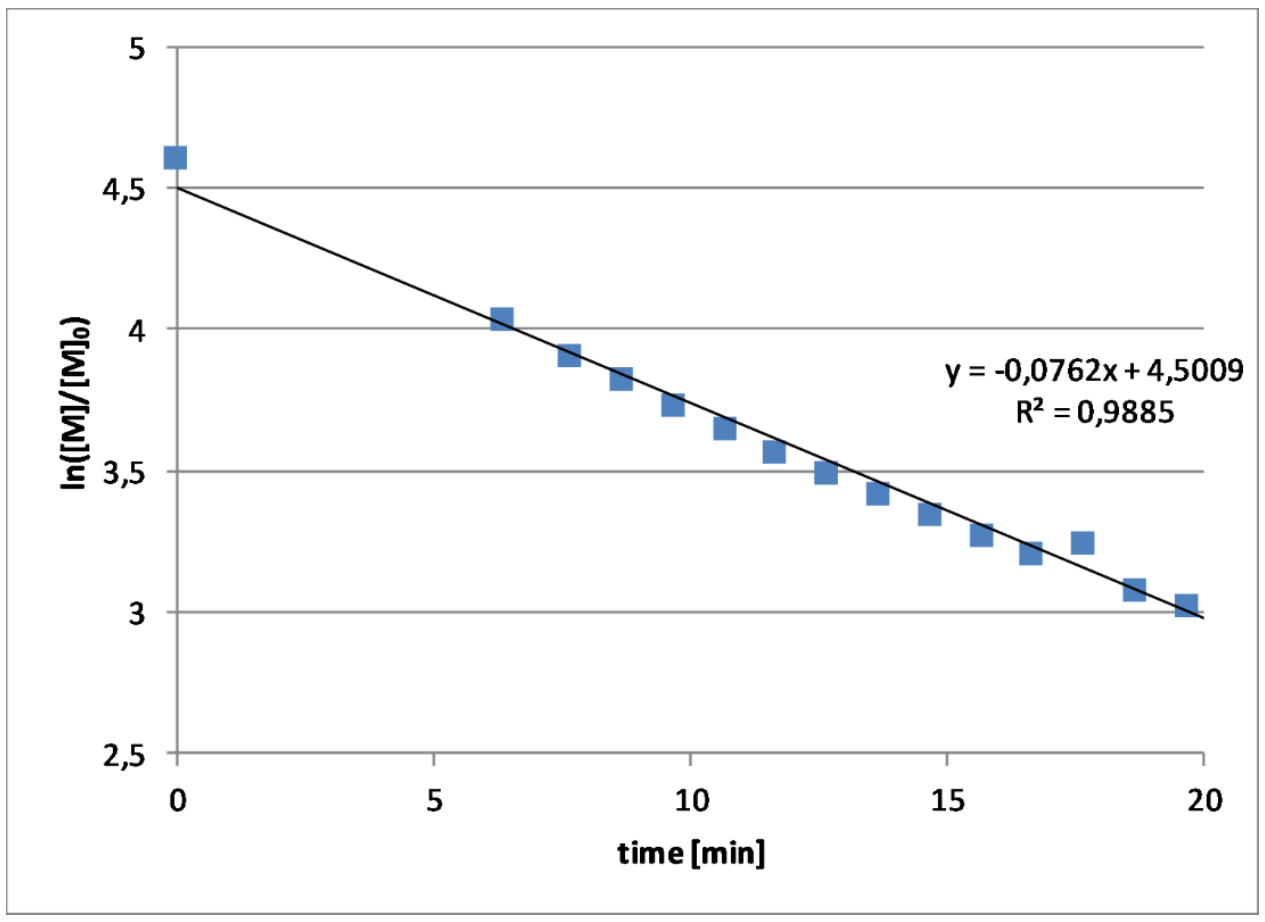

Figure S 122: $1^{\text {st }}$-order plot for $\mathbf{I 2 2}$ and $\mathbf{M} 1 . \mathrm{CDCl}_{3}$, r.t., $[\mathrm{M}]_{0}=0.25 \mathrm{M}$, $[\mathrm{M}]_{0} /[]_{0}=100$. 


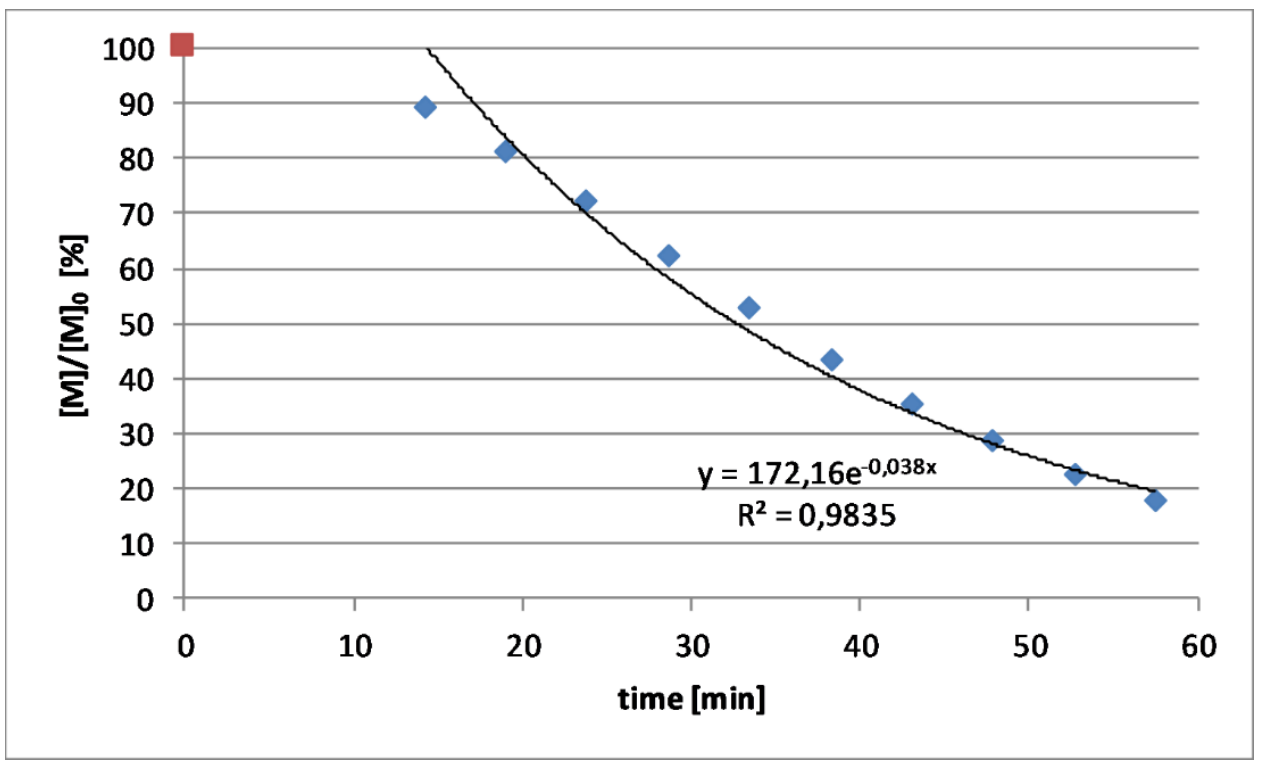

Figure S123: Monomer conversion vs. time for initiator $\mathbf{I 2 3}$ and $\mathbf{M} 1 . \mathrm{CDCl}_{3}$, r.t., $[\mathrm{M}]_{0}=0.25 \mathrm{M}$, $[\mathrm{M}]_{0} /[]_{0}=100$. The red data point was not considered in the calculation in order to take the lengthy initiation period of the complex into account.

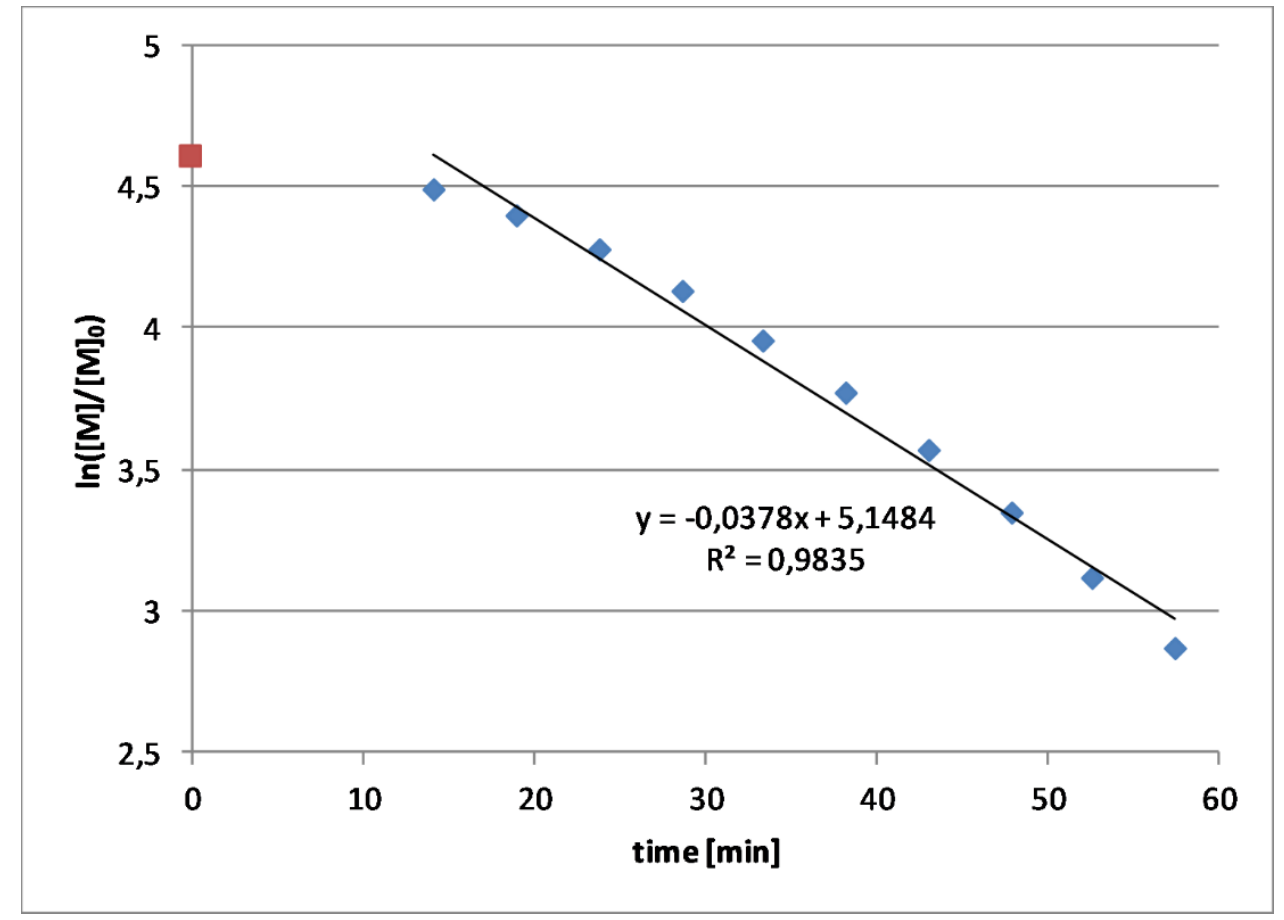

Figure S124: $1^{\text {st }}$-order plot for $\mathbf{I 2 3}$ and $\mathbf{M 1}$. $\mathrm{CDCl}_{3}$, r.t., $[\mathrm{M}]_{0}=0.25 \mathrm{M}$, $[\mathrm{M}]_{0} /[]_{0}=100$. The red data point was not considered in the calculation in order to take the lengthy initiation period of the complex into account. 


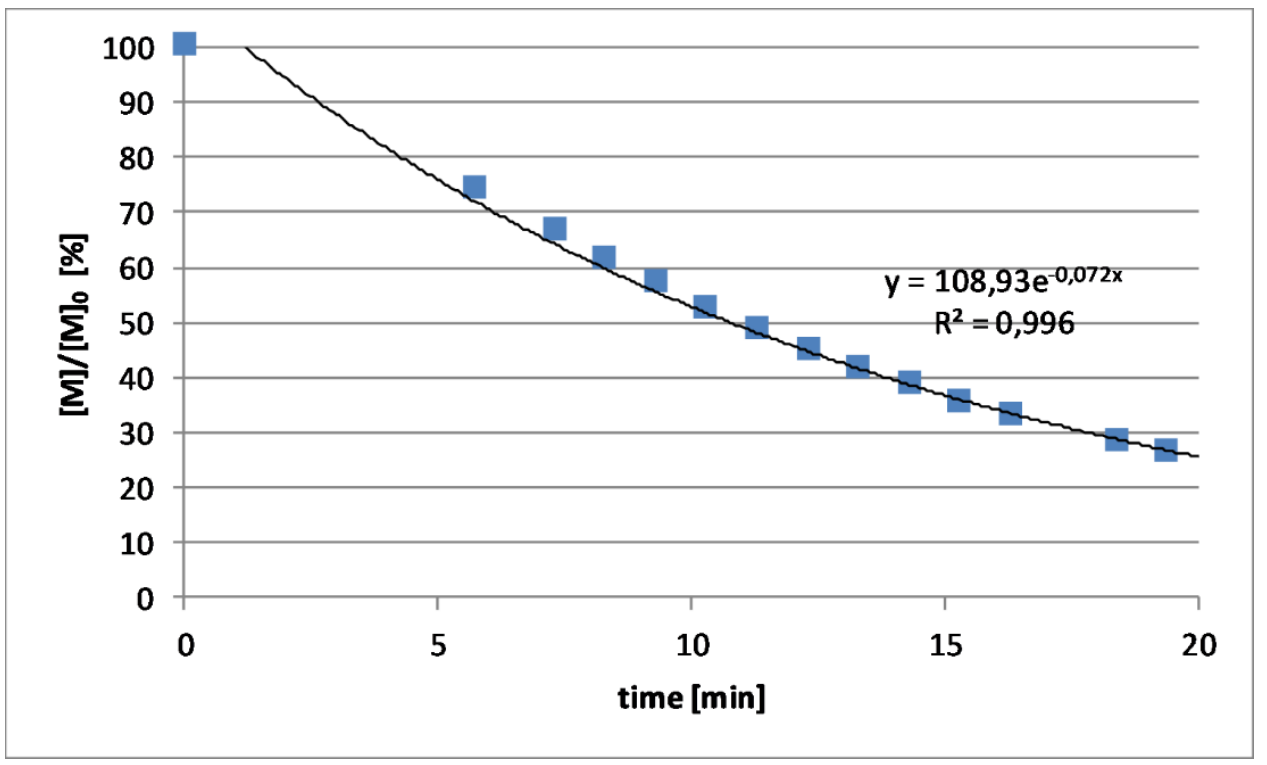

Figure S 125: Monomer conversion vs. time for initiator $\mathbf{I 2 4}$ and $\mathbf{M} 1 . \mathrm{CDCl}_{3}$, r.t., $[\mathrm{M}]_{0}=0.25 \mathrm{M}$, $[\mathrm{M}]_{0} /[\mathrm{l}]_{0}=100$.

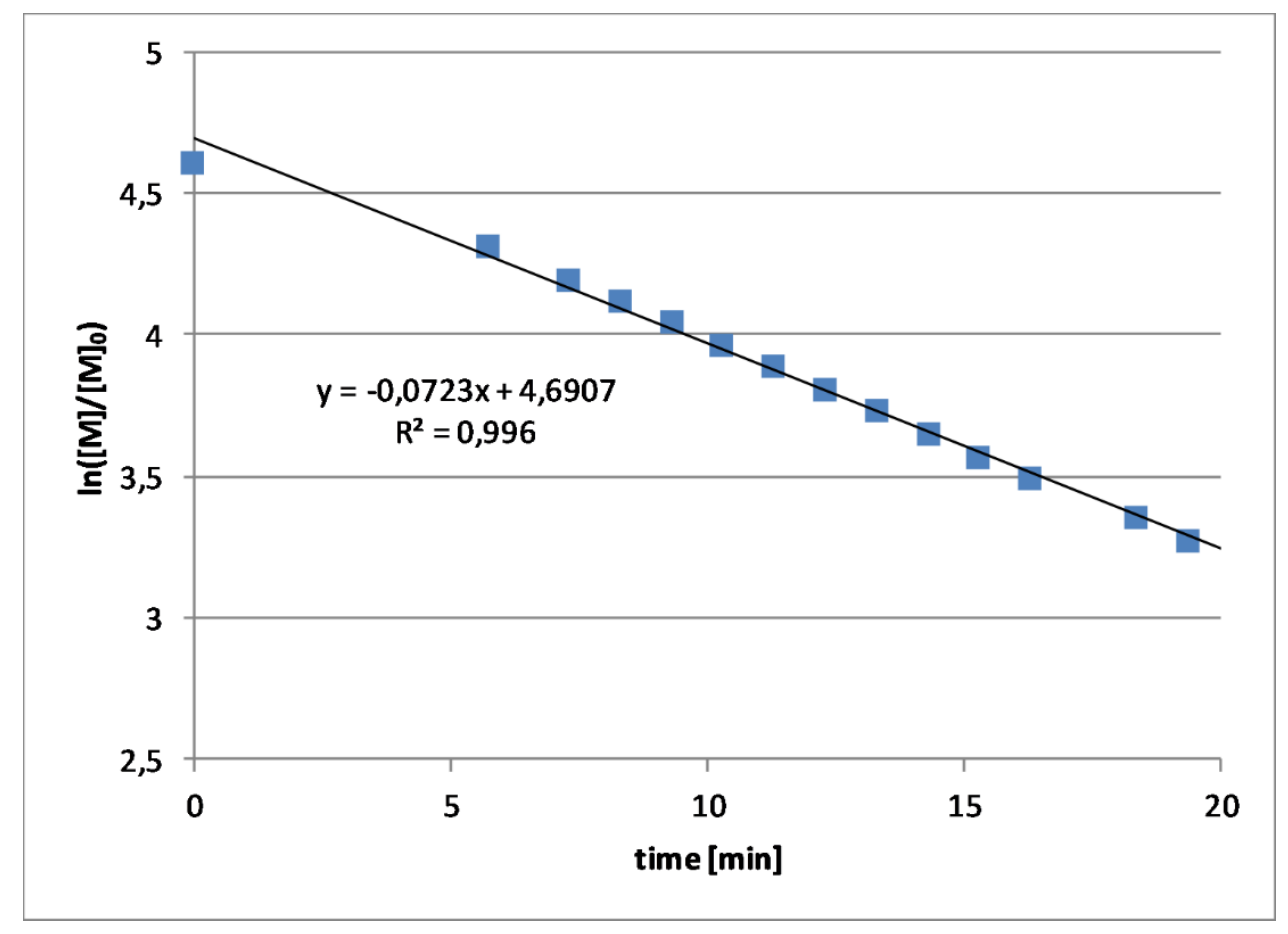

Figure S 126: $1^{\text {st }}$-order plot for initiator $\mathbf{I 2 4}$ and $\mathbf{M} 1 . \mathrm{CDCl}_{3}$, r.t., $[\mathrm{M}]_{0}=0.25 \mathrm{M},[\mathrm{M}]_{0} /[]_{0}=100$. 


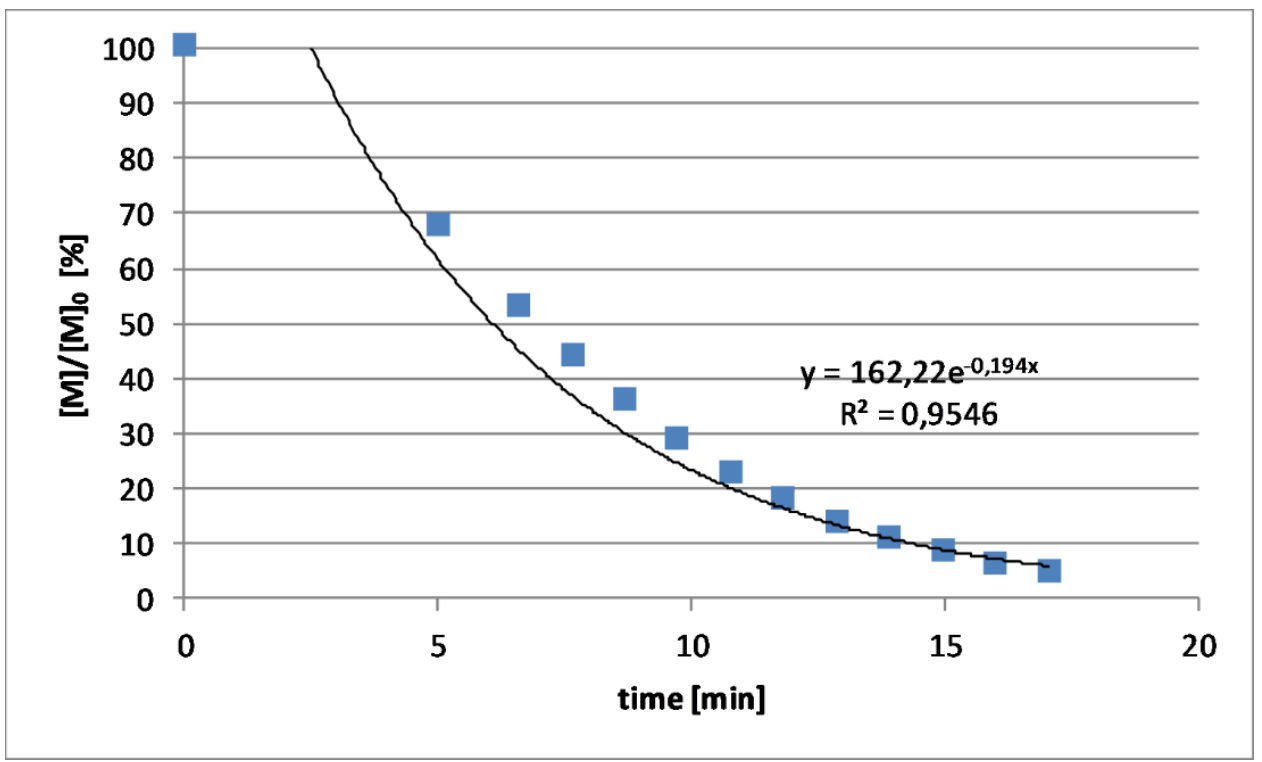

Figure S 127: Monomer conversion vs. time for initiator $\mathbf{I 2 5}$ and $\mathbf{M} 1 . \mathrm{CDCl}_{3}$, r.t., $[\mathrm{M}]_{0}=0.25 \mathrm{M}$, $[\mathrm{M}]_{0} /[\mathrm{l}]_{0}=100$.

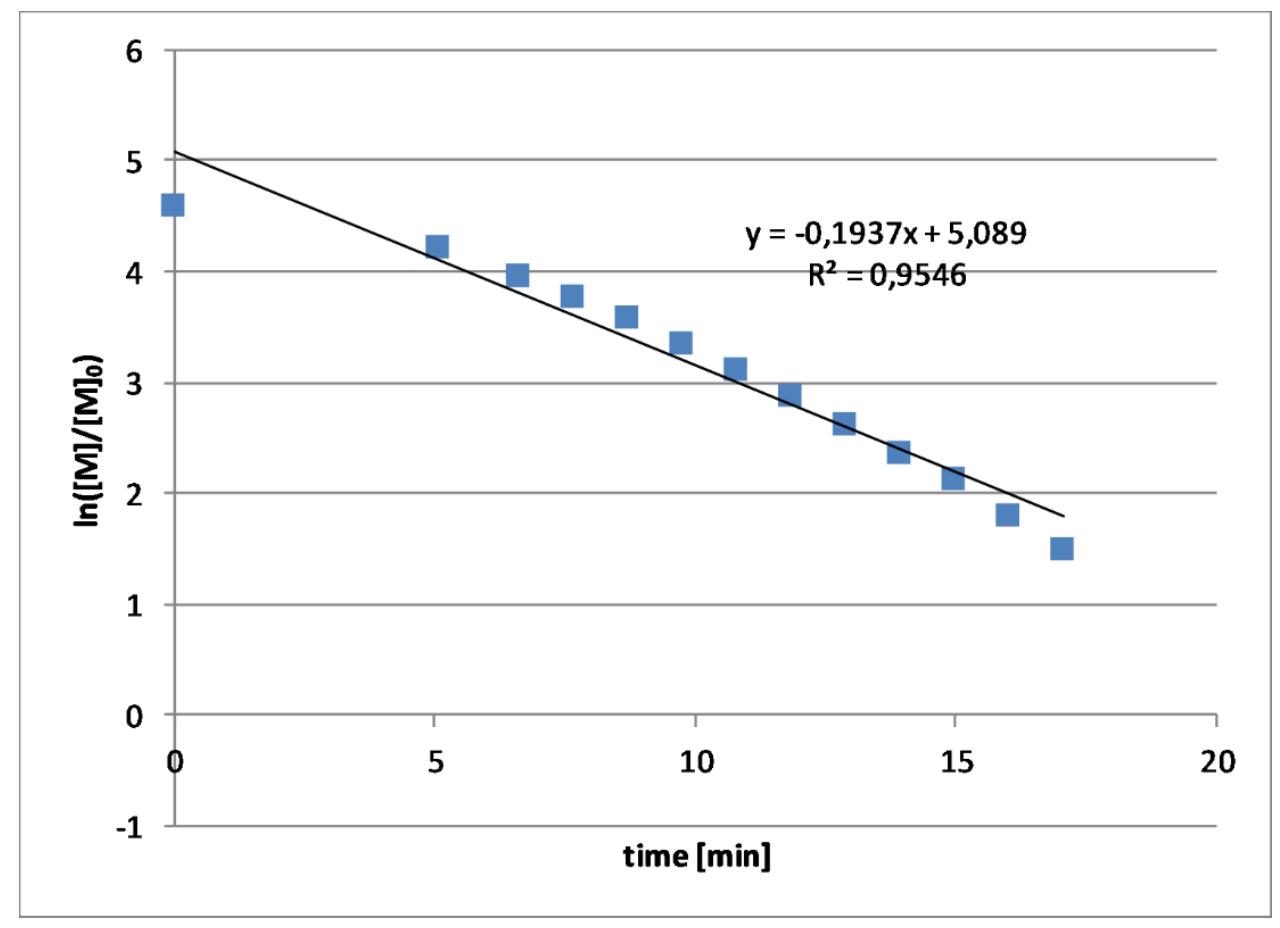

Figure S 128: $1^{\text {st }}$-order plot for initiator $\mathbf{I 2 5}$ and $\mathbf{M 1} . \mathrm{CDCl}_{3}$, r.t., $[\mathrm{M}]_{0}=0.25 \mathrm{M},[\mathrm{M}]_{0} /[]_{0}=100$. 


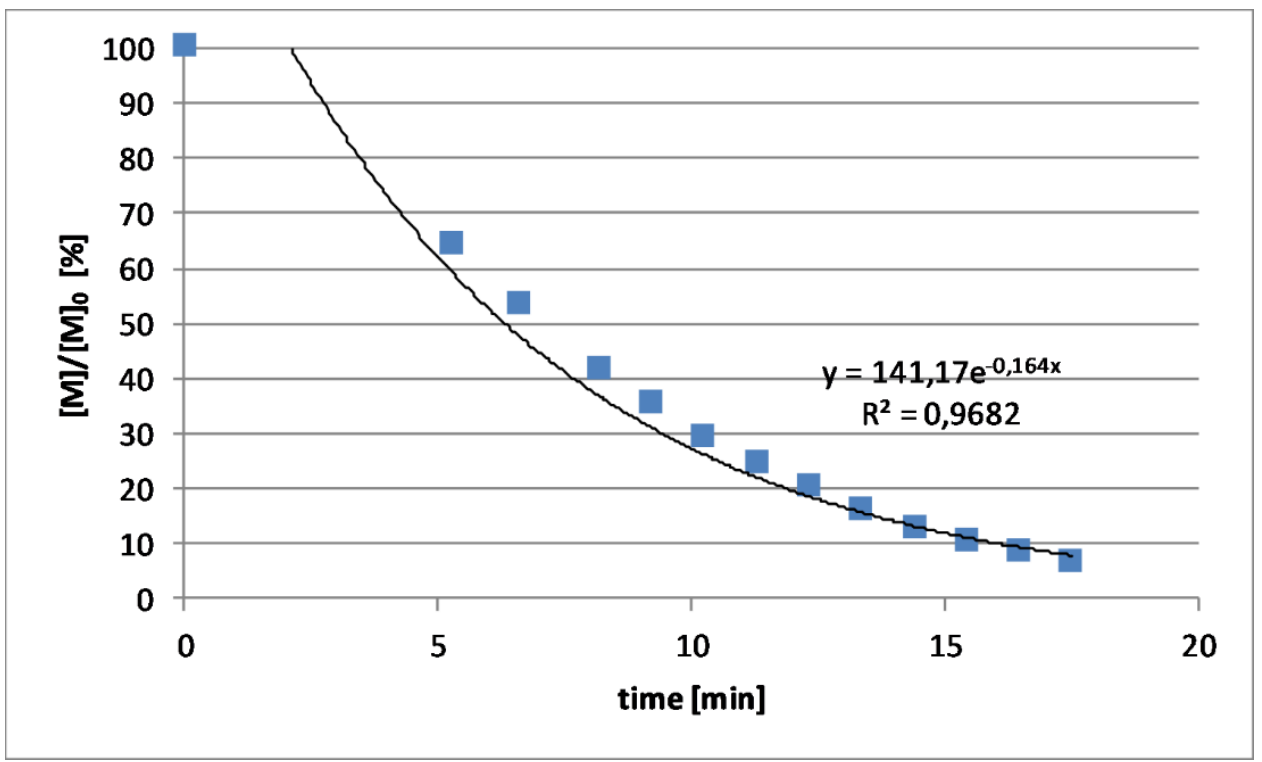

Figure S 129: Monomer conversion vs. time for initiator $\mathbf{I 2 6}$ and $\mathbf{M} 1 . \mathrm{CDCl}_{3}$, r.t., $[\mathrm{M}]_{0}=0.25 \mathrm{M}$, $[\mathrm{M}]_{0} /[\mathrm{l}]_{0}=100$.

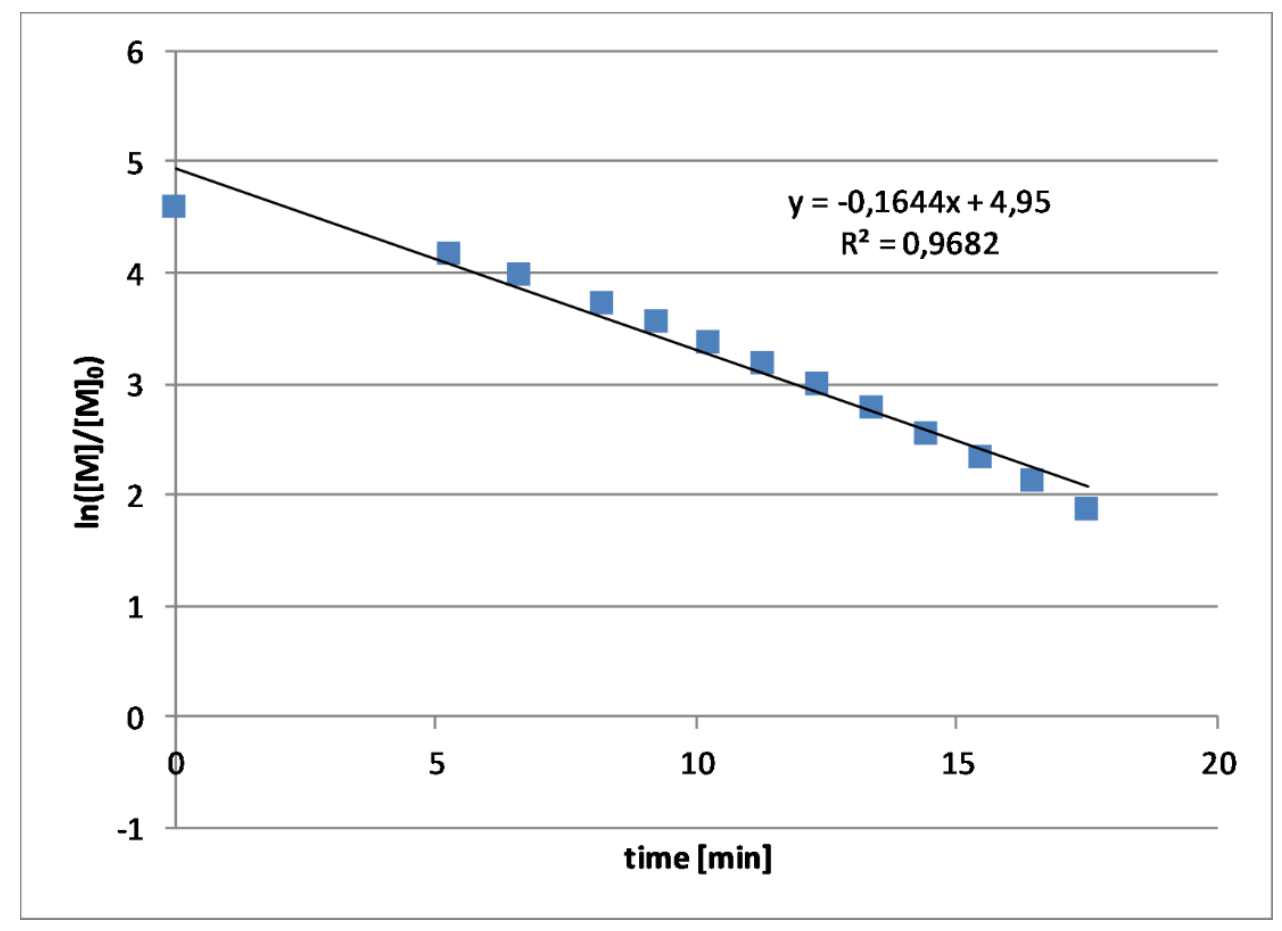

Figure S 130: $1^{\text {st }}$-order plot for initiator $\mathbf{I 2 6}$ and $\mathbf{M} 1 . \mathrm{CDCl}_{3}$, r.t., $[\mathrm{M}] 0=0.25 \mathrm{M},[\mathrm{M}] \mathrm{o} /[\mathrm{I}] \mathrm{0}=100$. 


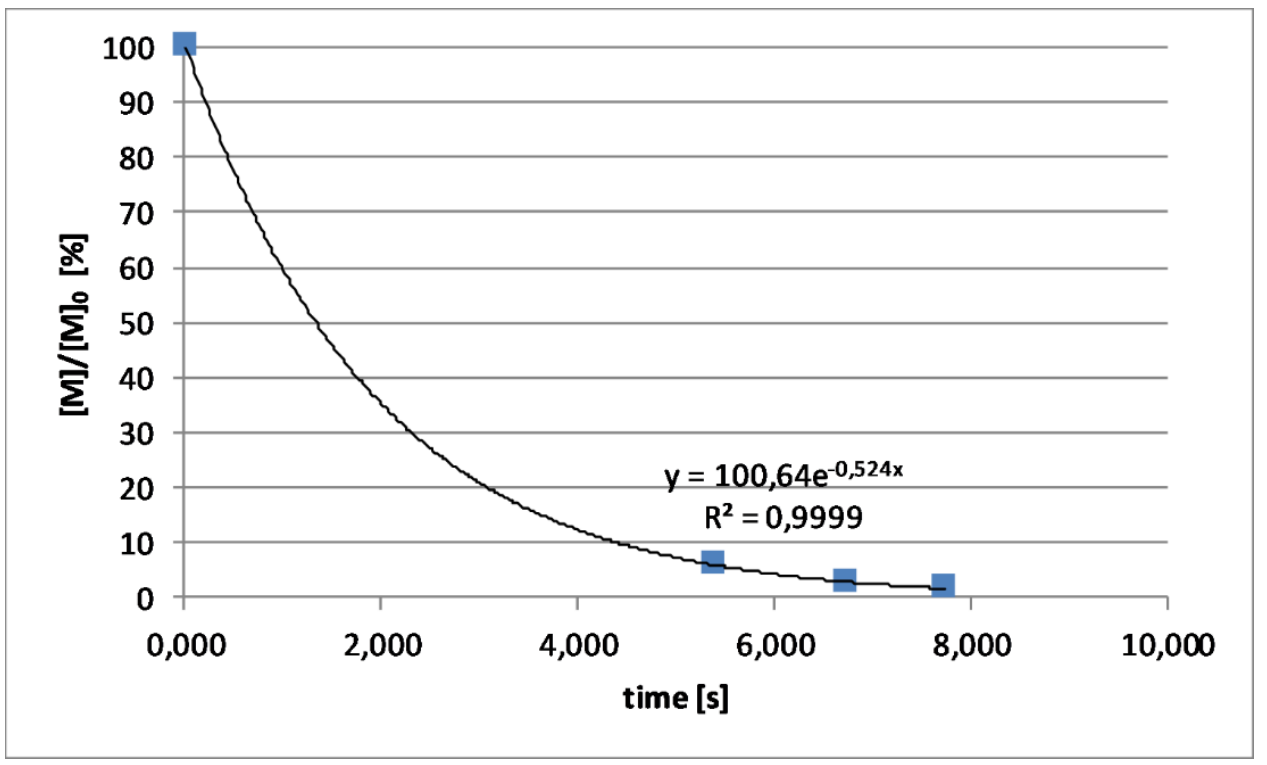

Figure S 131: Monomer conversion vs. time for initiator $\mathbf{I 2 7}$ and $\mathbf{M} 1 . \mathrm{CDCl}_{3}$, r.t., $[\mathrm{M}]_{0}=0.25 \mathrm{M}$, $[\mathrm{M}]_{0} /[\mathrm{l}]_{0}=100$.

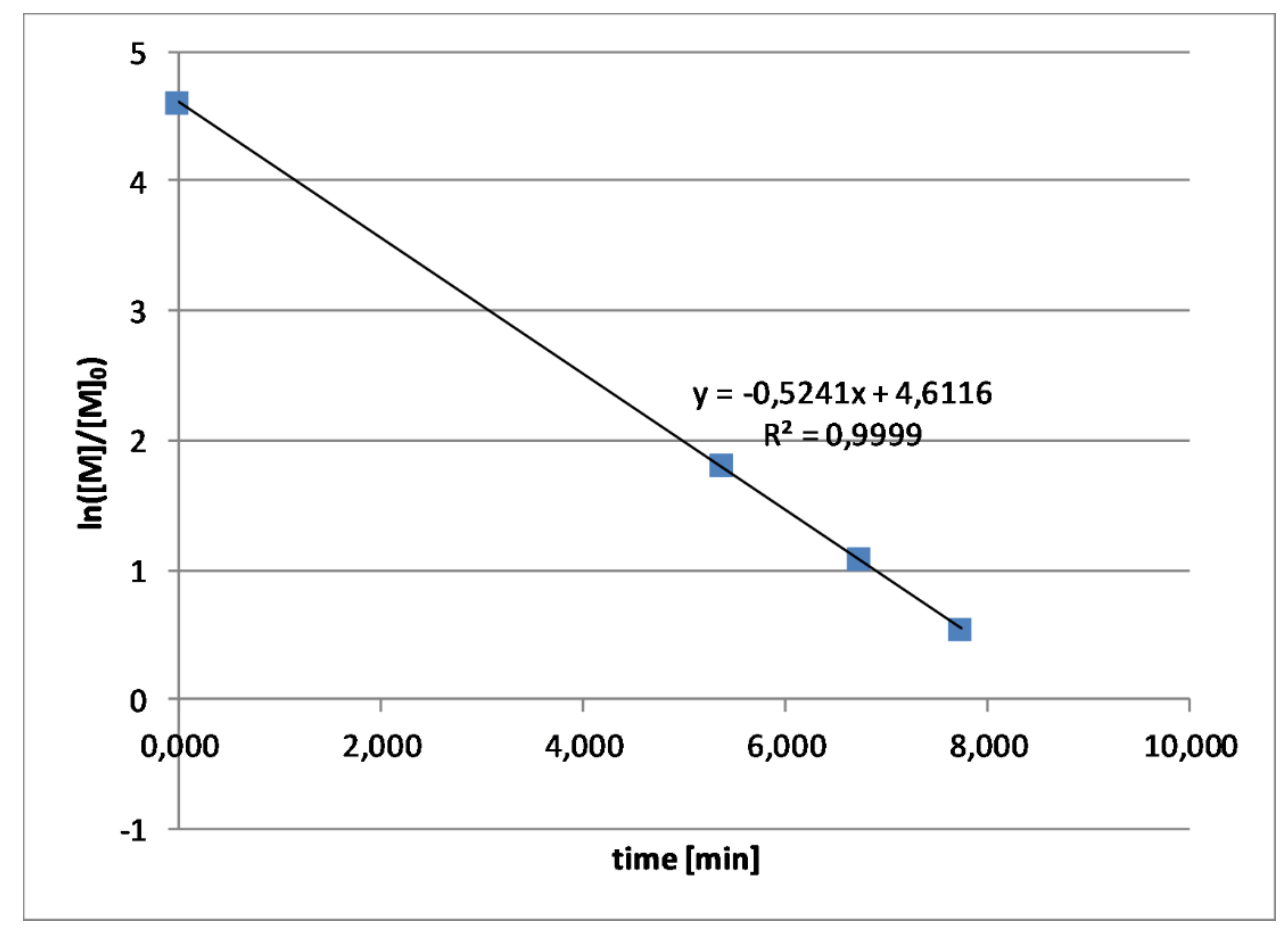

Figure S 132: $1^{\text {st }}$-order plot for initiator $\mathbf{I 2 7}$ and $\mathbf{M} 1 . \mathrm{CDCl}_{3}$, r.t., $[\mathrm{M}]_{0}=0.25 \mathrm{M},[\mathrm{M}]_{0} /\left[[]_{0}=100\right.$. 


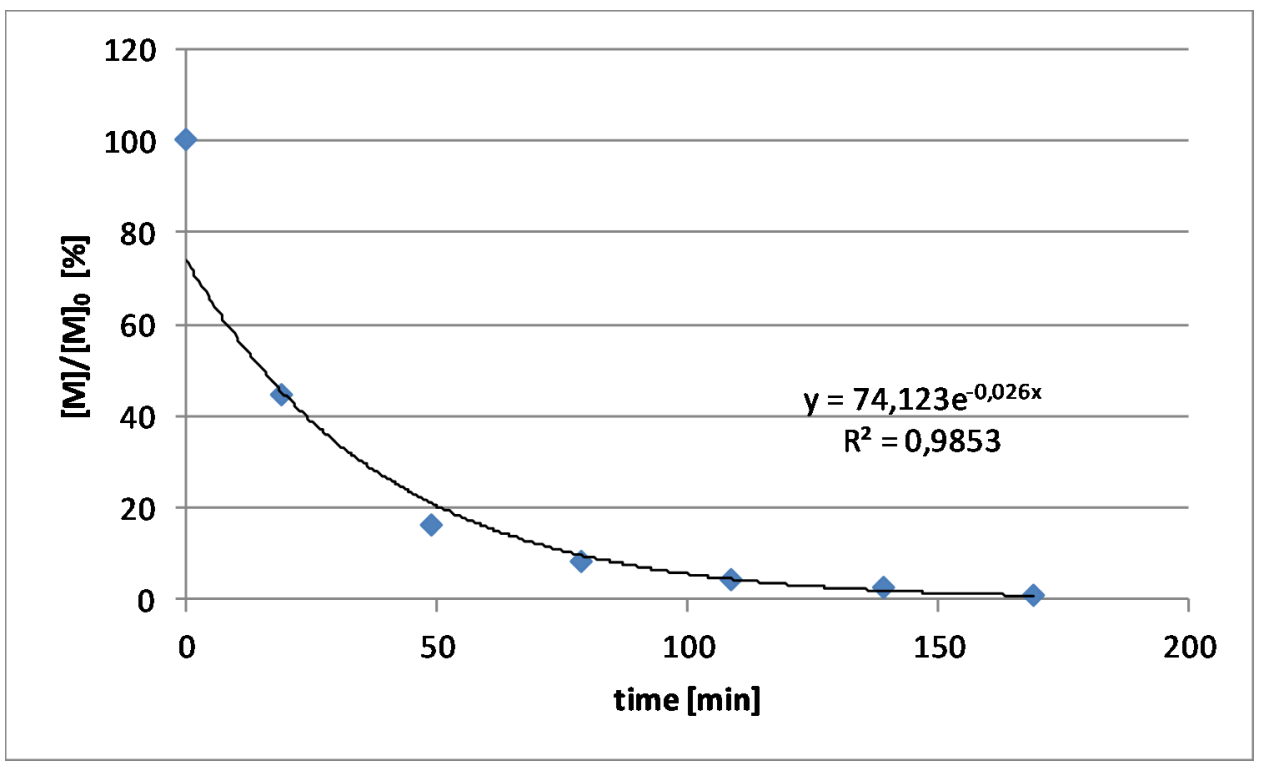

Figure S133: Monomer conversion vs. time for initiator $\mathbf{I 2 8}$ and $\mathbf{M} 1 . \mathrm{CDCl}_{3}$, r.t., $[\mathrm{M}]_{0}=0.25 \mathrm{M}$, $[\mathrm{M}]_{0} /[\mathrm{l}]_{0}=100$.

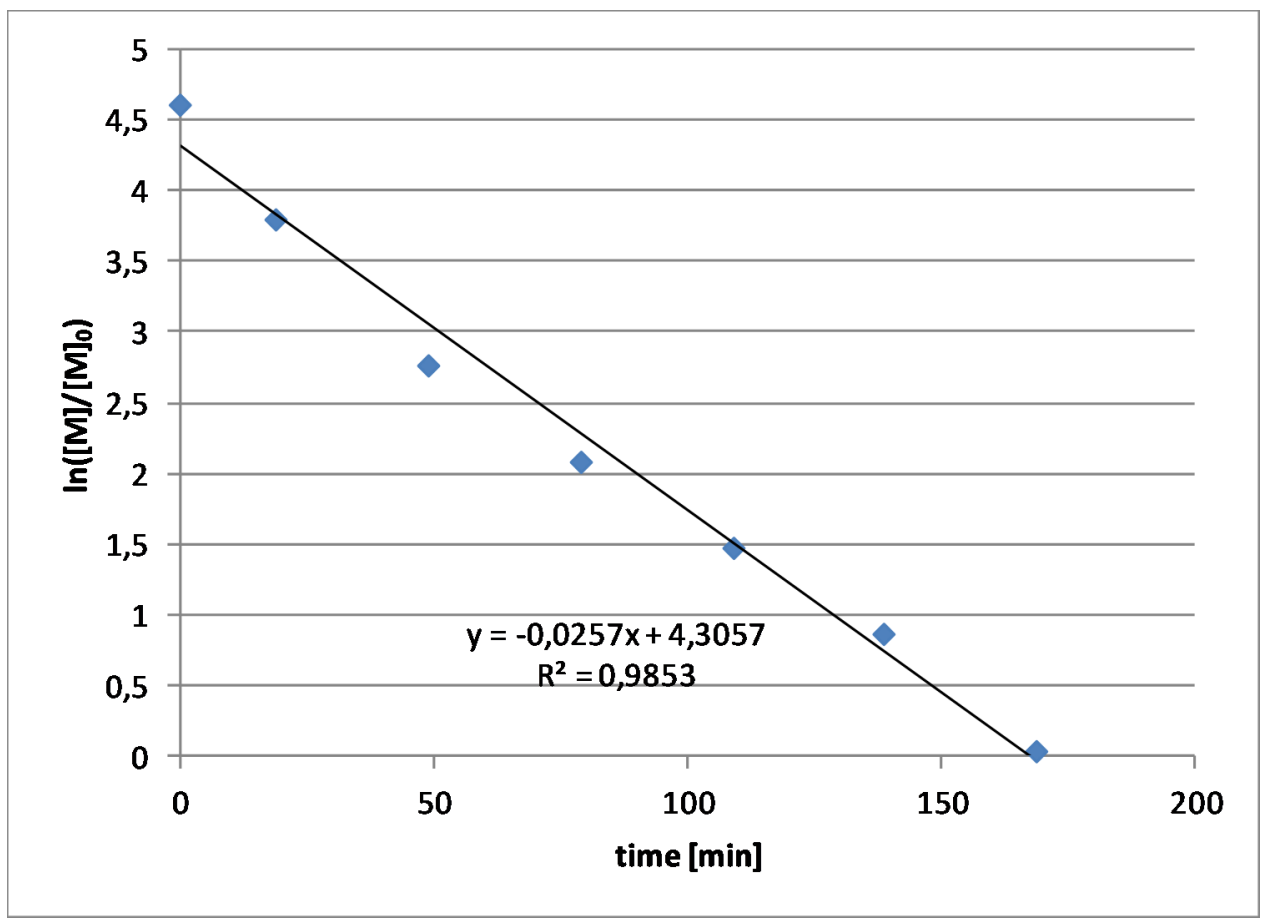

Figure S134: $1^{\text {st }}$-order plot for initiator $\mathbf{I 2 8}$ and $\mathbf{M} 1 . \mathrm{CDCl}_{3}$, r.t., $[\mathrm{M}]_{0}=0.25 \mathrm{M},[\mathrm{M}]_{0} /[\mathrm{l}]_{0}=100$. 


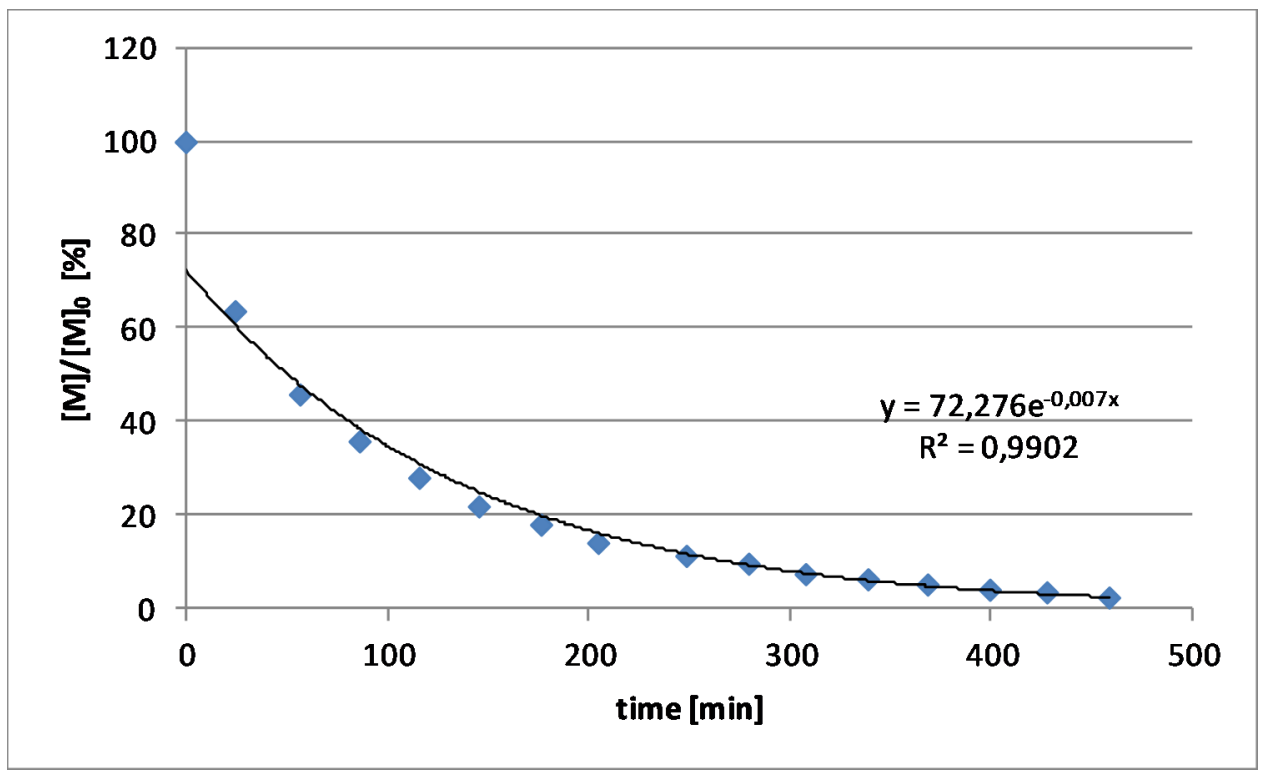

Figure S135: Monomer conversion vs. time for initiator $\mathbf{I 2 9}$ and $\mathbf{M} 1 . \mathrm{CDCl}_{3}$, r.t., $[\mathrm{M}]_{0}=0.25 \mathrm{M}$, $[\mathrm{M}]_{0} /[\mathrm{l}]_{0}=100$.

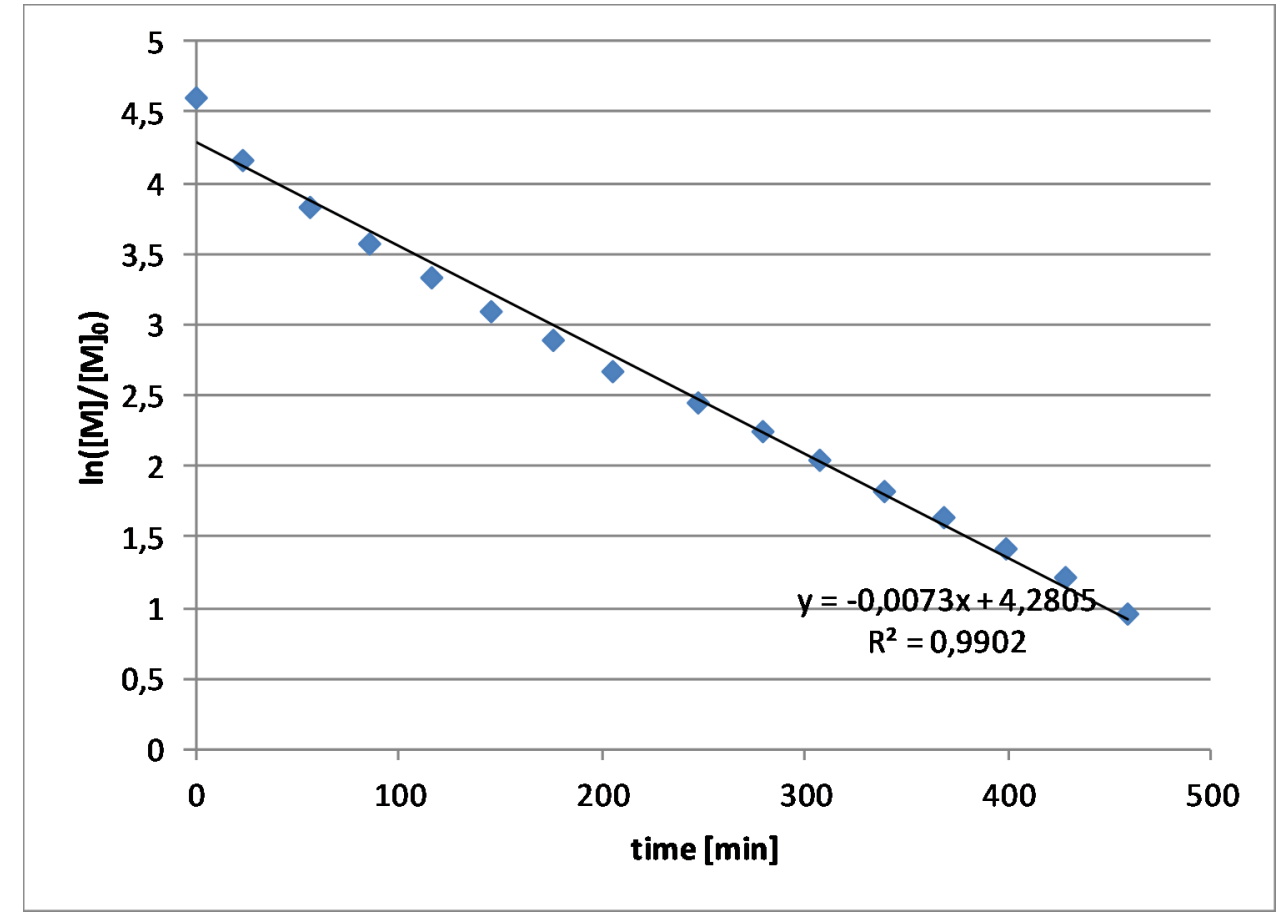

Figure S136: $1^{\text {st }}$-order plot for $\mathbf{I 2 9}$ and $\mathbf{M} 1 . \mathrm{CDCl}_{3}$, r.t., $[\mathrm{M}]_{0}=0.25 \mathrm{M},[\mathrm{M}]_{0} /[\mathrm{I}]_{0}=100$. 


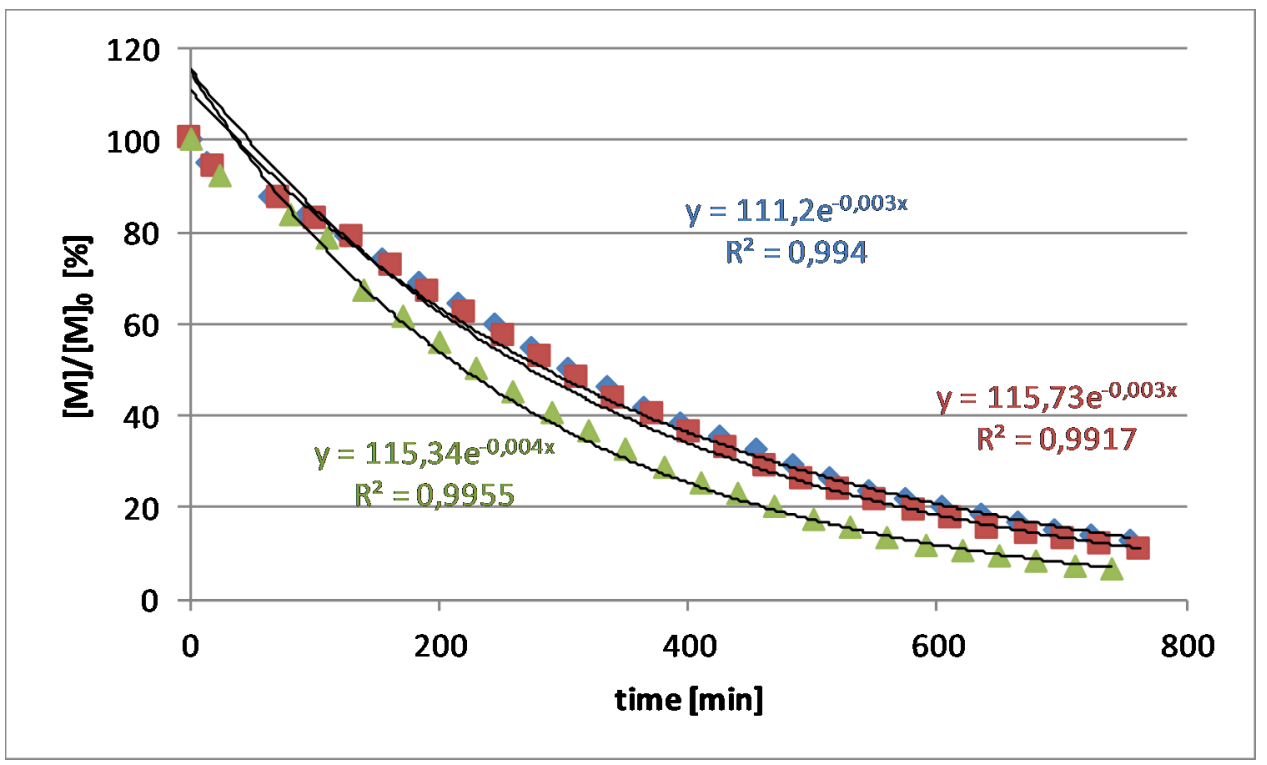

Figure S137: Monomer conversion vs. time for initiator $\mathbf{I 2 1}$ and $\mathbf{M} 1 . \mathrm{CDCl}_{3}$, r.t., $[\mathrm{M}]_{0}=0.2 \mathrm{M}$, $[\mathrm{M}]_{0} /[\mathrm{l}]_{0}=100$.

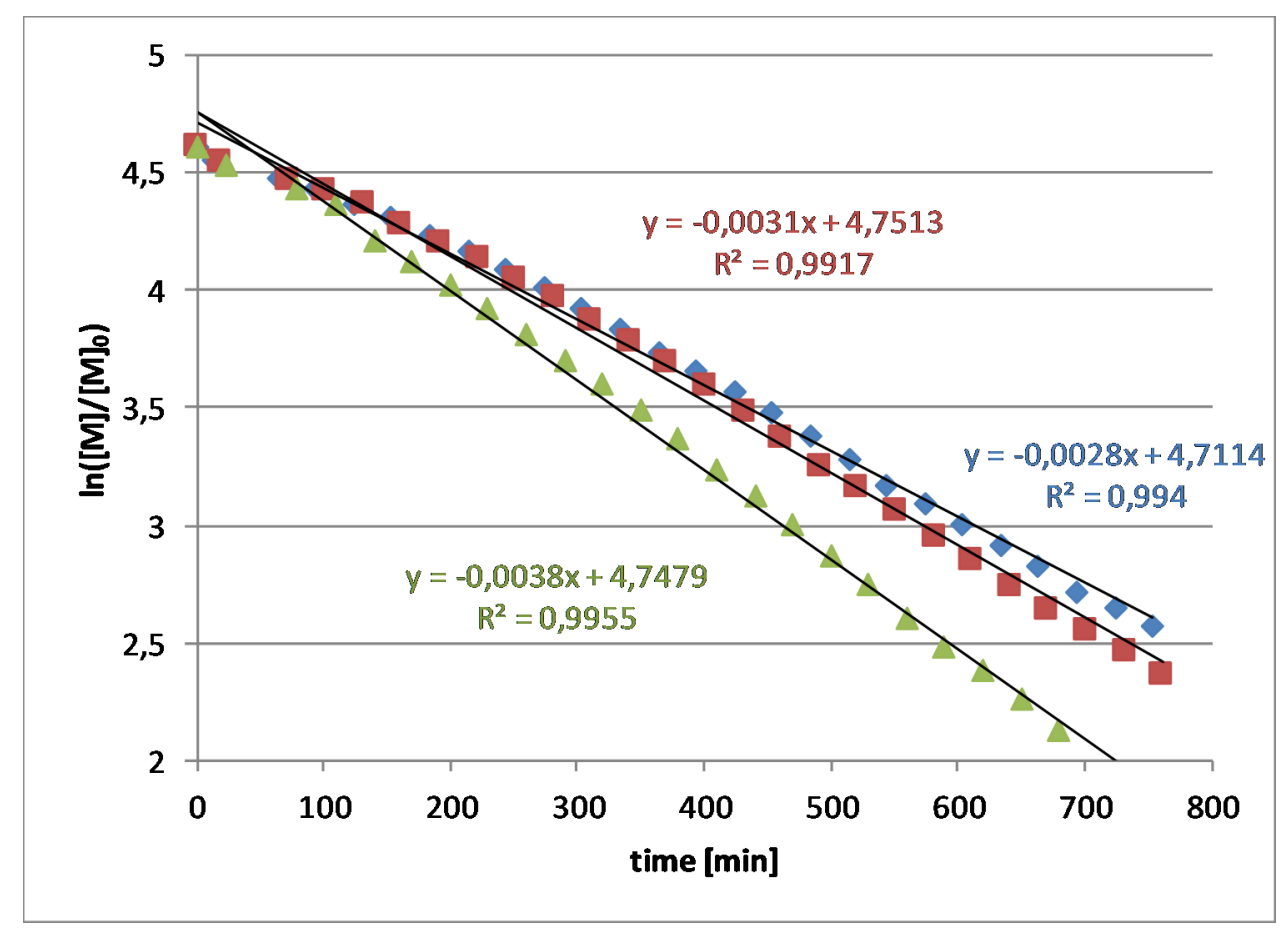

Figure S138: $1^{\text {st }}$-order plot for $\mathbf{I 2 1}$ and $\mathbf{M} 1 . \mathrm{CDCl}_{3}$, r.t., $[\mathrm{M}]_{0}=0.2 \mathrm{M}$, $[\mathrm{M}]_{0} /[]_{0} 0=100$. 


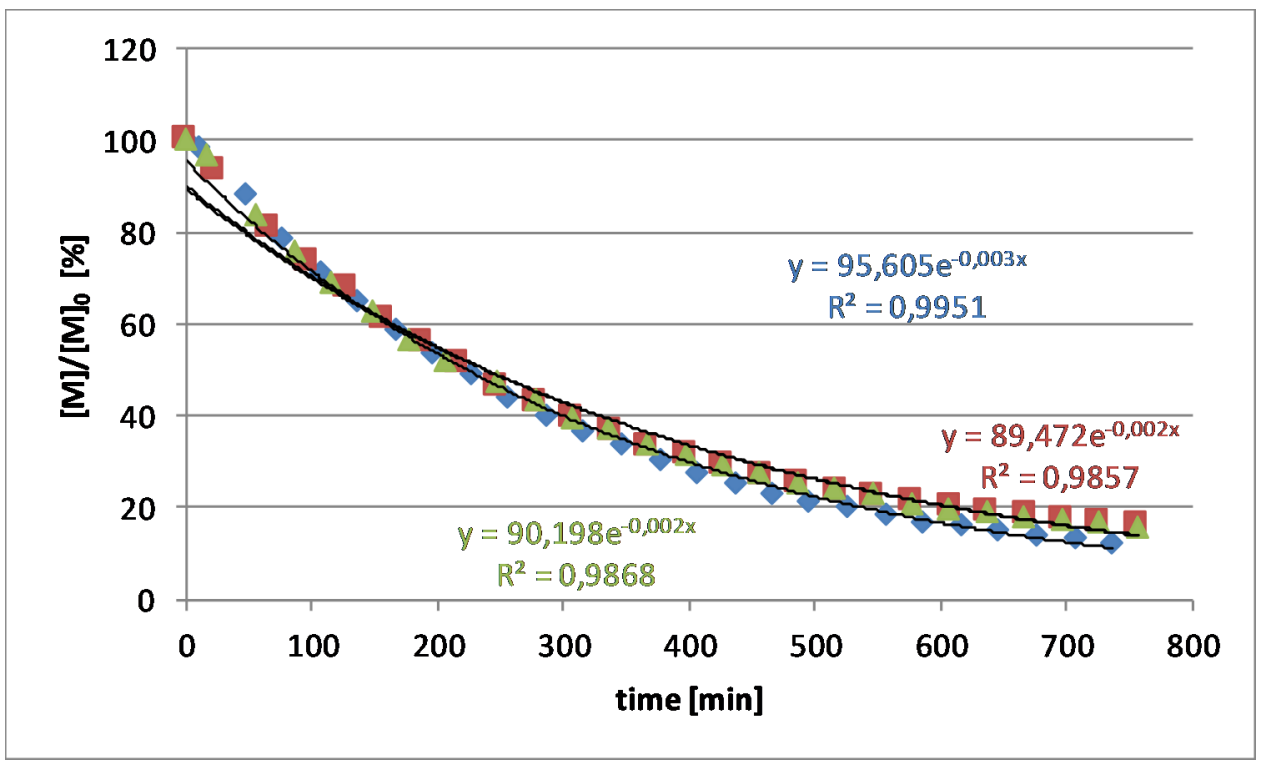

Figure S139: Monomer conversion vs. time for Initiator $\mathbf{I 2 8}$ and $\mathbf{M} 4 . \mathrm{CDCl}_{3}$, r.t., $[\mathrm{M}]_{0}=0.2 \mathrm{M}$, $[\mathrm{M}]_{0} /[\mathrm{l}]_{0}=100$.

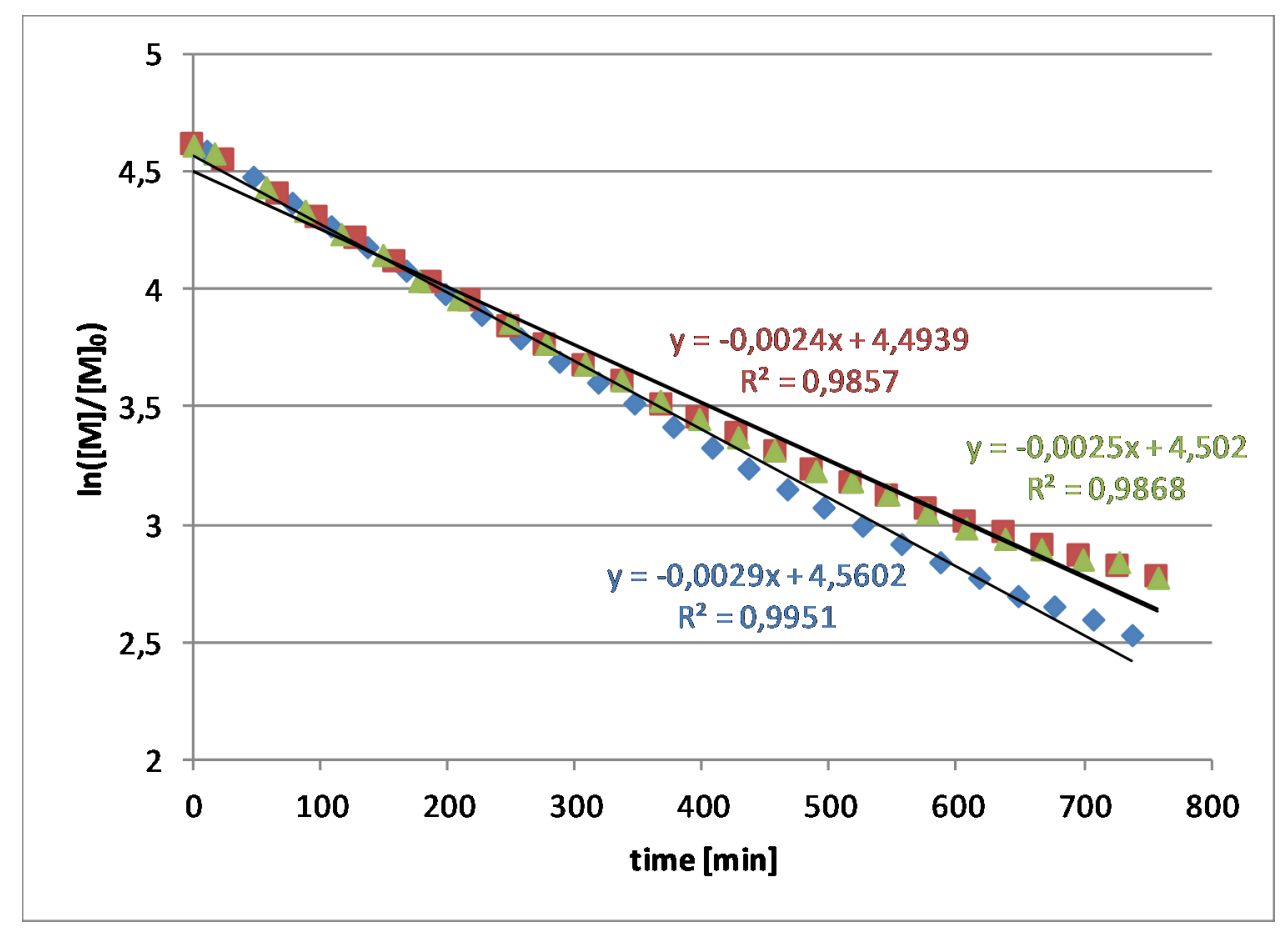

Figure S140: $1^{\text {st }}$-order plot for $\mathbf{I 2 8}$ and $\mathbf{M} 4 . \mathrm{CDCl}_{3}$, r.t., $[\mathrm{M}]_{0}=0.2 \mathrm{M},[\mathrm{M}]_{0} /[]_{0}=100$. 


\section{MALDI-ToF MS spectra}

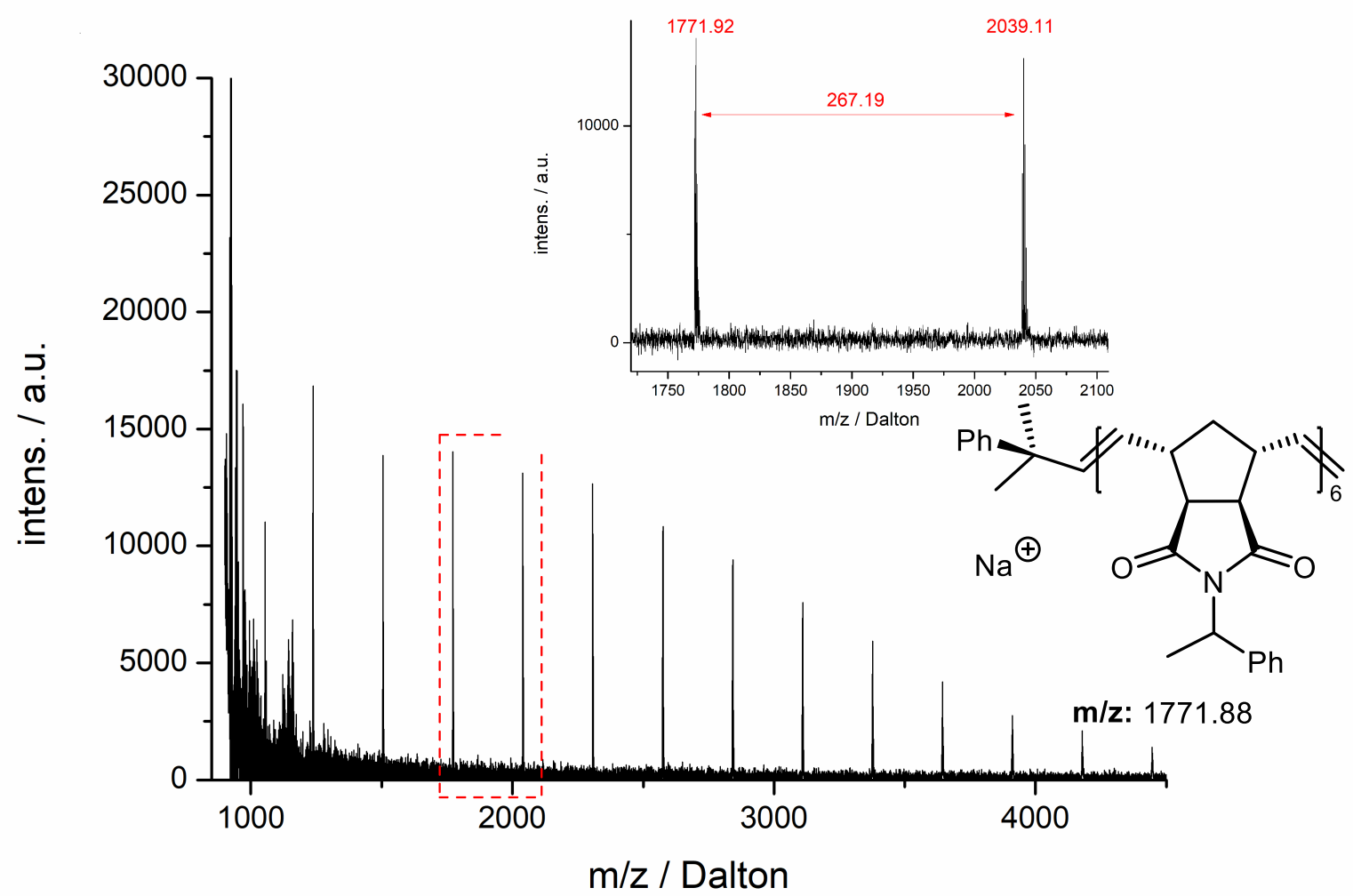

Figure S141: MALDI-ToF MS analysis of poly(M5)//21 derived from a polymerization using 15 equivalents of monomer. NaOTf was added during matrix preparation. $m / z=6^{\star} 267.33$ (repeat unit) + $14.02\left(=\mathrm{CH}_{2}\right)+132.09\left(=\mathrm{CHCMe}_{2} \mathrm{Ph}\right)+22.99(\mathrm{Na})=1771.88 ; \Delta=0.04$. 


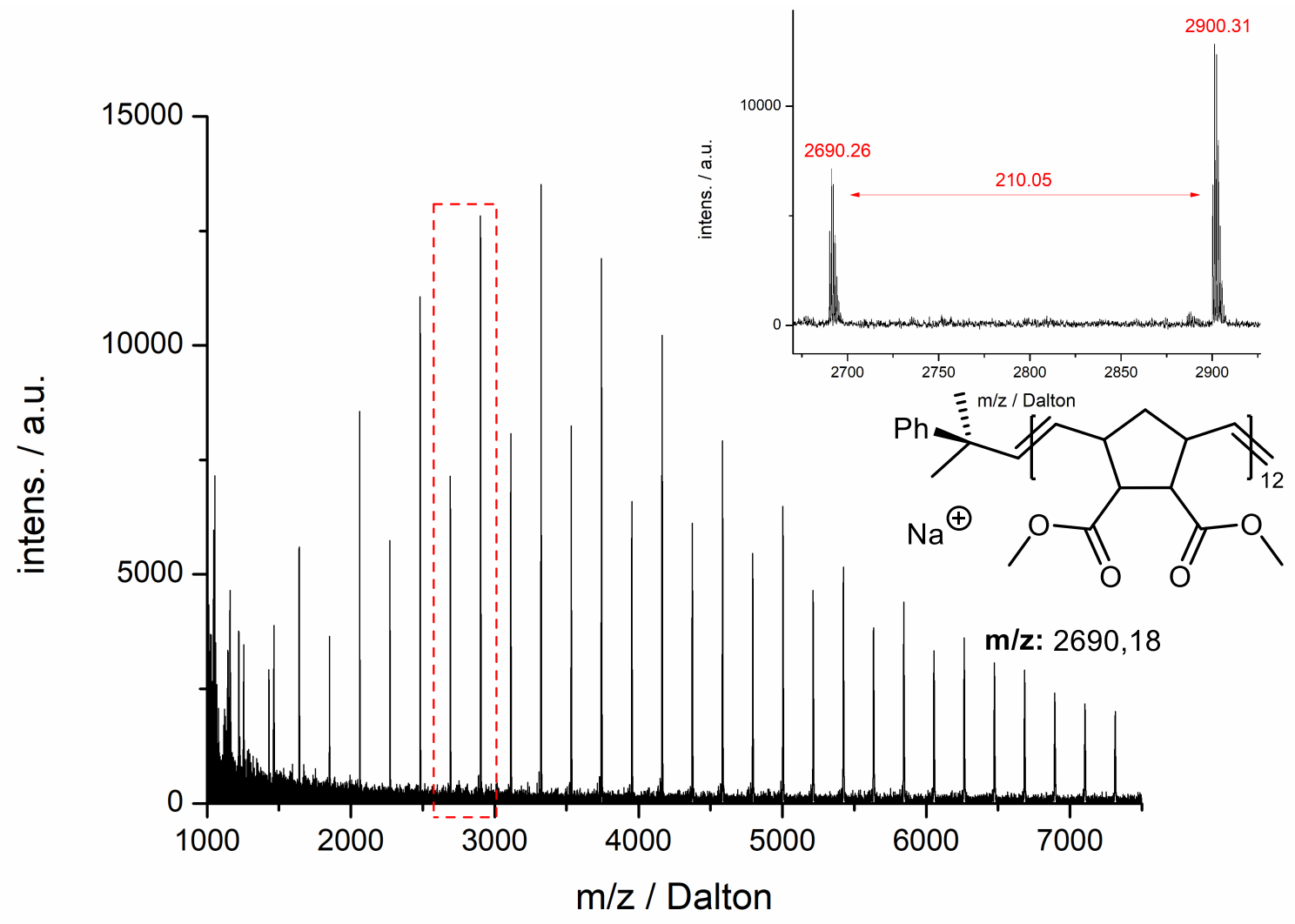

Figure S142: MALDI-ToF MS analysis of poly(M1)//21 derived from a polymerization using 15 equivalents of monomer. NaOTf was added during matrix preparation. $\mathrm{m} / \mathrm{z}=12^{*} 210.09$ (repeat unit) + $14.02\left(=\mathrm{CH}_{2}\right)+132.09\left(=\mathrm{CHCMe}_{2} \mathrm{Ph}\right)+22.99(\mathrm{Na})=2690.18 ; \Delta=0.08$.

\section{Literatur}

[1] Oskam, J. H., Fox, H. H., Yap, K. B., McConville, D. H., O`Dell, R., Lichtenstein, B. J., Schrock, R. R. Ligand variation in alkylidene complexes of the type Mo(CHR)(NR')(OR")2. J. Organomet. Chem., 1993, 459, 185-198.

[2] Schaub, T., Radius, U. Efficient C-F and C-C activation by a novel N-heterocyclic carbenenickel(0) complex. Chemistry, 2005, 11, 5024-5030.

[3] Enders, D., Breuer, K., Kallfass, U., Balensiefer, T. Preparation and Application of 1,3,4Triphenyl-4,5-dihydro-1H-1,2,4-triazol-5-ylidene, A Stable Carbene. Synthesis, 2003, 2003 , 1292-1295.

[4] Khramov, D. M., Lynch, V. M., Bielawski, C. W. N-Heterocyclic Carbene-Transition Metal Complexes: Spectroscopic and Crystallographic Analyses of m-Back-bonding Interactions. Organometallics, 2007, 26, 6042-6049.

[5] Dickie, D. A., Maclntosh, I. S., Ino, D. D., He, Q., Labeodan, O. A., Jennings, M. C., Schatte, G., Walsby, C. J., Clyburne, J. A. C. Synthesis of the bulky m-terphenyl phenol $\mathrm{Ar}^{*} \mathrm{OH}\left(\mathrm{Ar}^{*}=\right.$ $\mathrm{C} 6 \mathrm{H} 3-2,6-\mathrm{Mes} 2$, Mes = 2,4,6-trimethylphenyl) and the preparation and structural characterization of several of its metal complexes. Can. J. Chem., 2008, 86, 20-31.

[6] Malcolmson, S. J., Meek, S. J., Sattely, E. S., Schrock, R. R., Hoveyda, A. H. Highly efficient molybdenum-based catalysts for enantioselective alkene metathesis. Nature, 2008, 456, 933937. 